\author{
UNIVERSIDADE DE SÃO PAULO \\ Faculdade de Filosofia, Letras e Ciências Humanas \\ Departamento de Linguística \\ Programa de Pós-Graduação em Semiótica e Linguística Geral
}

\author{
JÉSSICA CLEMENTINO DA COSTA
}

\title{
A estrutura argumental da língua Dâw
}




\author{
UNIVERSIDADE DE SÃO PAULO \\ Faculdade de Filosofia, Letras e Ciências Humanas \\ Departamento de Linguística \\ Programa de Pós-Graduação em Semiótica e Linguística Geral
}

\title{
A estrutura argumental da língua Dâw
}

Jéssica Clementino da Costa

Orientadora: $\operatorname{Prof}^{\mathrm{a}} \mathrm{Dr}^{\mathrm{a}}$ Luciana Raccanello Storto

Dissertação de mestrado apresentada ao programa de Pós-Graduação em Semiótica e Linguística Geral da Faculdade de Filosofia, Letras e Ciências Humanas da Universidade de São Paulo como requisito para obtenção do título de mestre em Letras.

Versão corrigida

De acordo,

$\operatorname{Prof}^{\mathrm{a}} \mathrm{Dr}^{\mathrm{a}}$ Luciana Raccanello Storto 


\section{Folha de aprovação}

Autora: $\quad$ COSTA, J,C. (Jéssica Clementino da Costa)

Título: $\quad$ A estrutura argumental da língua Dâw

Dissertação de mestrado apresentada ao programa de Pós-Graduação em Semiótica e Linguística Geral da Faculdade de Filosofia, Letras e Ciências Humanas da Universidade de São Paulo como requisito para obtenção do título de mestre sob orientação da Prof ${ }^{\underline{a}} \mathrm{Dr}^{\mathrm{a}}$ Luciana Raccanello Storto.

Aprovado em:

Banca Examinadora

Prof ${ }^{\text {a }}$ Dr - Luciana Raccanello Storto

(Presidente)

Prof ${ }^{\mathrm{a}}$ Drª Esmeralda Vailati Negrão

(Titular)

Prof ${ }^{\mathrm{a}}$ Dr$\stackrel{\text { a }}{ }$ Kristine Sue Stenzel

(Titular)

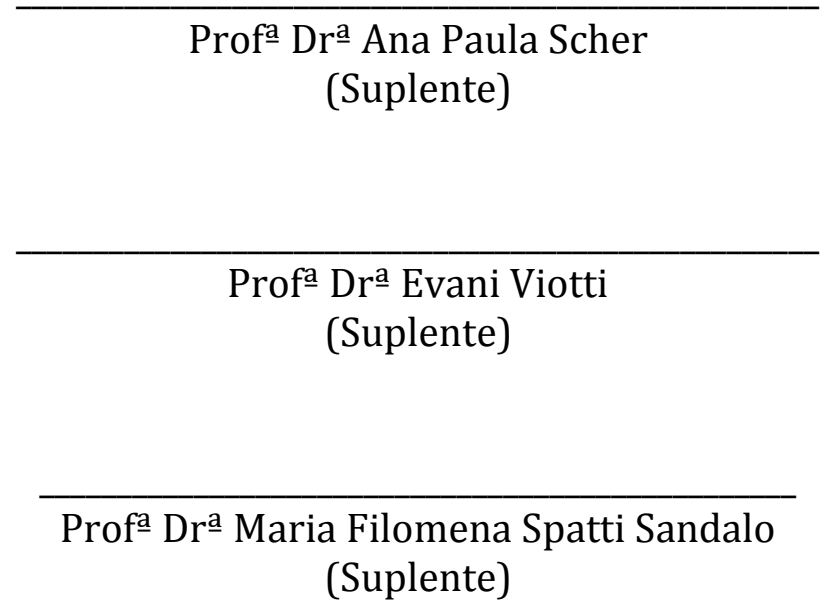


Esta pesquisa foi apoiada pela Fundação de Amparo à pesquisa do Estado de São Paulo (FAPESP), Processo 2011/16168-2.

Os trabalhos de campo realizados foram financiados pelo(a):

- Programa de Pós-Graduação em Semiótica e Linguística Geral do Departamento de Linguística da USP - CAPES/PROEX;

- ELDP (concessão número SG0208).

- Fundação de Amparo à pesquisa do Estado de São Paulo (FAPESP). 
Ao povo Dâw,

Que me ensinou outro modo de vida.

Aos meus pais, Solange e José Maria,

Que me deram a vida.

A Wallace Bernando,

Que é a minha vida. 


\section{AGRADECIMENTOS}

Primeiramente, agradeço à minha família, meus pais, Solange e José Maria, aos meus pais-avós Julita e Manoel, aos meus irmãos Évelyn e Jaison, e às minhas cunhadas-irmãs Fabiana e Leli. Sem dúvida, esse trabalho não teria sido realizado se não fossem vocês em minha vida. Cada palavra, gesto e sentimento foram imprescindíveis nesses anos de pesquisa e em toda minha trajetória de vida. Devo a vocês cada batalha vencida.

Ao meu noivo Wallace Bernardo, que é a minha força e coragem. Obrigada por me fazer verdadeiramente feliz. Aos meus sogros Katia e Luís Carlos por todo amor e dedicação em todos os momentos.

À família Jaguaré Patrícia Borges e Janayna Carvalho, que de forma tão singela me proporcionaram momentos de muita alegria, força e amizade. O lar (e não república!) que construímos nesses quase dois anos de convivência foram vitais para o meu amadurecimento. Vocês são minhas amigas e minhas irmãs.

Aos amigos de todos os tempos Júlia Pontes, Julia Crudis, Stela Danna, Bruna Polachini, Renan Viani e Bianca Fraga. Vocês são peças importantes e elementos fundamentais da minha jornada (sem falar dos encontros fenomenais na casa da Ju, claro!).

À minha amiga Érica Bertolon que me incentivou a estudar línguas indígenas e me mostrou que eu era capaz.

Aos queridíssimos Natalia Marcelli, Natália Rogers, Camila Oliveira, Marcus Martins, Joana Franco, Marília Vieira, Renata Carneiro, Lucas Lopes, Fernanda Rosa, Lygia Rachel, Bárbara Macedo e Rafael Ireno.

À minha orientadora Luciana Storto, que sempre foi muito ética durante a realização dessa pesquisa. Considero-me com muita sorte de poder ter realizado meus trabalhos de campo ao seu lado. Pude aprender muito não só sobre linguística, mas também sobre a vida, o que me faz considera-la mais do que uma orientadora, e sim uma amiga.

À professora Patience Epps, que coordenou o projeto de documentação da língua Dâw e me deu a oportunidade de pesquisar e aprender muito durante o todo o trabalho de documentação. 
Ao companheiro de campo Wallace Andrade, que esteve comigo durante todos os trabalhos de campo. Sua companhia nessas viagens foi vital para a realização desse trabalho (porque amigo é aquele que foca!).

Ao povo Dâw, que me ensinou (e me deu) um novo olhar sobre a vida. Agradeço especialmente ao Roberto, Mateus, Silia, Tatiane, Valteir, Pedro e Jonas, colaboradores do projeto de documentação. À Auxiliadora, Francisco, Rose e Elisandro que tornaram nossa estada possível durante os três trabalhos de campo realizados.

Aos companheiros indigenistas Karin Vivanco, Ivan Rocha, Carolina Alves, Lorena Orjuela, Maurício Carvalho, Lucas Barboza, Clariana Assis, Luciana SanchesMendes, Lara Frutos e Talita Rodrigues.

Aos integrantes do GREMD, Vitor Nóbrega, Rafael Minussi, Paula Armelin, Aline Takahira, Julio Barbosa, Indaiá Bassani, que me acolheram durante um período dessa pesquisa nas suas reuniões semanais.

Aos professores do DL, especialmente ao Waldir Beividas e Marcos Lopes, que me incentivaram, desde os primórdios de Elementos de Linguística, a trilhar pelos caminhos dos estudos linguísticos. Às professoras Esmeralda Negrão e a Ana Scher, pelos comentários valiosíssimos no exame de qualificação deste trabalho. Aos professores Marcelo Barra e Evani Viotti, que foram meus supervisores no estágio PAE. Aos professores Ronald Beline (chefe do DL) e Olga Coelho Sansone (chefe da pósgraduação do DL).

Aos secretários do DL Robson, Larissa, Érica e Ben Hur, que fazem seu trabalho com muita dedicação e competência.

Às representantes discentes Daniela Bracchi e Talita Ewald.

À FAPESP (processo número 2011/16168-2) pela bolsa concedida durante a pesquisa de mestrado.

E por fim, e não menos importante, à força criadora de todo o universo que nomeamos Deus e ao meu mentor espiritual por simplesmente tudo que acontece nessa jornada de vida. 
Abug dâw teg, bug dâw dô' pâad 'a' yẽew mãy dâw teg bug dâw yaam Quando a gente faz dabucuri, a gente tira cunuri; isso é bom para nós, a gente dança.

Abug dâw yum rũr, aa yẽew pưd yêd dabukuri id nêe
Aí a gente canta; o dabucuri é bom para nós.

Aa ãr gostaal 'a' dâw teg bug dâw dôo nãak, wiim, mũu yẽew mãay dâw teg â' Eu gosto quando a gente faz dabucuri; aí a gente tira açaí, bacaba; é bom fazer dabucuri de ucuqui

Agê' id xaay nũkêd id kutura id teg id kutura rẽd Isso é nossa cultura; desde antigamente nós fazemos dabucuri

Id dâw, dâr kutura nũkwaar dâr kutura id teg 'a' A cultura do nosso povo, a cultura dos antigos na qual nós fazemos dabucuri.

Canto dabucuri - Cantado por D. Deolinda (Comunidade Waruá, julho 2013) 


\section{RESUMO}

COSTA, Jéssica Clementino da. A estrutura argumental da língua Dâw. 2014. 286f. Dissertação (Mestrado) - Faculdade de Filosofia, Letras e Ciências Humanas, Universidade de São Paulo, São Paulo, 2014.

Esta dissertação descreve e analisa a estrutura argumental e as classes verbais da língua Dâw (família Nadahup, Amazonas). Estudamos os verbos dessa língua do ponto de vista semântico e sintático, identificando classes e subclasses de acordo com o comportamento morfossintático das raízes verbais. Além disso, avaliamos as hipóteses descritivas e explicativas das classes verbais identificadas por Martins (2004), primeira pesquisadora a abordar a morfossintaxe Dâw. Nosso arcabouço teórico é a teoria de estrutura argumental desenvolvida por Hale \& Keyser (2002), que propõe uma análise da sintaxe e da semântica dos itens lexicais por meio da estrutura argumental - sistema de relações estruturais estabelecidas entre o núcleo e seus argumentos, dentro de estruturas sintáticas projetadas pelo próprio núcleo. Por meio de testes linguísticos variados, incluindo alternância de valência e julgamento de (a)gramaticalidade, reclassificamos as nove classes verbais identificadas por Martins (2004) em três classes de acordo com a valência do verbo: classe dos verbos intransitivos, classe dos verbos transitivos e classe dos verbos bitransitivos. Martins (2004) afirma que, na sentença, os verbos podem mudar de tom devido à presença de um morfema tonal transitivizador ou intransitivizador. Contudo, mostramos neste trabalho que o sistema tonal da língua, no nível da sentença, é previsível. Desse modo, independentemente do processo de aumento de valência envolvido, percebemos que a mudança tonal dos verbos decorre devido ao fraseamento fonológico das sentenças. Quanto ao processo de transitivização, este identificou subclasses de verbos intransitivos: verbos alternantes e verbos nãoalternantes. As restrições de alternância devem-se à estrutura argumental de cada tipo verbal. No caso dos verbos intransitivos alternantes ou inacusativos, observamos que eles são formados a partir de estrutura diádica composta, que projeta um especificador interno e um complemento, o que lhe permite alternar entre uma forma intransitiva e transitiva. No caso dos verbos não-alternantes encontramos três padrões: verbos denominais e inergativos, formados a partir de uma estrutura argumental monádica (que não projeta especificador interno), o que impede a alternância; verbos inacusativos nãoalternantes, formados a partir de uma estrutura monádica que toma como complemento uma estrutura diádica básica - verbos desse tipo não alternam, pois eles não são formados por uma estrutura diádica, mas contêm tal estrutura; e verbos 'deadjetivais', formados a partir de uma cópula que toma como complemento um adjetivo. Uma vez que raiz e núcleo verbal possuem conteúdo fonológico pleno (não vazio), não é possível fazer conflation entre núcleo e raiz, o que impede que o predicado verbal seja formado. Essa estrutura explica a agramaticalidade desses verbos frente ao processo de transitivização automática. Também testamos a sintaxe e a semântica da intransitivização (construções incoativas, voz passiva, reflexiva e média). De modo geral, percebemos que não há morfologia específica para a construção de sentenças médias, incoativas ou anticausativas. Não existem passivas em Dâw; no lugar desta voz, os falantes produzem sentenças incoativas ou com o sujeito subespecificado. As sentenças reflexivas são geradas por meio de pronomes reflexivos na posição de objeto da sentença. Por fim, vimos que objetos diretos de sentenças transitivas são marcados pelo morfema \{-üty'\} analisados por nós como MDO. Sua aplicação está condicionada a restrições semânticas de definitude e animacidade.

Palavras-Chave: Dâw; classes verbais; estrutura argumental; morfossintaxe verbal 


\section{ABSTRACT}

COSTA, Jéssica Clementino da. The argument structure of the Dâw language. 2014. 286f. Thesis (Masters) - Faculty of Philosophy, Languages and Literature, and Human Sciences, University of São Paulo, São Paulo, Brazil, 2014.

This thesis describes and analyzes the argument structure and verbal classes of the Dâw language (Nadahup family, Amazon). We studied the verbs of that language from the semantic and syntactic perspective, identifying classes and subclasses according to the morphosyntactic behavior of verbal roots. Furthermore, we evaluated the descriptive and explanatory hypotheses of verb classes identified by Martins (2004), the first researcher to address Dâw morphosyntax. Our theoretical framework is the theory of argument structure developed by Hale \& Keyser (2002), which proposes an analysis of the syntax and semantics of lexical items by means of the argument structure - the pattern of structural relations between the head and its arguments within syntactical structures projected by the head itself. Through various language tests, including verbal valency alternation and judgment of (a)grammaticality, we reclassified the nine verb classes identified by Martins (2004) into three classes according to the verbal valency: the classes of intransitive verbs, transitive verbs and bitransitive verbs. Martins (2004) states that, in the sentence, the verbs may change in tone due to the presence of a transitivizing or intransitivizing tonal morpheme. However, we show in this paper that the tonal system of the language is predictable at the sentence level. Thus, regardless of the valency-increasing process involved, we realized that the tonal change of verbs arises due to the phonological phrasing of sentences. Regarding the transitivization process, subclasses of intransitive verbs were identified: alternating and non-alternating verbs. The restrictions on alternation are due to the argument structure of each verb type. In the case of unaccusative or alternating intransitive verbs, we observed that they are formed from a composite dyadic structure, projecting an internal specifier and a complement, which allows them to switch between intransitive and transitive forms. In the case of non-alternating verbs we found three patterns: denominal and unergative verbs, based on a monadic argument structure (that does not project internal specifier) that prevents alternation; non-alternating unaccusative verbs based on a monadic structure that takes a basic dyadic structure as a complement - verbs of this type do not alternate because they are not formed by a dyadic structure, but contain such a structure - and "deadjectival verbs", formed from a copular verb that takes an adjective as a complement. Since the root and verbal head have full (non-empty) phonological content, no conflation is possible between head and root, which prevents the formation of the verbal predicate. This structure explains the agrammaticality of these verbs with regard to the automatic transitivization process. We also tested the syntax and semantics of intransitivization (inchoative constructions, passive, reflexive and middle voices). In general, we found that there is no specific morphology for constructing middle, inchoative or anticausative sentences. There are no passives in Dâw; in place of this voice, the speakers form sentences that are inchoative or have a subspecified subject. Reflexive sentences are created using reflexive pronouns in the position of the object of the sentence. Finally, we found that direct objects of transitive sentences are marked by the $\{-\tilde{u} u y '\}$ morpheme analyzed by us as DOM. Its use is subject to semantic constraints of definiteness and animacy.

Keywords: Dâw; verb classes; argument structure; verbal morphosyntax 


\section{Glosas}

1SG

2SG

3SG

1SG.OBL

1SG.POS

3SG.POS

ACC

AFET

ASPC

AUM

CAUS

COL

COMTI

$\mathrm{CONJ}$

cop

DECL

DIR

DIST

DUR

FRUST

FUT

GEN

HABII

IMP

IND

INFR2

INSTR

Intensif.

INTRV

INTSI

INTSII $1^{\mathrm{a}}$ pessoa do singular

2 a pessoa do singular

3 a pessoa singular

1a pessoa do singular oblíquo

$1^{\mathrm{a}}$ pessoa do singular possessivo

$3^{\mathrm{a}}$ pessoa do singular possessivo

Acusativo

Caso afetado

Aspecto

Aumentador

Causativo

Coletivo

Comitativo I

Conjunção

cópula

Declarativo

Direcional

Distributivo

Durativo

Frustâneo

Futuro

Genitivo

Habitual I

Imperativo

Indefinido

Inferencial 2 (evidencial)

Instrumento

Ser intensificado

Intransitivizador

Intensivo 1

Intensivo 2 


\begin{tabular}{|c|c|}
\hline ITER & Iterativo \\
\hline ITG & Intangível \\
\hline MDO & Marcação Diferencial de Objeto \\
\hline MSC & Morfema de ênfase para nomes masculinos \\
\hline Mov & Movimentar \\
\hline MV & Morfema de Valência \\
\hline NEG & Negação \\
\hline NP & Nome próprio \\
\hline OBJ & Objeto \\
\hline OBL & Oblíquo \\
\hline PAS & Passado \\
\hline PERFCI & Perfectivo 1 \\
\hline PERFCII & Perfectivo 2 \\
\hline PERFCIII & Perfectivo 3 \\
\hline PL & Plural \\
\hline PLZ & Pluralizador \\
\hline POSS & Possessivo \\
\hline PONT & Pontual \\
\hline RECIP & Recipiente \\
\hline$-\mathrm{REF}$ & Reforço \\
\hline TEL & Télico \\
\hline TOT & Totalizador \\
\hline TRANV & Transitivizador \\
\hline
\end{tabular}




\section{Lista de mapas}

Seções

Página

Mapa 1.0: Área tradicional do povo Dâw

Mapa 1.1: Localização das línguas Nadahup

\section{Lista de figuras}

Seções

Figura 1.1: Família Nadahup: formação e correspondências

Página

Figura 1.2: Layout do banco de dados Dâw no programa FLEx

Figura 1.3: Layout do ELAN

33

Figura 3.0: Escala de dinamicidade e classes verbais

Figura 7.0: Exemplo de objeto humano animado

Figura 7.1: Exemplo de objeto animal animado

Figura 7.2: Exemplo de objeto inanimado 


\section{Lista de tabelas e quadros}

Seções

Quadro 1.0: Fonemas consonantais e ortografia Dâw

Quadro 1.1: Fonemas vocálicos e ortografia Dâw

Tabela 1.0: Trabalhos de campo realizados durante a pesquisa

Tabela 1.1: Lista com todos os verbos testados

Tabela 2.0: Verbos bitransitivos testados

Tabela 2.1: Protocolo de elicitação de construções transitivas 53

Tabela 2.2: Protocolo de elicitação de construções bitransitivas 55

Tabela 3.0: Verbos ativos intransitivos $\quad 57$

Tabela 3.1: Verbos ativos transitivos 58

Tabela 3.2: Verbos ativos bitransitivos $\quad 59$

Tabela 3.3: Verbos de processo $\quad 59$

Tabela 3.4: Verbos de processo que expressam fenômeno da natureza $\quad 60$

Tabela 3.5: Verbos equativos existenciais $\quad 60$

Tabela 3.6: Verbos equativos identificacionais $\quad 60$

Tabela 3.7: Verbos de verbos estativos atributivos $\quad 61$

Tabela 3.8: Verbos de verbos estativos qualificativos 61

Tabela 3.9: Verbos de verbos estativos posicionais 61

Tabela 3.10: Síntese dos parâmetros que classificam as classes verbais $\quad 62$ em Dâw

Tabela 3.11. Classes verbais reanalisadas de acordo com o critério de 63 valência

Tabela 3.12: Verbos intransitivos testados 64

Tabela 3.13: Verbos estativos testados 68

Tabela 3.14: Verbos denominais testados $\quad 72$

Tabela 3.15: Lista de adjetivos testados $\quad 74$

Tabela 3.16: Verbos intransitivos e transitivos testados com vários tipos $\quad 76$

de cópulas

Tabela 3.17: Verbos intransitivos testados nas construções reflexivas 83

Tabela 3.18: Verbos transitivos testados 86

Tabela 3.19: Verbos intransitivos e transitivos testados com os aspectos $\quad 90$ xâd e dâr

Tabela 3.20: Verbos bitransitivos testados

Tabela 4.0: Verbos intransitivos testados

Tabela 4.1: Protocolo de elicitação de sentenças intransitivas 105

Tabela 4.2: Protocolo de elicitação de sentenças transitivizadas e 106 causativizadas

Tabela 4.3. Padrões tonais no nível da sentença (Storto, Costa e Andrade, 107 em elaboração)

Tabela 5.0: Verbos intransitivos testados

Tabela 5.1. Verbos intransitivos alternantes 133

Tabela 5.2: Verbos intransitivos não-alternantes 134

Tabela 5.3: Verbos intransitivos com sujeito agente e denominais não- 148 alternantes

Tabela 5.4: Verbos inacusativos que não alternam 151

Tabela 5.5. Verbos deadjetivais não alternantes 155

Tabela 5.6: Verbos intransitivos e transitivos testados com dôo 158 
Tabela 6.0. Verbos transitivos testados

Tabela 7.0: Contextos de marcação do objeto por $\{$ dìh $\}$ em Yuhup

Tabela 7.1: Protocolo de elicitação com controle situacional das sentenças contexto definido (familiar)

$\begin{array}{llll}\text { Tabela 7.2: Protocolo de elicitação com controle situacional das } 198 & \end{array}$ sentenças contexto definido e não-específico

Tabela 7.3: Protocolo de elicitação com controle situacional das 199 sentenças contexto indefinido

Tabela 7.4: Protocolo de elicitação com colocação de figuras e explanação de ações

Tabela 7.5: Resultados dos testes de colocação de figuras e explanação de ações

208

Tabela 7.6: Protocolo de elicitação do teste de (a)gramaticalidade do uso de $\{$-ũuy'\} com sentenças bitransitivas 
Seções

Página

Capítulo 1: Introdução

19

1.0. Objetivos do projeto de pesquisa $\quad 19$

1.1. O povo, a língua e a família linguística 19

1.1.1. O povo 19

1.1.2. A língua $\quad 21$

1.1.3. A ortografia $\quad 23$

1.1.4. A família linguística $\quad 25$

1.2. Trabalho de Campo $\quad 27$

1.3. Corpus 29

1.4. Documentation of Dâw, a Nadahup language of Brazil 32

1.5. Estrutura do trabalho $\quad 35$

Capítulo 2: Metodologia do trabalho de campo 36

$\begin{array}{ll}\text { 2.0. Introdução } & 36\end{array}$

2.1. Visão geral da metodologia empregada na pesquisa 37

2.2. Visão detalhada da metodologia empregada na pesquisa 39

2.2.1. Fase 1: compilação e organização dos verbos 39

2.2.2. Fase 2: realização de testes linguísticos 39

2.2.2.1. Teste de produção de sentenças em Dâw 39

Conjunto 1 - verbos monoargumentais 40

Conjunto 2 - verbos biargumentais $\quad 45$

Conjunto 3 - verbos com mais de dois argumentos $\quad 48$

2.2.2.2. Teste de (a)gramaticalidade $\quad 49$

Conjunto 1 - verbos monoargumentais 49

Conjunto 2 - verbos biargumentais $\quad 52$

Conjunto 3 - verbos com mais de dois argumentos $\quad 54$

2.3. Síntese do capítulo

Capítulo 3: As classes verbais da língua Dâw 56

3.0. Introdução 56

3.1. As classes verbais da língua Dâw segundo Martins (2004) 57

3.2. Reanalisando as classes verbais em Dâw 63

3.2.1. Classe dos verbos intransitivos 64

3.2.2. Classe dos verbos transitivos $\quad 85$

3.2.3. Classe dos verbos bitransitivos $\quad 94$

3.3. Síntese do capítulo $\quad 96$

Capítulo 4: O sistema tonal da língua Dâw 98

4.0. Introdução 98

4.1. O sistema tonal da língua Dâw segundo Martins (2004) 99

4.2. O processo de transitivização segundo Martins (2004) 100

4.3. 0 processo de intransitivização segundo Martins (2004) 102

4.4. O sistema tonal da língua Dâw (Storto, Costa e Andrade, em 103 elaboração)

4.4.1. Reanalisando a transitivização em Dâw 
4.5. Síntese do capítulo 126

Capítulo 5: Processos de aumento de valência 128

$\begin{array}{ll}\text { 5.0. Introdução } & 128\end{array}$

5.1. Transitivizaçaoo em Dâw 129

5.1.1. A teoria de Hale \& Keyser (2002) 137

5.1.1.1. Estrutura Monádica 138

5.1.1.2. Estrutura diádica composta $\quad 140$

5.1.1.3. Estrutura diádica básica 142

5.1.2. Diálogo entre os dados do da língua Dâw e a teoria de 145

Hale \& Kayser (2002)

5.1.2.1. A subclasse dos verbos alternantes ou $\quad 145$ inacusativa

5.1.2.2. A subclasse dos verbos não-alternantes $\quad 147$

5.2. Causativização em Dâw 157

5.2.1. Causativização com verbos intransitivos $\quad 160$

5.2.2. Causativização com verbos transitivos $\quad 163$

5.4. Síntese do capítulo 164

Capítulo 6: Processos de redução de valência 166

6.0. Introdução 166

6.1. Os processos de redução de valência descritos por Martins 166 (2004)

6.1.1. A formação de verbos intransitivos e médios em Dâw 166

6.1.2. Voz reflexiva em Dâw 168

6.1.3. Voz passiva em Dâw 169

6.2. Definindo os processos de intransitivização 170

6.3. Reanalisando os processo de intransitivização em Dâw 177

6.3.1. Construções reflexivas 178

6.3.2. Construções médias e incoativas (anticausativas) 179

6.3.2. Construção passiva 181

6.4. Síntese do capítulo 183

Capítulo 7: A marcação de objeto em Dâw 184

7.0. Introdução 184

7.1. 0 morfema de caso afetado $\{$-ũuy' $\}$

7.2. Definindo MDO 188

7.3. MDO nas línguas Nadahup - Yuhup e Hup 191

7.4. Estudo do uso de $\{$-ũuy'\} em Dâw 195

7.4.1. Elicitação de dados $\quad 195$

7.5. Redefinindo caso afetado em Dâw $\quad 210$

7.6. Síntese do capítulo 211

$\begin{array}{lr}\text { Considerações Finais } & 212\end{array}$

Referências Bibliográficas $\quad 215$ 
Anexo 1

Anexo 2

259

Anexo 3 


\subsection{Objetivos do projeto de pesquisa}

Nesse trabalho, estudamos as classes verbais da língua Dâw do ponto de vista semântico e sintático, identificando classes e subclasses de acordo com o comportamento morfossintático das raízes verbais ${ }^{1}$. Desse objetivo, decorre a avaliação das hipóteses descritivas e explicativas das classes verbais identificadas por Martins (2004), primeira pesquisadora a abordar a morfossintaxe da língua Dâw.

Neste capítulo introdutório, trazemos breves informações sobre o povo e a língua Dâw e a família linguística Nadahup, além de descrever os três trabalhos de campo realizados em fevereiro de 2013, julho de 2013 e janeiro-fevereiro de 2014; e o trabalho de documentação da língua e cultura Dâw realizado paralelamente a este trabalho.

\subsection{0 povo, a língua e a família linguística}

\subsubsection{0 povo}

O povo Dâw é formado por cento e vinte e sete pessoas (Auxiliadora, representante da comunidade, comunicação oral; Martins, V. $2013^{2}$, comunicação oral). Esse povo habita uma região conhecida como Waruá, no município de São Gabriel da Cachoeira, na região do Alto Rio Negro, no estado do Amazonas. Nessa região, ainda convivem com os Dâw mais duas grandes famílias de povos indígenas: Aruak e Tukano Oriental, que influenciam, de forma bastante significativa, a cultura e a língua Dâw (AIKHENVALD 2012). Há, ainda, um grande número de indivíduos, de grupos étnicos diversos, que atualmente falam Nheengatú (ou Língua Geral Amazônica), de origem Tupi.

\footnotetext{
${ }^{1}$ Essa pesquisa teve como material de apoio os trabalhos de LIMA (2008), que aborda a estrutura argumental dos verbos na língua Juruna (Yudja); NOGUEIRA (2011), que aborda a morfossintaxe da língua Wajoro; e ROCHA (2011), que aborda a estrutura argumental dos verbos na língua Karitiana. Todas essas línguas pertencem à família Tupi.

${ }^{2}$ Informação fornecida por Martins, V. no VIII Congresso Internacional da ABRALIN, 2013.
} 


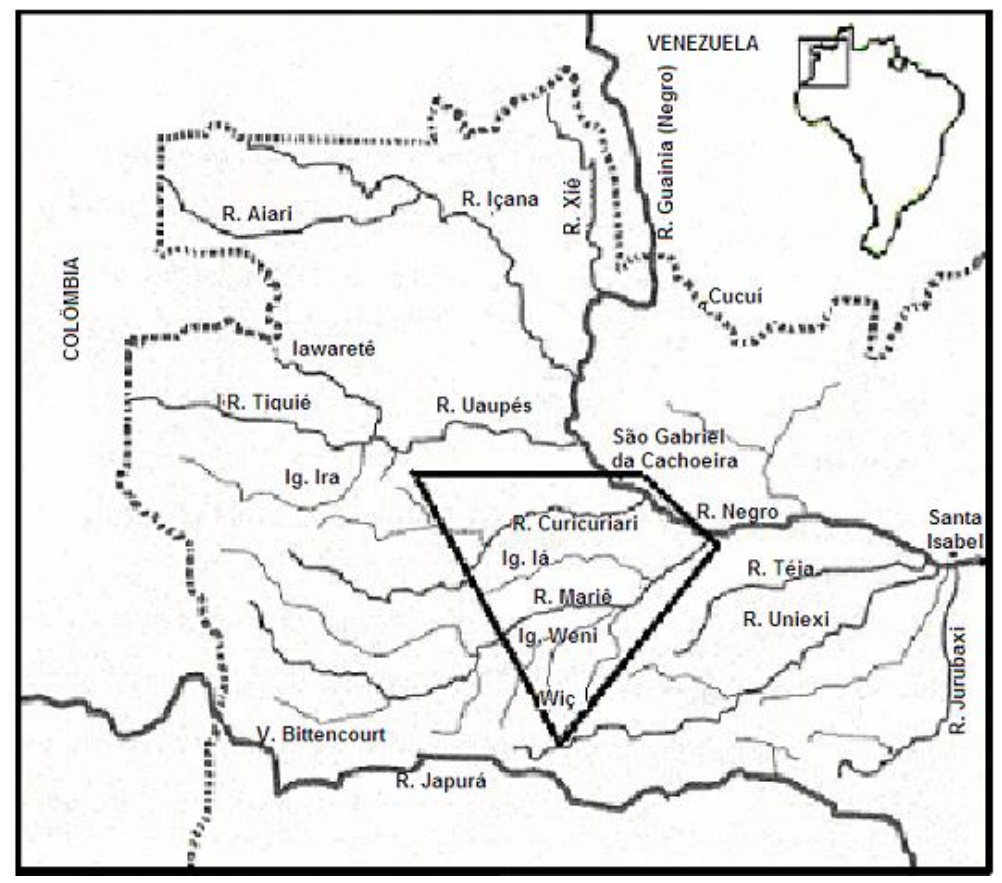

Mapa 1.0: Área tradicional do povo Dâw (MARTINS 2004:5)

Os Dâw pertencem à mesma família linguística dos povos Nädeb, Hup e Yuhup, conhecida, pela literatura, como família Maku. Este nome gera muita polêmica entre os povos indígenas e entre os pesquisadores dessas línguas, pois este termo, possivelmente de origem Aruak, possui um significado pejorativo como sem fala, selvagem, primitivo, servidor (MARTINS, 2004). Além disso, o nome Maku também é usado para denominar uma série de línguas e grupos amazônicos não relacionados com o Dâw e com suas línguas irmãs, como Máku ou Makú, falada no rio Auari, em Roraima, Brasil; Mako ou Cofán-Makú, falada na área do lago Cuyabeno, na Colômbia e no Equador; e Makú, Sáliba-Maco, ou Maco-Piaroa, um subgrupo que pertence à família SálibaPiaroa, na Venezuela (MARTINS \& MARTINS 1999). Diante desses agravantes, o uso do nome Maku está sendo evitado pelos pesquisadores da língua Dâw e de suas línguas irmãs, assim como pelas próprias comunidades indígenas.

Ainda não há um consenso entre os pesquisadores e os indígenas em relação ao melhor nome a ser adotado. Algumas propostas já foram feitas, como a de Epps (2005), que propõe o nome Nadahup - termo que combina o nome das quatro línguas da família: Nadëb, Dâw, Hup e Yuhup. Adotaremos, nessa pesquisa, o nome Nadahup para denominar a família linguística das quatro línguas supracitadas, uma vez que consideramos o nome proposto um termo neutro em relação aos já apresentados até o momento. 
A discussão em torno do nome da família linguística Nadahup revela outro problema social que envolve os povos Nadahup, em especial o povo Dâw. Segundo historiadores do Rio Negro, desde o início do povoamento dessa região, os Nadahup sempre foram considerados povos de cultura simples e inferior em relação aos outros povos. Nesse panorama social, estabeleceu-se uma relação de patrão-escravo entre os povos Aruak e Tukano (como patrões) e os Nadahup (como escravos).

Segundo Assis (2001 apud MARTINS 2004), dentre os povos da família Nadahup, os Dâw foram os mais discriminados entre eles. Na região do Alto Rio Negro, eles também eram conhecidos como Kamã, termo pejorativo que designa alguém inferior e baixo em relação aos demais. É importante salientar que este tipo de situação pode ocorrer frequentemente em qualquer lugar do mundo com povos nômades ${ }^{3}$.

Segundo Martins (2004) essa discriminação advém de uma condição social que assolou os Dâw durante alguns anos. Entre as décadas de 70 e 90, os Dâw eram vistos pelo município de São Gabriel da Cachoeira em condições precárias. Sempre estavam bêbados, mendigando, roubando, sem terra para morar. Provavelmente, esse período coincide com uma intensificação do contato entre o grupo e a vida na cidade. Atualmente, eles ocupam uma região demarcada, possuem suas próprias casas, a aldeia tem escola e gerador de energia, os idosos recebem aposentadoria rural e os membros da comunidade se identificam enquanto grupo. Já não há mais problemas sérios de vícios e vários membros da comunidade trabalham nas roças, na escola ou em algum serviço na cidade.

\subsubsection{A língua}

A língua Dâw, que leva o mesmo nome da etnia, foi estudada pelo casal de missionários Silvana e Valteir Martins, que pesquisaram a fonologia, a morfologia, a sintaxe e a semântica da língua Dâw.

Segundo Martins (2004), o inventário fonológico Dâw é composto por vinte e cinco consoantes e quinze vogais. As consoantes são divididas em sonorantes e nãosonorantes. Aquelas podem ser glotalizadas, enquanto que estas não podem. As vogais podem ser orais e nasais, sendo que vogais médio-fechadas $(/ \mathrm{o} /$, /e/ e / / /) não podem ser nasalizadas, já as outras vogais não possuem esse tipo de restrição.

\footnotetext{
${ }^{3}$ Os povos da família Nadahup sempre foram nômades.
} 
Segundo Martins (2004), a língua Dâw se apresenta, tipologicamente, como isolante-analítica com poucos processos de sufixação. Seu léxico é predominantemente monossilábico e há um baixo índice de ocorrências de afixos, sendo que, nessa língua, não há ocorrência de prefixos, apenas sufixos. Como veremos adiante, esse fator morfológico do Dâw possui um grande peso no modo como elicitamos os dados morfossintáticos da língua nesse trabalho.

Para Martins (2004), os tons possuem um papel muito importante. Segundo a autora, além da função default lexical, de diferenciação de significado em itens lexicais homófonos, os tons acumulariam funções morfológicas, atuando na nominalização de verbos e funções sintáticas, alterando valências verbais e criando nomes derivados. Nos próximos capítulos, discutiremos com mais detalhes essa questão, principalmente no que se refere à mudança de valência. De antemão, informamos o leitor que neste trabalho contrariamos a hipótese de Martins (2004) quanto ao papel do tom nos processos de mudança de valência dos verbos. Resultados de coleta de dados mostrounos que os tons não participam dos processos de mudança de valência dos verbos, mas sua ocorrência possui um padrão fonológico claro e não está condicionado a processos morfossintáticos de nenhuma natureza ${ }^{4}$.

Segundo a autora, não haveria em Dâw uma classe de adjetivos. A função de modificar nomes seria exercida por uma classe de verbos estativos que além de função predicativa, também teria função modificadora. No entanto, como o leitor irá ver adiante, contrariamos Martins (2004) ao apresentar dados de elicitação que mostram que na língua em estudo há adjetivos que modificam nomes. Esses adjetivos se verbalizam por meio de uma cópula, rãm, que toma como complemento o adjetivo. Dessa forma, a função verbal é assumida pela composição 'adjetivo + cópula'. Assim, não achamos um predicado verbal que assuma as duas funções, modificadora de NPs e predicativa, como analisado pela autora.

Os traços de plural, aspecto e tempo são indicados, preferencialmente, por morfemas livres, e não por afixos. Com relação à morfologia nominal, Martins (2004) afirma que a marcação de número nos nomes pode ser feita por meio dos conjuntivos (classe de palavras funcional) com função quantificadora, que estabelece a relação de conjunto entre entidades, por numerais e pelo morfema tonal ascendente denominado de aumentador, que aumenta o grau de nomes. Exemplo: [bok] 'panela', [bók] 'panelaço'.

\footnotetext{
${ }^{4}$ Para mais detalhes, ver capítulo 4 desta dissertação.
} 
Para a autora, essas classes gramaticais fazem referência à pluralidade de um conjunto. Todavia, não está claro ainda para nós se essa é a melhor descrição dos fatos, pois é importante identificar testes que diferenciem os vários processos que afetam os nomes para que se possa definir a estrutura do sintagma nominal nas várias construções da língua.

Segundo Martins (2004), a ordem dos constituintes marcaria duas classes de orações em Dâw: assertivas e não-assertivas. Nas orações assertivas, a ordem é SVO. Nas orações não-assertivas, a ordem pode ser de dois tipos: VOS, em sentenças interrogativas e VSO, em orações imperativas.

Com relação ao sistema de caso, a literatura analisa a língua Dâw, assim como as outras línguas Nadahup (com exceção do Nadëb), como uma língua nominativoacusativa (CAMPBELL \& GRONDONA, 2012:276; AIKHENVALD, 2012:204; MARTINS \& MARTINS, 1999:263). No entanto, Martins (2004) não apresenta em seu trabalho uma análise quanto a este aspecto especificamente. Todavia, percebemos que a língua apresenta morfologia de caso associada somente aos objetos, indiretos e diretos. Nesse trabalho, analisamos essa marcação como Marcação Diferencial de Objeto $(\mathrm{MDO})^{5}$. Sujeitos, tanto de sentenças transitivas quanto intransitivas, não apresentam morfologia de caso aparente.

\subsubsection{A ortografia}

A língua Dâw possui ortografia própria, que nos foi ensinada pelo professor Roberto da escola indígena Dâw. Segundo o professor, essa ortografia é ensinada na escola e foi desenvolvida pelos professores da comunidade em conjunto com Valteir Martins. A seguir, apresentamos as convenções ortográficas da língua, que serão usadas por nós na elicitação dos dados em toda a dissertação.

\section{(1) Sistema fonológico e ortográfico da língua Dâw}

\footnotetext{
5 Essa marca é empregada de acordo com traços semânticos do objeto marcado. Esses traços estão relacionados a distinções de referencialidade baseadas em escalas de definitude e animacidade. Para mais detalhes, ver capítulo 7 .
} 


\section{Consoantes}

\begin{tabular}{|c|c|c|c|c|c|c|c|c|c|}
\hline \multicolumn{5}{|c|}{ Fonemas (IPA) } & \multicolumn{5}{|c|}{ Ortografia } \\
\hline$p$ & $\mathrm{t}$ & c & $\mathrm{k}$ & $?$ & $\mathbf{p}$ & $t$ & ç & k & , \\
\hline \multirow[t]{2}{*}{$b$} & $\mathrm{~d}$ & $t$ & $\mathrm{~g}$ & & b & d & j & g & \\
\hline & & $\int$ & $x$ & $\mathrm{~h}$ & & & s & $\mathbf{x}$ & $\mathbf{r}$ \\
\hline $\mathrm{m}$ & $\mathrm{n}$ & $\mathrm{n}$ & $\eta$ & & m & $\mathbf{n}$ & $\mathrm{nh}$ & gn & \\
\hline $\mathrm{m}^{2}$ & $n^{2}$ & $n^{2}$ & & & $\mathbf{m}^{\prime}$ & $n^{\prime}$ & nh' & gn' & \\
\hline & I & & & & & I & & & \\
\hline & $P^{?}$ & & & & & i & & & \\
\hline w & j & & & & w & $y$ & & & \\
\hline$w^{2}$ & $j^{?}$ & & & & $w^{\prime}$ & $y^{\prime}$ & & & \\
\hline
\end{tabular}

Quadro 1.0: Fonemas consonantais e ortografia Dâw

\section{Vogais}

\begin{tabular}{|c|c|c|c|c|c|}
\hline \multicolumn{3}{|c|}{ Fonema (IPA) } & \multicolumn{3}{|c|}{ Ortografia } \\
\hline i & $m$ & $\mathrm{u}$ & $\mathbf{i}$ & H & $\mathbf{u}$ \\
\hline \multirow[t]{2}{*}{ i } & ũ & $\tilde{u}$ & $\mathbf{i}$ & $\tilde{\mathrm{u}}$ & \\
\hline & & & & & ũ \\
\hline \multirow[t]{5}{*}{ e } & $\gamma$ & o & ê & â & ô \\
\hline & $\varepsilon$ & o & & e & o \\
\hline & $\tilde{\varepsilon}$ & $\tilde{\jmath}$ & & $\tilde{\mathbf{e}}$ & õ \\
\hline & $\mathrm{a}$ & & & a & \\
\hline & ã & & & ã & \\
\hline
\end{tabular}

Quadro 1.1: Fonemas vocálicos e ortografia Dâw

Com relação às convenções ortográficas dos diacríticos, algumas considerações importantes devem ser feitas:

- As vogais nasais são marcadas com o diacrítico til ( );

- Em início de palavra, a consoante glotalizada é marcada antes do grafema. Exemplo: $w^{?}$ é grafado como 'w. Em fim de palavra, o diacrítico ocorre depois do fonema: w'. 
- O tom é marcado com a duplicação da vogal sobre a qual ele recai, pois os padrões tonais são de contorno (ascendente $(\widehat{\mathrm{LH}})$ e descendente $(\widehat{\mathrm{HL}})$ ). Os diacríticos que marcam vogais médias $\left({ }^{\wedge}\right)$ ou nasais $(\sim)$ não se duplicam nesses casos. Exemplo: /bŕd/ - bâa $\underline{a}$ 'derramar'.

\subsubsection{A família linguística}

A família linguística Nadahup está distribuída em duas regiões amazônicas brasileiras: a região média e alta do Rio Negro, entre os Rios Vaupés e Japurá, na fronteira entre Brasil e Colômbia.

A região dos Vaupés é conhecida como uma área de diversidade linguística, na qual convivem três grupos linguísticos não relacionados entre si, mas que influenciaram uns aos outros: Tukano Oriental (Tukano, Wanano, Desano, Tuyuca, Barasano, Piratapuya, entre outras), Aruak (Tariana) e Nadahup (Hup, Yuhup, Dâw e Nadëb).

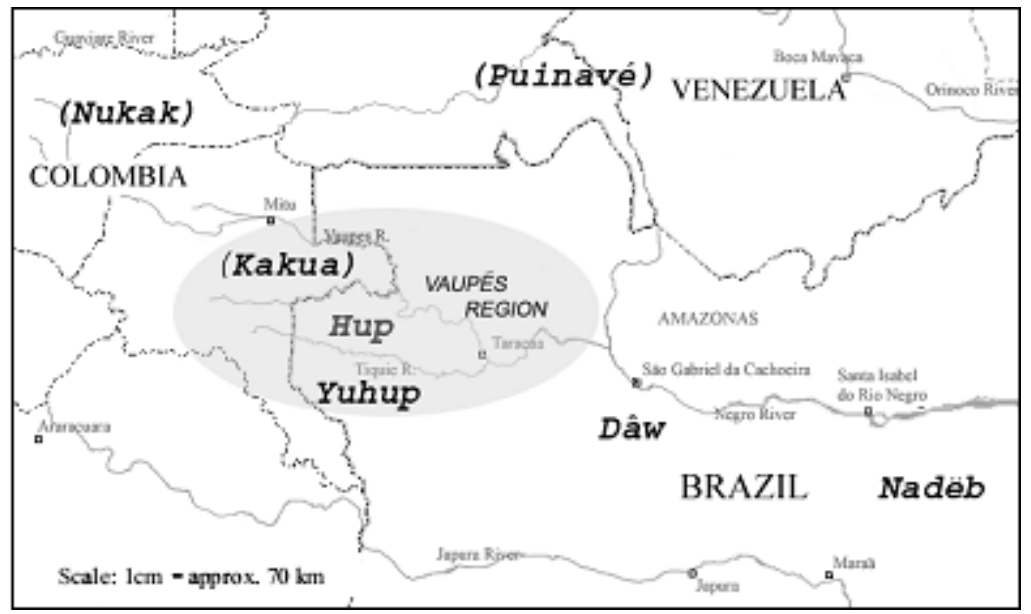

Mapa 1.1: Localização das línguas Nadahup (EPPS, 2005:6)

A família Nadahup é formada por quatro línguas: Nadëb, Dâw, Hup e Yuhup. Estas duas últimas línguas, Hup e Yuhup, são quase mutualmente inteligíveis. Dâw e Nadëb apresentam um sistema linguístico menos inteligível em relação às outras duas línguas, sendo que Dâw ${ }^{6}$ é mais próxima de Hup e Yuhup, do que a língua Nadëb ${ }^{7}$, que é significativamente a mais diferente das três línguas citadas.

\footnotetext{
${ }^{6}$ Dâw compartilha aproximadamente $75 \%$ de vocabulário cognato com Hup e Yuhup (MARTINS \& MARTINS 1999).

${ }^{7}$ Nadëb compartilha aproximadamente $50 \%$ de vocabulário cognato com Hup e Yuhup (MARTINS \& MARTINS 1999).
} 
De acordo com Martins \& Martins (1999), o vocabulário Dâw, Hup e Yuhup tende a ser monossilábico, diferentemente de Nadëb, que é uma língua polissintética com um sistema de prefixação muito rico. Dâw, Hup e Yuhup durante longos anos mantiveram contato com os falantes da língua Tukano. A difusão areal dessas tribos indígenas em direção ao Alto Rio Negro pode ser o motivo das línguas Dâw, Hup e Yuhup serem tão diferentes de Nadëb, que se isolou do resto do grupo, ocupando, atualmente, a região de Santa Isabel do Rio Negro.

Segundo Epps (2005), estudos anteriores (MARTINS \& MARTINS 1999, entre outros) incluem entre as línguas da família Nadahup outras duas línguas presentes na região dos Vaupés: Kakua e Nukak, línguas faladas na Colômbia e muito próximas entre si. Para Epps (2005), a proposta de Martins \& Martins (1999) de aproximação dessas três línguas com a família linguística Nadahup não é conclusiva, pois apresenta dados insuficientes para estabelecer uma conexão definitiva, uma vez que a taxa de aproximação entre as línguas colombianas e as línguas Nadahup não ultrapassa 35\%.

Aikhenvald (2012) também discute as controvérsias envolvendo a formação exata da família Nadahup. Segundo a autora, os membros indiscutíveis dessa família são Hup, Yuhup, Dâw e Nadëb. A inserção das línguas Kakua e Nukak ainda precisa ser adequadamente estudada, uma vez que ainda não há provas linguísticas adequadas que evidenciem a inserção dessas duas línguas colombianas dentro da família linguística Nadahup. Com relação à inteligibilidade do Nadëb e das outras três línguas Nadahup, apesar da diferença existente entre elas, é possível identificar uma origem linguística em comum entre as quatro línguas do Alto Rio Negro.

Diante desse quadro, consideramos, assim como Epps (2005) e Aikhenvald (2012), a seguinte formação da família Nadahup, em que observamos uma aproximação linguística entre Hup e Yuhup, em seguida Dâw e Nadëb.

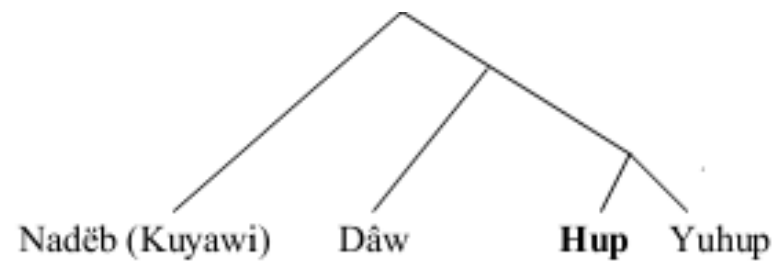

Figura 1.0: Família Nadahup: formação e correspondências (EPPS, 2005:4) 


\subsection{Trabalho de campo}

Os dados analisados neste trabalho foram coletados em três trabalhos de campo realizados em três períodos distintos. A seguir, apresentamos uma tabela na qual especificamos o período, os testes realizados e a quantidade de informantes testados em cada trabalho de campo.

\begin{tabular}{|c|c|c|c|}
\hline $\begin{array}{c}\text { Trabalho de } \\
\text { Campo } \\
\end{array}$ & Período & Testes realizados & $\begin{array}{c}\text { Informantes } \\
\text { testados }\end{array}$ \\
\hline $\begin{array}{c}\text { Trabalho de } \\
\text { campo } 1\end{array}$ & $\begin{array}{llll}22 & \text { a } & 26 & \text { de } \\
\text { fevereiro de } & 2013 \\
\text { (duração de } & 5 \text { dias) }\end{array}$ & $\begin{array}{l}\text { i. Alternância causativo- } \\
\text { incoativa com } 9 \text { verbos } \\
\text { intransitivos e } 2 \text { transitivos; } \\
\text { ii. Causativização analítica } \\
\text { com } 9 \text { verbos intransitivos } \\
\text { e } 2 \text { transitivos; } \\
\text { iii. Aplicação da morfologia } \\
\text { MDO com } 2 \text { verbos } \\
\text { transitivos e } 1 \text { bitransitivo; } \\
\text { iv. Extração de constituintes } \\
\text { com } 2 \text { verbos transitivos e } \\
1 \text { bitransitivos. }\end{array}$ & $3-\mathrm{V}, \mathrm{M}$ e $\mathrm{R}$ \\
\hline $\begin{array}{c}\text { Trabalho de } \\
\text { campo } 2\end{array}$ & $\begin{array}{l}\text { 28 de junho a } 31 \text { de } \\
\text { julho de } 2013 \\
\text { (duração de } 34 \\
\text { dias) }\end{array}$ & 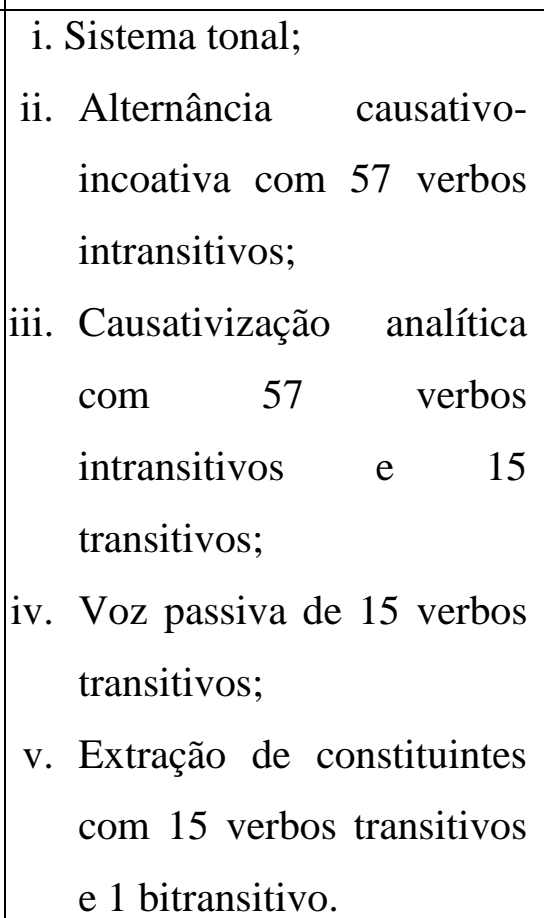 & $\begin{array}{l}4-\mathrm{V}, \mathrm{M}, \mathrm{S} \text { e } \\
\mathrm{T} .\end{array}$ \\
\hline Trabalho de & 08 de janeiro a 13 & i. Alternância & $3-V, S$ e $P$ \\
\hline
\end{tabular}




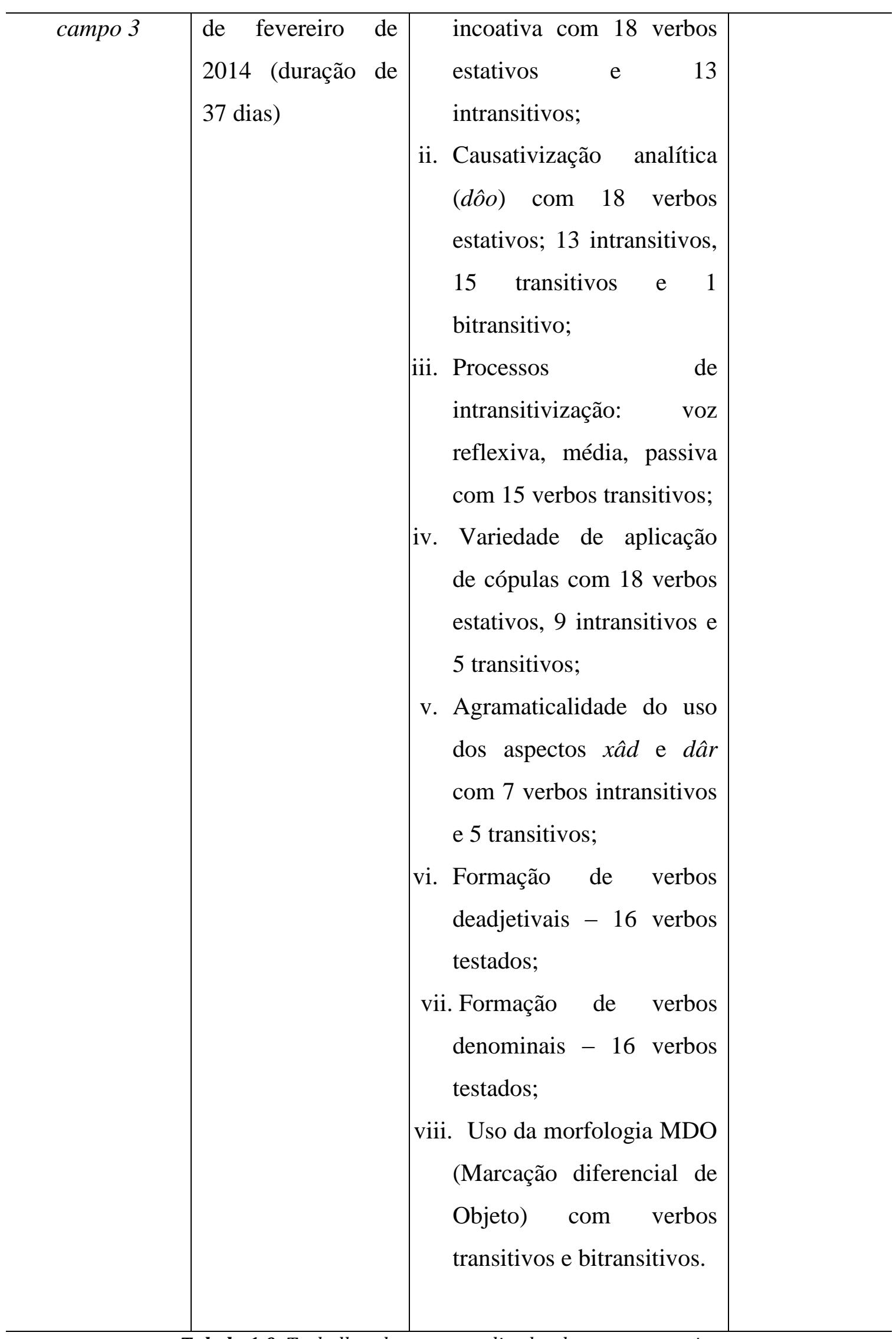


Todas as sessões de elicitação foram realizadas na comunidade Waruá, situada na cidade de São Gabriel da Cachoeira, no estado do Amazonas. Elas foram gravadas e armazenadas em dois bancos de dados: banco pessoal da pesquisadora (com backup no banco de dados pessoal da orientadora); banco de dados do projeto Documentation of Dâw, a Nadahup language of Brazil, projeto de documentação da língua e cultura Dâw coordenado pelas professoras doutoras Patience Epps, da Universidade do Texas (EUA), e Luciana R. Storto, da Universidade de São Paulo. Esta pesquisa de mestrado se coaduna com este projeto de documentação, que é financiado pelo ELDP (concessão número SG0208).

\subsection{Corpus}

Testamos 86 verbos da língua Dâw. A seguir, apresentamos uma tabela com todos os verbos elicitados e analisados nessa pesquisa. A classificação em classes verbais apresentada é uma proposta do presente trabalho.

\begin{tabular}{c|l|l|l}
\hline Número & \multicolumn{1}{|c|}{ Verbo em Dâw } & \multicolumn{1}{c}{ Tradução } & \multicolumn{1}{c}{ Classe Verbal } \\
\hline 1 & wutd & Chegar & Verbo intransitivo \\
\hline 2 & baad & Virar & Verbo intransitivo \\
\hline 3 & eed & Virar & Verbo intransitivo \\
\hline 4 & bâar & Derramar & Verbo intransitivo \\
\hline 5 & pêt & Quebrar & Verbo intransitivo \\
\hline 6 & woox & Quebrar & Verbo intransitivo \\
\hline 7 & xop & Secar & Verbo intransitivo \\
\hline 8 & pô & Abrir & Verbo intransitivo \\
\hline 9 & tobuk & Fechar & Verbo intransitivo \\
\hline 10 & yapilu & Começar & Verbo intransitivo \\
\hline 11 & çêe & Espalhar & Verbo intransitivo \\
\hline 12 & rud & Derreter & Verbo intransitivo \\
\hline 13 & rũ & Terminar & Verbo intransitivo \\
\hline 14 & wâg & Balançar & Verbo intransitivo \\
\hline 15 & pâd & Rolar & Verbo intransitivo \\
\hline 16 & rã & Parar & Verbo intransitivo \\
\hline 17 & leg & Apagar & Verbo intransitivo \\
\hline
\end{tabular}




\begin{tabular}{|c|c|c|c|}
\hline 18 & 'ox & Correr & Verbo intransitivo \\
\hline 19 & rôd & Sair & Verbo intransitivo \\
\hline 20 & 'ãa & Dormir & Verbo intransitivo \\
\hline 21 & suuk & Caçar & Verbo intransitivo \\
\hline 22 & yelêew & Transformar-se & Verbo intransitivo \\
\hline 23 & kog'õogn & Desmaiar & Verbo intransitivo \\
\hline 24 & çeeb & Mudar & Verbo intransitivo \\
\hline 25 & ' $\mathrm{tb}$ & Acordar & Verbo intransitivo \\
\hline 26 & çom & Banhar & Verbo intransitivo \\
\hline 27 & win & Trabalhar & Verbo intransitivo \\
\hline 28 & nõx & Cair & Verbo intransitivo \\
\hline 29 & kũm & Afundar & Verbo intransitivo \\
\hline 30 & pôw' & Boiar & Verbo intransitivo \\
\hline 31 & pêg-saak & Crescer & Verbo intransitivo \\
\hline 32 & stux & Esfarelar & Verbo intransitivo \\
\hline 33 & 'õot & Chorar & Verbo intransitivo \\
\hline 34 & çâk & Pular & Verbo intransitivo \\
\hline 35 & roo' & Tossir & Verbo intransitivo \\
\hline 36 & 'ô & Rir & Verbo intransitivo \\
\hline 37 & âaw & Gritar & Verbo intransitivo \\
\hline 38 & yũmrũ & Cantar & Verbo intransitivo \\
\hline 39 & yam & Dançar & Verbo intransitivo \\
\hline 40 & yok & Nadar & Verbo intransitivo \\
\hline 41 & çâ & Saltar & Verbo intransitivo \\
\hline 42 & leep & Brilhar & Verbo intransitivo \\
\hline 43 & xaam & Vomitar & Verbo intransitivo \\
\hline 44 & bax & Suar & Verbo intransitivo \\
\hline 45 & bâay & Arrotar & Verbo intransitivo \\
\hline 46 & baak & Soluçar & Verbo intransitivo \\
\hline 47 & ratĩs & Espirrar & Verbo intransitivo \\
\hline 48 & kas & Estragar & Verbo intransitivo \\
\hline 49 & yum & Melhorar & Verbo intransitivo \\
\hline
\end{tabular}




\begin{tabular}{|c|c|c|c|}
\hline 50 & rãm xo & Andar & Verbo intransitivo \\
\hline 51 & xaw & Ferver & Verbo intransitivo \\
\hline 52 & beg & Clarear & Verbo intransitivo \\
\hline 53 & rõ & Queimar & Verbo intransitivo \\
\hline 54 & baax & Aparecer & Verbo intransitivo \\
\hline 55 & xub-sõk rãm & Estar triste & Verbo intransitivo \\
\hline 56 & kub rãm & Estar escuro & Verbo intransitivo \\
\hline 57 & rân rãm & Estar velho & Verbo intransitivo \\
\hline 58 & duy rãm & Estar sujar & Verbo intransitivo \\
\hline 59 & mẽn rãm & Ser curto & Verbo intransitivo \\
\hline 60 & pêg rãm & Ser grande & Verbo intransitivo \\
\hline 61 & ça rãm & Ser preto & Verbo intransitivo \\
\hline 62 & lâk rãm & Ser magro & Verbo intransitivo \\
\hline 63 & çii rãm & Ser azedo & Verbo intransitivo \\
\hline 64 & dep rãm & Ser gordo & Verbo intransitivo \\
\hline 65 & tâaw rãm & Estar bravo & Verbo intransitivo \\
\hline 66 & kas rãm & Ser feio & Verbo intransitivo \\
\hline 67 & muj rãm & Ser úmido & Verbo intransitivo \\
\hline 68 & wê rãm & Estar molhado & Verbo intransitivo \\
\hline 69 & sêj rãm & Estar cheio & Verbo intransitivo \\
\hline 70 & 'wât rãm & Ser comprido & Verbo intransitivo \\
\hline 71 & rõk & Cortar & Verbo transitivo \\
\hline 72 & kâs & Morder & Verbo transitivo \\
\hline 73 & yũt & Matar & Verbo transitivo \\
\hline 74 & wây & Ver & Verbo transitivo \\
\hline 75 & mũm & Abraçar & Verbo transitivo \\
\hline 76 & çũnh & Beijar & Verbo transitivo \\
\hline 77 & ya’ & Assar & Verbo transitivo \\
\hline 78 & xa & Cozinhar & Verbo transitivo \\
\hline 79 & âg & Beber & Verbo transitivo \\
\hline 80 & rê' & Cavar & Verbo transitivo \\
\hline 81 & nee & Fazer & Verbo transitivo \\
\hline
\end{tabular}




\begin{tabular}{l|l|l|l}
\hline 82 & rõoy & Focar & Verbo transitivo \\
\hline 83 & 'ũum & Bater (genérico) & Verbo transitivo \\
\hline 84 & weed & Comer & Verbo transitivo \\
\hline 85 & paar & Saber & Verbo transitivo \\
\hline 86 & nõo & Dar & Verbo bitransitivo \\
\hline
\end{tabular}

Tabela 1.1: Lista com todos os verbos testados

\subsection{Documentation of Dâw, a Nadahup language of Brazil}

Este projeto de mestrado está inserido no projeto internacional coordenado pelas professoras doutoras Luciana R. Storto, da Universidade de São Paulo, e Patience Epps, da Universidade do Texas (EUA), de descrição e documentação da língua Dâw Documentation of Dâw, a Nadahup language of Brazil. A equipe de trabalho é formada pelas duas professoras supracitadas e pelos alunos de mestrado Jéssica C. Costa e Wallace Andrade, pós-graduandos do Departamento de Linguística DL-USP. Ademais, o projeto conta com a participação dos seguintes colaboradores: Didier Demolin, Danilo Paiva Ramos, Lirian Monteiro, Renato Athias e Ernesto Belo. Além da colaboração de dois alunos de Iniciação Científica, alunos graduandos do DL: Clariana Assis e Lucas Barboza.

O projeto, que se iniciou em fevereiro de 2013 e terminou em fevereiro de 2014 (duração de um ano) visou à documentação da língua e da cultura Dâw e à criação de um corpus linguístico, composto por áudio e vídeo, abrangendo uma variedade de discursos e gêneros, e um léxico.

De forma resumida, os principais objetivos desse projeto foram:

i. Treinamento dos falantes da língua Dâw nas práticas de documentação (gravação, transcrição, organização de dados);

ii. Estabelecimento das bases para um corpus de textos narrativos, músicas, rituais e de práticas manufatureiras que os integrantes da comunidade gostariam de documentar para as próximas gerações, como preparação de artesanatos, de venenos, de cestas, documentação de atividades como pescaria, caça, entre outros.

iii. Construção de um léxico da língua; 
iv. Descrição gramatical da língua Dâw de forma a complementar e aprofundar a descrição realizada por Martins (2004).

Os dados do léxico foram armazenados e transcritos na ferramenta FieldWorks Language Explorer - FLEx, um programa do SIL, que ajuda na documentação de línguas e na organização dos dados coletados em trabalho de campo. O programa prevê a construção de uma base de dados lexicais e tem a capacidade de receber textos que podem ser interlinearizados a partir da base lexical; assim, em cada frase dos textos, é possível inserir novos lexemas, sendo que o programa consegue, dentro de certo limite, dividir palavras em morfemas, colocando informações gramaticais, glosas e a tradução idiomática para cada frase.

Foi acordado com a comunidade de falantes, que a base de dados utilizaria as categorias definidas por Martins (2004) em sua lista de abreviaturas, e que qualquer diferença ou modificação seria adicionada em um campo especial de cada entrada lexical. Os dados coletados em campo pelo projeto foram identificados como tal, de maneira que é possível extrair da base de dados os itens identificados e analisados por Martins (2004) daqueles coletados pelos membros do projeto.

O trabalho de alimentação do banco de dados da língua Dâw foi realizado pelos pesquisadores Luciana Storto, Wallace Andrade, Clariana Assis, Patience Epps e alunos. Até o momento, o banco de dados possui 1655 entradas lexicais.

A seguir, apresentamos o layout do banco de dados Dâw no programa FLEx.

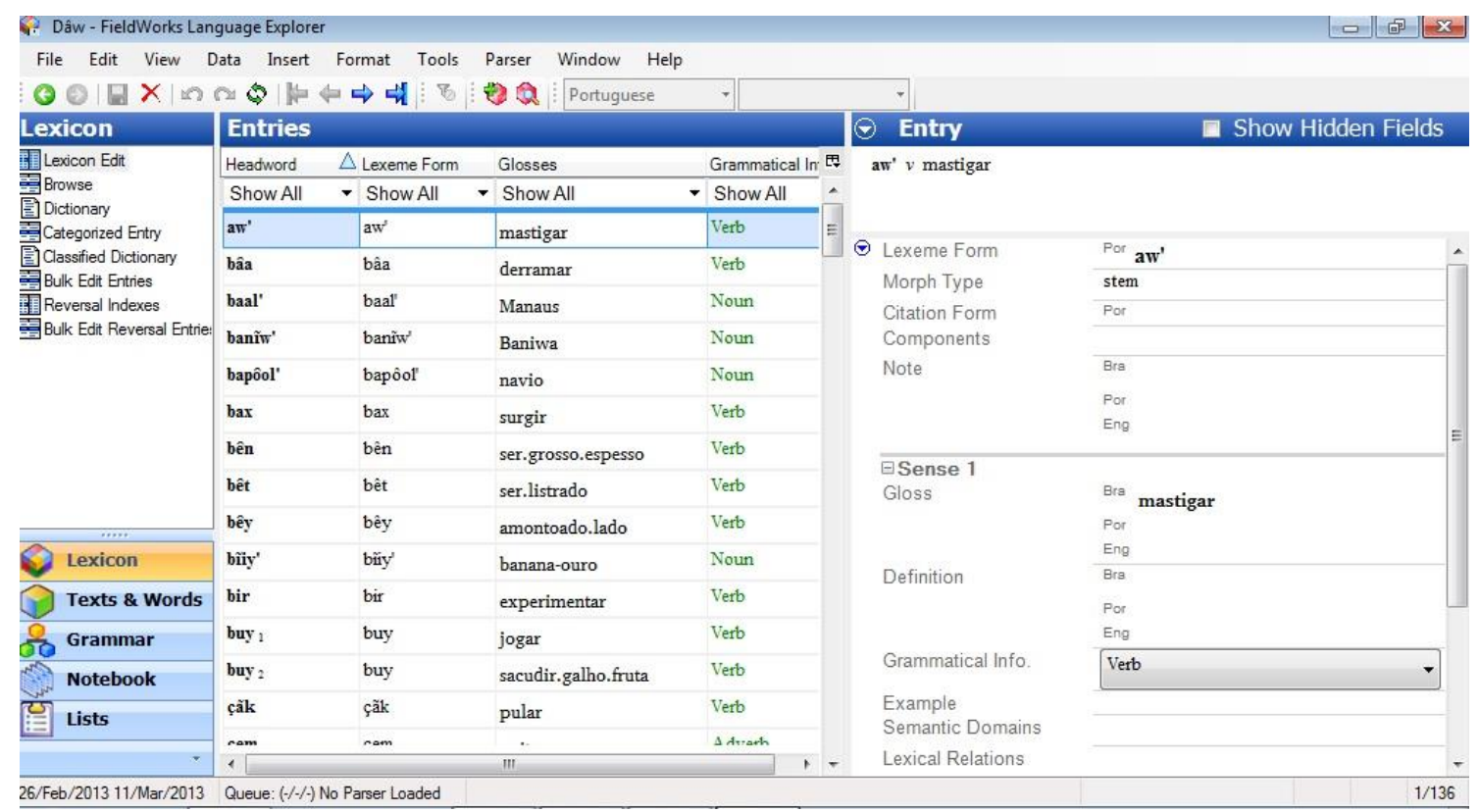

Figura 1.2: Layout do banco de dados Dâw no programa FLEx 
Outro programa que nos auxiliou na documentação de dados foi o ELAN, uma ferramenta de documentação criada pelo instituto Max Planck. Essa ferramenta permite criar, editar, visualizar e procurar anotações e banco de dados em vídeos e áudio. Com o ELAN, há a possibilidade de sincronizar áudio, vídeo e transcrição em faixas de anotações, o que, além de deixar o processo de documentação mais atraente, facilita a organização dos dados.

O trabalho com esse programa foi iniciado em julho de 2013 e finalizado em fevereiro de 2014. O trabalho de documentação conta com 70 histórias e narrativas gravadas de julho/2013 a fevereiro/2014. Há 76 textos transcritos e traduzidos, sendo 25 feitos a mão e 51 transcritos e traduzidos no ELAN.

Durante o trabalho de documentação, os alunos pós-graduandos supervisionaram os seis colaborados indígenas na tarefa de transcrição e tradução de narrativas e histórias tradicionais do povo Dâw no programa de computador ELAN. Além disso, os alunos e os colaboradores indígenas gravaram idosos que se dispuseram a contar narrativas, histórias do surgimento e do modo de vida dos antigos Dâw.

A seguir, apresentamos o layout de uma das telas do ELAN.

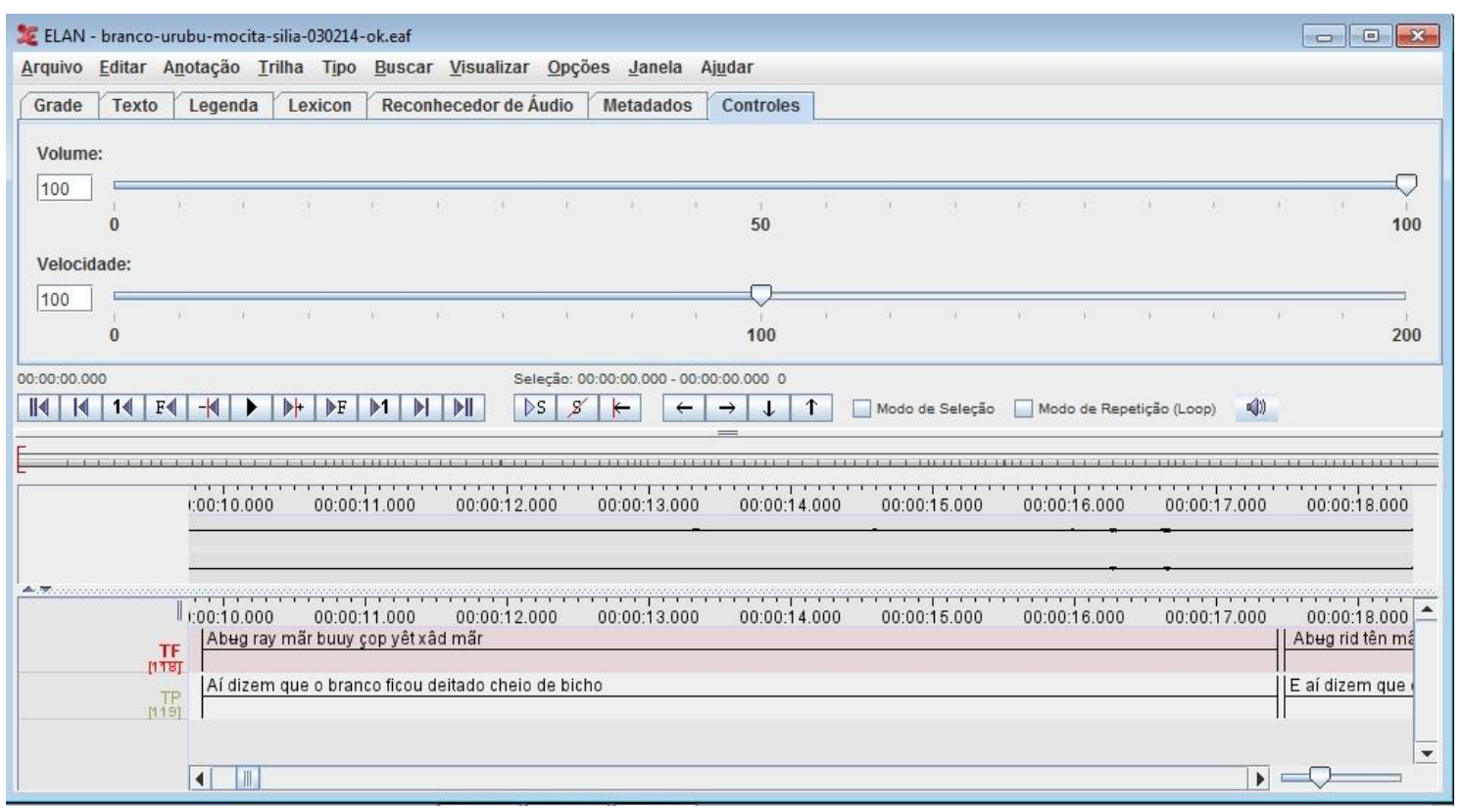

Figura 1.3: Layout do ELAN 


\subsection{Estrutura do trabalho}

Este trabalho está organizado da seguinte forma: no capítulo 2, descrevemos a metodologia adotada nesta pesquisa. No capítulo 3, analisamos e descrevemos as classes verbais da língua Dâw. No capítulo 4, analisamos e descrevemos o sistema tonal da língua em estudo e sua interface no entendimento de processos de transitivização e intransitivização. No capítulo 5, abordamos os processos de aumento de valência (transitivização e causativização analítica). No capítulo 6, apresentamos e analisamos os processos de intransitivização (construção de sentenças incoativas, reflexivas, médias e passivas). Por fim, no capítulo 7, discutimos o emprego do morfema de objeto denominado por Martins (2004) como caso afetado e analisado por nós como Marcação Diferencial de Objeto (MDO). 


\section{Capítulo 2: Metodologia do trabalho}

\subsection{Introdução}

Neste capítulo, apresentaremos a metodologia empregada nos três trabalhos de campo realizados no desenvolvimento da pesquisa de mestrado com os colaboradores indígenas Dâw na comunidade Waruá.

De modo geral, realizamos dois tipos de testes:

i. Teste de produção de sentenças em Dâw: oferecemos um contexto situacional e solicitamos aos falantes a tradução em Dâw de sentenças formuladas em português;

ii. Teste de (a)gramaticalidade: apresentamos aos informantes sentenças escritas em Dâw, língua em estudo, e pedimos para eles julgarem as sentenças como boas ou bem formadas (gramaticais) ou ruins ou mal formadas (agramaticais).

Esses testes, organizados em questionários, tiveram o objetivo de revelar mecanismos morfossintáticos da língua capazes de evidenciar o comportamento dos verbos e de suas classes. O fato de Dâw ser uma língua isolante foi um desafio na realização dos testes linguísticos. Como essa língua não apresenta muitos morfemas presos em seu sistema, não foi possível encontrar muitos núcleos funcionais afixais que revelassem comportamentos específicos de uma determinada classe verbal. No entanto, encontramos, ao longo da elicitação dos dados, morfemas livres ou lexemas que, de alguma maneira, nos auxiliaram na tarefa de estudar e analisar as classes verbais em Dâw.

Esse capítulo está dividido da seguinte forma: na seção 2.1, apresentamos uma visão geral acerca dos testes linguísticos realizados ao longo da pesquisa; na seção 2.2, apresentamos uma visão detalhada dos testes realizados, apresentando cada um deles e discutindo a sua importância para a análise e classificação dos verbos em Dâw; na seção 2.3, apresentamos uma síntese do capítulo. 


\subsection{Visão geral da metodologia empregada na pesquisa}

Esta pesquisa tem como arcabouço teórico a teoria de estrutura argumental desenvolvida por Hale \& Keyser (2002), que propõe uma análise da sintaxe e da semântica dos itens lexicais por meio da estrutura argumental - sistema de relações estruturais estabelecidas entre o núcleo e seus argumentos (especificador e complemento) dentro de estruturas sintáticas projetadas pelo próprio núcleo (predicador).

Para atingir os objetivos gerais da pesquisa - descrição e avaliação das classes verbais da língua Dâw descritas por Martins (2004) -, partimos dos seguintes objetivos específicos:

i. Testar a alternância causativo-incoativa com pelo menos nove verbos de valência intransitiva (três verbos de cada classe identificada por Martins (2004)), a fim de determinar se o processo de transitivização de verbos intransitivos gera uma sentença transitiva em que o sujeito do verbo intransitivo básico se torna o objeto do verbo transitivo (causativizado);

ii. Testar a sintaxe e a semântica da intransitivização em Dâw, procurando identificar processos como passivização, antipassivização, construção média, reflexivização, etc;

iii. Testar se os dois processos gramaticais que envolvem mudança tonal dos verbos identificados por Martins (2004) - intransitivização por apagamento tonal e transitivização pelo acréscimo de tom - são realmente distintos ou se se trata de um único processo de mudança tonal que afeta raízes de todas as valências;

iv. Identificar mecanismos morfossintáticos que diferenciem classes verbais.

Quanto aos quatro objetivos acima elencados, antecipamos o leitor que durante nossa pesquisa:

i. Conseguimos testar a alternância causativo-incoativa com 70 verbos de valência intransitiva (50 verbos intransitivos, 4 de processo e 16 estativos, na classificação de Martins, 2004). Como veremos no capítulo 5, esse teste revelou subclasses de verbos intransitivos.

ii. Testamos a sintaxe e a semântica da intransitivização em Dâw (construções incoativas, voz passiva, reflexiva e média). De modo geral, percebemos que 
não há morfologia específica para a construção de sentenças médias, incoativas ou anticausativas. Não existem passivas em Dâw; no lugar desta voz, os falantes produzem sentenças incoativas ou com o sujeito subespecificado. As sentenças reflexivas são geradas por meio de pronomes reflexivos na posição de objeto da sentença. Mais detalhes serão discutidos no capítulo 6.

iii. Quanto aos processos de mudança de valência com reflexos no sistema tonal da língua, pudemos notar, pelos dados coletados, que o padrão tonal dos verbos é previsível e não é condicionado por nenhum processo de aumento ou diminuição de valência, como analisa Martins (2004). Dessa forma, identificamos que os dois processos identificados pela autora intransitivização por apagamento tonal e transitivização pelo acréscimo de morfema tonal - não ocorrem em Dâw. Mais detalhes serão discutidos no capítulo 4.

iv. Os mecanismos morfossintáticos que diferenciaram classes verbais em Dâw foram: morfologia de voz reflexiva, utilização dos morfemas livres xâd e dâr e transitivização automática. Mais detalhes serão discutidos nos capítulos 3 e 5 , respectivamente.

O objetivo proposto em (i) foi iniciado no Trabalho de Campo 1. Os outros três objetivos, (ii), (iii) e (iv), foram realizados nos Trabalhos de Campo 2 e 3.

De modo geral, a pesquisa foi dividida em duas fases:

i. $\quad$ Fase 1: coleta dos verbos presentes na tese de Martins (2004). Os verbos foram organizados de acordo com a tipologia proposta pela autora para depois serem confrontados com outras possibilidades de análise. A lista completa desses verbos encontra-se na seção Anexo 1 do presente trabalho.

ii. Fase 2: realização de testes linguísticos: teste de produção de sentenças e teste de (a)gramaticalidade com colaboradores indígenas. 


\subsection{Visão detalhada da metodologia empregada na pesquisa}

\subsubsection{Fase 1: compilação e organização dos verbos}

Coletamos os verbos presentes em Martins (2004) e fizemos uma compilação deles (conferir tabela em Anexo 1) em um banco de dados no qual constam as seguintes informações:

i. A forma fonética do verbo (conforme consta em Martins (2004));

ii. A forma ortográfica do verbo;

iii. A tradução do verbo (conforme consta em Martins (2004));

iv. A classe do verbo (conforme consta em Martins (2004));

v. A fonte de onde retiramos a forma verbal;

vi. O padrão tonal do verbo (conforme consta em Martins (2004)).

Contabilizamos, no total, a coleta de 658 verbos. Alguns deles foram agrupados em uma única categoria verbal, tendo em vista a aproximação semântica dada pela tradução de Martins (2004) para cada predicado.

\subsubsection{Fase 2: realização de testes linguísticos}

Conforme já foi discutido, de acordo com Martins (2004), Dâw é uma língua isolante-analítica e não apresenta muitos mecanismos morfossintáticos. A maioria das informações gramaticais é codificada por formas livres.

Essa característica da língua foi avaliada durante a fase 2 de elicitação de dados. Desse modo, além de atentarmos para a regularidade de aparecimento de formas presas nos predicados verbais testados, também foi observado o uso de formas livres nas sentenças elicitadas, conforme veremos nas subseções adiante.

\subsubsection{Teste de produção de sentenças em Dâw}

As sentenças que compuseram os testes nessa fase apresentaram os verbos em construções de alternâncias estruturais variadas. Para tanto, os testes foram divididos em três conjuntos de acordo com a valência verbal: conjunto 1 - verbos monoargumentais, conjunto $\mathbf{2}$ - verbos biargumentais e conjunto $\mathbf{3}$ - verbos com mais de dois argumentos. 


\section{Conjunto 1 - verbos monoargumentais}

Os verbos monoargumentais (valência intransitiva) foram submetidos aos seguintes testes:

i. Alternância causativo-incoativa;

ii. Causativização analítica;

iii. Identificação de raiz:

a. Adjetival;

b. Nominal;

iv. Cópulas de diversos tipos;

v. Voz reflexiva.

A lista completa de verbos elicitados e os resultados dos testes (i) e (ii) encontram-se no capítulo 5 deste trabalho, já os verbos elicitados e os resultados dos testes (iii), (iv) e (v) encontram-se no capítulo 3.

\section{i. Alternância causativo-incoativa}

O teste de alternância causativo-incoativa ou transitivização automática (Hale \& Keyser, 2002) é um processo segundo o qual um verbo intransitivo passa a transitivo, sendo que o sujeito do verbo intransitivo se torna objeto do verbo transitivizado.

Exemplo:

(1) 'O dia clareou' (verbo intransitivo);

(2) 'O sol clareou o dia' (verbo transitivo).

O argumento 'dia' é sujeito na oração (1) e objeto na oração (2). A transitivização automática é uma propriedade que revela uma estrutura argumental específica sobre uma classe de verbos. Segundo Haspelmath (1993), verbos que alternam são, geralmente, verbos de mudança de estado. $\mathrm{O}$ verbo causativo possui um agente causador (quem causa o evento verbal); e o verbo incoativo não possui um agente, mas codifica o evento verbal como espontâneo. Dessa forma, esse teste de alternância estrutural é importante na classificação dos verbos, pois ele revela subclasses de verbos intransitivos. 
$\mathrm{Na}$ elicitação da alternância causativo-incoativa em Dâw, oferecemos um contexto situacional e solicitamos aos falantes a tradução de sentenças formuladas em português com a seguinte estrutura:

\section{(3) Construção incoativa (intransitiva)}

a) $\mathrm{X}$ (agente) correu, trabalhou, acordou;

b) X (paciente) secou, quebrou, abriu.

(4) Construção causativa

a) Y (agente) FEZ correr, trabalhar, acordar X (agente);

b) Y (agente) FEZ secar, quebrar, abrir X (paciente).

\section{ii. Causativização analítica}

A causativização é um processo no qual é adicionado ao predicado verbal um argumento agente ou causa, por meio da inserção de um auxiliar causativo, aumentando a valência do verbo.

Em Dâw, esse auxiliar causativo se manifesta como o verbo dôo 'fazer'. ${ }^{1}$ Esse auxiliar antecede o verbo principal da sentença. Exemplo:

\section{(5) Dâw xut dôo 'ox taax-ũuy' \\ gente macho CAUS correr anta-MDO \\ 'O homem fez a anta correr'}

A causativização forma construções nas quais um verbo causativo aparece acima de VP. Nesse quadro, o verbo lexical ocuparia a posição de núcleo do predicado verbal. A inserção do causativizador em verbos monoargumentais causativiza-os e adicionalhes um argumento agente ou causa em todos os verbos.

$\mathrm{Na}$ elicitação da causativização analítica, oferecemos um contexto situacional e solicitamos aos falantes a tradução de sentenças formuladas em português com a seguinte estrutura:

(6) Construção incoativa (intransitiva)

a) X (agente) correu, trabalhou, acordou;

b) X (paciente) secou, quebrou, abriu.

\footnotetext{
11 Além de dôo 'fazer', também identificamos outro tipo de causativizador na língua, a saber: waay 'mandar'. No entanto, não testamos a ocorrência desse causativizador com predicados verbais de várias classes. Waay 'mandar' será testado em trabalhos futuros.
} 
(7) Construção causativa analítica com $d \hat{o} o$

a) Y (agente) FEZ X (agente) correr, trabalhar, acordar;

b) Y (agente) FEZ X (paciente) secar, quebrar, abrir.

\section{iii. Da formação dos verbos: identificação da raiz}

Além de testar a alternância estrutural dos verbos monoargumentais, também testamos a sua formação. Elaboramos testes linguísticos nos quais o objetivo foi identificar a raiz do predicado verbal. Para tanto, partimos da premissa (após observação dos predicados verbais e dos textos presentes em Martins, 2004), da possibilidade de existirem duas categorias gramaticais na base dos verbos em Dâw: raízes adjetivais e nominais.

Dessa forma, a fim de observar a existência de morfologia específica na formação de verbos denominais e deadjetivais em Dâw, elaboramos três tipos de testes:

i. Construção de sintagma;

ii. Formação de sentença com o sintagma como argumento do verbo;

iii. Formação de sentença com o sintagma como predicado verbal.

\section{iv. Construção de sintagma}

Oferecemos um contexto situacional e solicitamos aos falantes a tradução de sentenças formuladas em português com a seguinte estrutura:

(8) Raiz adjetival

a) $\mathrm{O}$ (a) $\mathrm{X}$ sujo, triste, feio.

(9) Raiz nominal

a) $\mathrm{O}$ (a) grito, tosse, pulo do(a) $\mathrm{X}$.

v. Formação de sentença com o sintagma como argumento do verbo

Oferecemos um contexto situacional e solicitamos aos falantes a tradução de sentenças formuladas em português com a seguinte estrutura: 


\section{Raiz adjetival}

a) $\mathbf{O}$ (a) $\mathbf{X}$ sujo, triste, velho chegou, caiu, morreu.

\section{Raiz nominal}

a) $\mathbf{O}$ (a) tosse, canto de $X$ parou;

b) O homem viu, ouviu o(a) grito, canto, nado de $\mathbf{X}$.

\section{vi. Formação de sentença com o sintagma como predicado verbal}

Oferecemos um contexto situacional e solicitamos aos falantes a tradução de sentenças formuladas em português com a seguinte estrutura:

\section{Raiz adjetival}

a) X não sujou, não se entristeceu, não envelheceu.

\section{Raiz nominal}

a) X não gritou, não cantou, não tossiu.

Segundo Martins (2004), os sufixos que se ligam aos verbos são: i) sufixo de negação $\{-\tilde{e} r\}$; ii) sufixo de imperativo $\{-o r\}$; iii) sufixo de imperativo negativo $\{-\tilde{e} r \tilde{r}\}$. Objetivando forçar a produção de um predicado verbal, pedimos ao informante a tradução de sentenças de negação, nas quais o verbo (de raiz adjetiva e nominal) fosse sufixado por $\{-\tilde{e} r\}$. Observamos o uso desse morfema junto ao predicado verbal nas sentenças produzidas pelos informantes.

\section{vii. Cópulas de diversos tipos}

Como veremos no capítulo 3, os verbos deadjetivais são formados a partir de cópulas. Testamos o emprego das cópulas e os sentidos que elas podem ter com os adjetivos. As cópulas testadas foram:

i. $\quad$ Estar $-p u d ; r \tilde{e} d$

ii. $\quad$ Ser - rẽd

iii. Ficar-rãm; pitar

iv. Tornar-se-yelêew

v. Ficará - rãm na

vi. Ficar sempre - rãm ti; wer 
Para tanto, pedimos aos informantes a tradução em Dâw de sentenças como as apresentadas abaixo:

i. X está sujo, triste, velho;

ii. $\mathrm{X}$ é sujo, triste, velho;

iii. $\quad \mathrm{X}$ ficou sujo, triste, velho;

iv. $\mathrm{X}$ tornou(-se) sujo, triste, velho;

v. X ficará sujo, triste, velho;

vi. $\quad \mathrm{X}$ fica sempre sujo, triste, velho.

Também testamos a possibilidade dessas cópulas ocorrerem com verbos intransitivos e transitivos. Todavia, o tipo de teste utilizado com essas duas classes foi o de (a)gramaticalidade, conforme veremos nas próximas seções deste capítulo.

\section{viii. Voz reflexiva}

Segundo Martins (2004), em Dâw haveria um morfema reflexivo, a saber, xup, que indica que o objeto possui referência idêntica ao sujeito. Segundo a autora, esse morfema pode ocorrer após o sujeito:

$$
\begin{array}{llll}
\text { Ãr } & \text { xup } & \text { xop } & \text { dâr } \\
\text { 1PS } & \text { REFLX } & \text { secar } & \text { PONT }
\end{array}
$$

'Eu mesmo me sequei'

(MARTINS: 2004, 379)

Ou após o objeto, que pode vir acompanhado do pronome reflexivo (exemplo 15) ou pode aparecer na sua forma pronominal oblíqua mĩuh (exemplo 16).

$$
\begin{aligned}
& \text { Âr çom ãr xup } \\
& \text { 1PS } \text { banhar } 1 \text { 1PS }
\end{aligned}
$$

'Eu banho a mim mesmo'

(MARTINS: 2004, 379)

$$
\begin{aligned}
& \text { Âr xup ãr tees } \quad \text { mũnh } \\
& \text { 1PS REFLX } 1 \text { 1PS cortar 1PSOBL } \\
& \text { 'Eu me corto (Lit. Eu mesmo me corto)' }
\end{aligned}
$$

(MARTINS: 2004, 379)

Como percebemos, uma vez que a voz reflexiva em Dâw exige a presença de dois argumentos correferenciais, isto é, o sujeito e o objeto, acreditamos que seu uso esteja restrito a predicados transitivos que possuem ambos os argumentos. Desse modo, 
com o objetivo de identificar morfologia que diferencie classes verbais intransitivas e transitivas, testamos o uso da voz reflexiva com predicados intransitivos a fim de observar seu comportamento.

Desse modo, formulamos sentenças em português com o seguinte tipo de estrutura:

a) Eu me sequei, virei, corri, trabalhei;

b) Eu mesmo me sequei, virei, corri, trabalhei.

Em seguida, solicitamos aos falantes a tradução em Dâw dessas sentenças formuladas e procuramos identificar o emprego de morfologia específica para voz reflexiva.

\section{Conjunto 2 - verbos biargumentais}

Os verbos biargumentais (valência transitiva) foram submetidos aos seguintes testes:

i. Causativização analítica;

ii. Processos de redução de valência:

a. Passivas;

b. Reflexivas - testes 1 e 2;

c. Médias;

d. Incoativas.

iii. Uso de morfologia de objeto - MDO

\section{i. Causativização analítica}

Na elicitação da causativização analítica com verbos transitivos, oferecemos um contexto situacional e solicitamos aos falantes a tradução de sentenças formuladas em português com a seguinte estrutura:

\section{Construção transitiva}

a) X comeu, viu, beijou Y.

\section{Construção causativa analítica com $d \hat{o} o$}

a) Y (agente) FEZ X comer, ver, beijar Z . 
A lista completa de verbos elicitados e os resultados dos testes encontram-se no capítulo 5.

\section{ii. Processos de redução de valência ${ }^{2}$}

A lista completa de verbos transitivos elicitados, os resultados e as análises dos testes apresentados nessa seção encontram-se no capítulo 6.

\section{a) Voz passiva}

Oferecemos um contexto situacional e solicitamos aos falantes a tradução de sentenças formuladas em português com a seguinte estrutura:

$\mathrm{X}$ foi cortado, mordido, comido.

Exemplo de contexto situacional utilizado:

Eu e um Tukano ${ }^{3}$ fomos para a mata e matamos um porco. Deixei o porco na casa do Tukano e da esposa dele. No dia seguinte, fui à casa do Tukano e vi que o porco foi cortado. Quem será que cortou o porco, o Tukano ou a esposa dele?

O objetivo do teste foi elicitar construções passivas de verbos transitivos acompanhadas de um contexto em que há um agente ou causa, mas ele não aparece explicitamente.

\section{b) Voz reflexiva 1}

À semelhança do teste anterior, também oferecemos um contexto situacional e solicitamos aos falantes a tradução de sentenças formuladas em português com a seguinte estrutura:

(22) X se viu, se cortou, se focou.

(23) Exemplo de contexto situacional utilizado:

\footnotetext{
${ }^{2}$ Os contextos situacionais utilizados com todos os verbos transitivos testados nessa seção encontram-se no Anexo 2

${ }^{3}$ Nome de etnia indígena que vive na região.
} 
Comprei um espelho para deixar na sala da minha casa. Meu marido chegou com uma amiga em casa e me disse: 'minha amiga se viu no espelho e não gostou do que viu.

O objetivo desse teste foi produzir sentenças nas quais sujeito e objeto possuem o mesmo referente.

\section{c) Voz reflexiva 2}

À semelhança do que foi apresentado no protocolo de elicitação para voz reflexiva com predicados intransitivos, formulamos sentenças em português com o seguinte tipo de estrutura:

a) Eu me cortei, vi, ouvi;

b) Eu mesmo me cortei, vi, ouvi.

Em seguida, solicitamos aos falantes a tradução em Dâw dessas sentenças formuladas e procuramos identificar o emprego de morfologia específica para voz reflexiva nesses tipos de construções.

\section{d) Voz média}

Oferecemos um contexto situacional e solicitamos aos falantes a tradução de sentenças formuladas em português com a seguinte estrutura:

$\mathrm{X}$ assa fácil (rápido), cozinha fácil (rápido).

Exemplo de contexto situacional utilizado:

Carne de porco assa rápido, mas carne de macaco demora mais.

O objetivo desse teste foi produzir sentenças nas quais cada verbo vem acompanhado de um contexto em que o argumento interno é o único existente e a frase vem acompanhada de um advérbio (fácil, rápido) que qualifica o evento em que o argumento interno é afetado de alguma maneira. 


\section{e) Construção incoativa}

Para testar a construção incoativa, oferecemos um contexto situacional e solicitamos aos falantes a tradução de sentenças formuladas em português com a seguinte estrutura:

(27) X já assou, cozinhou, cortou.

(28) Exemplo de contexto situacional utilizado:

Eu coloquei o porco para assar e sai. Uma hora depois voltei e perguntei para meu marido: o porco já assou?

O objetivo desse teste foi elicitar sentenças nas quais só há um argumento interno que é afetado por um evento que ocorre espontaneamente. Inserimos advérbios como já, que qualifica o evento como espontâneo e sem duração.

\section{iii. Morfologia de objeto (MDO)}

Nas sentenças transitivas do Dâw, alguns objetos são marcamos por um sufixo que nesta pesquisa analisamos como Marcação Diferencial de Objeto (MDO). Essa marca é empregada de acordo com traços semânticos do objeto marcado. Esses traços estão relacionados a distinções de referencialidade baseadas em escalas de definitude e animacidade.

Apresentamos os testes de elicitação dessa marca, assim como os resultados dos testes no capítulo 7.

\section{Conjunto 3 - verbos com mais de dois argumentos}

Em relação aos testes de produção de sentenças em Dâw, os verbos bitransitivos (mais de dois argumentos) foram submetidos apenas ao teste de produção de predicados bitransitivos, como veremos com mais detalhes na próxima seção.

\section{i. Produção de predicados bitransitivos}

Martins (2004) identifica cinco verbos bitransitivos na língua Dâw. A saber: 


\begin{tabular}{c|c|c}
\hline Número & Verbos em Dâw & Tradução \\
\hline 1 & nõo & Dar \\
\hline 2 & buy & Jogar \\
\hline 3 & yõor & Passar remédio \\
\hline 4 & yug & Pazer vinho em cima \\
\hline 5 & w'oob \\
\hline \multicolumn{2}{c}{ Tabela 2.0: Verbos bitransitivos testados } \\
\hline
\end{tabular}

Elaboramos cinco sentenças em português, uma com cada verbo da tabela acima, e pedimos para os colaboradores indígenas traduzirem para o Dâw cada uma das sentenças elaboradas, que são:
a) Eu dei comida para a criança;
b) Eu passei remédio na criança;
c) Eu fiz vinho de mel para o homem;
d) Eu joguei madeira para o homem;
e) Eu pus em cima da mesa o terçado.

Após a tradução dessas sentenças para o Dâw, analisamos os predicados verbais realizados e comparamos com os verbos bitransitivos descritos por Martins (2004). Os resultados obtidos nesse teste encontram-se no capítulo 3.

\subsubsection{Teste de (a)gramaticalidade}

Os testes de (a)gramaticalidade também foram divididos em conjuntos de acordo com a valência verbal: conjunto $\mathbf{1}$ - verbos monoargumentais; conjunto $\mathbf{2}$ - verbos biargumentais; e conjunto 3 - verbos com mais de dois argumentos.

A lista completa de verbos elicitados, os resultados e análises de todos os testes apresentados nessa seção encontram-se no capítulo 3 .

\section{Conjunto 1 - verbos monoargumentais}

Os testes de (a)gramaticalidade envolvendo verbos monoargumentais são:

i. Cópulas de diversos tipos;

ii. Uso dos morfemas xâd e dâr.

iii. Voz reflexiva. 


\section{i. Cópulas de diversos tipos}

O teste apresentado acerca do uso de cópulas com verbos deadjetivais revelou a existência das seguintes cópulas em Dâw:

i. Pud; rẽd 'Estar';

ii. Rẽd 'Ser';

iii. Rãm; pitar 'Ficar';

iv. Yelêew 'Tornar-se';

v. Rãm na 'Ficará'

vi. Rãm ti; wer 'Ficar sempre'.

Testamos o uso dessas cópulas com alguns verbos intransitivos (do tipo inergativos e inacusativos). Para tanto, apresentamos aos informantes indígenas sentenças em Dâw como as que seguem:

(29) a) X wĩnh 'trabalhou', rôd 'saiu', xop 'secou', pô 'abriu' pud; rẽd

b) X wĩnh 'trabalhou', rôd 'saiu', xop 'secou', pô 'abriu' rãm; pitar

c) $\mathrm{X}$ wĩnh 'trabalhou', rôd 'saiu', xop 'secou', pô 'abriu' yelêew

d) X winh 'trabalhou', rôd 'saiu', xop 'secou', pô 'abriu' rãm na

e) X wĩnh 'trabalhou', rôd 'saiu', xop 'secou', pô 'abriu' rãm ti; wer

Em seguida, pedimos aos informantes que julgassem as sentenças como boas (gramaticais) ou ruins (agramaticais). Caso as sentenças fossem gramaticais, pedimos aos informantes uma tradução da sentença em português.

O objetivo desse teste foi o de verificar se as cópulas diferenciam classes verbais intransitivas em Dâw.

\section{ii. Uso dos morfemas xâd e dâr}

Durante a fase 1 do nosso trabalho (ver seção 2.2.1), percebemos, por meio da análise preliminar dos dados presentes em Martins (2004), que os predicados verbais transitivos são majoritariamente sucedidos por dâr, morfema de aspecto analisado por Martins (2004) como aspecto pontual (que codifica um evento sem duração). Não foram encontradas ocorrências de predicados verbais intransitivos com essa marca aspectual.

Por outro lado, observamos que os verbos intransitivos derivados do processo de redução de valência apresentados por Martins (2004) são sucedidos pelo morfema de 
aspecto $x a ̂ d$ (morfema livre que segundo Martins (2004) indicaria eventos durativos) em quase a totalidade dos dados apresentados.

Segundo a autora, xâd e dâr são empregados de acordo com a agentividade do sujeito. Desse modo, em orações intransitivas com sujeito não agente, o verbo é sucedido por $x a ̂ d$, já em orações transitivas, com sujeito agente, o verbo é sucedido por dâr.

Um levantamento do uso de xâd em Martins (2004) revelou que de fato a ocorrência dessa marca aspectual restringe-se a verbos de valência intransitiva ou transitivos que tiveram sua valência reduzida.

Tendo em vista a relação entre o emprego dos morfemas xâd e dâr e os tipos de predicados verbais associados a essas marcas, levantamos uma hipótese:

i. O uso de dâr e xâd distingue classes verbais intransitivas e transitivas.

Para testar essa hipótese de trabalho, apresentamos aos informantes indígenas sentenças intransitivas e transitivas escritas em Dâw. Em ambas as sentenças, empregamos os morfemas xâd e dâr sucedendo o verbo. Pedimos aos informantes que julgassem a (a)gramaticalidade dos quatro tipos de sentenças formuladas, isto é, sentenças intransitivas com dâr, sentenças intransitivas com xâd, sentenças transitivas com dâr e sentenças intransitivas com xâd. Abaixo, apresentamos exemplos para ilustrar os tipos de sentenças formuladas:

\section{Sentença intransitiva com $x a ̂ d$}

a) X wĩnh 'trabalhou', rôd 'saiu', xop 'secou', pô 'abriu' xâd;

\section{Sentença intransitiva com $d \hat{a} r$}

a) X wĩnh 'trabalhou', rôd 'saiu', xop 'secou', $p \hat{o}$ 'abriu' dâr;

\section{Sentença transitiva com $x \hat{a} d$}

$\mathrm{X} k \hat{a ̂ s}$ 'mordeu', yũt 'matou' xâd Y;

\section{Sentença transitiva com dâr}

a) X kâs 'mordeu', yũt 'matou' dâr Y.

Quando as sentenças eram gramaticais, pedíamos aos informantes uma tradução da sentença em português. 


\section{iii. Voz reflexiva}

Como vimos nas seções anteriores, testamos a produção de construções reflexivas com verbos intransitivos e transitivos. Para tanto, pedimos a tradução em Dâw de sentenças em português como as que seguem abaixo:

(34) Com verbos intransitivos

a) Eu me sequei, virei, corri, trabalhei;

b) Eu mesmo me sequei, virei, corri, trabalhei.

(35) Com verbos transitivos

a) Eu me cortei, vi, ouvi;

b) Eu mesmo me cortei, vi, ouvi.

A tradução dessas sentenças em Dâw revelou algumas evidências morfológicas como as que seguem abaixo:
a) S V münh;
b) S xup V;
c) S хир V mĩnh;
d) S xup dôo V mũnh.

De posse desses padrões morfológicos, formulamos sentenças em Dâw com verbos intransitivos com estruturas semelhantes às apresentadas em (36) e pedimos aos informantes que julgassem essas sentenças como boas (gramaticais) e ruins (agramaticais). Apresentamos exemplos com esses tipos de estruturas:

(37) a) S xop 'secar', bâad 'virar', wĩnh 'trabalhar', 'ox 'correr' mũnh;

b) S xup xop 'secar', bâad 'virar', wĩnh 'trabalhar', 'ox 'correr';

c) S xup xop 'secar', bâad 'virar', wĩnh 'trabalhar', 'ox 'correr' mũnh;

d) S xup dôo xop 'secar', bâad 'virar', wĩnh 'trabalhar', 'ox 'correr' mũnh;

Quando as sentenças eram gramaticais, pedíamos aos informantes uma tradução da sentença em português.

\section{Conjunto 2 - verbos biargumentais}

Os testes de (a)gramaticalidade envolvendo verbos biargumentais são: 
i. Apagamento de constituintes;

ii. Cópulas de diversos tipos;

iii. Uso dos morfemas $x a ̂ d$ e dâr;

\section{i. Apagamento de constituintes}

Testamos a possibilidade de haver o apagamento de um dos dois argumentos obrigatórios dos verbos transitivos (sujeito ou objeto direto), como podemos ver abaixo:

\begin{tabular}{l|l|l}
\hline No & Estrutura da sentença testada & Descrição \\
\hline 1 & S V OD & Sentença declarativa defaut \\
\hline 2 & V OD & Sentença transitiva sem o sujeito \\
\hline 3 & S V & Sentença transitiva sem o objeto direto \\
\hline
\end{tabular}

Tabela 2.1: Protocolo de elicitação de construções transitivas

Em (1), testamos a sentença defaut para verbos bitransitivos; testamos também a possibilidade de haver o apagamento do sujeito, teste (2) e do objeto direto, teste (3).

Após a extração dos constituintes das sentenças, pedimos aos informantes que julgassem as sentenças como boas (gramaticais) ou ruins (agramaticais). Quando as sentenças eram gramaticais, pedíamos aos informantes uma tradução da sentença em português.

\section{ii. Cópulas de diversos tipos}

Também testamos o uso de diversas cópulas com alguns verbos transitivos. Para tanto, apresentamos aos informantes indígenas sentenças em Dâw como as que seguem:
a) X rõk 'cortou', yũt 'matou' pud; rẽd Y;
b) X rõk 'cortou', yũt 'matou' rãm; pitar Y;
c) X rõk 'cortou', yũt 'matou' yelêew Y;
d) X rõk 'cortou', yũt 'matou' rãm na Y;
e) $\mathrm{X} r o \tilde{k}$ 'cortou', yũt 'matou' rãm ti; wer Y. 
Em seguida, pedimos aos informantes que julgassem as sentenças como boas (gramaticais) ou ruins (agramaticais). Quando as sentenças eram gramaticais, pedíamos aos informantes uma tradução da sentença em português.

O objetivo desse teste foi o de verificar se as cópulas diferenciam classes verbais como intransitivas e transitivas em Dâw.

\section{iii. Uso dos morfemas xâd e dâr}

A metodologia empregada para esse teste com os verbos transitivos está descrita na seção 'Conjunto 1 - verbos monoargumentais' deste capítulo.

\section{Conjunto 3 - verbos com mais de dois argumentos}

Os testes de (a)gramaticalidade envolvendo verbos bitransitivos foram os seguintes:

i) Reconhecimento de predicados bitransitivos;

ii) Apagamento de constituintes.

\section{i. Reconhecimento de predicados bitransitivos}

A fim de verificar se os falantes da língua reconhecem os predicados bitransitivos conforme apresentado na tabela 2.0 acima, apresentamos aos colaboradores indígenas sentenças (retiradas de Martins, 2004), compostas com os cinco verbos bitransitivos analisados pela autora, como podemos ver abaixo:
a) Woor nõo tirũuy' yun kas 'O Tukano deu roupa velha para ele'
b) Kôog yõor dak tirũuy'4 'Auxiliadora passou remédio nele'
c) Dâw yug nẽeg tirũuy' 'O Dâw fez vinho de mel para ele'
d) Mũnh buy dâr rãy nô 'Derrube para mim sorva madura'
e) Tir rõk wôob dâr mân baak mũux wâ' 'Ele cortou o cacho de inajá para cair em cima do curupira'

\footnotetext{
${ }^{4}$ A sentença original'é: Sug yõor dak tirũuy', com outro nome próprio iniciando a sentença. Trocamos o nome próprio para que o desconhecimento do nome apresentado por Martins (2004) não fosse um distrator no teste realizado.
} 
Pedimos aos informantes a tradução dessas sentenças. A tradução dada pelos informantes foi contrastada com a tradução dada por Martins (2004). O objetivo desse teste foi o de verificar se o uso dos predicados presentes na obra da autora se mantém pelos falantes atuais da língua.

\section{ii. Apagamento de constituintes}

Testamos a possibilidade de haver o apagamento de um dos três argumentos obrigatórios dos verbos bitransitivos (sujeito, objeto direto, objeto indireto), como podemos ver abaixo:

\begin{tabular}{l|l|l}
\hline No & Estrutura da sentença testada & Descrição \\
\hline 1 & SV OD OI & Sentença declarativa defaut \\
\hline 2 & V OD OI & Sentença bitransitiva sem o sujeito \\
\hline 3 & S V OI & Sentença bitransitiva sem o objeto direto \\
\hline 4 & S V OD & Sentença bitransitiva sem o objeto indireto \\
\hline
\end{tabular}

Tabela 2.2: Protocolo de elicitação de construções bitransitivas

Em (1), testamos a sentença defaut para verbos bitransitivos; testamos também a possibilidade de haver o apagamento do sujeito, teste (2), do objeto direto, teste (3), e do objeto indireto, teste (4).

Após a extração dos constituintes das sentenças, pedimos aos informantes que julgassem as sentenças como boas (gramaticais) ou ruins (agramaticais). Quando as sentenças eram gramaticais, pedíamos aos informantes uma tradução da sentença em português.

\subsection{Síntese do capítulo}

Nesse capítulo, apresentamos a metodologia de pesquisa utilizada nesse trabalho. Discutimos cada um dos testes realizados, assim como o seu objetivo e sua importância para a classificação dos verbos em Dâw. Nos próximos capítulos, vamos discutir os resultados desses testes e o que eles revelam acerca dos predicados verbais em Dâw. 


\section{Capítulo 3: As classes verbais da língua Dâw}

\subsection{Introdução}

Neste capítulo, apresentamos e discutimos as classes verbais da língua Dâw.

As hipóteses sintático-semânticas de Martins (2004), quanto às classes verbais da língua Dâw, apontam para três tipos de verbos: os verbos ativos, divididos em três categorias: verbos transitivos, intransitivos e bitransitivos; os verbos de processo (de valência intransitiva); e, por fim, os verbos estativos (também de valência intransitiva), divididos em duas categorias: verbos equativos e verbos descritivos.

Como já foi discutido anteriormente, nesse trabalho, partimos de dois objetivos gerais: i) estudar as classes verbais do ponto de vista semântico e sintático, identificando classes e subclasses de acordo com o comportamento morfossintático das raízes verbais; ii) avaliar as hipóteses descritivas e explicativas das classes verbais identificadas por Martins (2004).

As alternâncias de valência foram usadas para identificar subclasses dentro de cada classe de verbos. Esse tipo de critério nos parece mais objetivo, como classificação dos verbos da língua Dâw, do que os critérios semânticos utilizados por Martins (2004), que apresenta uma análise baseada unicamente na semântica do verbo e dos seus argumentos.

Na nossa concepção, e de acordo com o nosso paradigma teórico (Hale \& Keyser, 2002), o papel temático do argumento está estritamente ligado à estrutura sintática do verbo. Dessa forma, entendemos que sujeitos agentes são argumentos externos, ou seja, são projetados na sintaxe sentencial, e não na estrutura argumental. Sujeitos pacientes são projetados internamente, e por isso, eles são argumentos internos.

Desse modo, reavaliamos as classes verbais propostas por Martins (2004) a partir da elicitação de paradigmas verbais cujos resultados são apresentados nas próximas seções.

Na seção 3.1, apresentamos, resumidamente, a proposta semântico-descritiva de classificação dos verbos realizada por Martins (2004) e as classes verbais propostas por ela. Na seção 3.2, apresentamos nossa contribuição para o entendimento das classes verbais na língua em estudo. Na seção 3.3, fazemos uma síntese do que foi discutido no capítulo. 


\subsection{As classes verbais da língua Dâw segundo Martins (2004)}

Martins (2004) classifica os verbos em Dâw de acordo com dois parâmetros semânticos:

i) A semântica do verbo: que pode ser de ação, processo (mudança de estado) ou estado;

ii) $\quad$ papel semântico do sujeito: agente ou causa, autor-paciente ${ }^{1}$, ou paciente.

Segundo a autora, esses parâmetros dividem os predicados verbais em três grandes classes:

i) Verbos ativos são verbos de ação e o sujeito é agente (ou causa). Essa classe é dividida em três categorias de acordo com o número de argumentos que o predicado verbal projeta (MARTINS, 2004:196):

a. Verbos Intransitivos (projetam um argumento). Para a autora, verbos intransitivos possuem apenas um argumento sujeito, cujo papel temático é agente. (MARTINS, 2004:198)

Exemplo:

$$
\begin{array}{llll}
\text { (1) mĩis 'ox } \quad \text { rãm } & \text { yoow } \\
\text { jabuti } & \text { correr ir } & \text { PROGI } \\
\text { 'O jabuti correu direto' ('O jabuti fugiu direto') }
\end{array}
$$

(MARTINS, 2004:199)

\begin{tabular}{c|c|c}
\hline Forma Fonética & Forma Ortográfica & Tradução \\
\hline$[\mathrm{pub}]$ & ' $\mathrm{b}$ & Acordar \\
\hline$[\mathrm{pox}]$ & 'ox & Correr \\
\hline$[\mathrm{jam}]$ & yam & Dançar \\
\hline$[\mathrm{l} \mathrm{b} b]$ & lâb & Girar \\
\hline \multicolumn{2}{r}{} \\
\hline \multicolumn{2}{c}{ Tabela 3.0: Verbos ativos intransitivos }
\end{tabular}

b. Verbos Transitivos: possuem dois argumentos: sujeito, cujo papel temático é agente; e objeto, cujo papel temático é paciente/tema. (MARTINS, 2004:199)

\footnotetext{
${ }^{1}$ Para Martins (2004), sujeito autor-paciente apresenta características tanto de agente quanto de paciente. No entanto, como agente, ele não é analisado como causador primário de uma ação, pois também é afetado pela ação verbal.
} 
Exemplo:

(2) waam weed mân -ũuy'

cutiporó $^{2}$ comer inajá ${ }^{3}$-AFET

'O cutiporó come inajá'

(MARTINS, 2004:532)

Segundo Martins (2004), os objetos podem ser marcados, opcionalmente, pelo morfema $\{-\tilde{u} z y$ '\}, que expressa caso afetado, que, para a autora, marca o constituinte afetado pela ação do verbo ${ }^{4}$. Na tabela abaixo, apresentamos alguns exemplos de verbos transitivos.

\begin{tabular}{c|c|c}
\hline Forma Fonética & Forma Ortográfica & Tradução \\
\hline$[\mathrm{w} \grave{\mathrm{d}}]$ & weed & Comer \\
\hline$[\mathrm{ju} t]$ & yũt & Matar \\
\hline$[\mathrm{tek}]$ & têk & Bater \\
\hline$\left[\int \mathrm{ip}\right]$ & sip & Querer \\
\hline \multicolumn{2}{c}{} \\
\hline \multicolumn{2}{c}{ Tabela 3.1: Verbos ativos transitivos }
\end{tabular}

c. Verbos Bitransitivos (ou ditransitivos): segundo Martins (2004), esses verbos possuem três argumentos: sujeito, objeto direto e indireto, cujos papéis temáticos são, respectivamente, agente, paciente/tema e alvo. (MARTINS, 2004:201)

Exemplo:

(3) woor nõo tir - ũuy' weed

NP dar 3SG -AFET comida

'O Tukano dá comida para ele'

(MARTINS, 2004:245)

Para Martins (2004), os objetos indiretos de verbos bitranstivivos também são marcados pelo morfema de caso afetado $\{-\tilde{u} u y '\}$. Todavia, acreditamos que, nesses contextos, o morfema de objeto não é caso afetado, mas um morfema oblíquo de forma homófona à marca que ocorre com objetos diretos de sentenças transitivas.

A seguir, apresentamos alguns exemplos de verbos ativos bitransitivos:

\footnotetext{
${ }^{2}$ Espécie de macaco (Dicionário Houaiss)

${ }^{3}$ Planta palmácea. Coco-da-baía. (Dicionário Houaiss)

${ }^{4}$ Após análise das ocorrências desse morfema nas sentenças apresentadas em Martins (2004), pudemos observar que a marca supracitada, com o objeto direto de sentenças transitivas, não é usada indistintamente, mas majoritariamente em contextos semânticos de definitude. Conforme veremos adiante, a marca de objeto que ocorre com objetos diretos pode ser analisada como um morfema de Marcação Diferencial do Objeto (MDO). Para mais detalhes, confira capítulo 7.
} 


\begin{tabular}{c|c|c}
\hline Forma Fonética & Forma Ortográfica & Tradução \\
\hline$[\mathrm{n} \tilde{?} ?]$ & nõo & Dar \\
\hline$[\mathrm{buj}]$ & buy & Jogar \\
\hline$[$ jớh $]$ & yõor & Passar remédio \\
\hline$[\mathrm{jug}]$ & yug & Fazer vinho \\
\hline$\left[\mathrm{w}^{2}\right.$ òb $]$ & w'oob & Pôr em cima \\
\hline \multicolumn{3}{c}{ Tabela 3.2: Verbos bitransitivos }
\end{tabular}

ii) Verbos de processo: são verbos de mudança de estado e de eventos espontâneos, que não necessitam de uma causa externa para ocorrer. Para a autora, esses verbos possuem valência intransitiva e projetam um único argumento sujeito, cujo papel temático é de autor-paciente, que apresenta características tanto de agente quanto de paciente (MARTINS, 2004:201).

Exemplo:

\begin{tabular}{|c|c|c|}
\hline borõ & dok rãm & m'ẽ-pêeg \\
\hline fogo & apagar ir & um-grande \\
\hline
\end{tabular}

(MARTINS, 2004: 202)

\begin{tabular}{c|c|c}
\hline Forma Fonética & Forma Ortográfica & Tradução \\
\hline$[\mathrm{h} \tilde{0}]$ & rõ & Queimar \\
\hline$[\mathrm{bax}]$ & bax & Aparecer \\
\hline$[\mathrm{d} \jmath \mathrm{k}]$ & $\mathrm{dok}$ & Apagar \\
\hline$[\mathrm{beg}]$ & bêg & Clarear \\
\hline \multicolumn{3}{c}{ Tabela 3.3: Verbos de processo } \\
\hline
\end{tabular}

De acordo com Martins (2004), verbos que designam fenômenos da natureza, como 'chover', 'anoitecer' e 'amanhecer' também são classificados como verbos de processo. Esses verbos são formas verbais compostas por um nome (por exemplo, wât 'dia') e um núcleo verbal (exemplo, ' $t b$ 'acordar'), formando construções como wât- ' $t b$ 'cair dia - amanhecer'.

$\begin{array}{lllll}\text { kub-wu } & \text { yêd } & \text { 'uyãm } & \text { tir } & \text { yâ } \\ \text { Ser escuro-cair } & \text { INTSI quando } & \text { 3SG } & \text { voltar } \\ \text { 'Quando escureceu, ele chegou' } & & \end{array}$

(MARTINS, 2004: 205) 
Exemplos:

\begin{tabular}{c|c|c}
\hline Forma Fonética & Forma Ortográfica & Tradução \\
\hline$[$ nrx-dof] & nâx-doj & Chover \\
\hline$[$ wrt-úb] & wât-utb & Amanhecer \\
\hline$[$ cem- xu] $]$ & çêm-xu & Anoitecer \\
\hline$[$ wŕt-wa $]$ & wâat-wa & Entardecer \\
\hline \multicolumn{2}{c}{ Tabela 3.4: Verbos de processo que expressam fenômenos da natureza }
\end{tabular}

iii) Verbos estativos: segundo Martins (2004), esses verbos possuem valência intransitiva e projetam um único argumento sujeito cujo papel temático é paciente/tema. Eles podem se subdividir em duas subclasses: verbos estativos equativos e verbos estativos descritivos (MARTINS, 2004: 208).

a. Verbos equativos: possuem a função de uma cópula. Eles são divididos em duas subclasses: equativos existenciais e identificacionais (MARTINS, 2004: 208).

i. Equativo Existencial: são verbos empregados para apresentar a existência de um ser (ou coisa). Exemplos:

\begin{tabular}{|c|c|c|}
\hline Forma Fonética & Forma Ortográfica & Tradução \\
\hline [nĩ] & nĩ & Estar, existir, haver \\
\hline 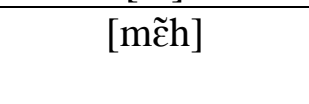 & mẽr & $\begin{array}{l}\text { Não estar, não existir, não } \\
\text { haver }\end{array}$ \\
\hline [hew] & rew & Ter ou haver muitos \\
\hline
\end{tabular}

ii. Equativo Identificacional: são verbos empregados para designar o estado de um ser (ou coisa). Exemplos:

\begin{tabular}{c|c|c}
\hline Forma Fonética & Forma Ortográfica & Tradução \\
\hline$[$ wùd] & wutd & $\begin{array}{c}\text { Ser (passado) ou } \\
\text { possibilidade de ser }\end{array}$ \\
\hline$[$ mãj] & mãy & Não ser \\
\hline$[$ mãj] & mãay & $\begin{array}{c}\text { Ser intensificado (referente } \\
\text { à quantidade e qualidade) }\end{array}$ \\
\hline [pùd] & putd & Ser mais \\
\hline [Pamãj] & 'amãy & Ser pouco \\
\hline \multicolumn{2}{c}{ Tabela 3.6: Verbos equativos identificacionais } \\
\hline
\end{tabular}

b. Verbos descritivos: Martins (2004) afirma que os verbos estativos descritivos indicam conceitos que em outras línguas são 
expressos pela classe de adjetivos, classe nominal que, segundo a autora, não existiria em Dâw. Para Martins (2004), esses verbos podem também modificar nomes, exprimindo o estado, o atributo e a posição de um nome. Nessa função, eles estariam sendo empregados como adjetivos, não como verbos. Ou seja, a função verbal é a básica e a adjetival é a derivada (MARTINS, 2004:

217). Esses verbos são divididos em:

i. Verbos Atributivos: descrevem características inerentes de um ser ou objeto, como mẽn 'ser curto', ou bêt 'ser listrado'. Exemplos:

\begin{tabular}{c|c|c}
\hline Forma Fonética & Forma Ortográfica & Tradução \\
\hline$[\mathrm{bet}]$ & bêt & Ser listrado \\
\hline$\left[\mathrm{m}^{2} \tilde{\varepsilon} \mathrm{n}\right]$ & mẽn & Ser curto \\
\hline$[\mathrm{peg}]$ & peg & Ser grande (genérico) \\
\hline$[\mathrm{x \jmath ̀d}]$ & xood & $\begin{array}{c}\text { Ser pintado, malhado (ex. } \\
\text { cachorro) }\end{array}$ \\
\hline \multicolumn{2}{c}{ Tabela 3.7: Verbos estativos atributivos } \\
\hline
\end{tabular}

ii. Verbos Qualificativos: descrevem características transitórias ou comportamentais como lê' 'ser magro', 'enh 'ser feio', dâw tâaw 'estar bravo (para gente)'. Exemplos:

\begin{tabular}{|c|c|c|}
\hline Forma Fonética & Forma Ortográfica & Tradução \\
\hline [lrk] & lâk & $\begin{array}{l}\text { Ser magro por natureza } \\
\text { (torna o osso visível) }\end{array}$ \\
\hline [nćt] & neet & Ser raso (ex. igarapé) \\
\hline [dup] & dup & $\begin{array}{l}\text { Ser azedo (ex. banana- } \\
\text { maçã; limão) }\end{array}$ \\
\hline [?हn] & 'eng & Ser feio \\
\hline
\end{tabular}

iii. Verbos Posicionais: indicam a posição e o estado de um ser ou objeto em um determinado espaço. Exemplos:

\begin{tabular}{c|c|c}
\hline Forma Fonética & Forma Ortográfica & Tradução \\
\hline$[\mathrm{p} \dot{m}]$ & peem & Estar sentado \\
\hline$[\mathrm{jet}]$ & yêt & Estar no chão \\
\hline$\left[\int \mathrm{oj}\right]$ & sôy & $\begin{array}{c}\text { Estar amontoado um em } \\
\text { cima do outro }\end{array}$ \\
\hline
\end{tabular}




\begin{tabular}{c|c|c}
\hline [prt] & pât & Estar caído na rede \\
\hline \multicolumn{3}{c|}{ Tabela 3.9: Verbos estativos posicionais } \\
\hline
\end{tabular}

Abaixo, apresentamos um quadro-síntese das classes verbais em Dâw e dos parâmetros de classificação propostos por Martins (2004).

\begin{tabular}{|c|c|c|}
\hline & \multicolumn{2}{|c|}{ Parâmetros } \\
\hline Classes verbais & Semântica do verbo & $\begin{array}{c}\text { Papel semântico do } \\
\text { sujeito }\end{array}$ \\
\hline $\begin{array}{l}\text { Verbos ativos } \\
\text { a. Verbos Intransitivos } \\
\text { b. Verbos Transitivos } \\
\text { c. Verbos Bitransitivos }\end{array}$ & Ação & Agente, causa \\
\hline Verbos de processo & $\begin{array}{c}\text { Processo (mudança de } \\
\text { estado) }\end{array}$ & $\begin{array}{l}\text { Autor-paciente (agente- } \\
\text { paciente) }\end{array}$ \\
\hline $\begin{array}{l}\text { Verbos estativos } \\
\text { a. Verbos equativos: } \\
\text { i. Verbos Identificacionais; } \\
\text { ii. Verbos Existenciais. } \\
\text { b. Verbos descritivos: } \\
\text { i. Verbos Atributivos; } \\
\text { ii. Verbos Qualificativos; } \\
\text { iii. Verbos Posicionais. }\end{array}$ & Estado & Tema \\
\hline
\end{tabular}

Tabela 3.10: Síntese dos parâmetros que classificam as classes verbais em Dâw

Para Martins (2004), as classes verbais (classe dos verbos ativos, de processo e estativos) ocupam uma posição básica em uma escala de dinamicidade de dois polos: um polo dinâmico (que abriga os verbos ativos); e um polo menos dinâmico (que abriga os verbos estativos). Os verbos de processo estariam no meio dessa escala.

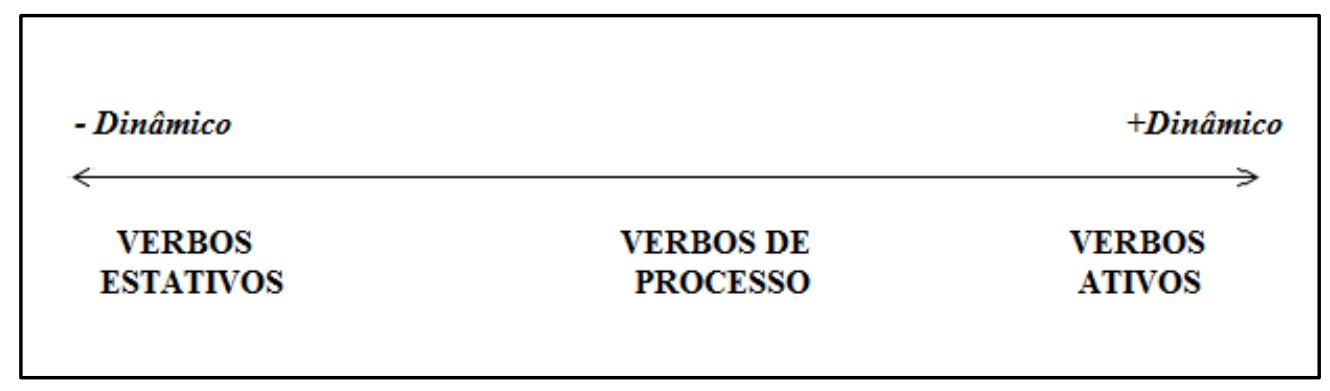

Figura 3.0: Escala de dinamicidade e classes verbais segundo Martins (2004) 
Nas próximas seções, apresentaremos nossa proposta de reanálise das classes verbais em Dâw de acordo com o comportamento sintático dos verbos em estudo.

\subsection{Reanalisando as classes verbais em Dâw}

Durante a primeira fase do nosso trabalho, na qual compilamos e organizamos os verbos descritos por Martins (2004), analisamos os contextos sentenciais e o comportamento de cada predicado verbal dentro da sentença, isto é, a relação fundamental da estrutura argumental entre verbo-objeto e verbo-sujeito (Cf. HALE \& KEYSER, 2002:2) a fim de identificar comportamentos morfossintáticos que nos auxiliassem na reclassificação dos verbos em Dâw.

Ainda nessa fase de trabalho, pudemos identificar que os verbos classificados por Martins (2004), no que se refere à relação entre o verbo e seus argumentos, possuem três padrões sintáticos de valência (número de argumentos que cada verbo possui), a saber: padrão intransitivo (um argumento), transitivo (dois argumentos) e bitransitivo (mais de dois argumentos).

Desse modo, reduzimos as nove classes verbais propostas por Martins (2004), apresentadas na seção acima, a três classes verbais de acordo com a valência do predicado verbal. A seguir, apresentamos nossa proposta preliminar de reclassificação dos verbos em Dâw de acordo com a valência dos verbos.

\begin{tabular}{|c|c|c|c|}
\hline & $\begin{array}{l}\text { Classe Intransitiva } \\
\text { (monoargumental) }\end{array}$ & $\begin{array}{l}\text { Classe transitiva } \\
\text { (biargumental) }\end{array}$ & $\begin{array}{l}\text { Classe } \\
\text { bitransitiva } \\
\text { (mais de dois } \\
\text { argumentos) }\end{array}$ \\
\hline \multirow{7}{*}{$\begin{array}{c}\text { Classes } \\
\text { verbais } \\
\text { propostas } \\
\text { por Martins } \\
\text { (2004) }\end{array}$} & Verbo ativo intransitivo & Verbo ativo transitivo & $\begin{array}{l}\text { Verbo ativo } \\
\text { bitransitivo }\end{array}$ \\
\hline & Verbo de processo & & \\
\hline & $\begin{array}{l}\text { Verbo estativo equativo } \\
\text { identificacional }\end{array}$ & & \\
\hline & $\begin{array}{c}\text { Verbo estativo equativo } \\
\text { existencial }\end{array}$ & & \\
\hline & $\begin{array}{c}\text { Verbo estativo } \\
\text { descritivo atributivo }\end{array}$ & & \\
\hline & $\begin{array}{c}\text { Verbo estativo } \\
\text { descritivo qualificativo }\end{array}$ & & \\
\hline & $\begin{array}{c}\text { Verbo estativo } \\
\text { descritivo posicional }\end{array}$ & & \\
\hline
\end{tabular}

Tabela 3.11. Classes verbais reanalisadas de acordo com o critério de valência 
Selecionamos alguns verbos de cada classe para realizar testes de mudança de valência (cf. capítulo 2) com o objetivo de encontrar evidências morfossintáticas que refutassem ou corroborassem nossa primeira hipótese de reclassificação. A realização desses testes nos mostrou comportamentos morfológicos importantes para a reanálise das classes verbais propostas por Martins (2004).

A seguir, apresentaremos os dados obtidos nesses testes e os resultados de nossas análises. O protocolo de elicitação e a metodologia empregada na realização dos testes encontram-se no capítulo 2.

\subsubsection{Classe dos verbos intransitivos}

Submetemos os verbos de valência intransitiva a cinco testes linguísticos.

i. Alternância causativo-incoativa;

ii. Causativização analítica;

iii. Identificação de raiz:
a. Adjetival;
b. Nominal;

iv. Cópulas de vários tipos;

v. Voz reflexiva.

$\mathrm{Na}$ tabela abaixo, apresentamos todos os verbos intransitivos testados (com a respectiva classificação de Martins, 2004) nos três trabalhos de campo realizados.

\begin{tabular}{c|l|l|l}
\hline Número & \multicolumn{1}{|c|}{ Verbo em Dâw } & \multicolumn{1}{c|}{ Tradução } & \multicolumn{1}{c}{$\begin{array}{c}\text { Classificação de } \\
\text { Martins (2004) }\end{array}$} \\
\hline 1 & wutd & Chegar & Ativo intransitivo \\
\hline 2 & baad & Virar & Ativo intransitivo \\
\hline 3 & 'eed & Virar & Ativo intransitivo \\
\hline 4 & bâar & Derramar & Ativo intransitivo \\
\hline 5 & pêt & Quebrar & Ativo intransitivo \\
\hline 6 & woox & Quebrar & Ativo intransitivo \\
\hline 7 & xop & Secar & Ativo intransitivo \\
\hline 8 & pô & Abrir & Ativo intransitivo \\
\hline 9 & tobuk & Fechar & Ativo intransitivo \\
\hline 10 & yapilu & Começar & Ativo intransitivo \\
\hline 11 & çêe & Espalhar & Ativo intransitivo \\
\hline 12 & rud & Derreter & Ativo intransitivo \\
\hline 13 & rũ & Terminar & Ativo intransitivo \\
\hline 14 & wâg & Balançar & Ativo intransitivo \\
\hline 15 & pâd & Rolar & Ativo intransitivo \\
\hline 16 & rã & Parar & Ativo intransitivo \\
\hline & & &
\end{tabular}




\begin{tabular}{|c|c|c|c|}
\hline 17 & leg & Apagar & Ativo intransitivo \\
\hline 18 & 'ox & Correr & Ativo intransitivo \\
\hline 19 & rôd & Sair & Ativo intransitivo \\
\hline 20 & ‘ãa & Dormir & Ativo intransitivo \\
\hline 21 & suuk & Caçar & Ativo intransitivo \\
\hline 22 & yelêew & Transformar-se & Ativo intransitivo \\
\hline 23 & kog’õogn & Desmaiar & Ativo intransitivo \\
\hline 24 & çeeb & Mudar & Ativo intransitivo \\
\hline 25 & ' $\mathrm{ub}$ & Acordar & Ativo intransitivo \\
\hline 26 & çom & Banhar & Ativo intransitivo \\
\hline 27 & win & Trabalhar & Ativo intransitivo \\
\hline 28 & nõx & Cair & Ativo intransitivo \\
\hline 29 & kũm & Afundar & Ativo intransitivo \\
\hline 30 & pôw' & Boiar & Ativo intransitivo \\
\hline 31 & pêg-saak & Crescer & Ativo intransitivo \\
\hline 32 & $\operatorname{stux}$ & Esfarelar & Ativo intransitivo \\
\hline 33 & 'õot & Chorar & Ativo intransitivo \\
\hline 34 & çâk & Pular & Ativo intransitivo \\
\hline 35 & roo' & Tossir & Ativo intransitivo \\
\hline 36 & 'ô & Rir & Ativo intransitivo \\
\hline 37 & âaw & Gritar & Ativo intransitivo \\
\hline 38 & yũmrũ & Cantar & Ativo intransitivo \\
\hline 39 & yam & Dançar & Ativo intransitivo \\
\hline 40 & yok & Nadar & Ativo intransitivo \\
\hline 41 & çâ & Saltar & Ativo intransitivo \\
\hline 42 & leep & Brilhar & Ativo intransitivo \\
\hline 43 & xaam & Vomitar & Ativo intransitivo \\
\hline 44 & bax & Suar & Ativo intransitivo \\
\hline 45 & bâay & Arrotar & Ativo intransitivo \\
\hline 46 & baak & Soluçar & Ativo intransitivo \\
\hline 47 & ratĩs & Espirrar & Ativo intransitivo \\
\hline 48 & kas & Estragar & Ativo intransitivo \\
\hline 49 & yum & Melhorar & Ativo intransitivo \\
\hline 50 & rãm xo & Andar & Ativo intransitivo \\
\hline 51 & xaw & Ferver & Processo \\
\hline 52 & beg & Clarear & Processo \\
\hline 53 & rõ & Queimar & Processo \\
\hline 54 & baax & Aparecer & Processo \\
\hline 55 & xub-sõk (rãm) & Estar triste & Estativo \\
\hline 56 & kub (rãm) & Estar escuro & Estativo \\
\hline 57 & rân (rãm) & Estar velho & Estativo \\
\hline 58 & duy (rãm) & Estar sujar & Estativo \\
\hline 59 & mẽn (rãm) & Ser curto & Estativo \\
\hline 60 & pêg (rãm) & Ser grande & Estativo \\
\hline 61 & ça (rãm) & Ser preto & Estativo \\
\hline 62 & lâk (rãm) & Ser magro & Estativo \\
\hline 63 & çii (rãm) & Ser azedo & Estativo \\
\hline 64 & dep (rãm) & Ser gordo & Estativo \\
\hline
\end{tabular}




\begin{tabular}{l|l|l|l}
\hline 65 & tâaw (rãm) & Estar bravo & Estativo \\
\hline 66 & kas (rãm) & Ser feio & Estativo \\
\hline 67 & muj (rãm) & Ser úmido & Estativo \\
\hline 68 & wê (rãm) & Estar molhado & Estativo \\
\hline 69 & sêj (rãm) & Estar cheio & Estativo \\
\hline 70 & 'wât (rãm) & Ser comprido & Estativo \\
\hline \multicolumn{2}{r}{ Tabela 3.12: Verbos intransitivos testados } \\
\hline
\end{tabular}

Em Dâw, a ordem default dos verbos intransitivos é SV. Não foram identificados morfemas de concordância e modo verbal nos paradigmas verbais testados. A única forma gramatical identificada nas sentenças intransitivas foi $o$ morfema livre $x a ̂ d$, que além de codificar aspecto (MARTINS, 2004:296), também codifica tempo pretérito. Todavia, o emprego de xâd como marca de tempo não está presente em todos os paradigmas elicitados, o que nos leva a hipotetizar que essa não é uma marca obrigatória, conforme podemos ver nos exemplos a seguir:

(6)

a) pu çâk $\quad$ p

sapo pulo VERB

'O sapo pula'

$\begin{array}{lll}\text { b) } & \text { pu çâk } & \emptyset \quad \text { xâd } \\ \text { sapo pulo } & \text { VERB ASPC/MV } \\ \text { 'O sapo pulou' } & \end{array}$

(7) a) Dâw xut roo' ø

gente macho tosse VERB

'O homem tosse'

b) Dâw xut roo' $\quad$ ø

gente macho tossir $\quad$ VERB ASPC/MV

'O homem tossiu' 


\section{Resultados dos testes}

\section{i) Alternância causativo-incoativa}

O teste de alternância causativo-incoativa mostrou-nos que em Dâw é possível dividir a classe dos verbos monoargumentais em duas subclasses:

i) Subclasse dos verbos alternantes: verbos intransitivos que alternam entre uma forma intransitiva e transitiva sem o acréscimo de nenhuma morfologia específica de aumento de valência, como visto nas sentenças em português 'o dia clareou' e 'o sol clareou o dia'. Os verbos presentes nessa subclasse estão presentes na tabela 3.12, itens 1 a 17.

ii) Subclasse dos verbos não-alternantes: verbos que não alternam entre uma forma intransitiva e transitiva sem morfologia específica. Os verbos presentes nessa subclasse estão presentes na tabela 3.12, itens 18 a 70 .

A subclasse dos verbos alternantes é formada por verbos intransitivos ativos, conforme a análise de Martins (2004). Já a subclasse dos verbos não-alternantes é formada pelos verbos intransitivos ativos, de processo e estativos.

A análise acerca dessas subclasses será discutida com mais detalhes no capítulo 5.

\section{ii) Causativização analítica}

Nenhum verbo intransitivo testado apresentou restrições quanto à causativização com dôo 'fazer', causativizador presente na língua ${ }^{5}$. Analisamos esse causativizador como um verbo leve, que adiciona um segundo argumento a uma sentença intransitiva (e como veremos mais adiante, um terceiro argumento em sentenças transitivas). $\mathrm{O}$ argumento introduzido é um agente ou causa, e o agente da sentença intransitiva passa a ser o objeto da construção causativa formada.

A análise acerca desse processo será discutida com mais detalhes no capítulo 5.

\section{iii) Identificação da raiz}

\footnotetext{
5 Além de dôo 'fazer', também identificamos outro tipo de causativizador na língua, a saber: waay 'mandar'. No entanto, não testamos a ocorrência desse causativizador com predicados verbais de várias classes. Waay 'mandar' será testado em trabalhos futuros.
} 
Além de testar alternâncias de valências dos verbos intransitivos, também testamos a formação dos predicados verbais a partir de raízes adjetivais e nominais.

\section{A. Raiz adjetival}

Testamos a possibilidade dos verbos estativos atributivos e descritivos serem formados a partir de uma raiz adjetival. Segundo Martins (2004), esses predicados verbais também podem modificar nomes, exprimindo o estado, o atributo e a posição de um nome. Nessa função, eles estariam sendo empregados como adjetivos, não como verbos. Desse modo, na análise da autora, a função verbal é a básica e a adjetival é a derivada.

Testamos 16 verbos estativos atributivos e descritivos em contextos verbais e adjetivais. Procuramos identificar a presença de morfologia nos contextos elicitados com o objetivo de identificar o direcionamento da derivação dessas formas, ou seja, se a forma básica é a verbal ou a adjetival.

A seguir, apresentamos os verbos estativos testados:

\begin{tabular}{c|l|l}
\hline Número & \multicolumn{1}{|c}{ Verbo em Dâw } & \multicolumn{1}{c}{ Tradução } \\
\hline 1 & xub sõk (rãm) & Estar triste \\
\hline 2 & kub (rãm) & Estar escuro \\
\hline 3 & rân (rãm) & Estar velho \\
\hline 4 & duy (rãm) & Estar sujo \\
\hline 5 & mẽn (rãm) & Ser curto \\
\hline 6 & pêg (rãm) & Ser grande \\
\hline 7 & ça (rãm) & Ser preto \\
\hline 8 & lâk (rãm) & Ser magro \\
\hline 9 & çii (rãm) & Ser azedo \\
\hline 10 & dep (rãm) & Ser gordo \\
\hline 11 & tâaw (rãm) & Estar bravo \\
\hline 12 & kas (rãm) & Ser feio \\
\hline 13 & muj (rãm) & Ser úmido \\
\hline 14 & wê (rãm) & Estar molhado \\
\hline 15 & sêj (rãm) & Estar cheio \\
\hline 16 & 'wât (rãm) & Ser comprido \\
\hline & & Tabela 3.13. Verbos estativos testados
\end{tabular}

Tabela 3.13. Verbos estativos testados

Observamos que os verbos analisados como estativos atributivos e descritivos por Martins (2004), quando usados na sua forma básica, sem o acréscimo de nenhum morfema preso ou livre, comportam-se como adjetivos, isto é, modificam nomes, 
contrariando as hipóteses de Martins (2004), que afirma que a forma básica desses sintagmas é a verbal. Nos exemplos (8) e (9) mostramos dois contextos em que o constituinte, analisado por Martins (2004) como verbo, ocorre como adjetivo.

(8)
a) yum mẽn
roupa curto

'A roupa curta'

b) yun mẽn nõox

roupa curto cair

'A roupa curta caiu'
(9) a) Dâw xut dep
gente macho gordo
'O homem gordo'
b) Dâw xut dep wutd
gente macho gordo chegar
'O homem gordo chegou'

As formas apresentadas em (8a) e (9a) também podem ter uma leitura estativa, como a apresentada abaixo:

(10) yum mẽn ø

roupa curto $\mathrm{COP}$

'A roupa está/é curta'

\section{(11) Dâw xut dep ø \\ gente macho gordo COP \\ 'O homem está/é gordo'}

Isso ocorre, pois as cópulas 'ser' e 'estar' em Dâw são vazias, o que pode gerar ambiguidade entre as estruturas nominais (exemplos 8 e 9) e estativas (exemplos 10 e 11). Discutiremos com mais detalhes a diversidade de uso das cópulas com os adjetivos nas próximas seções.

A verbalização desses adjetivos ocorre por meio de uma cópula, a saber, rãm 'ir', que toma como complemento o adjetivo. Assim, como a forma verbal é a forma 
marcada, isto é, é aquela que recebe morfologia, analisámo-la como uma derivação da forma não-marcada, ou seja, o adjetivo.

Abaixo, apresentamos alguns exemplos da formação de verbos a partir de adjetivos em Dâw.

yun mẽn rãm
roupa curto ficar

'A roupa encurtou (Lit.: A roupa ficou curta)'

b) yun mẽn rãm-ẽr

roupa curto ficar-NEG

'A roupa não encurtou (Lit.: A roupa não ficou curta)'

(13) a) Dâw xut dep rãm

gente macho gordo ficar

'O homem engordou (Lit.: O homem ficou gordo)'

b) Dâw xut dep rãm-ẽr

gente macho gordo ficar-NEG

'O homem não engordou (Lit.: O homem não ficou gordo)'

A elicitação de sentenças negadas, como mostram (12b) e (13b), objetivou forçar a produção de um predicado verbal, uma vez que o sufixo de negação $\{-\tilde{e} r\}$ é um afixo verbal que aparece adjacente ao verbo nas sentenças. No entanto, nos dados elicitados, ele também pôde aparecer adjacente ao adjetivo, como vemos abaixo:

(14) yun mẽn-ø-ẽr

roupa curto-COP-NEG

'A roupa não é/está curta'

(15) Dâw xut dep-ø-ẽr

gente macho gordo-COP-NEG

'O homem não é/está gordo'

Como discutimos anteriormente, a formação do sintagma adjetival é ambígua, pois pode ter uma leitura estativa, na qual estaria presente uma cópula vazia 'ser' ou 'estar', como mostramos nos exemplos (10) e (11). Dessa forma, nos ambientes 
mostrados acima, o sufixo de negação estaria no domínio da cópula vazia, e não propriamente do adjetivo, por isso que a leitura gerada continua sendo a verbal nos exemplos mostrados anteriormente.

Tendo em vista os padrões morfossintáticos encontrados na elicitação dos verbos estativos atributivos e descritivos, podemos afirmar que as formas apresentadas como predicados verbais por Martins (2004) são adjetivos e essas formas são usadas como predicados apenas quando elas são complemento da cópula rãm 'ir' ou da cópula zero.

Rãm 'ir'possui uma forma cognata em Hup (língua que também pertence à família Nadahup), a saber, ham 'ir'. Segundo Epps (2005), em Hup, ham 'ir' pode aparecer como cópula em predicados adjetivais, que não são marcados por morfemas gramaticais. Nessas construções, a cópula teria a função de carregar esses morfemas, como aspecto e tempo, por exemplo. Segundo a autora, a cópula só pode acompanhar um predicado adjetival se esse predicado for nominalizado e realizado na sintaxe como um predicado nominal. A nominalização do predicado adjetival é realizada pelo pronome de terceira pessoa do singular (tih), como podemos ver no exemplo abaixo.

(16) yi-d'õh yúp tih=páy=d'əh ham-ní-h este.ITG-PL este.ITG $3 \mathrm{sg}=\mathrm{mau}=\mathrm{PL} \quad$ ir-INFR2-DECL

'Estas pessoas tornaram-se más'

(EPPS, 2005: 937)

Assim, acreditamos que em Dâw, rãm 'ir' é uma cópula que toma como complemento um adjetivo. Desse modo, uma construção como duy rãm 'estar / ser sujo' possui uma semântica estativa, o que explicaria o fato desse verbo não poder alternar entre as formas causativa e incoativa. Essa questão será aprofundada no capítulo 5.

Assim, divergimos da análise de Martins (2004), que analisa as formas adjetivais sem cópula como predicados verbais. A estrutura predicadora só é formada quando a cópula toma o adjetivo como complemento.

\section{B. Raiz nominal}

Também testamos a formação de alguns verbos intransitivos a partir de raízes nominais.

A seguir, apresentamos os verbos intransitivos testados: 


\begin{tabular}{c|l|l}
\hline Número & \multicolumn{1}{c|}{ Verbo em Dâw } & \multicolumn{1}{c}{ Tradução } \\
\hline 1 & sux & Esfarelar \\
\hline 2 & 'õot & Chorar \\
\hline 3 & çâk & Pular \\
\hline 4 & roo' & Tossir \\
\hline 5 & 'ô & Rir \\
\hline 6 & âaw & Gritar \\
\hline 7 & yũmrũ & Cantar \\
\hline 8 & yam & Dançar \\
\hline 9 & yok & Nadar \\
\hline 10 & çâ & Saltar \\
\hline 11 & leep & Brilhar \\
\hline 12 & xaam & Vomitar \\
\hline 13 & bax & Suar \\
\hline 14 & bâay & Arrotar \\
\hline 15 & baak & Soluçar \\
\hline 16 & ratĩs & Espirrar \\
\hline & \multicolumn{2}{c}{ Tabela 3.14: Verbos denominais testados }
\end{tabular}

Foram testados 16 verbos denominais em Dâw. Procuramos identificar a presença de morfologia nos contextos elicitados com o objetivo de identificar o direcionamento da derivação dessas formas, ou seja, se a forma básica é a verbal ou nominal.

Abaixo, apresentamos os dados elicitados dos verbos 'õot 'chorar' e çâk 'pular'. Os outros 13 verbos seguem o mesmo padrão morfológico dos três verbos supracitados.

\section{Construção nominal}

(17) a) Dâw tee 'õot

gente filho choro

'O choro da criança'

b) Dâw tee 'õot rã

gente filho choro parar

'O choro da criança parou'

(18) a) pâ çâk

sapo pulo

'O pulo do sapo' 


b) Dâw xut wây pâ çâk
gente macho ver sapo pulo
'O homem viu o pulo do sapo'

Contexto verbal

$\begin{array}{ll}\text { (19) a) Dâw tee 'õot-ø } \\ & \text { gente filho choro-VERB } \\ & \text { 'A criança chorou' } \\ \text { b) } & \text { Dâw tee 'õot- } \varnothing-\tilde{e} \mathbf{r} \\ & \text { gente filho choro-VERB-NEG } \\ & \text { 'A criança não chorou' }\end{array}$

(20) a) pâ çâk-ø

sapo pulo-VERB

'O sapo pula'
b) pâ çâk-ø-ẽr
sapo pulo-VERB-NEG
'O sapo não pulou'

Os verbos testados possuem uma forma nominal cognata que possivelmente é a raiz da formação verbal. Não encontramos morfemas verbalizadores nas construções testadas. Conforme veremos adiante com mais detalhes no capítulo 5, acreditamos que a formação desses verbos ocorra via conflation (HALLE \& KEYSER, 2002:13), um processo sintático no qual a matriz fonológica do complemento de um núcleo verbal é introduzida na matriz fonológica vazia do núcleo que seleciona o complemento. Esses verbos não participam da alternância causativo-incoativa, o que é esperado pela literatura supracitada. Verbos denominais possuem uma estrutura argumental que os impede de alternar livremente entre uma forma causativa e incoativa. Essas e outras questões serão aprofundadas no capítulo 5. 


\section{iv) Cópulas de vários tipos}

No terceiro trabalho de campo realizado nessa pesquisa, testamos o emprego das cópulas e os sentidos que elas podem ter com os adjetivos em Dâw. Como vimos nas seções anteriores, em Dâw, os verbos deadjetivais são formados por meio de cópulas que tomam como complemento um adjetivo. Dessa forma, testamos o 'sabor' que algumas cópulas podem ter na formação desses tipos de verbos.

Os adjetivos testados foram:

\begin{tabular}{c|l|l}
\hline Número & \multicolumn{1}{|c|}{ Adjetivo em Dâw } & \multicolumn{1}{c}{ Tradução } \\
\hline 1 & xub-sõk & Triste \\
\hline 2 & kub & Escuro \\
\hline 3 & rân & Velho \\
\hline 4 & duy & Sujar \\
\hline 5 & mẽn & Curto \\
\hline 6 & pêg & Grande \\
\hline 7 & ça & Preto \\
\hline 8 & lâk & Magro \\
\hline 9 & çii & Azedo \\
\hline 10 & dep & Gordo \\
\hline 11 & tâaw & Bravo \\
\hline 12 & kas & Feio \\
\hline 13 & muj & Úmido \\
\hline 14 & wê & Molhado \\
\hline 15 & sêj & Cheio \\
\hline 16 & wât & Comprido \\
\hline & \multicolumn{2}{|}{ Tabela 3.15. Lista de adjetivos testados } \\
\hline & &
\end{tabular}

As cópulas testadas:

i. Estar - pud; rẽd;

ii. $\quad$ Ser - rẽd;

iii. Ficar-rãm, pitar;

iv. Tornar-se - yelêew;

v. Ficará - rãm na;

vi. Ficar sempre - rãm ti; we.r

Os contextos nos quais as cópulas foram elicitadas:

i. X está sujo, triste, velho;

ii. $\mathrm{X}$ é sujo, triste, velho;

iii. $\mathrm{X}$ ficou sujo, triste, velho;

iv. $\mathrm{X}$ tornou(-se) sujo, triste, velho; 
v. X ficará sujo, triste, velho;

vi. $\mathrm{X}$ fica sempre sujo, triste, velho.

Nesses contextos, as cópulas estar e ser apresentaram-se como vazias em todas as ocorrências elicitadas.

$$
\begin{array}{ll}
\text { (21) } & \text { yun duy } \quad \begin{array}{l}
\quad \\
\text { roupa suja COP } \\
\text { 'A roupa é/está suja' }
\end{array} \\
\text { (22) } & \text { woor } \quad \text { xub-sõk } \emptyset \\
& \text { tukano triste COP } \\
& \text { 'O tukano é/está triste' }
\end{array}
$$

Em alguns exemplos, as cópulas pud 'estar' (exemplo 23) e rẽd 'ser e estar' (exemplo 24) atribuíram à sentença a mesma leitura estativa atribuída pelas cópulas vazias. A cópula rẽd, diferentemente de $p u d$, antecede o adjetivo.

$$
\begin{aligned}
& \text { Tor peg pud } \\
& \text { porco grande estar } \\
& \text { 'O porco está grande' }
\end{aligned}
$$

$\begin{array}{lcc}\text { Woor } & \text { rẽd } & \text { dep } \\ \text { Tukano } & \text { ser/estar } & \text { gordo } \\ \text { 'O tukano é/está gordo' } & \end{array}$

A cópula 'ficar' foi realizada na língua como rãm em todos os dados elicitados.

$$
\begin{aligned}
& \text { Dâw xut kas rãm } \\
& \text { gente macho feio ficar } \\
& \text { 'O homem ficou feio' }
\end{aligned}
$$

Houve algumas ocorrências da cópula pitar nesse mesmo ambiente.

$$
\begin{aligned}
& \text { Dâw xut tâaw pitar } \\
& \text { gente macho bravo ficar } \\
& \text { 'O homem ficou bravo' }
\end{aligned}
$$

A cópula 'tornar-se' foi realizada pelo verbo yelêew, que na língua também significa 'transformar-se'.

$$
\begin{array}{lll}
\text { Yun yelêew } & \text { kub } \\
\text { roupa tornar-se } & \text { escuro }
\end{array}
$$


'A roupa tornou-se escura'

A cópula no tempo futuro 'ficará' foi realizada na língua pela composição da cópula rãm e o morfema livre que categoriza futuro nã , marcador de tempo futuro (Martins, 2004:284). Essa locução também é traduzida pelos informantes como 'vai estar'.

$$
\begin{aligned}
& \text { Dâw xut tâaw rãm nã } \\
& \text { gente macho bravo ficar FUT.E } \\
& \text { 'O homem vai ficar bravo' }
\end{aligned}
$$

Por fim, a composição temporal 'ficar sempre' foi traduzida pelos informantes como wer ou pela forma composta rãm ti.

$\begin{array}{llll}\text { Weed } & \text { çii } & \varnothing & \text { wer } \\ \text { Comida } & \text { azeda } & \text { COP } & \text { sempre }\end{array}$

'A comida fica sempre azeda (Lit.: A comida é sempre azeda)'

$$
\begin{aligned}
& \text { Yun ça rãm ti } \\
& \text { Roupa preto ficar sempre } \\
& \text { 'A roupa fica sempre preta' }
\end{aligned}
$$

A segunda etapa desse teste foi a construção de sentenças intransitivas e transitivas com as cópulas elicitadas acima. Os informantes da língua julgaram a (a)gramaticalidade das sentenças formadas.

O objetivo desse teste foi o de verificar se as cópulas que ocorrem com adjetivos também podem ocorrer com verbos intransitivos e transitivos. As restrições de ocorrência dessas cópulas com esses predicados nos ajudou a distinguir subclasses de verbos intransitivos e a mostrar que os verbos analisados por Martins (2004) como estativos são, de fato, adjetivos na língua.

A seguir, apresentamos os verbos testados:

\begin{tabular}{c|l|l|l}
\hline Número & \multicolumn{1}{|c|}{ Verbo em Dâw } & \multicolumn{1}{c}{ Tradução } & \multicolumn{1}{c}{ Classe verbal } \\
\hline 1 & wĩnh & Trabalhar & Verbo intransitivo \\
\hline 2 & rôd & Sair & Verbo intransitivo \\
\hline 3 & ãa & Dormir & Verbo intransitivo \\
\hline 4 & suuk & Caçar & Verbo intransitivo \\
\hline 5 & 'tb & Acordar & Verbo intransitivo \\
\hline 6 & wutd & Chegar & Verbo intransitivo \\
\hline 7 & xop & Secar & Verbo intransitivo \\
\hline 8 & pô & Abrir & Verbo intransitivo \\
\hline 9 & tobuk & Fechar & Verbo intransitivo \\
\hline
\end{tabular}




\begin{tabular}{l|l|l|l}
\hline 10 & yapilu & Começar & Verbo intransitivo \\
\hline 11 & Rõk & Cortar & Verbo transitivo \\
\hline 12 & Kâs & Morder & Verbo transitivo \\
\hline 13 & Yũt & Matar & Verbo transitivo \\
\hline 14 & Weed & Comer & Verbo transitivo \\
\hline 15 & Ya' & Assar & Verbo transitivo \\
\hline \multicolumn{2}{l}{ Tabela 3.16: Verbos intransitivos e transitivos testados com vários tipos de cópulas } \\
\hline
\end{tabular}

Os verbos intransitivos listados do item 1 a 5 pertencem à subclasse dos verbos alternantes, e os verbos listados do item 6 a 10 pertencem à subclasse dos verbos nãoalternantes. Apresentamos os resultados dos testes acima descritos com cada cópula elicitada.

\section{Pud 'estar'}

$P \mathfrak{t} d$ gerou sentenças gramaticais com verbos intransitivos e transitivos, todavia em todas as sentenças geradas, pud não ocorreu como uma cópula, mas como um advérbio de intensidade que pode denotar 'muito' ou 'mesmo'.

$$
\begin{array}{ll}
\text { Dâw xut wĩnh } & \text { pud } \\
\text { gente macho trabalhar } & \text { ADV.INT } \\
\text { 'O homem trabalha muito' } &
\end{array}
$$

$$
\begin{array}{lll}
\text { Dâw } & \text { xut 'ub } & \text { pud } \\
\text { gente } & \text { macho acordar } & \text { ADV.INT }
\end{array}
$$

\begin{tabular}{|c|c|c|}
\hline Yam & kâs pud & buuy-zuty' \\
\hline cachorro & morder ADV.INT & homem branco-MDO \\
\hline
\end{tabular}

'O homem acorda muito (O homem acorda várias vezes)'

$$
\begin{aligned}
& \text { Dâw xut rõk pud tor } \\
& \text { gente macho cortar ADV.INT porco } \\
& \text { 'O homem cortou mesmo o porco' }
\end{aligned}
$$


Rẽd 'ser'

A presença da cópula rẽd 'ser' antes de predicados verbais intransitivos gerou sentenças agramaticais com todos os verbos testados ${ }^{6}$.

(35)

$\begin{array}{ccc}* \text { Woor } & \text { rẽd } & \text { rôd } \\ \text { tukano } & \text { ser } & \text { sair }\end{array}$

(36)

$\begin{array}{lll}* \text { Tir } & \text { rẽd } & \text { ãa } \\ \text { 3PL } & \text { ser } & \text { dormir }\end{array}$

*Dâw xut rẽd weed baa'
gente macho ser comer beiju

\section{Rãm 'ir/ficar/ser'}

Com alguns verbos intransitivos e transitivos, rãm foi empregado com o sentido de 'ir', gerando locuções verbais, como as que seguem abaixo:

(39)

Buuy suuk rãm
homem branco caçar ir
'O homem branco foi caçar'

(40)

$\begin{array}{ll}\text { Dâw xut wĩnh } & \text { rãm } \\ \text { gente macho trabalhar } & \text { ir } \\ \text { 'O homem foi trabalhar' }\end{array}$

Dâw xut ya' rãm tor
gente macho assar ir porco
'O homem foi assar o porco'

\footnotetext{
${ }^{6}$ Nos testes de produção de sentenças, rẽd foi produzida pelos informantes antes do verbo. Devido a essa característica, nos testes de julgamento de agramaticalidade, construímos sentenças intransitivas e transitivas nas quais a cópula rẽd antecede o predicado verbal.
} 
A locução verbal foi gerada apenas com uma subclasse de verbos intransitivos, a saber, a subclasse dos verbos não-alternantes e com os verbos transitivos. Com os verbos não alternantes, a inserção de rãm gerou sentenças incoativas com uma leitura télica.

$$
\begin{array}{ll}
\text { Daad yapilu } & \text { rãm } \\
\text { aula começar ir } & \text { 'A aula já começou', }
\end{array}
$$

$$
\begin{aligned}
& \text { Dâw xut wutd rãm } \\
& \text { gente macho chegar ir/ficar } \\
& \text { 'O homem chegou/ já chegou', }
\end{aligned}
$$

Esses dados revelam que a inserção de rãm em sentenças intransitivas distingue subclasses de verbos intransitivos, subclasses já identificadas por meio dos testes de alternância causativo-incoativa. Ou seja, verbos que não alternam formam locuções verbais com rãm que nesses contextos é um auxiliar cujo significado é 'ir'. Com verbos que alternam, isso não ocorre e rãm possui leitura aspectual télica.

Segundo Martins (2004), rãm é um verbo que deriva marca de aspecto télico que aparece sufixado ao predicado verbal ${ }^{7}$. Como afixo, sua forma é realizada como $\{-\tilde{a} m\}$. Para Martins (2004), esse morfema também funciona como verbalizador e derivaria verbos de processo (valência intransitiva), como podemos ver nos exemplos a seguir:

$$
\begin{array}{lllll}
\text { 'a-bug tir } & \text { duu' } & \text { putd } & \text {-ãm } \\
\text { nesse-aí } & 3 S G \quad \text { tarde } & \text { ser Intensif. } & \text {-TEL } \\
\text { 'Daí, foi entardecendo' } &
\end{array}
$$

(MARTINS, 2004: 295)

$$
\begin{array}{lll}
\text { tir } \quad \text { çêm } & \text {-ãm } \\
\text { 3SG noite } & \text {-TEL } \\
\text { 'Anoiteceu' } &
\end{array}
$$

(MARTINS, 2004: 295)

Não analisamos o verbo rãm como verbalizador de verbos intransitivos, pois, como observamos nos exemplos (46) e (47), os mesmos predicados verbais intransitivos mostrados em (42) e (43) são verbos intransitivos sem a presença de rãm na sentença, o

\footnotetext{
${ }^{7}$ Diferentemente das demais marcas de aspecto, o morfema télico é o único pode ser sufixado ao verbo, segundo Martins (2004).
} 
que refuta a ideia de que rãm é responsável pela formação de raízes verbais intransitivas.

\section{Daad yapilu}

aula começar

'A aula começou'

(47)

\section{Tir wutd \\ 3PL chegar}

'Ele chegou'

Acreditamos que rãm codifica informações aspectuais, como analisado por Martins (2004), todavia, diferentemente da autora, que afirma que o verbo deriva um morfema de aspecto télico, $\{-\tilde{a} m\}$; acreditamos que o verbo rãm, por si só, pode derivar uma leitura télica.

\section{Pitar 'ficar'}

A presença da cópula pitar 'ficar', diferentemente de rãm, gerou sentenças agramaticais com todos os verbos testados.

$$
\begin{aligned}
& \text { *Dâw xut wutud pitar } \\
& \text { gente macho chegar ficar }
\end{aligned}
$$

$$
\begin{array}{cc}
* \text { Woor rôd } & \text { pitar } \\
\text { tukano sair } & \text { ficar }
\end{array}
$$

\begin{tabular}{|c|c|c|c|}
\hline$*$ Yam & kâs & & buuy-ũuy' \\
\hline cachorro & morder & ficar & homem branco-MDO \\
\hline
\end{tabular}

Esse resultado nos mostra que, apesar de serem sinônimas, as cópulas pitar e rãm apresentam traços estruturais distintos que permitem que cada uma delas ocorra em um ambiente sintático distinto. 


\section{Yelêew 'tornar-se'}

A presença da cópula yelêew 'tornar-se' sucedendo predicados verbais intransitivos e transitivos gerou sentenças agramaticais com todos os verbos testados.

$$
\begin{array}{lll}
\text { *Buuy } & \text { suuk } & \text { yelêew } \\
\text { homem branco } & \text { caçar } & \text { torna-se }
\end{array}
$$

$\begin{array}{lll}\text { *Dâw xut } & \text { ub } & \text { yelêew } \\ \text { gente macho } & \text { acordar } & \text { tornar-se }\end{array}$

$\begin{array}{clll}\text { *Dâw xut yũt } & \text { yelêew } & \text { taax } \\ \text { gente macho matar } & \text { tornar-se } & \text { anta }\end{array}$

\section{Rãm nã 'ficará'}

Rãm nã gerou sentenças gramaticais com todos os verbos testados. Todavia, diferentemente da leitura gerada com adjetivos, na qual as duas cópulas foram traduzidas como 'vai ficar'; com verbos intransitivos e transitivos, a cópula rãm e o morfema livre de tempo futuro na foram traduzidos apenas como 'vai', com o sentido de futuro.

$\begin{array}{ll}\text { Woor rôd rãm } & \text { nã } \\ \text { tukano sair ir } & \text { FUT.E } \\ \text { 'O tukano vai sair' } & \end{array}$

(55) Tir ãa rãm nã

3PL dormir ir FUT.E

'Ele vai dormir'

(56) Dâw xut weed rãm nã baa'

gente macho comer ir FUT.E beiju

'O homem vai comer o beiju' 
Wer 'fica sempre'

De forma semelhante ao que foi visto com os adjetivos, com sentenças intransitivas e transitivas, wer apresentou-se como um advérbio cujo significado é 'sempre'. A diferença entre as duas sentenças - sintagmas adjetivais e predicados verbais - encontra-se no fato de que nesta há um verbo pronunciado, e naquela há uma cópula vazia, não pronunciada. Em ambos os casos, no entanto, o advérbio wer 'sempre’ aparece após o verbo (nulo ou não), na última posição da sentença.

Tir ãa wer

3PL dormir sempre

'Ele sempre dorme'

Buuy $\begin{aligned} & \text { suuk } \\ & \text { homem branco caçar }\end{aligned}$
'O hempre
homem branco sempre caça'

Dâw xut ya' wer tor
gente macho assar sempreporco
'O homem sempre assa o porco'

\section{Rãm ti 'ficar sempre'}

A composição temporal rãm ti 'ficar sempre' gerou sentenças gramaticais com todos os verbos testados.

$\begin{array}{llll}\text { Dâw xut wĩnh } & \text { rãm } & \text { ti } \\ \text { gente macho trabalhar } & \text { ir } & \text { sempre } \\ \text { 'O homem sempre trabalha' } & & \end{array}$

(61)

$\begin{array}{lrl}\text { Buuy } & \text { suuk rãm ti } \\ \text { homem branco } & \text { caçar ir } & \text { sempre } \\ \text { 'O homem branco sempre vai caçar' }\end{array}$


(62)

$$
\begin{array}{llll}
\text { Dâw } & \text { xut yũt rãm } & \text { ti } \\
\text { gente } & \text { macho matar } & \text { ir } & \text { sempre }
\end{array}
$$

'O homem sempre vai matar a anta'

As restrições de ocorrência das cópulas e das locuções verbais com os verbos intransitivos e transitivos mostraram-nos que, de fato, os verbos analisados por Martins (2004) como estativos são adjetivos na língua. Como adjetivos, podem ocorrer com todas as cópulas testadas, diferente dos verbos intransitivos e transitivos testados. Isso nos mostra que os adjetivos possuem propriedades distintas das outras classes verbais na língua Dâw, refutando a hipótese de Martins (2004) de que as raízes em questão são verbos estativos.

\section{v) Voz reflexiva}

Em Dâw, a voz reflexiva é uma construção transitiva, pois ela exige a presença de dois argumentos correferenciais, isto é, o sujeito e o objeto (pronome reflexivo que se apresenta na sua forma oblíqua). Diante disso, seu uso está restrito a predicados transitivos que possuam ambos os argumentos.

Tendo em vista essa propriedade da voz reflexiva, testamos a possibilidade de alguns verbos intransitivos aparecerem em construções reflexivas, objetivando identificar morfologia que diferencie classes verbais intransitivas e transitivas. Nessa perspectiva, verbos intransitivos não podem formar sentenças reflexivas em Dâw. Assim, verbos que gerarem sentenças reflexivas agramaticais são analisados como predicados basicamente intransitivos.

$\mathrm{Na}$ tabela abaixo, apresentamos os verbos intransitivos testados:

\begin{tabular}{c|l|l}
\hline Número & \multicolumn{1}{|c|}{ Verbo em dâw } & \multicolumn{1}{c}{ Tradução } \\
\hline 1 & Xop & Secar \\
\hline 2 & Bâad & Virar \\
\hline 3 & Wâg & Balançar \\
\hline 4 & Wuttd & Chegar \\
\hline 5 & Woox & Quebrar \\
\hline 6 & Ox & Correr \\
\hline 7 & Wĩnh & Trabalhar \\
\hline 8 & Rôd & Sair \\
\hline 9 & Rãm xô & Andar \\
\hline 10 & Suuk & Caçar \\
\hline 11 & Yellêw & Transformar-se \\
\hline 12 & Çeeb & Mudar \\
\hline
\end{tabular}




\begin{tabular}{l|l|l}
\hline 13 & $\mathrm{ub}$ & Acordar \\
\hline 14 & Beg & Clarear \\
\hline 15 & Rõ & Queimar \\
\hline \multicolumn{2}{c}{ Tabela 3.17: Verbos intransitivos testados nas construções reflexivas } \\
\hline
\end{tabular}

Os verbos listados do item 1 a 5 pertencem à subclasse dos verbos alternantes, e os verbos listados do item 6 a 15 pertencem à subclasse dos verbos não-alternantes.

Dos 15 verbos testados, apenas 3 verbos formaram sentenças reflexivas gramaticais, a saber: xop 'secar', bâad 'virar' e wâg 'balançar', todos verbos alternantes. Os outros verbos formaram sentenças reflexivas agramaticais.

$$
\begin{array}{lll}
\tilde{\mathbf{A r}} & \mathbf{x o p} & \text { mũnh } \\
\text { 1PS } & \text { secar } & 1 \mathrm{PS} . \mathrm{OBL}
\end{array}
$$

'Eu me sequei'

$$
\begin{array}{lll}
\text { Ãr } & \text { wâg } & \text { mũnh } \\
\text { 1PS } & \text { balançar } & \text { 1PS.OBL }
\end{array}
$$

'Eu me balancei'

$$
\begin{array}{lll}
* \tilde{A} \mathbf{r} & \mathbf{o x} & \text { mũnh } \\
1 \mathrm{PS} & \text { correr } & \text { 1PS.OBL }
\end{array}
$$

$\begin{array}{lll}* \tilde{A} \mathbf{r} & \text { wĩnh } & \text { mũnh } \\ 1 \mathrm{PS} & \text { trabalhar } & \text { 1PS.OBL }\end{array}$

Dos doze verbos que formaram sentenças reflexivas agramaticais, seis deles só puderam configurar construções reflexivas gramaticais após serem causativizados pelo causativizador dôo 'fazer', como podemos ver abaixo:

$$
\begin{array}{llll}
\tilde{\mathbf{A}} \mathbf{r} & \mathbf{x u p} \quad \text { dôo } \quad \text { rõ } & \text { mũnh } \\
\text { 1PS } & \text { mesmoCAUS queimar } & \text { 1PS.OBL }
\end{array}
$$

'Eu mesmo me fiz queimar' 
(69)

$\begin{array}{llll}\tilde{\mathbf{A}} \mathbf{r} & \mathbf{x u p} & \mathbf{d o ̂} \mathbf{c} \text { ' } \mathbf{u b} & \mathbf{m} \tilde{\mathbf{u} n h} \\ 1 \mathrm{PS} & \text { mesmo } & \text { CAUS acordar } & \text { 1PS.OBL }\end{array}$

'Eu mesmo me fiz acordar'

Os outros seis verbos formaram construções reflexivas agramaticais mesmo após serem causativizados.

$$
\begin{array}{ll}
* \tilde{A} \mathbf{r} & \text { xup dôo beg mũnh } \\
\text { 1PS } & \text { mesmoCAUS clarear } 1 \text { PS.OBL }
\end{array}
$$

$$
\begin{array}{cllll}
* \tilde{A} \mathbf{r} & \text { xup dôo suuk } & \text { mũnh } \\
1 P S & \text { mesmoCAUS caçar } & 1 P S . O B L
\end{array}
$$

Acreditamos que os verbos que geraram sentenças agramaticais são de fato verbos intransitivos, pois, como vimos anteriormente, em Dâw, sentenças reflexivas possuem valência transitiva, uma vez que exigem a presença de dois argumentos correferenciais.

Ainda não está claro para nós se os verbos que geraram sentenças gramaticais podem ser considerados verbos basicamente transitivos, pois não é possível saber se esses predicados são basicamente transitivos ou passaram pelo processo de transitivização, uma vez que não há morfologia explicita desse processo de aumento de valência em Dâw.

\subsubsection{Classe dos verbos transitivos}

Submetemos os verbos de valência transitiva a cinco testes linguísticos.

i. Apagamento de constituintes;

ii. Causativização analítica;

iii. Construção de sentenças:
a. Passivas;
b. Reflexivas;
c. Médias;
d. Incoativas.

iv. Uso de morfologia de objeto - MDO

v. Cópulas de vários tipos. 
Os resultados do teste de uso de cópulas com predicados transitivos já foram discutidos na seção anterior. Os resultados dos testes de redução de valência (passivas, reflexivas, médias e incoativas) são apresentados no capítulo 6 . Os resultados do uso de morfologia de objeto são apresentados no capítulo7.

A seguir, apresentamos os 15 verbos transitivos testados nos três trabalhos de campo realizados:

\begin{tabular}{c|l|l}
\hline Número & \multicolumn{1}{|c|}{ Verbo em dâw } & \multicolumn{1}{c}{ Tradução } \\
\hline 1 & Rõk & Cortar \\
\hline 2 & Kâs & Morder \\
\hline 3 & Yũt & Matar \\
\hline 4 & Wây & Ver \\
\hline 5 & Mũm & Abraçar \\
\hline 6 & Çũnh & Beijar \\
\hline 7 & Ya & Assar \\
\hline 8 & Xa & Cozinhar \\
\hline 9 & Âg & Beber \\
\hline 10 & Rề & Cavar \\
\hline 11 & Nee & Fazer \\
\hline 12 & Rõoy & Focar \\
\hline 13 & 'ũum & Bater (genérico) \\
\hline 14 & Weed & Comer \\
\hline 15 & Paar & Saber \\
\hline & \multicolumn{2}{|l}{ Tabela 3.18: Verbos transitivos testados } \\
\hline
\end{tabular}

Em Dâw, a ordem default dos verbos transitivos é SVO. À semelhança das construções intransitivas, não foram identificados morfemas de concordância e modo verbal nos paradigmas verbais testados. Quanto à categorização de tempo dos verbos, o tempo presente não foi marcado morfologicamente (exemplos 72b, 73b, 74b). Em alguns dados, a leitura de pretérito foi dada pelo morfema livre dâr (exemplo 74), mas, na maioria das ocorrências, os falantes não distinguiram morfologicamente tempos passado e presente (exemplos 72a, 73a, 74a). O tempo futuro foi marcado pelo morfema livre nã, marcador de tempo identificado por Martins (2004) (exemplos 72c, $73 \mathrm{c}, 74 \mathrm{c})$.
a) Yam $\begin{array}{ll}\text { yũt } & \text { nũ-ũuy' } \\ \text { matar } & \text { rato-MDO }\end{array}$
cachorro
matou o rato'
b) Yam
yũt nũ-üuy'
cachorro
matar rato-MDO
'O cachorro mata o rato' 

c) Yam
yũt
nã nũ-ũuy'
cachorro
matar
FUT.E rato-MDO
'O cachorro vai matar o rato'

(73)

a) Dâw xut wây pũug

gente macho ver porco-espinho

'O homem viu o porco-espinho'

b) Dâw xut wây pũug

gente macho ver porco-espinho

'O homem vê o porco-espinho'
c) Dâw xut wây
nã pũug
gente macho ver
FUT.E porco-espinho

'O homem vai ver o porco-espinho'

(74)
a) Dâw xut bâa
dâr
naax
gente macho derramar
PONT/MV
água
'O homem derramou água'
b) Dâw xut bâa naax
gente macho derramar água
'O homem derrama água'

\section{Resultados dos testes}

\section{i) Apagamento de constituintes}

Com relação ao pagamento de um dos argumentos do verbo (sujeito ou objeto), observamos pelos dados elicitados que é possível apagar objetos diretos de predicados verbais transitivos (exemplo 78b e 79b). O apagamento de sujeito gera agramaticalidade à sentença (exemplo 78c e 79c). Disso decorre o fato de que possivelmente Dâw não seja uma língua pro-drop, isto é, uma língua que permite sujeito nulo. Todavia, devido 
ao comportamento em relação ao apagamento de objetos, pode-se hipotetizar que Dâw é uma língua objetc-drop. Contudo, é preciso checar se objetos podem ser apagados de modo geral, ou apenas quando são tópicos.
$\mathbf{x H}$
cachorro verdadeiro
'A onça mordeu o homem'
a) Yam
kâs Dâw xut-ũuy'
morder gente macho-MDO
b) Yam
$\mathbf{X H}$
kâs
cachorro verdadeiro morder
'A onça mordeu'
c) *Kâs dâw xut-ũuy'
matar gente macho-MDO
(76)
a) Dâw xut yũt yam x-ũuy'
gente macho matar cachorro verdadeiro-MDO
'O homem matou a onça'

b) Dâw xut yũt

gente macho matar

'O homem matou'

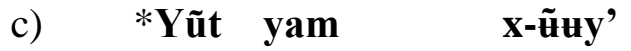 \\ matar cachorro verdadeiro-MDO \\ $\mathrm{O}$ apagamento do sujeito gera uma sentença gramatical apenas quando
} empregado no modo imperativo.

\begin{tabular}{|c|c|c|}
\hline d) & $\begin{array}{l}\text { Yũt yam } \\
\text { matar cachorro }\end{array}$ & 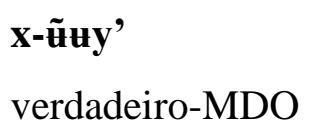 \\
\hline & Mate a onça! & \\
\hline
\end{tabular}




\section{ii) Causativização analítica}

Com relação à causativização com verbos transitivos, todos os verbos testados puderam ser causativizados por dôo 'fazer', que adicionou ao predicado verbal um terceiro argumento agente ou causa. O sujeito da construção transitiva causativizada passa a ser realizado como objeto após esse processo.

A análise acerca desse processo será discutida com mais detalhes no capítulo 5.

\section{iii) Uso dos morfemas xâd e dâr}

A análise preliminar dos predicados transitivos e intransitivos coletados de Martins (2004) mostrou-nos que verbos transitivos são majoritariamente sucedidos por dâr, morfema analisado por Martins (2004) como aspecto pontual (MARTINS, 2004:297); predicados intransitivos, por sua vez, não ocorrem com esse morfema. Estes são sucedidos majoritariamente pelo morfema $x a ̂ d$, analisado por Martins (2004) como morfema de aspecto durativo (MARTINS, 2004:296). Xâd também é analisado pela autora como verbo intransitivo 'passar'. Tendo em vista a relação entre o emprego dos morfemas xâd e dâr e a valência dos predicados verbais, levantamos a seguinte hipótese:

$>\mathrm{O}$ uso de $d \hat{a} r$ e $x a ̂ d$ distingue classes verbais intransitivas e transitivas.

Testamos essa hipótese em trabalho de campo por meio de testes de julgamento de (a)gramaticalidade de sentenças transitivas e intransitivas formadas com ambos os morfemas. É importante salientar que nesse trabalho não testamos as propriedades aspectuais de dâr e $x a ̂ d$, mas testamos seu emprego em relação à valência verbal. Diante disso, não utilizaremos a nomenclatura morfema de aspecto pontual para dâr e morfema de aspecto durativo para $x a ̂ d$, conforme é proposto por Martins (2004). Preferimos o termo morfema de valência (MV) para ambos os morfemas. Dessa forma, não estamos assumindo que esses morfemas codifiquem informações aspectuais, mas que codificam informações de valência. Deixaremos para trabalhos posteriores uma discussão pormenorizada sobre a codificação de aspecto envolvendo essas duas marcas. ${ }^{8}$

\footnotetext{
${ }^{8}$ Há um trabalho de mestrado sendo desenvolvido sobre os aspectos em Dâw pelo aluno Maurício Oliveira Pires de Carvalho. O trabalho é intitulado 'O Aspecto Verbal na Língua Dâw' (trabalho vinculado ao Departamento de Linguística da USP - Programa de Pós-Graduação em Semiótica e Linguística Geral).
} 
Os verbos intransitivos e transitivos testados foram:

\begin{tabular}{c|l|l|l}
\hline Número & \multicolumn{1}{|c|}{ Verbo em Dâw } & \multicolumn{1}{c}{ Tradução } & \multicolumn{1}{c}{ Classe verbal } \\
\hline 1 & ox & Correr & Verbo intransitivo \\
\hline 2 & wiñh & Trabalhar & Verbo intransitivo \\
\hline 3 & rãm xô & Andar & Verbo intransitivo \\
\hline 4 & nõox & Cair & Verbo intransitivo \\
\hline 5 & wutd & Chegar & Verbo intransitivo \\
\hline 6 & woox & Quebrar & Verbo intransitivo \\
\hline 7 & xop & Secar & Verbo intransitivo \\
\hline 8 & weed & Comer & Verbo transitivo \\
\hline 9 & yũt & Matar & Verbo transitivo \\
\hline 10 & kâs & Morder & Verbo transitivo \\
\hline 11 & wâay & Falar & Verbo transitivo \\
\hline 12 & tuk & Querer & Verbo transitivo \\
\hline
\end{tabular}

Tabela 3.19: Verbos intransitivos e transitivos testados com os aspectos xâd e dâr

Procuramos selecionar os verbos acima listados de acordo com as propriedades aspectuais lexicais de dois tipos: propriedade imperfectiva, isto é, que denota uma ação durativa (verbos apresentados nos itens de 1 a 3, para verbos intransitivos; e item 12 verbo transitivo); e propriedade perfectiva, isto é, que denota uma ação pontual (verbos apresentados nos itens de 4 a 11). Essa seleção teve como objetivo verificar se o uso dos morfemas livres $x a ̂ d$ e dâr se deve, além das valências verbais, também às propriedades aspectuais dos verbos selecionados.

Com relação aos verbos intransitivos, a elicitação dos dados mostrou-nos que independentemente da propriedade aspectual do predicado verbal, o uso do morfema $x a ̂ d$ sempre gera sentenças gramaticais com verbos intransitivos; já o uso de dâr sempre forma sentenças agramaticais com verbos intransitivos.

\section{Propriedade Imperfectiva do verbo}

$$
\begin{array}{lcc}
\text { Yam } & \text { 'ox } & \text { xâd } \\
\text { cachorro } & \text { correr } & \text { MV } \\
\text { 'O cachorro correu' }
\end{array}
$$

$\begin{array}{lcc}\text { *Yam } & \text { 'ox } & \text { dâr } \\ \text { cachorro } & \text { correr } & \text { MV }\end{array}$


(79)

$\begin{array}{lll}\text { Dâw } & \text { xut } \quad \text { wĩnh } & \text { xâd } \\ \text { gente } & \text { macho trabalhar } & \text { MV }\end{array}$

'O homem trabalhou'

(80)

$\begin{array}{ll}\text { *Dâw xut wĩnh } & \text { dâr } \\ \text { gente macho trabalhar } & \text { MV }\end{array}$

Propriedade perfectiva do verbo

$(81)$

$\begin{array}{lll}\text { Mâw } & \text { nõox } & \text { xâd } \\ \text { Mamão } \quad \text { cair } & \text { MV } \\ \text { 'O mamão caiu' } & \end{array}$

$(82)$

$\begin{array}{lll}\text { *Mâw } & \text { nõox } & \text { dâr } \\ \text { Mamão } & \text { cair } & \text { MV }\end{array}$

(83)

$\begin{array}{ll}\text { Xop woox } & \text { xâd } \\ \text { copo quebrar } & \text { MV } \\ \text { 'O copo quebrou' } & \\ \end{array}$

$\begin{array}{ll}\text { * Xop woox } & \text { dâr } \\ \text { copo quebrar } & \text { MV }\end{array}$

No entanto, quando esses verbos intransitivos são causativizados, a presença de $x a ̂ d$ passa a formar sentenças agramaticais; e a presença de dâr, por outro lado, passa a formar sentenças gramaticais, independentemente das propriedades aspectuais dos verbos, como podemos ver nos exemplos abaixo9 :

\footnotetext{
${ }^{9}$ A única exceção encontrada nos dados foi a sentença causativa formada com o verbo wutd 'chegar' que teve leitura agramatical tanto na presença de xâd quanto na presença de dâr.

i) *Dâw xut dôo wutd xâd tor-ũuy' gente macho CAUS chegar MV porco-MDO

ii) *Dâw xut dôo wutd dâr tor-ũuy' gente macho CAUS chegar MV porco-MDO
} 
Propriedade Imperfectiva do verbo

$\begin{array}{lllll}\text { *Dâw xut dôo 'ox } & \text { xâd } & \text { yam } \\ \text { gente } & \text { macho CAUS correr } & \text { MV } & \text { cachorro }\end{array}$

(86)

$\begin{array}{cllll}\text { *Dâw ãy dôo wĩnh } & \text { xâd } & \text { dâw } & \text { xut } \\ \text { gente fêmea } & \text { CAUS trabalhar } & \text { MV } & \text { gente } & \text { macho }\end{array}$
Dâw xut dôo 'ox dâr yam
gente macho CAUS correr MV cachorro
'O homem fez o cachorro correr'

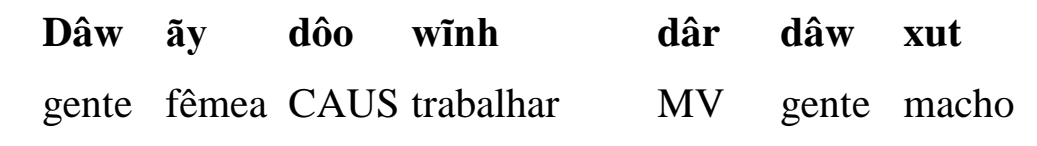

'A mulher fez o homem trabalhar'

Propriedade perfectiva do verbo

$\begin{array}{clll}\text { *Dâw xut dôo nõox } & \text { xâd } & \text { mâw } \\ \text { gente macho CAUS cair } & \text { MV } & \text { mamão }\end{array}$

Dâw xut dôo nõox dâr mâw
gente macho CAUS cair MV mamão
'O homem fez o mamão cair'

$\begin{array}{llll}\text { *Dâw xut dôo woox } & \text { xâd } & \text { xop } \\ \text { gente } & \text { macho CAUS quebrar } & \text { MV } & \text { copo }\end{array}$

$\begin{array}{lllll}\text { Dâw } & \text { xut dôo woox } & \text { dâr } & \text { xop } \\ \text { gente } & \text { macho CAUS quebrar } & \text { MV } & \text { copo }\end{array}$

'O homem fez o copo quebrar'

Com relação aos verbos transitivos, observamos que sentenças cujo verbo possui propriedades perfectivas são agramaticais diante do uso de $x a ̂ d$ e gramaticais diante do uso de dâr. $\mathrm{O}$ único verbo transitivo testado nessa pesquisa de propriedade imperfectiva (t $u k$ 'querer') formou sentenças agramaticais com as duas marcas supracitadas. 
Propriedade imperfectiva do verbo

(93) *Dâw ãy tuk xâd baa'
gente fêmea querer MV beiju

(94) *Dâw ãy tuk dâr baa' gente fêmea querer MV beiju

Propriedade perfectiva do verbo

(95)

(96)

$\begin{array}{llll}* \text { Yam } & \text { yũt } & \text { xâd } & \text { nũ } \\ \text { cachorro } & \text { matar } & \text { MV } & \text { rato }\end{array}$

$\begin{array}{llll}\text { Yam } & \text { yũt } \quad \text { dâr } & \text { nũ } \\ \text { cachorro } & \text { matar } & \text { MV } & \text { rato } \\ \text { 'O cachorro matou o rato' } & \end{array}$

*Yam kâs $\quad$ xâd buuy-ũuy'

Cachorro morder MV homem branco-MDO

$\begin{array}{llll}\text { Yam } & \text { kâs } & \text { dâr } & \text { buuy-ũuy' } \\ \text { cachorro } & \text { morder } & \text { MV } & \text { homem branco-MDO }\end{array}$

'O cachorro mordeu o homem branco'

É necessário verificar outros verbos transitivos com propriedades imperfectivas para ter um resultado mais claro quanto à propriedade do uso de xâd e dâr nesses ambientes, ou seja, se a agramaticalidade gerada é uma propriedade do verbo ou da classe verbal.

Sentenças transitivas com xâd podem ser gramaticais, caso ele esteja sendo usado como verbo 'passar'.

(99)
Yam yũt xâd nũ
cachorro matar passar rato
'O cachorro passou matando o rato' 
$(100)$
Yam
kâs
xâd
buuy-ũuy'
Cachorro
morder
passar
homem branco-MDO
'O cachorro passou mordendo o homem branco'

Assim, percebemos que o uso dos morfemas livres dâr e xâd está relacionado às valências verbais dos verbos em Dâw, o que corrobora nossa hipótese inicial de que o uso dos morfemas supracitados distingue classes verbais intransitivas e transitivas. Assim, dâr é empregado com predicados verbais transitivos e xâd é empregado com predicados verbais intransitivos.

\subsubsection{Classe dos verbos bitransitivos}

Submetemos os verbos de valência bitransitiva a três testes:

i. Reconhecimento de predicados bitransitivos;

ii. Produção de predicados bitransitivos

iii. Apagamento de constituintes;

Segundo Martins (2004), há em Dâw cinco verbos bitransitivos:

\begin{tabular}{c|c|c}
\hline Número & Verbos em Dâw & Tradução \\
\hline 1 & nõo & Dar \\
\hline 2 & buy & Jogar \\
\hline 3 & yõor & Passar remédio \\
\hline 4 & yug & Fazer vinho \\
\hline 5 & w'oob & Pôr em cima \\
\hline \multicolumn{2}{c}{ Tabela 3.20: Verbos bitransitivos testados } \\
\hline
\end{tabular}

Submetemos esses verbos a dois tipos de testes: reconhecimento de predicados bitransitivos e produção de predicados bitransitivos.

Os resultados dos testes mostraram-nos que os falantes da língua reconhecem apenas o verbo nõo 'dar' como verbo bitransitivo. Os outros verbos identificados por Martins (2004) são reconhecidos pelos falantes como:

i) Predicados transitivos com traduções diferentes das apresentadas por pela autora: buy 'derrubar' (exemplo 101);

ii) Sintagmas nominais: yõor 'remédio' (exemplo 102), yug 'vinho'(exemplo 103);

iii) Posposições: wôob 'em cima de' (exemplo 104). 
(101) Mũnh

$\begin{array}{llll}\text { buy } & \text { dâr } & \text { ray } & \text { nồ }^{\mathbf{1 0}} \\ \text { derrubar } & \text { MV } & \text { sorva } & \text { maduro }\end{array}$

1PS.OBL derrubar MV sorva maduro

'Derrube para mim sorva ${ }^{11}$ madura!"

(102) Ãr dak dâw tee rẽd yõor

1PS colocargente filho em remédio

'Eu coloquei remédio na criança'

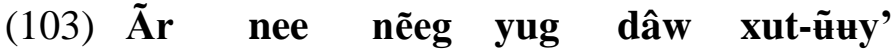

1PS fazer mel vinho gente macho-MDO

'Eu fiz vinho de mel para o homem'

(104) Tir rõk wôob dâr mân baak mũux

3PS cortar em cima de MV inajá cacho curupira

wâ, 12

em cima

'Ele cortou em cima do curupira cacho de inajá'

Dessa forma, o único verbo que realmente predica três argumentos em Dâw, e que até o momento foi reconhecido no trabalho de campo elaborado por nós, é o verbo nõo 'dar'.

Com relação ao verbo nõo 'dar', a sua ordem defaut é S V OD OI. Não foram identificados morfemas de concordância e modo verbal nos paradigmas verbais testados, do mesmo modo como vimos com as construções intransitivas e transitivas.

(105) Woor nõo weed dâw xut-ũuy'

tukano dar comida gente macho-MDO

'O tukano deu comida para o homem'

Submetemos o verbo nõo 'dar' ao teste de apagamento de constituintes. $\mathrm{Na}$ próxima seção, apresentamos os resultados desse teste.

\footnotetext{
${ }^{10}$ Sentença retirada de Martins (2004) e traduzida pelo informante.

${ }^{11}$ Fruto da sorveira (Dicionário Houaiss).

${ }^{12}$ Sentença retirada de Martins (2004) e traduzida pelo informante.
} 


\section{Resultado do teste}

i) Apagamento de constituintes

Com relação ao apagamento dos argumentos do verbo (sujeito, objeto direto ou objeto indireto), observamos, pelos dados elicitados, que é possível apagar o sujeito, gerando uma leitura de sentença imperativa, de modo semelhante ao visto com sentenças transitivas (exemplo 106). Também é possível apagar objetos diretos (exemplo 107), todavia não é possível apagar objetos indiretos (exemplo 108).

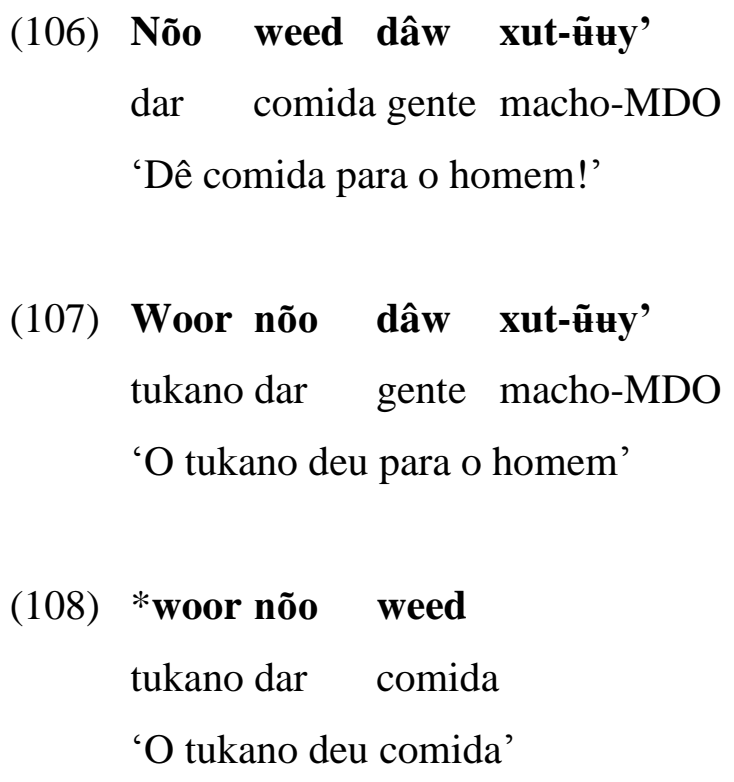

\subsection{Síntese do capítulo}

Nesse capítulo, apresentamos a proposta de reclassificação das classes verbais da língua Dâw. Martins (2004) classifica os verbos em Dâw em nove classes verbais, a saber: verbo ativo intransitivo, verbo ativo transitivo, verbo ativo bitransitivo, verbo de processo, verbo estativo equativo identificacional, verbo estativo equativo existencial, verbo estativo descritivo atributivo, verbo estativo descritivo qualificativo e verbo estativo descritivo posicional. Por meio de testes linguísticos variados, incluindo alternância de valência e julgamento de (a)gramaticalidade, mostramos que é possível simplificar essa classificação de Martins (2004) e reagrupar esses verbos em três classes verbais de acordo com a valência do verbo: classe dos verbos intransitivos (verbo ativo intransitivo, verbo de processo, verbo estativo equativo identificacional, verbo estativo equativo existencial, verbo estativo descritivo atributivo, verbo estativo descritivo 
qualificativo e verbo estativo descritivo posicional); classe dos verbos transitivos (verbo ativo transitivo); e classe dos verbos bitransitivos (verbo nõo 'dar').

Cada classe verbal apresentada mostrou padrões sintáticos e morfológicos específicos que nos possibilitou realizar essa reclassificação. De modo geral, os verbos intransitivo, de processo, estativo equativo (e suas subclasses) e estativo descritivo (e suas subclasses), analisados nesse trabalho como verbos intransitivos, não podem ser predicados de sentenças reflexivas e não ocorrem com o morfema dâr, mas ocorrem com xâd. Ainda dentro dessa classe, é possível identificar subclasse de verbos alternantes - isto é, que alternam livremente entre uma forma incoativa e causativa - e verbos não-alternantes. Além disso, identificamos que os predicados analisados por Martins (2004) como verbos estativos descritivos são adjetivos na língua. A verbalização do sintagma adjetival ocorre por meio de uma cópula ( $r a \tilde{m}$ 'ir') que toma como complemento o adjetivo. Todos os verbos podem ser causativizados por dôo 'fazer'.

Os verbos transitivos (ativos transitivos na classificação de Martins, 2004) podem formar sentenças reflexivas, ocorrem com o morfema dâr, mas não ocorrem com $x a ̂ d$. Eles podem ser causativizados por dôo 'fazer'. Apenas o argumento objeto pode ser removido da sentença sem gerar agramaticalidade. A remoção do sujeito ocorre somente se o modo da sentença for imperativo.

O único verbo bitransitivo em Dâw encontrado nesse trabalho foi o verbo nõo 'dar', que ocorre com mais de dois argumentos na sentença; o seu objeto direto pode ser removido, mas não seu objeto indireto. Sujeitos só podem ser removidos se configurarem sentenças imperativas. Esse verbo não pode ser causativizado por dôo. Os outros verbos bitransitivos apresentados em Martins (2004) não foram identificados e nem produzidos pelos falantes testados. 


\section{Capítulo 4: 0 sistema tonal da língua Dâw}

\subsection{Introdução}

Neste capítulo, discutimos o sistema tonal da língua Dâw. A abordagem desse tópico é importante nesta dissertação uma vez que as abordagens anteriores (Martins, 2004; Martins, 2005), acerca dos processos de mudança de valência em Dâw, afirmam que há, na língua em estudo, morfemas tonais responsáveis pelo aumento e diminuição de valência dos verbos.

Durante nossa pesquisa, em um primeiro momento, analisamos o processo de transitivização e o sistema tonal de sentenças intransitivas e transitivizadas. Testamos 24 verbos intransitivos em dois tipos sentencias: a sentença intransitiva ou incoativa, e a sentença transitiva ou causativa com a manipulação de contextos tonais específicos. A análise dos dados coletados mostrou-nos que o sistema tonal em Dâw é previsível na sentença. Assim, em nível prosódico, os itens lexicais que compõem as sentenças são divididos em frases fonológicas com núcleo à direita. Estas são formadas por no mínimo duas e no máximo três silabas, às quais são associadas previsivelmente melodias tonais $(\mathrm{L}$ ' $\mathrm{H})$ e $(\mathrm{L} \mathrm{L}$ ' $\mathrm{H})$.

Diante dessas descobertas, vimos como necessária a reavaliação dos processos gramaticais como a transitivização e intransitivização que, a nosso ver, não condicionam mudanças tonais dos verbos, mas decorrem de um padrão tonal previsível.

Na seção 4.1, apresentamos uma breve discussão acerca da análise de Martins (2004) sobre o sistema tonal da língua Dâw; na seção 4.2, apresentamos uma discussão acerca dos processos de transitivização por meio de morfema tonal descendente; na seção 4.3, apresentamos uma discussão sobre os processos de intransitivização por apagamento tonal do verbo; na seção 4.4, apresentamos a análise original de Storto, Costa e Andrade (manuscrito) sobre o sistema tonal dos itens lexicais em nível sentencial e a repercussão dessa análise para o entendimento dos processos de transitivização e intransitivização. Por fim, na seção 4.5, fazemos uma síntese do que foi discutido ao longo do capítulo. 


\subsection{0 sistema tonal da língua Dâw segundo Martins (2004)}

Segundo Martins (2004), na língua Dâw, observa-se a ocorrência de dois tons distintos: o descendente $(\widehat{\mathrm{HL}})$, e o ascendente $(\widehat{\mathrm{LH}})$, ambos tons de contorno. O emprego desses tons pode distinguir o significado de palavras cujos segmentos fonológicos são idênticos, o que caracterizaria essa língua como tonal. Observemos, por exemplo, três pares mínimos apresentados por Martins (2004). Segundo a autora, o único traço que diferencia essas palavras são os tons. Assim, em (1a) não há tom (tom zero), em (1b) há a ocorrência de tom descendente $(\widehat{\mathrm{HL}})$ e $(1 \mathrm{c})$, de tom ascendente $(\widehat{\mathrm{LH}})$.

$$
\begin{array}{ll}
\text { a) } & {[\text { mãj }] \text { - pagamento }} \\
\text { b) } & {[\text { mã̀j }]-\text { buraco }} \\
\text { c) } & {[\text { mã́j }]-\text { muito }}
\end{array}
$$

(MARTINS, 2004:79)

Para Martins (2004), a realização de tons ascendente e descendente implica o alongamento da vogal na qual o tom recai. Todavia, após análise dos dados coletados em trabalho de campo, ainda não está claro para nós se, de fato, é o tom que prolonga a vogal, ou se é o prolongamento que condiciona a percepção de pitch elevado da sílaba.

Segundo a autora, as variações tonais nos lexemas estão condicionadas por algumas restrições fonotáticas da língua, como padrão silábico e sonoridade da coda da sílaba. Por exemplo, o tom descendente ocorreria obrigatoriamente em monossílabos CV e na maioria dos monossílabos CVC com coda sonora. Segundo Martins (2004), em $70 \%$ dos monossílabos CVC com coda sonora em que o tom está presente, é observada a ocorrência de tom descendente, sendo que os 30\% restantes têm padrão tonal ascendente. Tons descendentes nunca ocorreriam com monossílabos CVC com coda surda, os quais, por sua vez, só ocorrem com tom ascendente. Sufixos que têm o padrão silábico - VC podem ocorrer tanto com tom descendente quanto ascendente ou atonal. $\mathrm{O}$ tom zero, ou a ausência de tom, segundo a autora, pode ocorrer com todos os tipos de sílabas, isto é: CVC, CV e -VC. No entanto, quando uma palavra CV é atonal, ocorre previsivelmente a epêntese de uma fricativa glotal.

De acordo com Martins (2004), uma palavra pode apresentar um ou mais de um tom, de acordo com a sua estrutura silábica. Palavras dissilábicas (estrutura pouco comum em Dâw) teriam dois tons, um para cada sílaba da palavra, enquanto palavras monossilábicas apresentariam um único tom pronunciado no núcleo da sílaba, isto é, a 
vogal. A autora afirma que a sílaba que comporta o tom também é acentuada e sempre ocupa a última posição da palavra.

Segundo Martins (2004), diferentemente de palavras dissilábicas, as palavras compostas por mais de um lexema apresentam um único tom em toda a composição. De acordo com a autora, o acento e o tom recaem na última sílaba da palavra composta e o item lexical da composição que ocupa a posição tônica obedece a um dos dois padrões seguintes: se for uma palavra atonal em isolamento, adquire tom (a realização de ascendente ou descendente vai depender da sonoridade da coda); se for uma palavra tonal (ascendente ou descendente), preservará seu tom. Por outro lado, o item lexical da composição que ocupa a posição átona perde seu tom lexical ${ }^{1}$.

Desse modo, uma palavra composta como [mPẼh-háh] 'sereno' é formada pela junção de duas palavras: [mč́h] 'estrela' e [háh] 'saliva'. Cada uma dessas palavras possui tom ascendente em isolamento. Todavia, ao se comporem para formar uma única

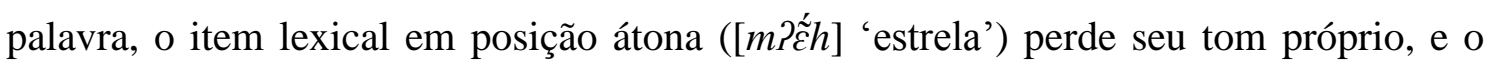
item lexical em posição tônica (háh 'saliva') preserva seu tom.

Segundo Martins (2004), o tom em Dâw, além de ter funções lexicais, também funcionaria como um morfema na língua, sendo empregado em contextos gramaticais específicos, como transitivização (morfema tonal descendente), intransitivização (tom zero), entre outras funções. No entanto, a análise de dados originais coletados em trabalho de campo acerca dos processos de transitivização e intransitivização mostrounos que a ocorrência de tom descendente ou zero está condicionada por padrões tonais específicos das sílabas das palavras que compõem frases e sintagmas.

\subsection{0 processo de transitivização segundo Martins (2004)}

Segundo Martins (2004), o processo de transitivização estaria relacionado às mudanças tonais do verbo, ou seja, verbos intransitivos podem ser transitivizados por meio do tom descendente $(\widehat{\mathrm{HL}})^{2}$, que integrado aos verbos CVC com coda desvozeada,

\footnotetext{
${ }^{1}$ Os lexemas tonais que dão origem à palavra composta, quando ocupam a posição átona na palavra, por regra, perdem seus tons lexicais, enquanto os que ocupam a posição de sílaba tônica, geralmente têm seus tons preservados. Ainda, morfemas atonais, quando ocupam a posição de sílaba tônica na palavra composta, podem adquirir tom (...) (MARTINS, 2004: 89).

${ }^{2}$ Lembramos o leitor que, na ortografia Dâw, o tom é marcado pela duplicação da vogal na qual ele é pronunciado. Veja mais detalhes na seção 1.1 .3 do capítulo 1.
} 
realiza-se como ascendente, pois palavras com coda surda não podem ter tom descendente (só ascendente ou neutro).

Exemplo:
a)
tir sâ'-baax yêt xa
2SG paneiro estar no chão estar agachado
'O paneiro dele está jogado no chão'
b) tir yêet dâr tir sâ'-baax
3SG estar no chão:TRANV PONT 3SG paneiro

'Ele pôs o paneiro deitado no chão'

(MARTINS, 2004: 232)

Segundo Martins (2004), no exemplo apresentado em (2a), o verbo estativo yêt 'estar no chão' projeta apenas um argumento, o DP tir sâ'-baax 'paneiro dele'. Em (2b), com o acréscimo do morfema tonal transitivizador, o predicado transitivizado yêet 'estar no chão' passaria a projetar, além do DP objeto tir sâ'-baax 'paneiro dele', um argumento agente, o sujeito pronominal tir 'ele'.

Exemplo:
a) çutw
tâag tũm'
pupunha caule ser reto e cilíndrico
'O caule da pupunha é reto e cilíndrico'
b) Dâw-‘ãay tũum tir yuun
gente-fêmea ser reto e cilíndrico:TRANV 3SG roupa
'A mulher faz o pano dela ser reto e cilíndrico'
('A mulher costura a roupa dela')

(MARTINS, 2004: 229)

De acordo com Martins (2004), no exemplo apresentado em (3a), o verbo intransitivo tüm' 'ser reto e cilíndrico' possui apenas um argumento: çttuw tâag 'caule da pupunha'. Após a sua transitivização via morfema tonal, em (3b), o verbo transitivizador tũtum 'ser reto e cilíndrico' passa a projetar dois argumentos: um sujeito agente $d \hat{a} w$ - 'ãay 'mulher' e o DP objeto tir yuun 'roupa dela'. 


\subsection{0 processo de intransitivização segundo Martins (2004)}

No que se refere à intransitivização, Martins (2004) afirma que esse processo também ocorre por meio de mudança tonal. Verbos transitivos passam por intransitivização por meio do apagamento do seu tom lexical. Segundo a autora: "o processo de intransitivação consiste no apagamento do tom lexical de verbos transitivos ativos, decresce o grau de dinamicidade desses verbos e aproxima-os dos verbos de processo" (MARTINS, 2004: 234).

Exemplo:

(4)

$\begin{array}{llll}\text { a) ‘ãr ceep } & \text { doo' } & \text { yum } \\ & 1 \mathrm{SG} \quad \text { arrebentar } \mathrm{Mov}^{3} & \text { cipó } \\ & \text { 'Eu arrebentei o cipó' } & \\ & & \\ \text { b) } & \text { Yum cep } & \text { xâd } \\ & \text { cipó } \quad \text { arrebentar:INTRV } & \text { DUR } \\ & \text { 'O cipó arrebentou' } & \end{array}$

(MARTINS, 2004:674)

No exemplo (4a), vemos o verbo transitivo ceep 'arrebentar' em uma sentença assertiva de ordem SVO. Em (4b), observamos a ocorrência do mesmo verbo em uma construção intransitiva, na qual, a partir do apagamento do morfema descendente tonal (cep), o verbo tem seu número de argumentos reduzido, fazendo com que o verbo transitivo passe a intransitivo. A versão intransitiva desse verbo possui apenas um argumento, a saber, yun 'cipó'; diferentemente da versão transitiva do verbo que possui dois argumentos, 'ãr 'eu' e yun 'cipó'.

O mesmo processo de apagamento tonal, segundo a autora, pode formar orações médias em Dâw, nas quais o sujeito e o objeto são correferenciais. Nessas construções, o evento verbal ocorre sem a intervenção de um sujeito agente, pois tal evento se dá de modo natural, sem intervenção exterior.

Exemplo:
a)
$\begin{array}{ll}\text { ‘ãr } & \text { lood } \\ 1 \mathrm{SG} & \text { descascar }\end{array}$
dâr mũunh

'Eu me descasquei'

\footnotetext{
${ }^{3}$ Verbo movimentar (glosa de Martins 2004).
} 
$\begin{array}{lllll}\text { b) ‘ãr } & \text { lod } & \text { rãm } & \text { yu' } & \text { xad } \\ \text { 1SG } & \text { descascar:INTRV } & \text { ir } & \text { estar quente } & \text { por causa de }\end{array}$

'Eu descasquei por causa do sol'

(MARTINS, 2004:674)

\subsection{0 sistema tonal da língua Dâw (STORTO, COSTA E ANDRADE, em elaboração)}

No trabalho de campo realizado no mês de julho de 2013, testamos o padrão tonal de palavras em isolamento (conforme descrito por Martins, 2004) em três tipos de construções: sentenças intransitivas, transitivizadas ${ }^{4}$ e causativizadas ${ }^{5}$. Foram testados 25 verbos intransitivos, nesses três tipos de construções. No total, elicitamos 350 sentenças declarativas, cada uma das quais foi gravada três vezes.

$\mathrm{Na}$ tabela abaixo, apresentamos os verbos intransitivos testados:

\begin{tabular}{l|l|l|l}
\hline Número & \multicolumn{1}{|c|}{ Verbo } & \multicolumn{1}{c}{ Tradução } & \multicolumn{1}{c}{$\begin{array}{c}\text { Tom segundo } \\
\text { Martins (2004) }\end{array}$} \\
\hline 1 & wutd & Chegar & Descendente \\
\hline 2 & baad & Virar & Descendente \\
\hline 3 & 'eed & Virar & Descendente \\
\hline 4 & bâr & Derramar & Atonal \\
\hline 5 & pêt & Quebrar & Atonal \\
\hline 6 & xop & Secar & Atonal \\
\hline 7 & pô & Abrir & Atonal \\
\hline 8 & baax & Aparecer & Ascendente \\
\hline 9 & kũm & Afundar & Atonal \\
\hline 10 & 'ox & Correr & Atonal \\
\hline 11 & rôd & Sair & Atonal \\
\hline 12 & 'ãa & Dormir & Atonal \\
\hline 13 & suuk & Caçar & Ascendente \\
\hline 14 & yelêew & Transformar-se & Ascendente \\
\hline 15 & kog'õogn & Desmaiar & Ascendente \\
\hline 16 & pôw' & Boiar & Atonal \\
\hline 17 & pêg-saak & Crescer & Atonal-Ascendente \\
\hline 18 & bâay & Arrotar & Descendente \\
\hline 19 & çeeb & Mudar(-se) & Descendente \\
\hline 20 & 'ub & Acordar & Atonal \\
\hline
\end{tabular}

\footnotetext{
${ }^{4}$ Transitivização é um processo de formação de verbos transitivos a partir de uma raiz verbal intransitiva, de uma raiz não verbal ou acategorial.

5 A causativização é um processo no qual é adicionado ao predicado verbal um argumento agente ou causa, por meio da inserção de um auxiliar causativo, aumentando a valência do verbo.
} 


\begin{tabular}{l|l|l|l}
\hline 21 & beg & Clarear & Atonal \\
\hline 22 & rõ & Queimar & Atonal \\
\hline 23 & çom & Banhar(-se) & Atonal \\
\hline 24 & wĩnh & Trabalhar & Atonal \\
\hline 25 & nõx & Cair & Atonal \\
\hline
\end{tabular}

Tabela 4.0: Verbos intransitivos testados

A metodologia utilizada em nossa pesquisa foi a elicitação de sentenças intransitivas e transitivizadas em Dâw com a manipulação de contextos tonais específicos. Embasamo-nos na tonologia dos elementos como descrito em Martins (2004) e Martins (2005) para compor as sentenças elicitadas ${ }^{6}$. Observamos o comportamento do padrão tonal de itens lexicais a partir da produção de sentenças em Dâw, baseadas na tradução de sentenças em português. Os itens lexicais que compuseram as sentenças foram escolhidos previamente de acordo com os seus tons em isolamento.

\section{i) Elicitação de sentenças intransitivas}

As sentenças intransitivas em Dâw são formadas por sujeito + verbo.

Exemplo:

a) Sujeito + Verbo

(6) Bee pêt

pau quebrar

'O pau quebrou'

O protocolo de elicitação das sentenças intransitivas foi composto por três contextos tonais, de acordo com o tom do verbo da sentença: atonal, ascendente e descendente. Em cada contexto formado, montamos ambientes nos quais o sujeito (atonal, descendente ou ascendente) pudesse se compor com os verbos atonais, de tom ascendente e descendente.

Apresentamos, a seguir, o protocolo de elicitação das sentenças intransitivas:

\footnotetext{
${ }^{6}$ Com relação à tonologia dos elementos escolhidos, observamos com a elicitação dos dados que dois dos verbos atonais escolhidos para compor os testes, a saber, ' $\tilde{a}$ 'dormir' e bâr 'derramar', possuem tom ascendente em isolamento. Desse modo, discordamos das análises de Martins (2004) e Martins (2005) que afirmam que esses verbos são atonais. Em nosso trabalho, analisamos o verbo 'dormir' e 'derramar', em Dâw, como um verbo cujo tom é ascendente e passamos a registrá-lo com a seguinte ortografia: 'ãa $e$ bâar, o que mostra que essas palavras são tonais (palavras tonais são registradas com o duplicamento da vogal sob a qual o tom recai).
} 


\begin{tabular}{l|l|l}
\hline \multicolumn{1}{c}{$\begin{array}{c}\text { Contexto tonal } \\
\text { Atonal }\end{array}$} & \multicolumn{1}{c}{$\begin{array}{c}\text { Contexto tonal } \\
\text { Ascendente }\end{array}$} & \multicolumn{1}{c}{$\begin{array}{c}\text { Contexto tonal } \\
\text { Descendente }\end{array}$} \\
\hline S atonal $+\mathrm{V}$ atonal & S atonal + V ascendente & S atonal + V descendente \\
\hline S ascendente $+\mathrm{V}$ atonal & $\begin{array}{l}\text { S ascendente }+\mathrm{V} \\
\text { ascendente }\end{array}$ & $\begin{array}{l}\text { S descendente }+\mathrm{V} \\
\text { descendente }\end{array}$ \\
\hline S descendente $+\mathrm{V}$ atonal & $\begin{array}{l}\text { S descendente }+\mathrm{V} \\
\text { ascendente }\end{array}$ & $\begin{array}{l}\text { S ascendente }+\mathrm{V} \\
\text { descendente }\end{array}$ \\
\hline
\end{tabular}

Tabela 4.1: Protocolo de elicitação de sentenças intransitivas

\section{ii) Elicitação de sentenças transitivizadas}

As sentenças transitivizadas em Dâw são formadas por sujeito (NP) + verbo (V) + objeto (NP).

Exemplo:

b) Sujeito + Verbo + Objeto

$\begin{array}{lll}\text { Tir } & \text { pêt } & \text { bee-ũuy' } \\ \text { 3PS } & \text { quebrar } & \text { pau-MDO }\end{array}$

'Ele quebrou o pau'

Já as sentenças causativizadas possuem a seguinte forma: sujeito (NP) + CAUS (dô) + verbo (V) + objeto (NP)

Exemplo:

c) Sujeito + causativizador + verbo + objeto

$\begin{array}{llll}\text { Tir } & \text { dô } & \text { pêt } & \text { bee- } \mathbf{u} y \\ \text { 3PS } & \text { CAUS } & \text { quebrar } & \text { pau-MDO }\end{array}$

'Ele quebrou o pau/Ele fez o pau quebrar'

O protocolo de elicitação das sentenças transitivas e causativizadas foi composto por três contextos tonais, baseados no tom do verbo da sentença: atonal, ascendente e descendente. Em cada contexto formado, compusemos ambientes nos quais tanto o sujeito (atonal, descendente ou ascendente) quanto o objeto (atonal, descendente ou ascendente) pudessem se compor com verbos atonais, de tom ascendente e descendente. Foram testadas todas as possibilidades de composição tonal entre os três elementos da sentença, isto é: sujeito, verbo e objeto.

Apresentamos, a seguir, o protocolo de elicitação das sentenças transitivizadas e causativizadas: 


\begin{tabular}{|c|c|c|}
\hline \multicolumn{3}{|c|}{ Nome + Verbo transitivizado e causativizado } \\
\hline $\begin{array}{c}\text { Contexto tonal } \\
\text { Atonal }\end{array}$ & $\begin{array}{c}\text { Contexto tonal } \\
\text { Ascendente }\end{array}$ & $\begin{array}{c}\text { Contexto tonal } \\
\text { Descendente }\end{array}$ \\
\hline $\begin{array}{l}\mathrm{S} \text { atonal }+(\mathrm{dôo})+\mathrm{V} \\
\text { atonal+ } \mathrm{O} \text { atonal }\end{array}$ & $\begin{array}{l}\mathrm{S} \text { atonal }+(\text { dôo })+\mathrm{V} \\
\text { ascendente }+\mathrm{O} \text { atonal }\end{array}$ & $\begin{array}{l}\mathrm{S} \text { atonal }+(\text { dôo })+\mathrm{V} \\
\text { descendente }+\mathrm{O} \text { atonal }\end{array}$ \\
\hline $\begin{array}{l}\text { S atonal+ }(\text { dôo })+V \text { atonal } \\
+0 \text { ascendente }\end{array}$ & $\begin{array}{l}\mathrm{S} \text { atonal+ }(\mathrm{dôo})+\mathrm{V} \\
\text { ascendente }+\mathrm{O} \text { ascendente }\end{array}$ & $\begin{array}{l}\mathrm{S} \text { atonal }+(\text { dôo })+\mathrm{V} \\
\text { descendente }+0 \\
\text { ascendente }\end{array}$ \\
\hline $\begin{array}{l}\mathrm{S} \text { atonal }+(\text { dôo })+\mathrm{V} \\
\text { atonal }+\mathrm{O} \text { descendente }\end{array}$ & $\begin{array}{l}\mathrm{S} \text { atonal }+(\text { dôo })+\mathrm{V} \\
\text { ascendente }+0 \text { descendente }\end{array}$ & $\begin{array}{l}\mathrm{S} \text { atonal }+(\text { dôo })+V \\
\text { descendente }+\mathrm{O} \\
\text { descendente }\end{array}$ \\
\hline $\begin{array}{l}\mathrm{S} \text { ascendente }+(\mathrm{dôo})+\mathrm{V} \\
\text { atonal }+\mathrm{O} \text { atonal }\end{array}$ & $\begin{array}{l}\mathrm{S} \text { ascendente }+(\text { dôo })+\mathrm{V} \\
\text { ascendente }+0 \text { atonal }\end{array}$ & $\begin{array}{l}\mathrm{S} \text { ascendente }+(\text { dôo })+\mathrm{V} \\
\text { descendente }+0 \text { atonal }\end{array}$ \\
\hline $\begin{array}{l}\mathrm{S} \text { ascendente }+(\text { dôo })+\mathrm{V} \\
\text { atonal }+\mathrm{O} \text { ascendente }\end{array}$ & $\begin{array}{l}\mathrm{S} \text { ascendente }+(\text { dôo })+\mathrm{V} \\
\text { ascendente }+\mathrm{O} \text { ascendente }\end{array}$ & $\begin{array}{l}\text { S ascendente }+(\text { dôo })+V \\
\text { descendente }+0 \\
\text { ascendente }\end{array}$ \\
\hline $\begin{array}{l}\mathrm{S} \text { ascendente }+(\text { dôo })+\mathrm{V} \\
\text { atonal }+0 \text { descendente }\end{array}$ & $\begin{array}{l}\mathrm{S} \text { ascendente }+(\text { dôo })+V \\
\text { ascendente }+0 \text { descendente }\end{array}$ & $\begin{array}{l}\text { S ascendente }+(\text { dôo })+V \\
\text { descendente }+0 \\
\text { descendente }\end{array}$ \\
\hline $\begin{array}{l}\mathrm{S} \text { descendente }+(\mathrm{dôo})+\mathrm{V} \\
\text { atonal }+\mathrm{O} \text { atonal }\end{array}$ & $\begin{array}{l}\mathrm{S} \text { descendente }+(\text { dôo })+\mathrm{V} \\
\text { ascendente }+0 \text { atonal }\end{array}$ & $\begin{array}{l}\mathrm{S} \text { descendente }+(\text { dôo })+\mathrm{V} \\
\text { descendente }+\mathrm{O} \text { atonal }\end{array}$ \\
\hline $\begin{array}{l}\mathrm{S} \text { descendente }+(\text { dôo })+\mathrm{V} \\
\text { atonal }+\mathrm{O} \text { ascendente }\end{array}$ & $\begin{array}{l}\mathrm{S} \text { descendente }+(\text { dôo })+V \\
\text { ascendente }+O \text { ascendente }\end{array}$ & $\begin{array}{l}\mathrm{S} \text { descendente }+(\text { dôo })+\mathrm{V} \\
\text { descendente }+\mathrm{O} \\
\text { ascendente }\end{array}$ \\
\hline $\begin{array}{l}\mathrm{S} \text { descendente }+(\text { dôo })+\mathrm{V} \\
\text { atonal }+\mathrm{O} \text { descendente }\end{array}$ & $\begin{array}{l}\mathrm{S} \text { descendente }+(\text { dôo })+\mathrm{V} \\
\text { ascendente }+0 \text { descendente }\end{array}$ & $\begin{array}{l}\text { S descendente }+(\text { dôo })+V \\
\text { descendente }+0 \\
\text { descendente }\end{array}$ \\
\hline
\end{tabular}

Tabela 4.2. Protocolo de elicitação de sentenças transitivizadas e causativizadas

A análise original dos dados apresentada nesta dissertação está presente em Storto, Costa e Andrade (em elaboração). Nesse trabalho, percebemos que em nível sentencial, a língua Dâw não apresenta apenas tons de contorno, conforme analisa Martins (2004), mas também encontramos ocorrências de tom alto (H) e baixo (L).

As sílabas das palavras que formam as sentenças são organizadas em frases fonológicas (um nível da hierarquia prosódica, Nespor \& Vogel 1986). Essas frases são formadas por duas ou três sílabas às quais se associam tons previsíveis presentes nos três tipos de sentenças estudadas: intransitivas, transitivizadas e causativizadas.

As frases fonológicas têm seus núcleos à direita e a sílaba (unidade da frase fonológica) carrega um tom que pode ser baixo $(\mathrm{L})$, alto $(\mathrm{H})$, ou de contorno - $(\widehat{\mathrm{LH}})$ ou $(\widehat{\mathrm{HL}})$. A última sílaba da frase fonológica, que também é a sílaba acentuada (o núcleo da frase fonológica), é pronunciada com tom alto $(\mathrm{H})$ (ou com tom de contorno ( $\widehat{\mathrm{HL}})$ se for 
uma sílaba tonal no léxico). As outras sílabas da frase são pronunciadas com tom baixo (L). Como os itens lexicais em Dâw são majoritariamente monossilábicos, frequentemente cada item lexical em Dâw recebe um único tom. O padrão ( $\widehat{\mathrm{LH}})$ só é encontrado no início de um enunciado, atrelado a uma palavra fonológica não fraseada.

A seguir, apresentamos um quadro síntese dos padrões tonais encontrados em todos os ambientes estudados (intransitivas, transitivizadas e causativizadas por $d \hat{o} o$ )

\begin{tabular}{|c|c|c|}
\hline & Padrão tonal & Exemplos \\
\hline \multirow[t]{4}{*}{$\begin{array}{l}2 \text { sílabas/ } \\
\text { tons por } \\
\text { sentença }\end{array}$} & $\left(\mathrm{L}^{\prime} \mathrm{H}\right)$ & $\begin{array}{l}\text { Tir 'ox } \\
\text { (L H) } \\
\text { Ele correu }\end{array}$ \\
\hline & (L'HL) & $\begin{array}{l}\text { Tir 'ãa } \\
\text { (L } \widehat{\text { HLL) }} \\
\text { Ele dormiu }\end{array}$ \\
\hline & $\left(\widehat{\mathrm{LH}} \mathrm{H}^{\prime} \mathrm{H}\right)$ & $\begin{array}{l}\text { Buuy rôd } \\
(\hat{\mathbf{L} H} \quad \mathbf{H}) \\
\text { O homem branco saiu } \\
\end{array}$ \\
\hline & ( $\widehat{\mathrm{L} H}$ ' $\widehat{\mathrm{HL}})$ & 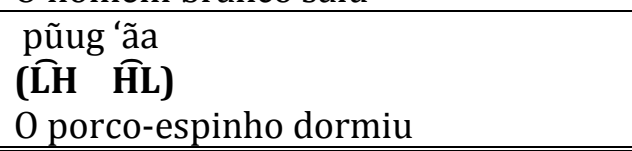 \\
\hline \multirow[t]{4}{*}{$\begin{array}{l}\text { sílabas/ } \\
\text { tons por } \\
\text { sentença }\end{array}$} & (L L'H) & $\begin{array}{l}\text { Tir kog'õogn } \\
(\mathbf{L} \quad \mathbf{L} \quad \mathbf{H}) \\
\text { Ele desmaiou }\end{array}$ \\
\hline & $\left(\mathrm{L}^{\prime} \mathrm{H}\right) \mathrm{L}$ & $\begin{array}{l}\text { woor xop yun } \\
\text { (L H) } \mathbf{L} \\
\text { O tukano secou a roupa }\end{array}$ \\
\hline & (L'HL) L & $\begin{array}{l}\text { Tir baad yõor } \\
\text { (L } \mathbf{H L} \text { ) L } \\
\text { Ele virou o remédio }\end{array}$ \\
\hline & $\left(\mathrm{L}^{\prime} \mathrm{H}\right) \mathrm{H}$ & $\begin{array}{l}\text { Tir xop paa' } \\
\text { (L H) H } \\
\text { Ele secou o ombro } \\
\end{array}$ \\
\hline \multirow[t]{5}{*}{$\begin{array}{l}4 \text { sílabas/ } \\
\text { tons por } \\
\text { sentença }\end{array}$} & 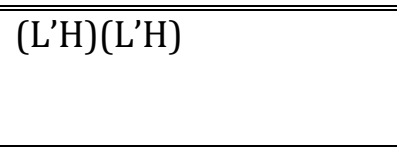 & 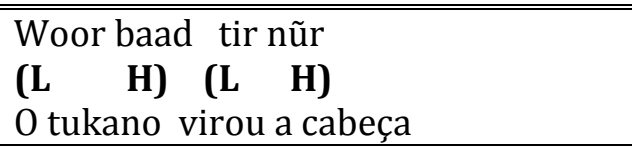 \\
\hline & $\left(\mathrm{L}^{\prime} \mathrm{H}\right)\left(\mathrm{L}^{\prime} \mathrm{H} \mathrm{L}\right)$ & 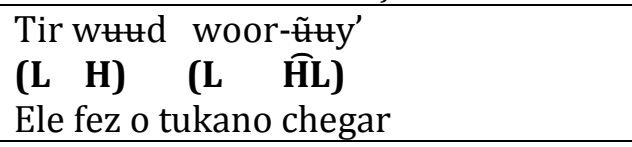 \\
\hline & (L L'H)L & $\begin{array}{l}\text { Woor dôo xop yun } \\
(\mathbf{L} \quad \mathbf{L} \quad \text { H) } \mathbf{L} \\
\text { O tukano secou a roupa }\end{array}$ \\
\hline & $\left(\mathrm{L} \mathrm{L}^{\prime} \mathrm{H}\right) \mathrm{H}$ & $\begin{array}{l}\text { buuy dôo xop paa } \\
\text { (L L H) (H) } \\
\text { O homem branco secou o ombro }\end{array}$ \\
\hline & $\left(\mathrm{L}^{\prime}{ }^{\prime} \mathrm{H}\right) \widehat{\mathrm{HL}}$ & $\begin{array}{l}\text { Woor dôo ‘ub pũug } \\
\text { (L } \quad \text { L 'H) THL } \\
\text { O tukano fez o porco-espinho acordar } \\
\end{array}$ \\
\hline $\begin{array}{l}\text { sílabas/ } \\
\text { tons por } \\
\text { sentença }\end{array}$ & (L L H) (L H) & $\begin{array}{l}\text { Tir dôo nõx dâr yun } \\
(\mathbf{L} \quad \mathbf{L} \text { ' H) } \quad \text { (L 'H) } \\
\text { Ele fez a roupa cair }\end{array}$ \\
\hline
\end{tabular}




\begin{tabular}{|c|c|c|}
\hline & (L L'H) (L'ThL) & 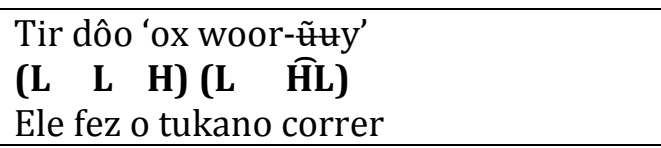 \\
\hline & $\left(\mathrm{L}^{\prime} \mathrm{L}^{\prime} \mathrm{H}\right)(\widehat{\mathrm{L}} \mathrm{H}$ ' $\mathrm{HL})$ & 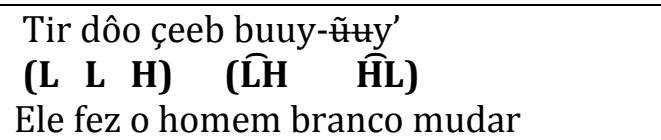 \\
\hline & (L L'ĤH)(L'HL) & $\begin{array}{l}\text { Tir dôo ‘ãa buuy-ũuy' } \\
\text { (L L } \text { HL) } \\
\text { Ele fez o homem branco dormir }\end{array}$ \\
\hline & $\widehat{\mathrm{L} H}\left(\mathrm{~L}^{\prime} \mathrm{H}\right)\left(\mathrm{L}^{\prime} \mathrm{HL}\right)$ & 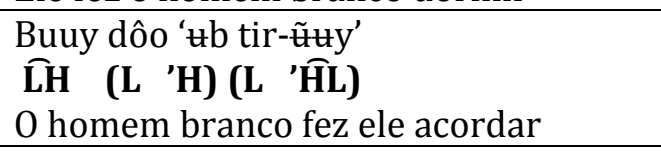 \\
\hline & $\widehat{\mathrm{L} H}\left(\mathrm{~L}^{\prime} \widehat{\mathrm{HL}}\right)\left(\mathrm{L}^{\prime} \mathrm{HL}\right)$ & 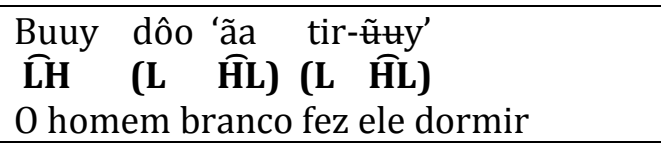 \\
\hline & $\mathrm{L}\left(\mathrm{L}^{\prime} \mathrm{H}\right)\left(\mathrm{L}^{\prime} \widehat{\mathrm{HL}}\right)$ & $\begin{array}{l}\text { woor dôo 'Hb tir-ũuy' } \\
\mathbf{L} \quad \text { (L 'H) (L'HL) } \\
\text { O homem branco fez ele acordar }\end{array}$ \\
\hline & $\left(L^{\prime} H\right)\left(L^{\prime}{ }^{\prime} H\right)$ & $\begin{array}{l}\text { tir pô dâr top yôor } \\
(\mathbf{L} \quad \mathbf{H})(\mathbf{L} \quad \mathbf{L} \quad \text { H) } \\
\text { Ele abriu a porta }\end{array}$ \\
\hline \multirow[t]{5}{*}{$\begin{array}{l}6 \text { sílabas/ } \\
\text { tons por } \\
\text { sentença }\end{array}$} & $\left(L^{\prime} H\right)\left(L^{\prime} H\right)\left(L^{\prime} H\right)$ & 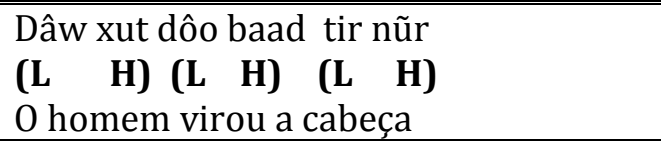 \\
\hline & (L'H)(L'H)(L'Ĥ) & 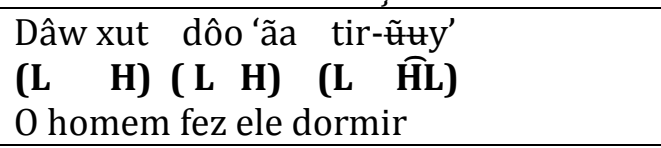 \\
\hline & L(L L'ĤL)(L'ThL) & $\begin{array}{l}\text { woor dôo kog'õogn } \\
\mathbf{L} \quad \mathbf{L} \quad \mathbf{L} \quad \widehat{\mathbf{H L}}) \\
\text { O tukano fez a anta desmaiar }\end{array}$ \\
\hline & $\widehat{\mathrm{L} H}\left(\mathrm{~L} \mathrm{~L}^{\prime} \widehat{\mathrm{HL}}\right)\left(\mathrm{L}{ }^{\prime} \mathrm{HL}\right)$ & 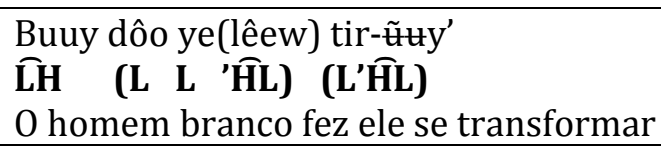 \\
\hline & L(L'H)(L L'Hิ) & $\begin{array}{l}\text { Tir dôo xop dâw tee-ũuy' } \\
\mathbf{L} \quad \text { (L 'H) (L } \quad \text { L 'HL) } \\
\text { Ele fez a criança secar }\end{array}$ \\
\hline \multirow[t]{3}{*}{$\begin{array}{l}7 \text { sílabas/ } \\
\text { tons por } \\
\text { sentença }\end{array}$} & ("L 'H) (L L’ H)(L’⿳⺈⿵冂) & 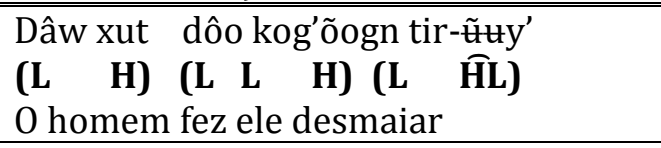 \\
\hline & $\left(\mathrm{L}^{\prime} \mathrm{H}\right)\left(\mathrm{L} \mathrm{L}^{\prime} \mathrm{HL}\right)\left(\mathrm{L}^{\prime} \mathrm{H} L\right)$ & 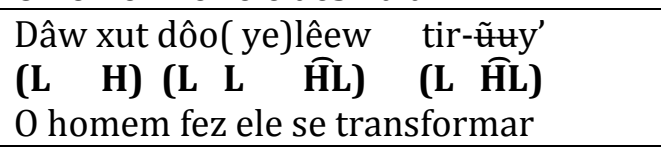 \\
\hline & $\left(\mathrm{L}^{\prime} \mathrm{H}\right)\left(\mathrm{L}^{\prime} \mathrm{H}\right)\left(\mathrm{L} \mathrm{L}^{\prime} \hat{\mathrm{H}} \mathrm{L}\right)$ & 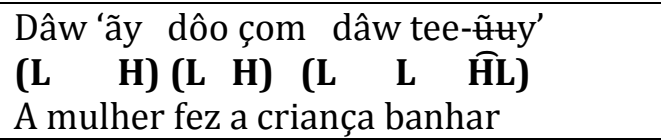 \\
\hline
\end{tabular}

As sentenças estudadas variam no número de sílabas que as compõem. Encontramos sentenças formadas por duas sílabas, cujo padrão tonal é (L 'H), três sílabas, (L L 'H), quatro sílabas, (L ‘H) (L ‘H), cinco sílabas, (L L ‘H) (L ‘H), seis sílabas, (L ‘H) (L ‘H) (L ‘H) e sete sílabas, (L ‘H) (L L ‘H) (L ‘HL). 
Em sentenças dissilábicas, observamos a composição de uma única frase fonológica com o padrão tonal ( $\mathrm{L}$ 'H); pode haver um tom de contorno opcional na última sílaba (L'⿳⺈⿴囗十) se esta é lexicalmente tonal. Esse tipo de contorno é sempre possível em sílabas acentuadas que possuem tom lexical. Opcionalmente, a primeira sílaba na frase fonológica pode carregar um tom de contorno ascendente $\left(\widehat{\mathrm{LH}}{ }^{\mathrm{H}} \mathrm{H}\right)$ se essa sílaba possui tom lexical. Este último tipo de contorno ocorre somente em sentenças dissilábicas.

Em sentenças trissilábicas, o padrão mais comum é a composição de uma frase fonológica cujo padrão tonal é ( $\mathrm{L}$ L 'H). Todavia, também é possível encontrar o seguinte padrão: (L 'H) L. Neste caso, a última sílaba corresponde a uma unidade prosódica (palavra fonológica) e sintática separada (como um verbo ou objeto, por exemplo).

O padrão tonal (L 'H) L não é muito frequente nos dados. ${ }^{7}$ Para esses casos, Storto, Costa e Andrade (em elaboração) mostram que, mesmo em isolamento, os tons de algumas palavras não correspondem ao seu tom lexical. Para esses casos, os autores postulam três regras aplicadas às sílabas não-fraseadas no final da sentença cujos tons lexicais são de contorno, isto é: $(\widehat{\mathrm{HL}})$ e $(\widehat{\mathrm{LH}}){ }^{8}$

(9) Regras tonais para sílaba não-fraseadas em final de sentença:

i) A sílaba não-fraseada se associa a um tom $\% \mathrm{~L}^{9}$ do fim do enunciado;

ii) Não é permitida no sistema da língua a ocorrência de tom de contorno em sílabas finais não-fraseadas;

iii) Quando há a ocorrência de mais de um tom em uma sílaba nãofraseada, o tom da esquerda é desligado.

Exemplo:

$$
\begin{array}{lll}
\text { Tir } & \text { 'eed } & \text { nẽeg } \\
(\mathrm{L} & \mathrm{H}) & \mathrm{L} \\
\text { 3PS } & \text { virar } & \text { mel } \\
\text { 'Ele virou o mel' }
\end{array}
$$

\footnotetext{
${ }^{7} 36 \%$ dos casos apresentados.

${ }^{8}$ Todavia, ainda não está claro como atuam essas regras, uma vez que nem todas as sílabas com tom de contorno e em posição de sílaba não-fraseada perdem seus tons lexicais.

${ }^{9} \mathrm{O}$ símbolo \% indica que o tom vem do enunciado.
} 
Nẽeg 'mel' possui tom lexical descendente ( $\widehat{\mathrm{HL}})$. Na sentença, esse tom se associa com um tom $\% \mathrm{~L}$ que vem do enunciado (tom defaut), formando uma sequência como: ( $\widehat{\mathrm{HL}} \% \mathrm{~L})$. Como não é permitida a ocorrência de tom de contorno em sílabas não-fraseadas, o tom da esquerda é apagado ( $\widehat{\mathrm{HL}} \% \mathrm{~L})$. Como os dois tons restantes (o tom L da sílaba e o tom $\% \mathrm{~L}$ do enunciado) são iguais, eles se associam em um único tom, sendo pronunciados na sílaba como um único tom $\mathrm{L}$.

Abaixo, apresentamos outro caso:

$\begin{array}{lll}\text { Tir } & \text { baad } & \text { weed } \\ (\mathrm{L} & \widehat{\mathrm{HL}}) & \mathrm{L} \\ \text { 3PS } & \text { virar } & \text { comida }\end{array}$

'Ele virou a comida'

Weed 'comida' possui tom lexical ascendente ( $\widehat{\mathrm{LH}})$. Na sentença, esse tom se associa com um tom $\% \mathrm{~L}$ que vem do enunciado (tom defaut), formando uma sequência como: ( $\widehat{\mathrm{LH}} \% \mathrm{~L})$. Como não é permitida a ocorrência de tom de contorno em sílabas não-fraseadas, o tom da esquerda é apagado ( $\widehat{\mathrm{EH}} \% \mathrm{~L})$. E como a sequência tonal continua formando tom de contorno na sílaba não-fraseada, novamente há a aplicação da terceira regra supracitada e o tom da esquerda é desligado ( $\# \% \mathrm{~L}$ ), restando um único tom L na sílaba isolada.

Em sentenças com quatro sílabas, o padrão mais comum é (L 'H) (L 'H). Nesses tipos de sentenças, também é possível encontrar sílabas não-fraseadas. Nesses casos, o padrão tonal é: (L L 'H) L, e a mesma regra acima referida é aplicada. Abaixo, apresentamos alguns exemplos:

\begin{tabular}{|c|c|c|c|}
\hline Woor & dôo & beg & mãam \\
\hline (L & $\mathrm{L}$ & $\mathrm{H})$ & $\mathrm{L}$ \\
\hline tukano & $\mathrm{CAI}$ & clare & $r$ feijão \\
\hline
\end{tabular}

\begin{tabular}{|c|c|c|c|}
\hline Woor & dôo & beg & naax \\
\hline (L & $\mathrm{L}$ & $\mathrm{H})$ & $\mathrm{L}$ \\
\hline tukano & $\mathrm{CAL}$ & clare & Ir água \\
\hline
\end{tabular}

Em (12), o item lexical em isolamento, mãam 'feijão', possui tom lexical descendente. Já em (13), o item lexical em isolamento, naax 'água', possui tom lexical 
ascendente. De forma semelhante a analisada nos exemplos (10) e (11), a aplicação das três regras tonais acima referidas gera tom (L) nos dois itens lexicais citados.

Além do padrão ( $\mathrm{L}$ L 'H) L, também observamos a ocorrência do seguinte padrão tonal em um dos exemplos elicitados: (L L 'H) H. Vejamos essa ocorrência:

$$
\begin{array}{llll}
\text { Tir } & \text { dôo } & \text { xop } & \text { paa' } \\
(\text { L } & \text { L } & \text { H) } & \text { H } \\
\text { 3PS } & \text { CAUS } & \text { secar } & \text { ombro }
\end{array}
$$

'Ele secou o ombro'

Analisamos esse dado como uma exceção às regras tonais para sílaba nãofraseadas. Paa' 'ombro' possui tom lexical ascendente $(\widehat{\mathrm{LH}})$. De acordo com as regras tonais, na sentença, esse tom se associaria a um tom $\% \mathrm{~L}$ que vem do enunciado e formaria a seguinte sequência: ( $\widehat{\mathrm{LH}} \% \mathrm{~L}$ ). Como não é permitida a ocorrência de tom de contorno em sílabas não-fraseadas no final do enunciado, o tom da esquerda é apagado ( $\widehat{\mathrm{EH}} \% \mathrm{~L})$. E como a sequência tonal continua formando tom de contorno na sílaba nãofraseada, haveria a aplicação da terceira regra tonal e o tom da esquerda é desligado (\# $\% \mathrm{~L}$ ), restando um único tom $\mathrm{L}$ na sílaba isolada. Todavia, acreditamos que a oclusiva glotal presente na palavra em análise, de algum modo, impede a ligação do tom ascendente ao tom \%L do enunciado, resultando na realização de um único tom ascendente. $\mathrm{O}$ tom à esquerda é desligado $(\widehat{\mathrm{EH}})$, resultando em uma sílaba de tom $(\mathrm{H})$, como pode ser visto no exemplo acima.

Tendo em vista a ocorrência registrada, Storto, Costa e Andrade (manuscrito) postulam mais uma regra para sílabas não-fraseadas em final de sentença em Dâw, a saber:

iv) A aplicação da regra (i) é anulada nos casos de sílabas que possuem glotais.

Em sentenças com cinco sílabas, o padrão tonal mais comum é a composição de uma frase fonológica formada por três sílabas seguida por uma frase formada por duas sílabas: (L L 'H) (L 'H). No entanto, também achamos padrões como os que seguem: (L 'H) (L L ’H), uma frase fonológica com duas sílabas seguidas por uma de três sílabas; L (L 'H) (L 'H) ou $\widehat{\mathrm{LH}}(\mathrm{L}$ 'H) (L 'H), uma sílaba não-fraseada no início da frase seguida por duas frases com duas sílabas cada. Nesses dois casos, a sílaba não fraseada corresponde a uma unidade prosódica (palavra fonológica) e sintática separada (como um sujeito). 
Já em início de sentença, Storto, Costa e Andrade (manuscrito) mostram que tons ascendentes podem ocorrer nessa posição. Quando há a ocorrência de mais de um tom em uma sílaba não-fraseada, o tom da direita é desligado, diferentemente de sílabas não-fraseadas em final de sentenças, no qual o tom à esquerda é que é desligado. Desse modo, os autores formulam as seguintes regras tonais para sílabas não-fraseadas em início de sentença:

(15) Regras tonais para sílaba não-fraseadas em início de sentença:

i) A sílaba não-fraseada se associa a um tom $\% \mathrm{~L}$ do enunciado.

ii) Quando há a ocorrência de mais de um tom em uma sílaba nãofraseada, o tom à direita é desligado.

Exemplo:

\begin{tabular}{|c|c|c|c|c|}
\hline Woor & dôo & baad & tir & nũr \\
\hline $\mathrm{L}$ & $(\mathrm{L}$ & $\mathrm{H})$ & $(\mathrm{L}$ & $\mathrm{H})$ \\
\hline tukano & CAU & S virar & 3PS & cabeça \\
\hline
\end{tabular}

Woor 'tukano' possui tom lexical ascendente $(\widehat{\mathrm{LH}})$. Na sentença, esse tom se associa com um tom $\% \mathrm{~L}$ que vem do enunciado (tom defaut), formando uma sequência como: (\% $\widehat{\mathrm{LH}}$ ). Como os dois tons iniciais (o tom $\mathrm{L}$ da sílaba e o tom \% $\mathrm{L}$ do enunciado) são iguais, eles se associam em um único tom, sendo pronunciados na sílaba como (L). Em seguida, é desligado o tom à direita da sequência tonal formada (\%L $\widehat{\mathrm{LH}})$ resultando em uma sílaba com um único tom (L).

Vejamos outro caso:

$\begin{array}{lclll}\text { Buuy } & \text { dôo } & \text { baad } & \text { tir } & \text { nũr } \\ \widehat{\mathrm{LH}} & (\mathrm{L} & \mathrm{H}) & (\mathrm{L} & \mathrm{H}) \\ \text { homem branco } & \text { CAUS virar } & \text { 3PS } & \text { cabeça } \\ \text { 'O homem branco fez a cabeça virar' } & \end{array}$

Buuy 'homem branco' possui tom lexical descendente ( $\widehat{\mathrm{HL}})$. Na sentença, esse tom se associa com um tom $\% \mathrm{~L}$ que vem do enunciado (tom defaut), formando uma sequência como: (\% $\widehat{\mathrm{HL}})$. O tom da direita é apagado (\% $\widehat{\mathrm{HE}})$ e no final da derivação, a sílaba não-fraseada é pronunciada com tom ascendente $(\widehat{\mathrm{LH}})$, pois há a associação do tom \%L do enunciado com o tom $(\mathrm{H})$ da sílaba.

Em sentenças com seis sílabas, o padrão mais comum é (L 'H) $(\mathrm{L}$ 'H) $(\mathrm{L}$ 'H). Porém, uma sílaba não-fraseada (L) também pode ficar à esquerda, no começo da 
sentença, se ela corresponde ao sujeito da sentença: L ( ${ }^{\prime}$ 'H) (L L 'H), ou L ( ${ }^{2}$ L 'H) ( $\left.\mathrm{L}^{\prime} \mathrm{H}\right)$.

Por fim, com relação às sentenças com sete sílabas, podemos encontrar três

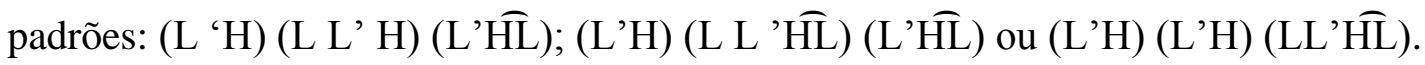

\subsubsection{Reanalisando a transitivização em Dâw}

Como pudemos perceber pela análise dos padrões tonais discutidos na seção anterior, a mudança tonal dos verbos não está relacionada especificamente ao processo de transitivização. Se isso fosse verdade, o tom dos verbos deveria alterar em cada membro do par da alternância causativo-incoativa, o que não ocorre. O tom lexical dos verbos se neutraliza na sentença de maneira previsível. Essa neutralização está associada ao fraseamento fonológico das sílabas que compõem as sentenças e é regido pelas regras do sistema de acento tonal, descritas na seção anterior.

A seguir, apresentamos alguns exemplos do processo de transitivização com o verbo alternante xop 'secar' e wutd 'chegar'. Organizamos os dados pelo contexto tonal, criado a partir do tom lexical do verbo em análise. Durante a elicitação, não encontramos verbos alternantes cujo tom lexical fosse ascendente.

Os exemplos estão organizados do seguinte modo: as sentenças estão divididas em contextos tonais: atonal (elicitação de verbos atonais composto com sujeito e objeto atonais, de tom ascendente e de tom descendente) e descendente (elicitação de verbos descendentes compostos com sujeito e objeto atonais, de tom ascendente e de tom descendente). Para cada verbo, há uma tabela informando o padrão tonal do verbo elicitado em quatro contextos distintos: tom lexical, de acordo com Martins (2004), tom na sentença intransitiva, tom na sentença transitivizada, tom na sentença causativizada.

$\mathrm{Na}$ primeira linha, transcrevemos a sentença em Dâw. Na segunda linha, transcrevemos o padrão tonal da sentença. Na terceira linha, seguem as glosas dos itens lexicais e gramaticais. Na quarta linha, é apresentada a tradução da sentença. 
Contexto atonal

○ xop - secar

\begin{tabular}{c|c|c|c}
\hline $\begin{array}{c}\text { Tom lexical } \\
\text { (Martins, 2004) }\end{array}$ & $\begin{array}{c}\text { Tom na sentença } \\
\text { intransitiva }\end{array}$ & $\begin{array}{c}\text { Tom na sentença } \\
\text { transitivizada }\end{array}$ & $\begin{array}{c}\text { Tom na sentença } \\
\text { causativizada }\end{array}$ \\
\hline Atonal & $\mathrm{H}$ & $\mathrm{H}$ & $\mathrm{H}$ \\
\hline
\end{tabular}

- S atonal $+\mathrm{V}$ atonal

a) yun xop

( $\mathrm{L} \quad \mathrm{H})$

roupa secar

'A roupa secou'

- $\mathbf{S}$ atonal $+(\mathbf{d o ̂ o})+\mathrm{V}$ atonal+ $\mathbf{O}$ atonal

b) Tir xop yun

$\left(\begin{array}{lll}\mathrm{L} & \mathrm{H}\end{array}\right) \quad \mathrm{L}$

3PS secar roupa

'Ele secou a roupa'

c) Tir dôo xop yun

$\left(\begin{array}{llll}\mathrm{L} & \mathrm{L} & \mathrm{H}\end{array}\right) \quad \mathrm{L}$

3PS CAUS secar roupa

'Ele secou a roupa'

- S ascendente $+\mathbf{V}$ atonal

(19)

a) Paa' xop

$(\widehat{\mathrm{LH}} \mathrm{H})$

ombro secar

'O ombro secou'

- S atonal+ (dôo) $+\mathrm{V}$ atonal $+\mathbf{O}$ ascendente

b) Tir xop paa'

$\left(\begin{array}{lll}\mathrm{L} & \mathrm{H}\end{array}\right) \quad \mathrm{H}$

3PS secar ombro

'Ele secou o ombro' 
c) Tir dôo xop paa'

$\left(\begin{array}{llll}\mathrm{L} & \mathrm{L} & \mathrm{H}\end{array}\right) \quad \mathrm{H}$

3PS CAUS secar ombro

'Ele secou o ombro'

- $\mathbf{S}$ descendente $+\mathrm{V}$ atonal

(20) a) Mãam xop

( $\left.\begin{array}{ll}\mathrm{L} & \mathrm{H}\end{array}\right)$

machado secar

'O machado secou'

- S atonal + (dôo) $+\mathrm{V}$ atonal $+\mathbf{O}$ descendente

b) Tir xop mãam

(L H) $\widehat{\mathrm{LH}}$

3PS secar machado

'Ele secou o machado'

c) Tir dôo xop mãam

(L $\left.\begin{array}{lll}\mathrm{L} & \mathrm{H}\end{array}\right) \quad \widehat{\mathrm{LH}}$

3PS CAUS secar machado

'Ele secou o machado'

- S atonal $+\mathrm{V}$ atonal

(21)

a) Yun xop

( $\left.\begin{array}{ll}\mathrm{L} & \mathrm{H}\end{array}\right)$

roupa secar

'A roupa secou'

- S ascendente $+($ dôo $)+V$ atonal +0 atonal

b) Woor xop yun

( $\left.\begin{array}{ll}\mathrm{L} & \mathrm{H}\end{array}\right) \quad \mathrm{L}$

tukano secar roupa

'O tukano secou a roupa' 

c) Woor dôo
xop yun
(L $\quad \mathrm{L}$
H) L
tukano CAUS
secar roupa
'O tukano secou a roupa'

- S ascendente $+\mathrm{V}$ atonal

(22)
a) Paa' xop
$(\widehat{\mathrm{LH}} \mathrm{H})$
ombro secar
'O ombro secou'

- S ascendente $+($ dôo $)+V$ atonal +0 ascendente
b) Woor
xop paa'
tukano
secar ombro
$(\mathrm{L}$
H) $\quad \mathrm{H}$
'O tukano secou o ombro'
c) Woor dôo xop paa'

$\left.\begin{array}{llll}(\mathrm{L} & \mathrm{L} & \mathrm{H}\end{array}\right) \mathrm{H}$
tukano CAUS secar ombro
'O tukano secou o ombro'

- S descendente $+\mathrm{V}$ atonal

(23)
a) Mãam xop
$(\widehat{\mathrm{LH}} \quad \mathrm{H})$
machado secar
'O machado secou'

- $\mathbf{S}$ ascendente $+($ dôo $)+V$ atonal +0 descendente
b) Woor
xop mãam
(L
H) $\widehat{\mathrm{LH}}$
Tukano
secar machado
'O tukano secou o machado' 

c) Woor dôo
xop mãam
$\mathrm{L} \quad(\mathrm{L}$
H) $\widehat{\mathrm{LH}}$
tukano CAUS
secar machado
'O tukano secou o machado'

- S atonal $+\mathrm{V}$ atonal

(24)

a) Yun xop

$\left(\begin{array}{ll}\mathrm{L} & \mathrm{H}\end{array}\right)$

roupa secar

'A roupa secou'

- S descendente+ (dôo) $+\mathrm{V}$ atonal $+\mathbf{O}$ atonal
b) Buuy
xop yun
(L
H) L
homem branco
secar roupa
'O homem branco secou a roupa'
c) Buuy
dôo xop yun
$(\mathrm{L}$
$\begin{array}{lll}\mathrm{L} & \mathrm{H}) \quad \mathrm{L}\end{array}$
homem branco
CAUS secar roupa
'O homem branco secou a roupa'

- S ascendente $+\mathrm{V}$ atonal

(25)
a) Paa'
xop
$(\widehat{\mathrm{LH}}$
$\mathrm{H})$
ombro
secar
'O ombro secou'

- $\mathbf{S}$ descendente $+(\mathrm{dôo})+\mathrm{V}$ atonal $+\mathbf{O}$ ascendente
b) Buuy
xop paa'
(L
H) $\quad \mathrm{H}$
homem branco
secar ombro
'O homem branco secou o ombro' 
c) Buuy

(L

homem branco dôo

$\mathrm{L}$

CAUS

'O homem branco secou o ombro' xop paa'

H) $\quad \mathrm{H}$

secar ombro

- S descendente $+\mathrm{V}$ atonal
a) Mãam xop
$(\widehat{\mathrm{LH}}$
H)
machado secar
'O machado secou'

- S descendente + (dôo) $+\mathrm{V}$ atonal $+\mathbf{O}$ descendente
b) Buuy
xop mãam
(L
H) $\widehat{\mathrm{LH}}$
homem branco
secar machado
'O homem branco secou o machado'
c) Buuy
dôo xop mãam
$(\widehat{\mathrm{LH}}$
L H) $\widehat{\mathrm{LH}}$
homem branco
CAUS secar machado
'O homem branco secou o machado'

No nível da sentença, o verbo atonal xop 'secar' (assim como os verbos pêt 'quebrar' e $p \hat{o}$ 'abrir') passam por mudanças tonais. No entanto, diferentemente do que afirma Martins (2004), essa mudança tonal não ocorre apenas nas sentenças cujos verbos são transitivizados (o que poderia sugerir que a mudança tonal decorreria desse processo), mas observamos que há mudança tonal do verbo (em relação ao seu tom lexical) nos três tipos de sentenças estudadas - sentenças intransitivas, transitivizadas e causativizadas - e em todos os ambientes de composição tonal, ou seja, ambiente atonal, descendente e ascendente.

Desse modo, independentemente do processo de aumento de valência envolvido, o mesmo tom $(\mathrm{H})$ permanece nas três sentenças estudadas. Logo, não identificamos um morfema tonal transitivizador nas sentenças elicitadas acima. 


\section{Contexto descendente}

○ wutd - chegar

\begin{tabular}{c|c|c|c}
\hline $\begin{array}{c}\text { Tom lexical } \\
\text { (Martins, 2004) }\end{array}$ & $\begin{array}{c}\text { Tom na sentença } \\
\text { intransitiva }\end{array}$ & $\begin{array}{c}\text { Tom na sentença } \\
\text { transitivizada }\end{array}$ & $\begin{array}{c}\text { Tom na sentença } \\
\text { causativizada }\end{array}$ \\
\hline$\widehat{\mathrm{HL}}$ & $\mathrm{H} / \widehat{\mathrm{HL}}$ & $\mathrm{H}$ & $\mathrm{H}$ \\
\hline
\end{tabular}

- S atonal -V descendente

(27)
a) Tir wutd
(L HL)
'Ele chegou'

- S atonal $-\mathrm{V}$ descendente $-\mathbf{O}$ atonal

b) Dâw xut dôo wutd tir-ũuy'
(L
H) $\quad(\mathrm{L}$
H)
(L $\widehat{\mathrm{HL}})$

gente macho CAUS chegar 3PS-MDO

'O homem fez ele chegar'

c) Dâw xut wutd tir-ũuy'

$\left(\begin{array}{llll}\mathrm{L} & \mathrm{L} & \mathrm{H}\end{array}\right) \quad(\mathrm{L} \quad \widehat{\mathrm{HL}})$

gente macho chegar 3PS-MDO

'O homem fez ele chegar'

- S ascendente $-V$ descendente

(28) a) Woor wutd

$\left(\begin{array}{ll}\mathrm{L} & \mathrm{H}\end{array}\right)$

tukano chegar

'O tukano chegou' 
- S atonal $-\mathrm{V}$ descendente -0 atonal

b) Tir wutd woor-ũuy'

$\left(\begin{array}{lll}\mathrm{L} & \mathrm{H}\end{array}\right) \quad(\mathrm{L} \quad \widehat{\mathrm{HL}})$

3PS chegar tukano-MDO

'Ele fez o tukano chegar'

c) Tir dôo wutd woor-ũuy'

$\left(\begin{array}{lllll}\mathrm{L} & \mathrm{L} & \mathrm{H}\end{array}\right) \quad\left(\begin{array}{ll}\mathrm{L} & \widehat{\mathrm{HL}}\end{array}\right)$

3PS CAUS chegar tukano-MDO

'Ele fez o tukano chegar'

- S descendente $-\mathrm{V}$ descendente

(29)

a) Buuy wutd

$(\mathrm{L} \quad \mathrm{H})$

homem branco chegar

'O homem branco chegou'

- S atonal -V descendente - $\mathbf{O}$ descendente

b) Tir wutd buuy-ũuy'

$\left(\begin{array}{llll}\mathrm{L} & \mathrm{H}\end{array}\right) \quad(\mathrm{L} \quad \widehat{\mathrm{HL}})$

3PS chegar homem branco-MDO

'Ele fez o homem branco chegar'

c) Tir dôo wutd buuy-ũuy'

$\left(\begin{array}{lllll}\mathrm{L} & \mathrm{L} & \mathrm{H}\end{array}\right) \quad\left(\begin{array}{ll}\mathrm{L} & \widehat{\mathrm{HL}}\end{array}\right)$

3PS CAUS chegar homem branco-MDO

'Ele fez o homem branco chegar'

- S atonal $+\mathrm{V}$ descendente

(30) a) Tir wutd

(L HL)

3PS chegar

'Ele chegou' 
- $\mathrm{S}$ ascendente $+\mathrm{V}$ descendente +0 atonal

b) Woor wutd tir-ũuy'

$\left(\begin{array}{llll}\mathrm{L} & \mathrm{H}\end{array}\right) \quad\left(\begin{array}{ll}\mathrm{L} & \widehat{\mathrm{HL}}\end{array}\right)$

tukano chegar 3PS-MDO

'O tukano fez ele chegar'

c) Woor dôo wut tir-ũuy'

$\left(\begin{array}{llll}\mathrm{L} & \mathrm{L} & \mathrm{H}\end{array}\right) \quad(\mathrm{L} \quad \mathrm{HL})$

tukano CAUS chegar 3PS-MDO

'O tukano fez ele chegar'

- S atonal + V descendente

(31)
a) Tir wutd
(L $\widehat{\mathrm{HL}}$ )
3PS chegar

'Ele chegou'

b) buuy

$(\mathrm{L}$

homem branco wutd tir-ũuy'

H) (L $\widehat{\mathrm{HL}})$

chegar 3PS-MDO

'O homem branco fez ele chegar'

c) Buuy

$\widehat{\mathrm{LH}}$

homem branco dôo wutd tir-ũuy'

(L $\mathrm{H}) \quad(\mathrm{L} \mathrm{HL})$

CAUS chegar 3PS-MDO

'O homem branco fez ele chegar'

- S ascendente $+\mathrm{V}$ descendente

(32)
a) Taax wutd
anta chegar
(L $\widehat{\mathrm{HL}}$ )

'A anta chegou' 
- $\mathrm{S}$ ascendente $+\mathrm{V}$ ascendente $+\mathbf{O}$ ascendente

b) Woor wutd taax-ũuy'
$\left(\begin{array}{llll}\mathrm{L} & \mathrm{H}\end{array}\right) \quad(\mathrm{L} \quad \hat{\mathrm{HL}})$

tukano chegar anta-MDO

'O tukano fez a anta chegar'

c) Woor dôo wut taax-ũuy'
(L L
H) $\quad\left(\begin{array}{ll}\mathrm{L} & \widehat{\mathrm{HL}}\end{array}\right.$

tukano CAUS chegar anta-MDO

'O tukano fez a anta chegar'

- $\quad$ S ascendente $+V$ descendente
a) Taax wutd
anta chegar
(L $\widehat{\mathrm{HL}})$

'A anta chegou'

- S descendente $+\mathrm{V}$ ascendente +0 ascendente

b) Buuy

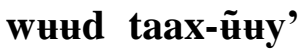

(L

H) (L $\widehat{\mathrm{HL}})$

homem branco

chegar anta-MDO

O homem branco fez a anta chegar
c) Buuy
dôo wut taax-ũuy
$\widehat{\mathrm{LH}}$
$\left(\begin{array}{llll}\mathrm{L} & \mathrm{H}\end{array}\right) \quad\left(\begin{array}{ll}\mathrm{L} & \widehat{\mathrm{HL}}\end{array}\right)$
homem branco
CAUS chegar anta-MDO
'O homem branco fez a anta chegar'

- S ascendente $+\mathrm{V}$ descendente

(34)
a) Pũug
wutd
(L
HL)
porco espinho chegar
'O porco espinho chegou' 
- $\mathrm{S}$ ascendente $+\mathrm{V}$ descendente +0 descendente

b) Woor wutd pũug-ũuy'

$\left(\begin{array}{lll}\mathrm{L} & \mathrm{H}\end{array}\right) \quad(\mathrm{L} \quad \widehat{\mathrm{HL}})$

tukano chegar porco espinho-MDO

'O tukano fez o porco espinho chegar'

c) Woor dôo wutd pũug-ũuy'
(L L
H) $\quad(\mathrm{L} \quad \widehat{\mathrm{HL}})$

tukano CAUS chegar porco espinho-MDO

'O tukano fez o porco espinho chegar'

- S ascendente $+\mathrm{V}$ descendente
a) Pũug
wethd
(L
HL)
porco espinho chegar
'O porco espinho chegou'

- $\mathrm{S}$ descendente $+\mathrm{V}$ descendente $+\mathrm{O}$ ascendente

b) Buuy

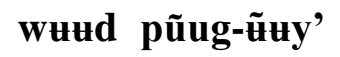

(L

H) ( $\begin{array}{ll}\mathrm{L} & \mathrm{HL}\end{array}$

homem branco chegar porco espinho-MDO

'O homem branco fez o porco espinho chegar'

c) Buuy

$\widehat{\mathrm{LH}}$

homem branco dôo wutd pũug-ĩuy'

$\left(\begin{array}{llll}\mathrm{L} & \mathrm{H}\end{array}\right) \quad(\mathrm{L} \quad \widehat{\mathrm{HL}})$

CAUS chegar porco espinho-MDO

'O homem branco fez o porco chegar'

No nível da sentença, o verbo de tom lexical descendente wuttd 'chegar' (assim como os verbos baad 'virar', 'eed 'virar' e bâar 'derramar') passa por mudanças tonais. Nas três sentenças estudadas - intransitivas, transitivizadas e causativas - o verbo em questão é pronunciado com tom alto $(\mathrm{H})$, independentemente do processo de aumento de valência envolvido. Com relação às sentenças intransitivas, em alguns exemplos, o verbo foi pronunciado com tom de contorno ( $\widehat{\mathrm{HL}})$, mas essa ocorrência é prevista, uma vez que, em posição final e inicial de uma sentença, verbos tonais em isolamento podem 
apresentar contorno, como já foi discutido anteriormente. Desse modo, à semelhança do que foi discutido para os verbos atonais, não foi identificada, com esses verbos, a presença de um morfema tonal transitivizador nas sentenças elicitadas.

Tendo em vista o padrão tonal observado nas sentenças elicitadas, constatamos que a transitivização em Dâw não ocorre por meio de morfemas explícitos. Assim, concluímos que o processo de transitivização em Dâw é do tipo lábil, no qual a mesma raiz verbal é encontrada em sentenças intransitivas e causativas.

\subsubsection{Reanalisando o processo de intransitivização em Dâw}

Tendo em vista os padrões tonais encontrados no nível sentencial, como discutimos nas seções anteriores, os tons dos verbos em isolamento (conforme consta em Martins, 2004) são neutralizados no nível da sentença. Isso não ocorre devido ao processo de transitivização ou causativização na língua, mas decorre de um padrão tonal previsível presente nas sentenças elicitadas.

Da mesma forma como reanalisamos o processo de transitivização em Dâw, também reanalisamos o processo de intransitivização que, a nosso ver, não condiciona mudanças tonais dos verbos, isto é, apagamento tonal, conforme analisa Martins (2004).

Como veremos com mais detalhes no capítulo 6 , de modo geral, percebemos que não há morfologia específica para a construção de sentenças médias, incoativas ou anticausativas em Dâw ${ }^{10}$. Quanto aos tons dos itens lexicais presentes nessas sentenças, eles seguem o mesmo padrão tonal encontrado nas sentenças transitivizadas e causativizadas, como podemos ver nos exemplos a seguir:

○ Rõk - cortar

\begin{tabular}{c|c|c|c}
\hline $\begin{array}{c}\text { Tom lexical } \\
\text { (Martins, 2004) }\end{array}$ & $\begin{array}{c}\text { Tom na sentença } \\
\text { transitiva }\end{array}$ & $\begin{array}{c}\text { Tom na sentença } \\
\text { intransitivizada }\end{array}$ & $\begin{array}{c}\text { Tom na sentença } \\
\text { média }\end{array}$ \\
\hline Atonal & $\mathrm{H}$ & $\mathrm{H}$ & $\mathrm{L}$ \\
\hline
\end{tabular}

${ }^{10}$ A metodologia para a elicitação de sentenças intransitivizadas está presente no capítulo 2, seção 2.2.2.1. 
(36)

a) Woor rõk tor-ũuy'

$\left(\begin{array}{lll}\mathrm{L} & \mathrm{H}\end{array}\right) \quad(\mathrm{L} \quad \widehat{\mathrm{HL}})$

tukano cortar porco-MDO

'O homem cortou o porco'

b) Tor rõk yutam

Tor rõk yu tam

$\left(\begin{array}{llll}\mathrm{L} & \mathrm{H}\end{array}\right) \quad(\mathrm{L} \quad \widehat{\mathrm{HL}})$

Porco cortar ASPC

'O porco já cortou'

c) Tor rõk xet

$\left(\begin{array}{lll}\mathrm{L} & \mathrm{L} & \mathrm{H}\end{array}\right)$

porco cortar rápido

'Porco corta rápido'

O verbo transitivo atonal $r \tilde{k} k$ 'cortar', na sentença transitiva e intransitivizada, é pronunciado com tom alto $(\mathrm{H})$; já na sentença média, é pronunciado com tom baixo (L). Essa ocorrência de tom se justifica tendo em vista a organização das sílabas da sentença em frases fonológicas. Assim, em (36a) e (36b), o verbo rõk 'cortar' é núcleo de uma frase fonológica dissilábica cujo padrão tonal é (L H); já em (36c), ele não é núcleo da frase fonológica (logo não é pronunciado com tom alto) que é formada por três sílabas: (L L H).

○ Nee - fazer

\begin{tabular}{c|c|c|c}
\hline $\begin{array}{c}\text { Tom lexical } \\
\text { (Martins, 2004) }\end{array}$ & $\begin{array}{c}\text { Tom na sentença } \\
\text { transitiva }\end{array}$ & $\begin{array}{c}\text { Tom na sentença } \\
\text { intransitivizada }\end{array}$ & $\begin{array}{c}\text { Tom na sentença } \\
\text { média }\end{array}$ \\
\hline$\widehat{\mathrm{HL}}$ & $\mathrm{H}$ & $\mathrm{L}$ & $\mathrm{L}$ \\
\hline
\end{tabular}

\begin{tabular}{|c|c|c|c|}
\hline Dâw & xut & nee & kedrẽ \\
\hline Dâw & xut & nee & ked \\
\hline (L & $\mathrm{L}$ & $\mathrm{H})$ & (L \\
\hline gente & macl & fazer & colar \\
\hline
\end{tabular}




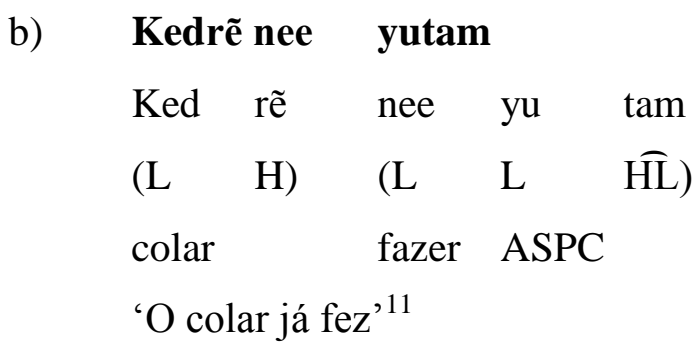

c) Kedrẽ nee xet

$\begin{array}{llll}\text { Ked } & \text { rẽ } & \text { nee } & \text { xet } \\ \left(\begin{array}{lll}L & H\end{array}\right) & \left(\begin{array}{ll}L & H\end{array}\right) \\ \text { colar } & \text { faz } & \text { fácil } & \end{array}$

'Colar faz fácil'

$\mathrm{Na}$ sentença transitiva, o verbo descendente nee 'fazer' é núcleo da frase fonológica trissilábica (logo ele é pronunciado com tom alto $(\mathrm{H})$ ). Nessa frase, o padrão fonológico é (L L H). Já nas sentenças intransitivizada e média, o verbo é pronunciado com tom baixo (L). Essa ocorrência de tom se justifica tendo em vista a organização das frases fonológicas que compõem as sentenças. Assim, na sentença intransitivizada (37b), o verbo não é núcleo e ocupa a primeira posição de uma frase trissilábica (L L $\widehat{\mathrm{HL}}$ ). Na sentença média, o verbo ocupa a primeira posição da frase dissilábica (L H). Assim, à semelhança da sentença intransitivizada, o verbo também não é núcleo da frase fonológica e não é pronunciado por tom alto $(\mathrm{H})$.

Tendo em vista os padrões tonais apresentados, pudemos notar, pelos dados coletados, que a mudança tonal dos verbos é previsível e não é condicionada por nenhum processo de diminuição de valência, como analisa Martins (2004).

\subsection{Síntese do capítulo}

Nesse capítulo, apresentamos e discutimos o sistema tonal da língua Dâw e a sua relação com o processo de transitivização. Contrapusemos a análise de Martins (2004), acerca do sistema tonal e do processo de transitivização em Dâw, aos dados coletados em trabalho de campo e analisados por Storto, Costa e Andrade (em elaboração) e, contrariamente ao afirmado por Martins (2004), mostramos que o sistema tonal da

\footnotetext{
${ }^{11}$ Em português essa sentença seria considerada agramatial por alguns falantes, mas em Dâw, esse tipo de construção é gramatical, segundo os informantes.
} 
língua Dâw, no nível da sentença, é previsível e que os tons dos itens lexicais constituintes de uma sentença neutralizam-se e passam a ser pronunciados de acordo com padrões tonais previsíveis. Desse modo, independentemente do processo de aumento de valência envolvido, percebemos que a mudança tonal dos verbos decorre do fraseamento fonológico das sentenças e não da presença de um morfema tonal transitivizador. Concluímos que a transitivização em Dâw não ocorre por meio de morfemas explícitos, desse modo, o processo de aumento de valência em questão é do tipo lábil, no qual a mesma raiz verbal é encontrada em sentenças intransitivas e causativas, sem adição de morfologia em qualquer uma das formas. 


\section{Capítulo 5: Processos de aumento de valência em Dâw}

\subsection{Introdução}

Neste capítulo, discutimos o processo de transitivização e causativização em Dâw. A transitivização é um processo de formação de verbos transitivos a partir de uma raiz verbal intransitiva, raiz não-verbal, ou acategorial na qual é adicionado ao predicado verbal um argumento externo agente ou causa. A causativização, por sua vez, é um processo no qual um auxiliar causativo, adicionado ao predicado verbal, aumenta a valência do verbo, isto é, insere um argumento externo agente ou causa.

Como vimos no capítulo 4, divergimos da posição de Martins (2004) ao afirmar que em Dâw, o processo de transitivização está relacionado às mudanças tonais do verbo. Para a autora, verbos intransitivos podem ser transitivizados por meio do tom descendente $(\widehat{\mathrm{HL}})^{1}$, que se configuraria como um morfema de aumento de valência na língua.

Neste trabalho, argumentamos que os tons dos verbos em isolamento (conforme consta em Martins, 2004) mudam no nível da sentença, todavia, isso não ocorre devido ao processo de transitivização ou causativização na língua, mas devido a um padrão tonal previsível das sílabas que compõem uma sentença. Desse modo, observamos, por exemplo, que verbos atonais como pêt 'quebrar' passam por mudanças tonais no nível da sentença. No entanto, diferentemente do que afirma Martins (2004), essa mudança tonal não ocorre apenas nas sentenças cujos verbos são transitivizados (o que poderia sugerir que a mudança tonal decorre desse processo), mas a mudança tonal do verbo (em relação ao seu tom lexical) ocorre nos três tipos de sentenças estudados: sentenças intransitivas, transitivizadas e causativizadas.

Dessa forma, concluímos que a transitivização em Dâw não ocorre por meio de morfemas explícitos, uma vez que para nós o tom do verbo não é morfema de valência, contrariando a hipótese de Martins (2004).

Esse capítulo está organizado da seguinte forma: na seção 5.1, discutimos o processo de transitivização em Dâw e o background teórico desta pesquisa, Hale \&

\footnotetext{
${ }^{1} \mathrm{Na}$ ortografia, o tom é marcado por meio da duplicação da vogal que apresenta o tom. Para mais detalhes, ver capítulo 1.
} 
Keyser (2002); na seção 5.2, discutimos o processo de causativização; na seção 5.3, apresentamos uma síntese do capítulo.

\subsection{Transitivização em Dâw}

A transitivização em Dâw não ocorre por meio de morfemas explícitos. A mesma raiz verbal é encontrada no par da alternância do tipo causativo-incoativa, no qual um verbo intransitivo passa a transitivo, sendo que o sujeito do verbo intransitivo se torna objeto do verbo transitivizado (exemplo 1). Na literatura, esse tipo de alternância é denominado como alternância lábil ou alternância simples, como é observada em línguas como o português (exemplo 2) e o inglês (exemplo 3).

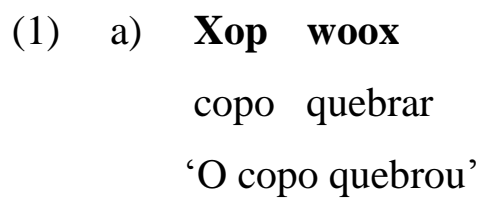

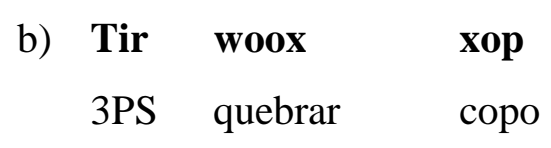

'Ele quebrou o copo'

(2) a) $\mathbf{O}$ copo quebrou

b) João quebrou o copo

(3) a) The vase broke

b) John broke the vase

Para autores como Hale \& Kayser (2002), esse tipo de transitivização pode ser denominado como transitivização automática ou simples, pois não há a necessidade da inserção de um núcleo causa na estrutura do verbo, capaz de projetar um agente causador presente na sentença causativizada. Como veremos adiante, a transitivização automática é uma propriedade que revela uma estrutura argumental específica sobre uma classe de verbos. Segundo Haspelmath (1993), verbos que alternam são, geralmente, verbos de mudança de estado. $\mathrm{O}$ verbo causativo possui um agente causador (quem causa o evento verbal); e o verbo incoativo não possui um agente, mas codifica o evento verbal como espontâneo. 
Segundo Hale \& Kayser (2002), esse tipo de transitivização difere de outros processos de aumento de valência como a causativização ou transitivização complexa, processo no qual a valência verbal é aumentada, pois é adicionado ao predicado verbal um argumento externo, por meio da inserção de um causativizador ou auxiliar. Nas próximas seções, esclareceremos essas definições.

Para o estudo do processo de transitivização em Dâw aplicamos o teste de alternância causativo-incoativa apenas com os verbos intransitivos. A metodologia desse teste encontra-se na seção 2.2.2 do capítulo 2 .

Como já foi dito, o teste de alternância causativo-incoativa ou transitivização automática (Hale \& Keyser, 2002) é um processo segundo o qual um verbo intransitivo passa a transitivo, sendo que o sujeito do verbo intransitivo se torna objeto do verbo transitivizado. Exemplo: (i) 'O dia clareou' (verbo intransitivo)/ (ii) 'O sol clareou o dia' (verbo transitivo). O argumento 'dia' é sujeito na oração (i) e objeto na oração (ii). Esse teste é importante na análise das classes verbais, pois ele revela propriedades específicas da estrutura argumental dos verbos, como, por exemplo, a existência, na língua de subclasses, de verbos intransitivos - como inergativos e inacusativos. Tal afirmação vai ao encontro da Hipótese Inacusativa, formulada por Perlmutter (1978) e desenvolvida por Burzio (1981).

Segundo essa teoria, a classe dos intransitivos pode ser dividida em duas subclasses tendo em vista sua configuração sintática, a saber: inergativo, que projeta apenas argumento externo; e inacusativo, que projeta apenas argumento interno. Desse modo, smile 'sorrir' é um verbo do tipo inergativo; seu sujeito é um argumento externo projetado em $v$ P (vezinho), acima de VP. Sink 'afundar' é um verbo inacusativo, que projeta um argumento interno em VP. Para receber caso nominativo (sujeito), o argumento sobe para a posição de especificador de IP. Nessa perspectiva, verbos intransitivos inacusativos podem participar da alternância causativo-incoativa, pois apenas esses verbos possuem um argumento interno, que em construções transitivas permanece in situ, recebendo caso acusativo (objeto).

A seguir, apresentamos uma tabela que compreende os 70 verbos intransitivos testados nesta pesquisa. 


\begin{tabular}{|c|c|c|c|}
\hline Número & Verbo em Dâw & Tradução & $\begin{array}{l}\text { Classificação de } \\
\text { Martins (2004) }\end{array}$ \\
\hline 1 & wutd & Chegar & Intransitivo \\
\hline 2 & baad & Virar & Intransitivo \\
\hline 3 & 'eed & Virar & Intransitivo \\
\hline 4 & bâar & Derramar & Intransitivo \\
\hline 5 & pêt & Quebrar & Intransitivo \\
\hline 6 & woox & Quebrar & Intransitivo \\
\hline 7 & xop & Secar & Intransitivo \\
\hline 8 & pô & Abrir & Intransitivo \\
\hline 9 & tobuk & Fechar & Intransitivo \\
\hline 10 & yapilu & Começar & Intransitivo \\
\hline 11 & çêe & Espalhar & Intransitivo \\
\hline 12 & rud & Derreter & Intransitivo \\
\hline 13 & $\mathrm{r} \tilde{\mathrm{u}}$ & Terminar & Intransitivo \\
\hline 14 & wâg & Balançar & Intransitivo \\
\hline 15 & pâd & Rolar & Intransitivo \\
\hline 16 & rã & Parar & Intransitivo \\
\hline 17 & leg & Apagar & Intransitivo \\
\hline 18 & 'ox & Correr & Intransitivo \\
\hline 19 & rôd & Sair & Intransitivo \\
\hline 20 & ‘ãa & Dormir & Intransitivo \\
\hline 21 & suuk & Caçar & Intransitivo \\
\hline 22 & yelêew & Transformar-se & Intransitivo \\
\hline 23 & kog'õogn & Desmaiar & Intransitivo \\
\hline 24 & çeeb & Mudar & Intransitivo \\
\hline 25 & ' $\mathrm{ub}$ & Acordar & Intransitivo \\
\hline 26 & çom & Banhar & Intransitivo \\
\hline 27 & win & Trabalhar & Intransitivo \\
\hline 28 & nõx & Cair & Intransitivo \\
\hline 29 & kũm & Afundar & Intransitivo \\
\hline 30 & pôw' & Boiar & Intransitivo \\
\hline 31 & pêg-saak & Crescer & Intransitivo \\
\hline 32 & sux & Esfarelar & Intransitivo \\
\hline 33 & 'õot & Chorar & Intransitivo \\
\hline 34 & çâk & Pular & Intransitivo \\
\hline 35 & roo' & Tossir & Intransitivo \\
\hline 36 & 'ô & Rir & Intransitivo \\
\hline 37 & âaw & Gritar & Intransitivo \\
\hline 38 & yũmrũ & Cantar & Intransitivo \\
\hline 39 & yam & Dançar & Intransitivo \\
\hline 40 & yok & Nadar & Intransitivo \\
\hline 41 & çâ & Saltar & Intransitivo \\
\hline 42 & leep & Brilhar & Intransitivo \\
\hline 43 & xaam & Vomitar & Intransitivo \\
\hline 44 & bax & Suar & Intransitivo \\
\hline 45 & bâay & Arrotar & Intransitivo \\
\hline
\end{tabular}




\begin{tabular}{l|l|l|l}
\hline 46 & baak & Soluçar & Intransitivo \\
\hline 47 & ratĩs & Espirrar & Intransitivo \\
\hline 48 & kas & Estragar & Intransitivo \\
\hline 49 & yum & Melhorar & Intransitivo \\
\hline 50 & rãm xo & Andar & Intransitivo \\
\hline 51 & xaw & Ferver & Processo \\
\hline 52 & beg & Clarear & Processo \\
\hline 53 & rõ & Queimar & Processo \\
\hline 54 & baax & Aparecer & Processo \\
\hline 55 & xub-sõk rãm & Estar triste & Estativo \\
\hline 56 & kub rãm & Estar escuro & Estativo \\
\hline 57 & rân rãm & Estar velho & Estativo \\
\hline 58 & duy rãm & Estar sujar & Estativo \\
\hline 59 & mẽn rãm & Ser curto & Estativo \\
\hline 60 & pêg rãm & Ser grande & Estativo \\
\hline 61 & ça rãm & Ser preto & Estativo \\
\hline 62 & lâk rãm & Ser magro & Estativo \\
\hline 63 & çii rãm & Ser azedo & Estativo \\
\hline 64 & dep rãm & Ser gordo & Estativo \\
\hline 65 & tâaw rãm & Estar bravo & Estativo \\
\hline 66 & kas rãm & Ser feio & Estativo \\
\hline 67 & muj rãm & Ser úmido & Estativo \\
\hline 68 & wê rãm & Estar molhado & Estativo \\
\hline 69 & sêj rãm & Estar cheio & Estativo \\
\hline 70 & wât rãm & Ser comprido & Estativo \\
\hline & & Veros ionstivs & \\
\hline
\end{tabular}

Tabela 5.0: Verbos intransitivos testados

O teste de alternância causativo-incoativa mostrou-nos que um grupo de verbos intransitivos pode alternar livremente entre uma forma transitiva e incoativa, enquanto que outro grupo não pode. Desse modo, dividimos a classe dos verbos intransitivos em duas subclasses:

i) Subclasse dos verbos alternantes: verbos intransitivos que alternam entre uma forma intransitiva e transitiva sem o acréscimo de nenhuma morfologia específica de aumento de valência, como visto nas sentenças em português o dia clareou e o sol clareou o dia (essa subclasse também pode ser denominada de inacusativa);

ii) Subclasse dos verbos não-alternantes: verbos que não alternam entre uma forma intransitiva e transitiva sem morfologia específica. Nas próximas seções, veremos que os verbos intransitivos que não alternam possuem três padrões distintos. Apenas a uma parte desta subclasse, pode-se atribuir uma propriedade inergativa. Outros verbos dessa mesma 
subclasse possuem características estativas e de inacusativos que não alternam.

A subclasse dos verbos alternantes é formada pelos 17 verbos, como vemos na tabela a seguir:

\begin{tabular}{c|l|l}
\hline Número & \multicolumn{1}{|c|}{ Verbo em Dâw } & \multicolumn{1}{c}{ Tradução } \\
\hline 1 & wutud & Chegar \\
\hline 2 & baad & Virar \\
\hline 3 & 'eed & Virar \\
\hline 4 & bâar & Derramar \\
\hline 5 & pêt & Quebrar \\
\hline 6 & woox & Quebrar \\
\hline 7 & xop & Secar \\
\hline 8 & pô & Abrir \\
\hline 9 & tobuk & Fechar \\
\hline 10 & yapilu & Começar \\
\hline 11 & çêe & Espalhar \\
\hline 12 & rud & Derreter \\
\hline 13 & rũ & Terminar \\
\hline 14 & wâg & Balançar \\
\hline 15 & pâd & Rolar \\
\hline 16 & rã & Parar \\
\hline 17 & leg & Apagar \\
\hline & & Tabela 5.1. Verbos intransitivos alternantes
\end{tabular}

Apresentamos os paradigmas completos de três verbos alternantes testados: wutt 'chegar', bâar 'derramar' e xop 'secar'. Os outros 14 verbos testados seguem o mesmo padrão desses três verbos. No item (a), apresentamos a sentença intransitiva; e no item (b), a sentença transitivizada.

(4)
a) Buuy
wutd
homem branco
chegar

'O homem branco chegou'

b) Tir wutd buuy-ũuy'

3PS chegar homem branco-MDO

'Ele fez o homem branco chegar (Lit.: Ele chegou o homem branco)'

(5) a) Naax bâar

água derramar

'A agua derramou' 


\section{b) Tir bâar naax \\ 3PS derramar água}

'Ele derramou a agua'

(6) a) Yun xop

roupa secar

'A roupa secou'

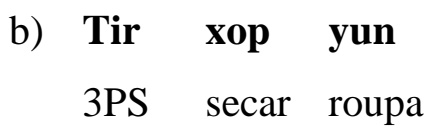

'Ele secou a roupa'

A subclasse dos verbos não-alternantes é formada pelos 53 verbos, como vemos na tabela a seguir:

\begin{tabular}{c|l|l}
\hline Número & \multicolumn{1}{|c|}{ Verbo em Dâw } & \multicolumn{1}{c}{ Tradução } \\
\hline 1 & 'ox & Correr \\
\hline 2 & rôd & Sair \\
\hline 3 & 'ãa & Dormir \\
\hline 4 & suuk & Caçar \\
\hline 5 & yelêew & Transformar-se \\
\hline 6 & kog'õogn & Desmaiar \\
\hline 7 & çeeb & Mudar \\
\hline 8 & 'ub & Acordar \\
\hline 9 & çom & Banhar \\
\hline 10 & win & Trabalhar \\
\hline 11 & nõx & Cair \\
\hline 12 & kũm & Afundar \\
\hline 13 & pôw' & Boiar \\
\hline 14 & pêg-saak & Crescer \\
\hline 15 & sux & Esfarelar \\
\hline 16 & 'õot & Chorar \\
\hline 17 & çâk & Pular \\
\hline 18 & roo’ & Tossir \\
\hline 19 & 'ô & Rir \\
\hline 20 & âaw & Gritar \\
\hline 21 & yũmrũ & Cantar \\
\hline 22 & yam & Dançar \\
\hline 23 & yok & Nadar \\
\hline 24 & çâ & Saltar \\
\hline 25 & leep & Brilhar \\
\hline 26 & xaam & Vomitar \\
\hline & & \\
\hline
\end{tabular}




\begin{tabular}{l|l|l}
\hline 27 & bax & Suar \\
\hline 28 & bâay & Arrotar \\
\hline 29 & baak & Soluçar \\
\hline 30 & ratĩs & Espirrar \\
\hline 31 & kas & Estragar \\
\hline 32 & yüm & Melhorar \\
\hline 33 & rãm xo & Andar \\
\hline 34 & xaw & Ferver \\
\hline 35 & beg & Clarear \\
\hline 36 & rõ & Queimar \\
\hline 37 & baax & Aparecer \\
\hline 38 & xub-sõ̃ rãm & Estar triste \\
\hline 39 & kub rãm & Estar escuro \\
\hline 40 & rân rãm & Estar velho \\
\hline 41 & duy rãm & Estar sujar \\
\hline 42 & mẽn rãm & Ser curto \\
\hline 43 & pêg rãm & Ser grande \\
\hline 44 & ça rãm & Ser preto \\
\hline 45 & lâk rãm & Ser magro \\
\hline 46 & çii rãm & Ser azedo \\
\hline 47 & dep rãm & Ser gordo \\
\hline 48 & tâaw rãm & Estar bravo \\
\hline 49 & kas rãm & Ser feio \\
\hline 50 & mutj rãm & Ser úmido \\
\hline 51 & wề rãm & Estar molhado \\
\hline 52 & sêj rãm & Estar cheio \\
\hline 53 & 'wât rãm & Ser comprido \\
\hline & & \\
\hline & &
\end{tabular}

Tabela 5.2: Verbos intransitivos não-alternantes

Apresentamos os paradigmas completos de quatro verbos não-alternantes: ' $o x$ 'correr', rôd 'sair', çâk 'pular' e çii rãm 'estar azedo'. Os outros verbos testados seguiram o mesmo padrão morfológico dos quatro verbos citados.

Como vimos no capítulo 3, o verbo çâk 'pular' é um verbo intransitivo denominal e o verbo çii rãm 'estar azedo' é a composição de uma cópula que toma como complemento um adjetivo. Assim, em Dâw não há uma classe de verbos deadjetivais derivada morfologicamente, como vemos em línguas como o português (curto (adjetivo), encurtar (verbo)) e uma escala menor no inglês (red (adjetivo), redden (verbo)), mas construções analíticas na qual o adjetivo não é verbalizado, sendo complemento de uma cópula. No item (a), apresentamos a sentença intransitiva e no item (b), a sentença transitivizada agramatical. 
(7) a) Woor 'ox

tukano correr

'O tukano correu'

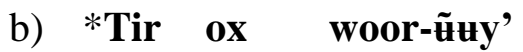

3PS correr tukano-MDO

(8) a) Woor rôd

tukano sair

'O tukano saiu'

b) *Tir rôd woor-ũuy'

3PS sair tukano-MDO

(9) a) $\mathbf{P u}$ çâk $\quad$ ø $\quad$ xâd

sapo pulo VERB ASPC/MV

'O sapo pulou'

b) *Dâw xut çâk p-ĩuy'

gente macho pulo sapo-MDO

(10) a) Weed çii rãm

comida azedo ficar

'A comida azedou (Lit,: A comida ficou azeda)'

b) *Yu' çii rãm weed

sol azedo ficar comida

Relacionando as propriedades sintáticas dos verbos supracitados com a proposta de Hale \& Keyser (2002), acreditamos que cada subclasse de verbos se caracteriza por um tipo específico de estrutura argumental que lhe capacita, ou não, alternar entre uma 
forma intransitiva e transitiva automaticamente, ou seja, sem a inserção de um causativizador ou morfema.

Nas próximas seções, apresentamos a teoria de Hale \& Keyser (2004) e faremos uma aproximação entre os dados do Dâw e as questões teóricas apresentadas.

\subsubsection{A teoria de Hale \& Keyser (2002)}

Segundo Hale \& Kayser (2002), a estrutura argumental é a configuração sintática projetada por um item lexical. Ela é determinada pelas configurações sintáticas geradas pela relação entre núcleo (item lexical) e argumento(s).

Tendo em vista essa premissa, para os autores, há dois tipos de relações fundamentais da estrutura argumental: núcleo-complemento; especificador-núcleo.

a) Núcleo-complemento (head-complement): Se X é o complemento de um núcleo $\mathrm{H}$, então X é o único irmão de $\mathrm{H}$ (X e $\mathrm{H}$ c-comandam um ao outro);

b) Especificador-núcleo (specifier-head): Se X é o especificador de um núcleo $\mathrm{H}$, e se P1 é a primeira projeção de H (i.e., H', necessariamente não-vazia), então X é o único irmão de $\mathrm{P}_{1}{ }^{2}$.(HALE \& KEYSER, 2002:2). ${ }^{3}$

Essas duas relações fundamentais na estrutura argumental definem algumas estruturas elementares:

a) Monádica: o núcleo projeta apenas um complemento e nenhum especificador.

b) Diádica básica: o núcleo projeta um complemento e um especificador.

c) Diádica composta: o núcleo projeta apenas um especificador e não um complemento. Este último argumento é gerado somente por composição com outro núcleo.

d) Atômica: o núcleo não projeta nem complemento, nem especificador.

Esses tipos estruturais variam entre as línguas. Em inglês, por exemplo, o núcleo apropriado para cada estrutura, respectivamente, é: a) verbo; b) preposição; c) adjetivo; d) nome.

\footnotetext{
${ }^{2}$ Tradução nossa.

3“a. Head-complement: if $X$ is the complement of a head $H$, then $X$ is the unique sister of $H$ (X and $\mathrm{H}$ c-command one another).

b. Specifier-head: if $X$ is the specifier of a head $H$, and Pl is the first projection of $H$ (i.e., $H^{\prime}$, necessarily nonvacuous), then $X$ is the unique sister of P1" (HALE \& KEYSER, 2002:2)..
} 
Nas próximas seções, apresentaremos uma discussão mais detalhada quanto às estruturas monádica, diádica básica e composta, estruturas cruciais para o entendimento dos dados do Dâw apresentados nesse capítulo.

\subsubsection{Estrutura Monádica}

A estrutura monádica é formada por dois elementos: uma raiz $(\mathrm{R})$ e um núcleo verbal (V).

(11)

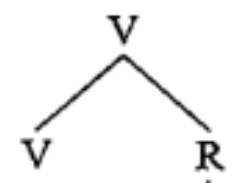

O núcleo verbal não projeta um especificador e o seu complemento, isto é, a raiz, também não motiva a projeção de um especificador. A natureza dessa raiz, na maior parte dos casos, é um nome (NP), que não projeta nem especificador, nem complemento (nomes possuem estrutura atômica). Verbos denominais ${ }^{4}$, como cough 'tossir' e dance 'dançar', são exemplos de verbos com esse tipo de estrutura. Em um primeiro momento, cough é gerado como um nome, na posição de raiz. O núcleo verbal, nesses casos, está vazio. A verbalização da forma nominal ocorre quando a matriz fonológica do nome passa para a posição estrutural de núcleo verbal por meio de conflation.

Conflation é um processo no qual a matriz fonológica do complemento do núcleo é introduzida na matriz fonológica vazia do núcleo que seleciona o complemento.

Desse modo, depois de transferir a matriz fonológica do complemento nominal para o núcleo verbal, gera-se um verbo sintético que não projeta especificador. Verbos intransitivos inergativos e alguns verbos transitivos possuem esse tipo de estrutura.

Uma característica importante desses tipos de verbos é a impossibilidade de sofrerem alternância sintática como apresentada no exemplo (12):

\footnotetext{
4 Alguns exemplos de verbos denominais, segundo Hale \& Kayser (2002:14): burp 'arrotar', cough 'tossir', cry 'chorar', dance 'dançar', gallop 'galopar', glitter 'brilhar', jump 'pular', laugh 'rir', limp 'limpar', run 'correr', scream 'gritar', shout, sleep 'dormir', sneeze 'espirrar', talk 'conversar', walk 'andar', entre outros.
} 
(12)

a) The engine coughed

'O motor tossiu'

\section{b) *I coughed the engine}

'Eu tossi o motor'

(HALE \& KEYSER, 2002:1)

A alternância apresentada acima é do tipo causativo-incoativa, na qual o sujeito do par intransitivo passa a ser objeto na sentença transitivizada. Verbos intransitivos com estrutura monádica não podem ser transitivizados automaticamente, pois, uma vez que eles não projetam especificador, não há um local na estrutura lexical em que o objeto da sentença transitiva possa ser projetado.

Os verbos monádicos compartilham propriedades sintáticas e lexicais com expressões verbais analíticas formadas a partir de verbos como make 'fazer'. Esse verbo transitivo também possui estrutura monádica e em construções analíticas não sofre conflation com o seu complemento. Desse modo, o complemento é realizado como objeto da sentença. O sujeito, por sua vez, é inserido na sintaxe sentencial, em um nível acima do da estrutura argumental. Assim, uma sentença como: He made a fuss 'ele fez uma bagunça', he não é argumento interno à configuração lexical projetada, mas um argumento externo gerado apenas na sintaxe sentencial.

(13) Expressão verbal analítica com make

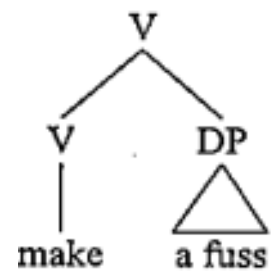

(HALE \& KAYSER, 2002:6)

Para a teoria de estrutura argumental de Hale \& Keyser (2002), o argumento externo não é um argumento interno à configuração projetada pelo item lexical, ele é gerado apenas na sintaxe sentencial. Para os autores, o sujeito é estruturalmente um adjunto do VP. Desse modo,

(...) um sujeito externo, sendo um adjunto a VP é, em um senso minimalista, "interno" ao VP, como na hipótese do sujeito interno ao VP, mas ele não é interno à configuração lexical projetada pelo núcleo lexical, uma vez que ele não ocupa nem a posição de complemento nem a posição de especificador de 
dentro da projeção. (HALE \& KEYSER, 2002: 249, nota 2 [tradução nossa]). ${ }^{5}$

Chomsky (1995) também distingue estruturalmente argumento externo e interno. Para o autor, este é gerado e recebe papel temático internamente ao VP, aquele é gerado e recebe papel temático na posição de Spec vP (vezinho) ${ }^{6}$. Para o autor, o sujeito é diferente de outros adjuntos, pois ele estabelece uma relação mais próxima com o verbo. Nesse trabalho, adotamos a representação das estruturas com $v \mathrm{P}$ para discutir a inserção do argumento externo na sentença. No trabalho de Hale \& Keyser (2002) essa posição é representada como um adjunto de VP.

\subsubsection{Estrutura diádica composta}

A estrutura diádica composta é formada por dois elementos: uma raiz $(\mathrm{R})$ e um hospedeiro verbal (V). Verbos gerados nessa estrutura projetam um especificador e um complemento. Todavia, o especificador e o complemento são exigidos por núcleos distintos dentro da estrutura. Assim, a raiz, geralmente realizada como um adjetivo, requer e projeta um especificador. O complemento é gerado somente por composição com outro núcleo.

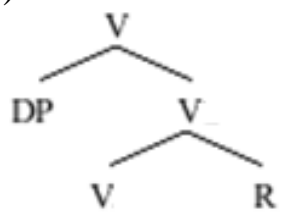

O núcleo V2 tem como complemento uma raiz de natureza adjetival. Os adjetivos possuem propriedades predicadoras e requerem semanticamente um especificador e não um complemento. Assim, na estrutura diádica composta, a raiz adjetival, por meio de conflation, passa a ocupar a posição de núcleo verbal V2 (fonologicamente nulo e que recebe a matriz fonológica do adjetivo) tornando-se um verbo. Esse núcleo verbal projeta uma estrutura que recebe o especificador projetado pela raiz da estrutura. Desse modo, é o complemento (i.e., raiz adjetiva) que tem a

\footnotetext{
5 "In this view of the matter, an external subject, being an adjunct to VP, is not internal to the lexical configuration projected by a lexical head, since it occupies neither a complement position nor a specifier position within that projection" (HALE \& KEYSER, 2002: 249, nota 2).

${ }^{6}$ Segundo o autor, "the external role is a property of the $v$-VP configuration, and a specifier bearing this role is therefore a necessary part of the configuration (...)" (CHOMSKY, 1995: 316).
} 
propriedade de requerer um especificador ${ }^{7}$. Essa estrutura é chamada de composta, pois a projeção do especificador interno depende de dois núcleos, a raiz, que o requer semanticamente, e núcleo verbal, que fornece uma estrutura para a projeção desse especificador.

O especificador é interno à projeção lexical. Verbos desse tipo, diferentemente dos verbos denominais de estrutura monádica, podem sofrer alternância causativoincoativa por meio de um processo de transitivização simples, ou automática. Na construção intransitiva (estrutura representada acima em (14)), o especificador da estrutura argumental também é sujeito na sintaxe sentencial. Para tanto, ele se move para Spec de IP para receber Caso nominativo. Apresentamos um exemplo de alternância causativo-incoativa com o verbo clear.

a) The screen cleared

'A janela limpou'

\section{b) I cleared the screen}

'Eu limpei a janela'

(HALE \& KEYSER, 2002:16)

O par transitivo do verbo é formado por meio do encaixamento da estrutura intransitiva (diádica composta) na posição de complemento de uma estrutura monádica. Esse encaixamento ocorre de forma puramente estrutural, através de merge entre os núcleos verbais monádico e diádico. O sujeito do par intransitivo, isto é, o especificador na estrutura argumental, é o objeto no par transitivo do verbo, o que evidencia que o especificador do verbo clear, de fato, é interno à projeção lexical. Apresentamos a representação do par intransitivo e transitivo do verbo clear após transitivização automática.

\footnotetext{
${ }^{7}$ Alguns exemplos de verbos deadjetivas retirados de Hale \&Keyser (2002:16): break 'quebrar', broaden 'alargar', crack 'rachar', darken 'escurecer', deepen 'aumentar', enlarge 'ampliar', freeze 'congelar', grow 'crescer', harden 'endurecer', lengthen 'alongar', loosen 'afrouxar', lower 'baixar', melt 'derreter', narrow 'estreitar', redden 'avermelhar', shorten 'encurtar', shrink 'encolher', sink 'afundar', soften 'amaciar', split 'dividir, partir', thicken 'engrossar', thin 'diluir, afinar', tighten 'esticar', widen 'alagar'.
} 
(16) a)

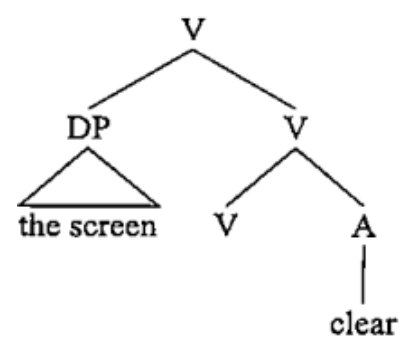

(HALE \& KEYSER, 2002:16)

b)

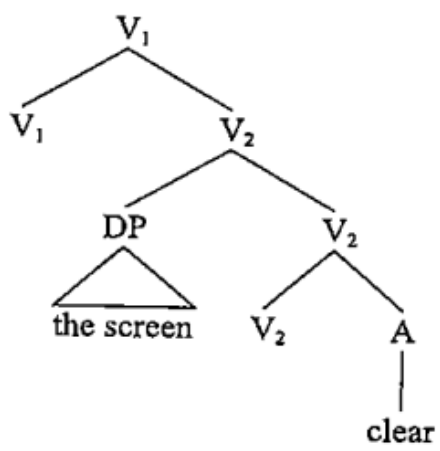

(HALE \& KEYSER, 2002:17)

Nessa representação, V1 é uma estrutura monádica que toma como complemento uma estrutura diádica composta. Nessa estrutura, há somente um verbo realizado, isto é, clear. A posição de núcleo verbal da estrutura monádica V1 está vazia. Essa posição é preenchida pela matriz fonológica do verbo deadjetival clear via conflation. A matriz do verbo é transferida do núcleo mais baixo para o núcleo mais alto, deixando um traço, na posição primária.

\subsubsection{Estrutura diádica básica}

Verbos de estrutura diádica básica são formados por dois elementos: um núcleo verbal (V) e uma preposição (P) que é complemento do núcleo verbal. Verbos gerados nessa estrutura projetam um especificador e um complemento. Esse requerimento é feito pelo núcleo preposicional que projeta dois argumentos internos. Vemos, a seguir, a representação da estrutura diádica básica. 
(17)

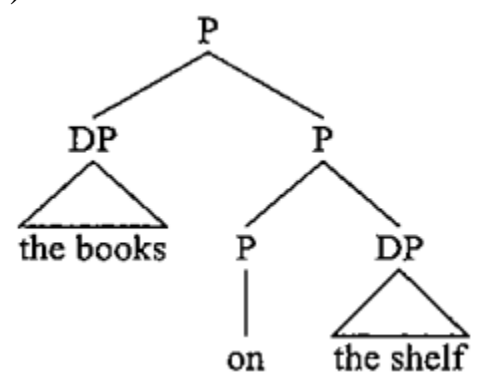

(HALE \& KEYSER, 2002:7)

A preposição, núcleo da estrutura diádica básica, especifica uma relação (que pode ser espacial, temporal, entre outras) entre duas entidades, eventos, etc. Isso define, para os autores, o caráter predicador da preposição, que, sendo núcleo, requer tanto especificador quanto complemento, diferentemente de nomes (que não requerem nenhum argumento) e adjetivos (que requerem apenas um argumento, o especificador).

A estrutura apresentada em (17) ainda não forma um verbo. Para a formação do predicado verbal, é necessário que a estrutura diádica básica seja encaixada a uma estrutura monádica, que a toma como complemento.

(18)

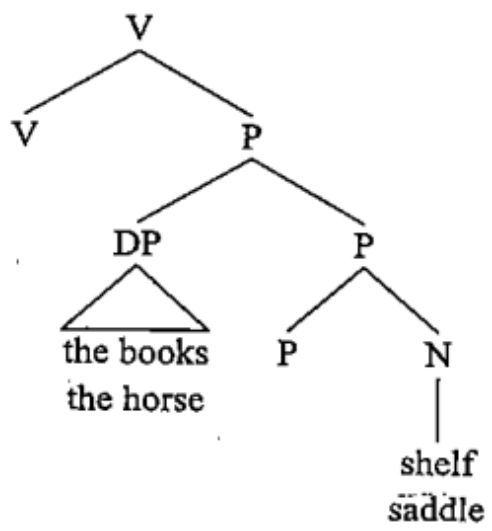

(HALE \& KEYSER, 2002:18)

Como vemos pela representação, a estrutura monádica introduz um núcleo verbal à estrutura diádica. Sendo vazio, ele pode sofrer conflation e receber a matriz fonológica do complemento de $\mathrm{P}$ (preposição e complemento), que também é produto de conflation entre o nome e a preposição. Desse processo, temos a construção das seguintes sentenças:

\section{a) I shelved the books}

'Eu emprateleirei os livros' 


\section{b) She saddled the horse}

'Ela selou o cavalo'

(HALE \& KEYSER, 2002:19)

Esse tipo de construção verbal é uma contraparte sintética para construções formadas com o verbo put, como vemos no exemplo a seguir:

\section{I put the books on the shelf}

'Eu coloquei os livros na prateleira'

(HALE \& KEYSER, 2002:6)

Essa estrutura, diferentemente da estrutura sintética, não apresenta um núcleo verbal vazio, e sim preenchido pelo verbo put 'colocar', núcleo da estrutura monádica. $\mathrm{O}$ especificador da projeção $\mathrm{P}$, na sintaxe sentencial, aparecerá como objeto da sentença, evidenciando que tal argumento, de fato, é um especificador interno à projeção lexical nucleada pela preposição. O sujeito, à semelhança do ocorrido com verbos monádicos, é um argumento externo introduzido na sintaxe sentencial. A seguir, mostramos a representação da construção analítica de verbos com estrutura diádica básica.

(21)

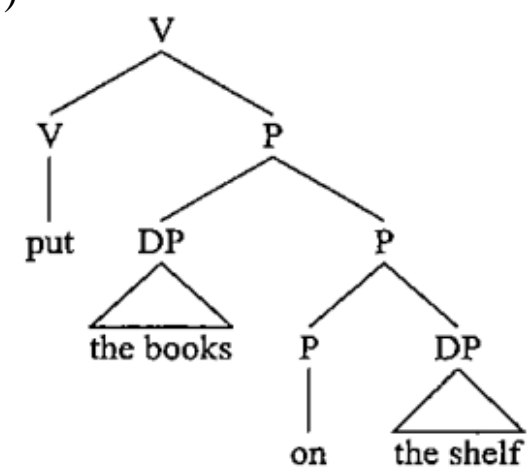

(HALE \& KEYSER, 2002:7)

A estrutura diádica básica pode dar origem a dois tipos de verbos: location $^{8} \mathrm{e}$ locatum $^{9}$. A diferença entre os dois verbos encontra-se nas propriedades semânticas da

\footnotetext{
${ }^{8}$ Alguns exemplos de verbos location extraídos de Hale \& Keyser (2002:18): bag 'empacotar', bank 'depositar', bottle 'engarrafar', box 'encaixotar', cage 'engaiolar', corral 'encurralar', crate 'encaixotar', jail 'enjaular', package 'embalar', photograph 'fotografar', pocket 'embolsar', shelve 'emprateileirar', entre outros.

${ }^{9}$ Alguns exemplos de verbos locatum extraídos de Hale \& Keyser (2002:18): bandage 'enfaixar', bar 'bloquear', blindfold 'vendar', bread 'empanar', butter 'amantegar', clothe 'vestir', curtain 'acortinar', oil 'lubrificar', paint 'pintar', saddle 'selar', salt 'salgar', seed 'semear', shoe 'ferrar', water 'regar', word 'redigir'.
} 
preposição presente como núcleo da projeção. Assim, o verbo location corresponde a estruturas cujo núcleo é uma preposição locativa como at, in, on, etc. A sentença (19a) é um exemplo desse tipo de verbo cuja estrutura analítica é: I put the books on the shelf 'Eu coloquei os livros na prateleira'. O verbo locatum corresponde a estruturas cujo núcleo é uma preposição de posse como with. A sentença (19b) é um exemplo desse tipo de verbo cuja estrutura analítica é: She put/left the horse with saddle 'Ela deixou o cavalo com sela'.

\subsubsection{Diálogo entre os dados da língua Dâw e a teoria de Hale \& Kayser (2002)}

Nesse trabalho, propomos que as subclasses de verbos intransitivos encontradas (alternantes e não-alternantes) caracterizam-se por um tipo específico de estrutura argumental que lhe capacita, ou não, alternar entre uma forma intransitiva e transitiva automaticamente, ou seja, sem a inserção de um causativizador ou morfema de aumento de valência.

Nas próximas seções, analisaremos as propriedades dessas estruturas argumentais à luz da teoria de Hale \& Keyser (2002) apresentada na seção anterior.

\subsubsection{A subclasse dos verbos alternantes ou inacusativa}

Como vimos na seção 5.1.1, para Hale \& Keyser (2002), verbos alternantes ou inacusativos possuem estrutura diádica composta, formada por núcleo, raiz (complemento do núcleo) e especificador interno (sujeito do verbo na construção intransitiva e objeto na construção transitiva). Acreditamos que os verbos intransitivos alternantes em Dâw estão configurados em uma estrutura como essa. Assim, na construção incoativa, o sujeito do verbo é o especificador interno do predicado. Esse predicado é formado por meio de conflation entre raiz e núcleo verbal. Na construção transitiva (formada pela concatenação de duas estruturas: a diádica composta e a monádica, que está acima daquela), a matriz fonológica do verbo é movida para o núcleo da estrutura monádica. $\mathrm{O}$ especificador interno da estrutura diádica composta permanece in situ, ocupando a posição de objeto da sentença. 
A seguir, apresentamos as estruturas incoativa e transitiva para as sentenças apresentadas em (22).

Alternância causativo-incoativa

a) Yun xop

roupa secar

'A roupa secou'

b) Tir xop yun

3PS secar roupa

'Ele secou a roupa

Estrutura intransitiva

(23)

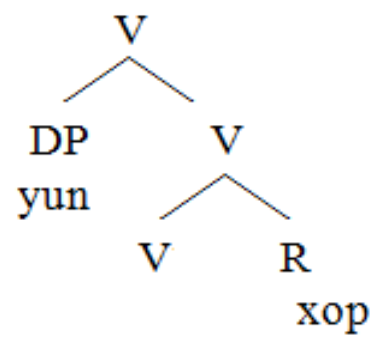

(24) Pós-conflation

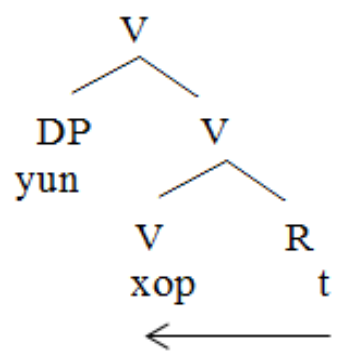

Em (23) apresentamos a estrutura de um verbo intransitivo, no qual a raiz verbal xop 'secar' encontra-se in situ. Em (24), apresentamos uma estrutura na qual a matriz fonológica da raiz xop é transferida via conflation para o núcleo verbal. O sujeito yun 'roupa' é gerado na posição de especificador interno da estrutura diádica acima representada.

\section{Estrutura transitiva}

(25)

Pré-conflation

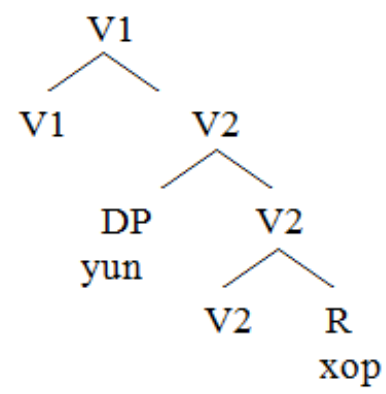

\section{(26) Pós-conflation 1}

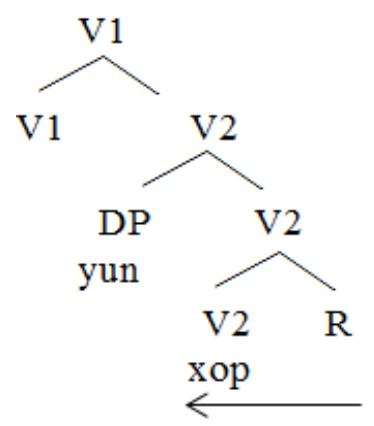


(27)

$$
\text { Pós-conflation } 2
$$

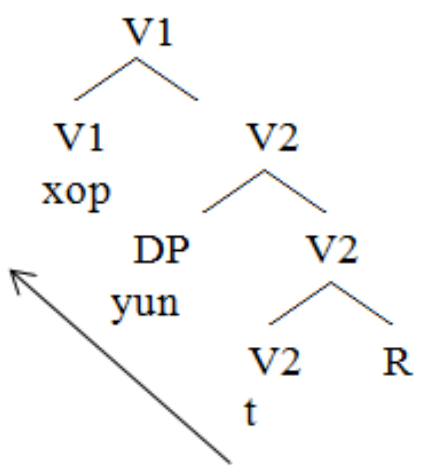

Em (25), apresentamos a raiz xop 'secar' in situ. Em (26), ela é transferida para a posição de núcleo verbal, formando um predicado intransitivo. E por fim, em (27), o predicado verbal é transferido para a posição de núcleo de $\mathrm{V} 1$, estrutura monádica responsável pela transitivização do verbo. O argumento interno yun 'roupa', nessa construção, é objeto do predicado verbal.

Nessas estruturas, o argumento externo é gerado apenas na sintaxe sentencial. Desse modo, o sujeito da construção transitiva, isto é, o argumento externo tir 'ele', não é um argumento interno à configuração projetada pelo item lexical.

\subsubsection{A subclasse dos verbos não-alternantes}

Com relação aos verbos não-alternantes da língua Dâw, achamos três padrões sintático-semânticos importantes para a análise dessa subclasse verbal:

i) Verbos inergativos - Verbos denominais e verbos intransitivos com sujeito agente;

ii) Inacusativos que não alternam - verbos intransitivos não-alternantes com sujeito paciente;

iii) Verbos deadjetivais com semântica estativa;

\section{i) Subclasse dos verbos inergativos}

Os verbos inergativos em Dâw são apresentados na tabela a seguir: 


\begin{tabular}{c|l|l}
\hline Número & \multicolumn{1}{|c|}{ Verbo em Dâw } & \multicolumn{1}{c}{ Tradução } \\
\hline 1 & 'ox & Correr \\
\hline 2 & rôd & Sair \\
\hline 3 & suuk & Caçar \\
\hline 4 & çom & Banhar \\
\hline 5 & win & Trabalhar \\
\hline 6 & rãm xo & Andar \\
\hline 7 & bâay & Arrotar \\
\hline 8 & sux & Esfarelar \\
\hline 9 & 'õot & Chorar \\
\hline 10 & çâk & Pular \\
\hline 11 & roo' & Tossir \\
\hline 12 & 'ô & Rir \\
\hline 13 & âaw & Gritar \\
\hline 14 & yũmrũ & Cantar \\
\hline 15 & yam & Dançar \\
\hline 16 & yok & Nadar \\
\hline 17 & çầ & Saltar \\
\hline 18 & leep & Brilhar \\
\hline 19 & xaam & Vomitar \\
\hline 20 & bax & Suar \\
\hline 21 & baak & Soluçar \\
\hline 22 & ratĩs & Espirrar \\
\hline
\end{tabular}

Tabela 5.3: Verbos intransitivos com sujeito agente e denominais não-alternantes

Prototipicamente, nas línguas mais conhecidas atualmente (vide HALE \& KEYSER 2002, HASPELMATH 1993, entre outros), verbos inergativos como nadar, arrotar, cantar, trabalhar e banhar-se são verbos não-alternantes, à semelhança do que encontramos no Dâw.

Para autores como Hale \& Keyser (2002), esses tipos de predicados verbais são verbos monádicos, isto é, são formados a partir de uma estrutura do tipo monádica. Esses verbos não projetam especificador interno e por isso não podem configurar uma estrutura do tipo alternante, com especificador e complemento.

A agramaticalidade desses tipos de verbos diante desse processo está relacionada ao fato de que verbos monádicos não possuem uma raiz predicadora, isto é, a raiz desses verbos não projeta um especificador interno, como é observado nos verbos diádicos compostos. Uma vez que verbos monádicos não projetam esse tipo de argumento, a transitivização não ocorre, pois não há espaço na estrutura monádica responsável por comportar o objeto de uma construção causativa. Desse modo, mesmo que haja o encaixamento de uma estrutura monádica acima de outra estrutura monádica, a 
configuração formada não é boa, pois ela não possui um núcleo que projeta o argumento interno (objeto na sentença transitiva), elemento importante no processo de transitivização, pois sem ele, a sentença transitiva torna-se agramatical.

A agramaticalidade dessa formação pode ser vista a seguir:

Alternância causativo-incoativa

(28)

a) Woor 'ox

tukano correr

'O tukano correu'

b) ${ }^{*} \mathbf{T i r}$
3PS

Estrutura intransitiva

(29) Pré-conflation<smiles>[R]C([Y])[Y]</smiles>

'ox
(30) Pós-conflarion

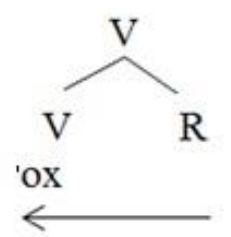

Estrutura transitiva agramatical

Pré-conflation

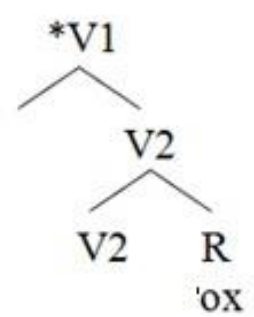

(32) Pós-conflation

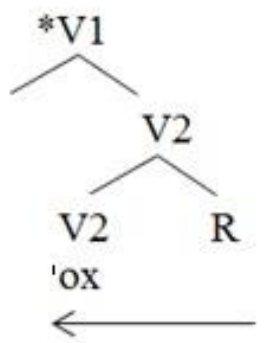

Como podemos ver nas estruturas acima, o encaixamento de outra estrutura monádica acima da estrutura monádica do verbo 'ox 'correr', por exemplo, não transitiviza automaticamente o verbo em questão, pois diferentemente do que vimos na estrutura diádica composta do verbo xop 'secar' (estruturas de (23) a (27)); nas estruturas apresentadas em (31) e (32) com o verbo 'ox não há espaço para a projeção de 
um especificador interno (sujeito do verbo na estrutura intransitiva e objeto do verbo na estrutura transitiva).

No caso dos verbos denominais, cuja estrutura também é a monádica, todas as estruturas e processos sintáticos discutidos acima são preservados, com a diferença de que na classe dos verbos intransitivos não-alternantes, a natureza da raiz é acategorial, e nos verbos denominais, a natureza da raiz é um nome.

Alternância causativo-incoativa

a) Dâw tee 'õot

gente filho chorar

'A criança chorou'

b) *Dâw 'ãy 'õot dâw tee-ũuy'
gente fêmea chorar gente filho-MDO

Estrutura intransitiva

$$
\text { Pré-conflation }
$$<smiles>[R]C([Y])[Y]</smiles>

' $\widetilde{\text { oot }}$
(35) Pós-conflation

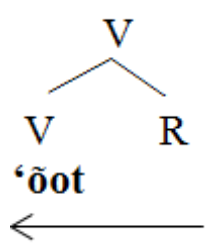

\section{Estrutura transitiva agramatical}

(36)

$$
\text { Pré-conflation }
$$

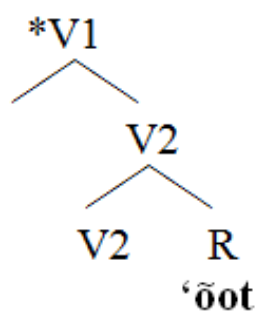

(37) Pós-conflation

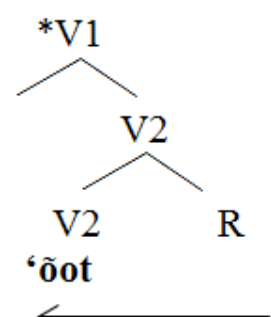

Verbos com estrutura monádica podem ser transitivizados, mas isso ocorre via transitivização complexa, ou causativização, na qual um predicado verbal tem sua valência aumentada por meio da inserção do causativizador dôo 'fazer' ao VP. Nas próximas seções, discutiremos com mais detalhes esse processo de aumento de valência. 
Por fim, os sujeitos de verbos com esse tipo de estrutura geralmente possuem papel temático de agente, uma vez que esses argumentos não são internos, mas são argumentos externos inseridos na sintaxe, após o movimento do núcleo verbal para posições acima de VP.

\section{ii) Subclasse de verbos inacusativos que não alternam}

A seguir, apresentamos a subclasse dos verbos inacusativos não-alternantes:

\begin{tabular}{c|l|l}
\hline Número & \multicolumn{1}{|c|}{ Verbo em Dâw } & \multicolumn{1}{c}{ Tradução } \\
\hline 1 & 'ãa & Dormir \\
\hline 2 & yelêew & Transformar-se \\
\hline 3 & kog'õogn & Desmaiar \\
\hline 4 & çeeb & Mudar \\
\hline 5 & 'ub & Acordar \\
\hline 6 & nõx & Cair \\
\hline 7 & kũm & Afundar \\
\hline 8 & pôw' & Boiar \\
\hline 9 & pêg-saak & Crescer \\
\hline 10 & Kas & Estragar \\
\hline 11 & yum & Melhorar \\
\hline 12 & xaw & Ferver \\
\hline 13 & beg & Clarear \\
\hline 14 & rõ & Queimar \\
\hline 15 & baax & Aparecer \\
\hline & \multicolumn{2}{|l}{ Tabela 5.4: Verbos inacusativos que não alternam } \\
\hline
\end{tabular}

Verbos como rõ 'queimar', pêg-saak 'crescer', nõx 'cair', entre outros possuem um sujeito cujo papel temático é tema ou paciente, isto é, aquele que sofre a ação do predicado verbal (diferentemente dos verbos intransitivos vistos anteriormente, como wĩnh 'trabalhar', 'ox 'correr', entre outros, cujo sujeito tem papel temático de agente).

Dessa forma, esses verbos não podem ser figurados em uma estrutura monádica, pois verbos com esse tipo de estrutura possuem como sujeito argumentos externos, projetados na sintaxe e não na estrutura argumental.

A natureza semântica do sujeito desses verbos aproxima-os da subclasse de verbos alternantes, isto é, inacusativos, formados a partir de uma estrutura argumental diádica composta, cujo sujeito da construção intransitiva é um argumento interno à estrutura. Esses tipos verbais, como já vimos, podem alternar entre uma forma intransitiva e transitiva. Na construção intransitiva, o argumento interno sobe para a 
posição de especificador externo em um núcleo acima de VP e realiza-se como sujeito da construção intransitiva; todo esse processo é realizado na sintaxe. Na construção transitiva, esse argumento permanece in situ, e realiza-se como objeto da construção transitiva. Argumentos internos, portanto, possuem características semânticas de um tema ou paciente, entidade que sofre o efeito de alguma ação. Essa característica semântica é própria de argumentos internos devido à natureza categorial da sua projeção.

Nesse sentido, devido à natureza semântica dos predicados verbais analisados nessa seção, analisamos esses verbos como inacusativos, tipos verbais que projetam um argumento interno.

Todavia, diferentemente de verbos inacusativos formados a partir de uma estrutura diádica composta como wztt 'chegar' e pêt 'quebrar', os verbos inacusativos como nõx 'cair' e baax 'aparecer' não alternam entre uma forma transitiva e intransitiva. Desse modo, os verbos apresentados na tabela 5.4 são analisados como inacusativos não-alternantes, pois apresentam características semânticas de verbos inacusativos, mas não alternam entre uma forma intransitiva e transitiva.

Hale \& Keyser (2002) mostram que em inglês existem verbos inacusativos nãoalternantes como arrive 'chegar', appear 'aparecer' e occur 'ocorrer' que não podem ser transitivizados, como ocorre com verbos inacusativos como break 'quebrar'. Além disso, esses verbos podem participar de construções do tipo there-insertion, como pode ser visto nos exemplos abaixo:

a) Many guests arrived (at the party)

'Muitos convidados chegaram (à festa)'

b) There arrived many guests (at the party)

'Muitos convidados chegaram (à festa)'

c) * John arrived many guests (at the party)

(HALE \& KEYSER, 2002:189)

Para os autores, na sentença (38a), many guests 'muitos convidados' são originados na posição de especificador de uma estrutura do tipo diádica básica que é complemento do verbo arrive, núcleo de uma estrutura do tipo monádica. 
(39)

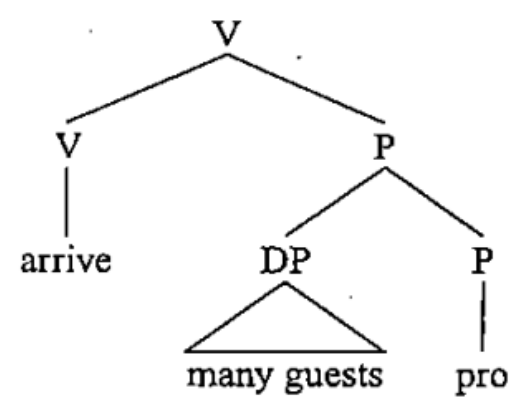

(HALE \& KEYSER, 2002:189)

$\mathrm{O}$ núcleo de $\mathrm{P}$, na construção diádica básica, pode ser preenchido (at (the party)), ou pode ser ocupado por uma preposição abstrata não realizada sintaticamente e representada na estrutura como pro.

Em construções do tipo (38a), many guests sobe para a posição de sujeito na sentença, na posição de especificador de IP, na sintaxe. Alternativamente, o expletivo there pode ser inserido na posição de sujeito da sentença, satisfazendo o princípio de EPP (Extended Projection Principle), princípio que prevê que a posição de sujeito de uma sentença deve estar sempre preenchida, mesmo que por algum núcleo expletivo ou nulo como pro.

Verbos com esse tipo de construção não podem alternar pelo mesmo motivo que verbos monádicos: verbos inacusativos não-alternantes não projetam um argumento interno. A estrutura diádica básica (complemento da estrutura monádica) é uma small clause e gera o argumento interno, mas esse argumento pertence à mini-oração e não ao verbo gerado no núcleo da estrutura monádica. Desse modo, arrive não predica um argumento interno, mas contém um argumento que é predicado por outro núcleo, no caso, P. Assim, esses verbos são estruturalmente verbos monádicos que tomam como complemento uma estrutura diádica básica que 'fornece' o argumento interno ao verbo.

Além disso, verbos desse tipo não podem figurar em uma sentença na qual o argumento externo é inserido na sintaxe, como ocorre com verbos monádicos. Ou seja, verbos inacusativos não-alternantes não predicam argumentos externos na sintaxe, pois verbos como arrive não atribuem caso nominativo ao argumento externo. Isso ocorre, pois o núcleo $\mathrm{P}$ não atribui caso aos seus argumentos, logo, o papel de atribuidor de caso é exercido pelo verbo arrive, que atribui caso ao argumento interno many guests. Desse modo, caso houvesse a inserção de um argumento externo na sintaxe, acima de $\mathrm{VP}$, como ocorre com verbos monádicos, esse argumento não receberia caso, pois o 
verbo já teria saturado sua capacidade de atribuição de caso com o argumento interno gerado por P. É devido a essas propriedades que a sentença (38c) é agramatical.

Dessa forma, analisamos os verbos apresentados nessa seção como verbos inacusativos não-alternantes do tipo arrive 'chegar'. O sujeito do verbo possui papel de paciente ou tema, pois ele é gerado como um argumento interno de uma construção diádica básica. O verbo, núcleo de uma estrutura monádica, toma como complemento a estrutura diádica básica que não projeta fonologicamente uma preposição.

Exemplo:

a) Baa' rõ

beiju queimar

'O beiju queimou'

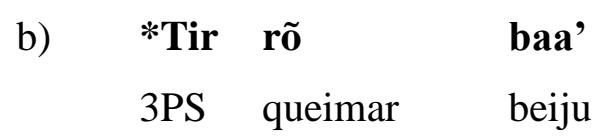

\section{Estrutura intransitiva}

(41)

\section{Pré-movimento}

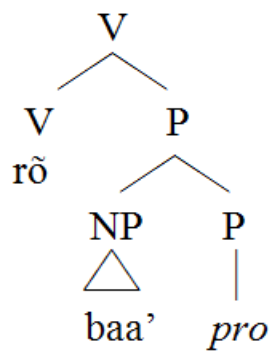

(42) Pós-movimento

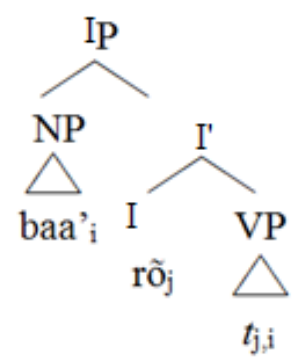

Na sintaxe, o verbo sobe para a posição de núcleo de IP e o argumento interno sobe para a posição de especificador de IP (onde ele é categorizado como sujeito da sentença) (estrutura (42)).

\section{Estrutura transitiva agramatical}

(43)

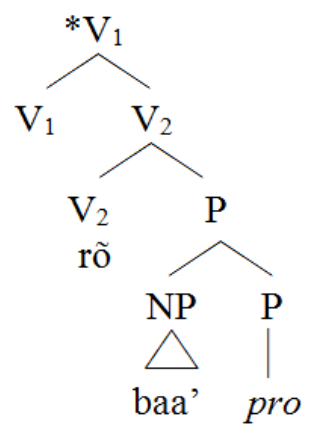




\section{iii) Verbos deadjetivais com semântica estativa}

Na tabela abaixo, apresentamos os verbos 'deadjetivais' em Dâw:

\begin{tabular}{c|l|l}
\hline Número & \multicolumn{1}{|c}{ Verbo em Dâw } & \multicolumn{1}{c}{ Tradução } \\
\hline 1 & xub-sõk rãm & Estar triste \\
\hline 2 & kub rãm & Estar escuro \\
\hline 3 & rân rãm & Estar velho \\
\hline 4 & duy rãm & Estar sujar \\
\hline 5 & mẽn rãm & Ser curto \\
\hline 6 & pêg rãm & Ser grande \\
\hline 7 & ça rãm & Ser preto \\
\hline 8 & lâk rãm & Ser magro \\
\hline 9 & çii rãm & Ser azedo \\
\hline 10 & dep rãm & Ser gordo \\
\hline 11 & tâaw rãm & Estar bravo \\
\hline 12 & kas rãm & Ser feio \\
\hline 13 & muj rãm & Ser úmido \\
\hline 14 & wê rãm & Estar molhado \\
\hline 15 & sêj rãm & Estar cheio \\
\hline 16 & 'wât rãm & Ser comprido \\
\hline
\end{tabular}

Tabela 5.5. Verbos deadjetivais não alternantes

Para Hale \& Keyser (2002), verbos que podem sofrer alternância causativoincoativa são verbos de estrutura diádica composta, cujo núcleo projeta um especificador interno. Este especificador é projetado pelo verbo, mas é semanticamente exigido pela raiz (complemento de V) de natureza adjetival. Dessa forma, verbos derivados de adjetivos possuem esse tipo de estrutura e, consequentemente, são verbos que alternam, ou seja, transitivizam-se automaticamente. Todavia, como pudemos perceber pelos dados desses tipos verbais, em Dâw, os verbos 'deadjetivais' elicitados não se transitivizaram automaticamente. $\mathrm{O}$ aumento de valência ocorreu apenas por meio do processo de causativização, ou seja, por meio da inserção do causativizador dôo 'fazer'.

Acreditamos que essa restrição de alternância se deve à estrutura argumental dos verbos com raiz adjetival em Dâw. Como apresentamos no capítulo 3, os verbos 'deadjetivais' em Dâw não são derivados morfologicamente, mas eles são construções analíticas nas quais o adjetivo não é verbalizado, mas é complemento de uma cópula.

Dessa forma, à luz dos princípios teóricos de Hale \& Keyser (2002), argumentamos que os verbos 'deadjetivais' da língua Dâw possuem uma estrutura 
diádica composta, uma vez que a raiz desses verbos é um adjetivo. O núcleo verbal é preenchido por uma cópula que toma como complemento o adjetivo. Aquele não sofre conflation com seu complemento, pois esse processo só ocorre quando o núcleo verbal é vazio, ou afixal ${ }^{10}$. Caso esse núcleo seja fonologicamente pleno, ou seja, possua uma matriz fonológica, não ocorre conflation.

Dessa forma, assumimos que a agramaticalidade desses verbos diante do processo de transitivização automática ocorre devido à impossibilidade de conflation entre o núcleo verbal (cópula) e a raiz (adjetivo). Exemplo:
(44) a)
weed
çii rãm
comida
azeda ficar

'A comida azedou'
b) *yu' çii
rãm weed
sol azedou
ficar comida

\section{Estrutura intransitiva}

(45)

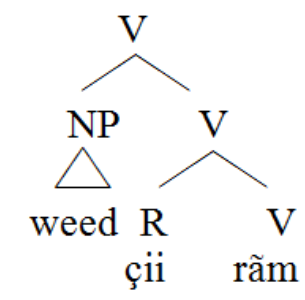

\section{Estrutura transitiva agramatical}

(46) Inserção de uma construção monádica acima da estrutura diádica

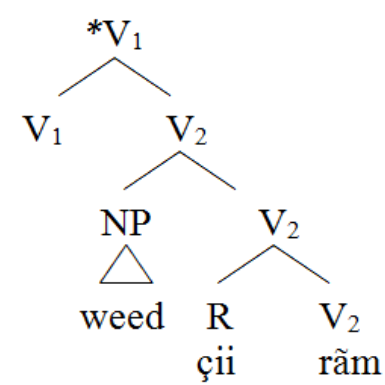

${ }^{10}$ Para Halle \& Kayser (2002), afixos possuem uma característica fonológica 'defeituosa', por isso permitem conflation com a raiz. 


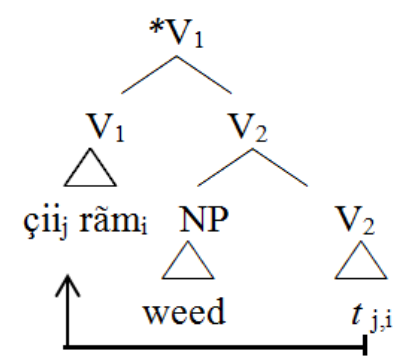

Como já foi discutido, construções causativas são formadas pela concatenação de duas estruturas: a diádica composta e a monádica, concatenada acima daquela. Nesse processo, primeiramente, a matriz fonológica do verbo é movida por conflation da raiz para o núcleo verbal da estrutura diádica, em seguida a matriz fonológica do núcleo é movida para o núcleo verbal da estrutura monádica. Como o predicado deadjetival em Dâw é analítico, não é possível haver conflation entre raiz e núcleos verbais (estrutura (46) e (47)). O especificador interno da estrutura diádica sobe para posições acima de VP para receber caso na sintaxe e se tornar sujeito da sentença.

\subsection{Causativização em Dâw}

A causativização, ou transitivização complexa (HALE \& KEYSER, 2002), diferentemente da transitivização automática é um processo no qual um predicado verbal, independente de sua estrutura argumental, tem sua valência aumentada por meio da inserção de um verbo causativo à sua raiz. Esse verbo ou auxiliar causativo pode se manifestar: i) como um morfema preso ao VP; ii) ou como um verbo leve, que introduz um argumento causa ou agente na sintaxe. Isso é fundamentalmente diferente do que ocorre na transitivização, na qual o especificador já está presente na estrutura argumental.

De acordo com Martins (2004), em Dâw, sentenças causativas são formadas por meio do auxiliar causativo dôo, traduzido como 'fazer'. Esse causativizador precede o verbo principal e adiciona à sentença um argumento sujeito agente. Analisamos as construções formadas por $d \hat{o} o$ como casos de causativização analítica, na qual um verbo causativo aparece no núcleo funcional do sintagma verbal complexo. 
Exemplo:

$(48)$
a) Bee pêt
pau quebrar
'O pau quebrou'

$\begin{array}{lll}\text { b) Tir dôo pêt } & \text { bee-ũuy' } \\ \text { 3PL } & \text { CAUS quebrar } & \text { pau-MDO }\end{array}$

'Ele fez o pau quebrar'

Em Dâw, dôo também é um predicado verbal transitivo traduzido como 'levar'.
Bug tir dôo xâd dâw-ũuy'
então 3PS levar ASPC gente-MDO
'Então ele levou os dâw'

(História do filhote de jabuti, Nazaré (narradora Dâw))

Neste trabalho, testamos o causativizador dôo com dois grupos de verbos: intransitivos (70 verbos) e transitivos (15 verbos), totalizando 85 verbos testados.

\begin{tabular}{|c|c|c|c|}
\hline Número & Verbo em Dâw & Tradução & Classe verbal \\
\hline 1 & wuth & Chegar & Intransitivo \\
\hline 2 & baad & Virar & Intransitivo \\
\hline 3 & 'eed & Virar & Intransitivo \\
\hline 4 & bâar & Derramar & Intransitivo \\
\hline 5 & pêt & Quebrar & Intransitivo \\
\hline 6 & Woox & Quebrar & Intransitivo \\
\hline 7 & xop & Secar & Intransitivo \\
\hline 8 & pô & Abrir & Intransitivo \\
\hline 9 & tobuk & Fechar & Intransitivo \\
\hline 10 & yapilu & Começar & Intransitivo \\
\hline 11 & çêe & Espalhar & Intransitivo \\
\hline 12 & rud & Derreter & Intransitivo \\
\hline 13 & $\mathrm{r} \tilde{\mathrm{u}}$ & Terminar & Intransitivo \\
\hline 14 & wâg & Balançar & Intransitivo \\
\hline 15 & pâd & Rolar & Intransitivo \\
\hline 16 & rã & Parar & Intransitivo \\
\hline 17 & leg & Apagar & Intransitivo \\
\hline 18 & 'ox & Correr & Intransitivo \\
\hline 19 & rôd & Sair & Intransitivo \\
\hline 20 & 'ãa & Dormir & Intransitivo \\
\hline 21 & suuk & Caçar & Intransitivo \\
\hline 22 & yelêew & Transformar-se & Intransitivo \\
\hline 23 & kog'õogn & Desmaiar & Intransitivo \\
\hline 24 & çeeb & Mudar & Intransitivo \\
\hline
\end{tabular}




\begin{tabular}{|c|c|c|c|}
\hline 25 & ' $\mathrm{ub}$ & Acordar & Intransitivo \\
\hline 26 & çom & Banhar & Intransitivo \\
\hline 27 & win & Trabalhar & Intransitivo \\
\hline 28 & nõx & Cair & Intransitivo \\
\hline 29 & kũm & Afundar & Intransitivo \\
\hline 30 & pôw' & Boiar & Intransitivo \\
\hline 31 & pêg-saak & Crescer & Intransitivo \\
\hline 32 & stux & Esfarelar & Intransitivo \\
\hline 33 & 'õot & Chorar & Intransitivo \\
\hline 34 & çâk & Pular & Intransitivo \\
\hline 35 & roo' & Tossir & Intransitivo \\
\hline 36 & 'ô & Rir & Intransitivo \\
\hline 37 & âaw & Gritar & Intransitivo \\
\hline 38 & yũmrũ & Cantar & Intransitivo \\
\hline 39 & yam & Dançar & Intransitivo \\
\hline 40 & yok & Nadar & Intransitivo \\
\hline 41 & çâ & Saltar & Intransitivo \\
\hline 42 & leep & Brilhar & Intransitivo \\
\hline 43 & xaam & Vomitar & Intransitivo \\
\hline 44 & bax & Suar & Intransitivo \\
\hline 45 & bâay & Arrotar & Intransitivo \\
\hline 46 & baak & Soluçar & Intransitivo \\
\hline 47 & ratĩs & Espirrar & Intransitivo \\
\hline 48 & kas & Estragar & Intransitivo \\
\hline 49 & yum & Melhorar & Intransitivo \\
\hline 50 & rãm xo & Andar & Intransitivo \\
\hline 51 & xaw & Ferver & Intransitivo \\
\hline 52 & beg & Clarear & Intransitivo \\
\hline 53 & rõ & Queimar & Intransitivo \\
\hline 54 & baax & Aparecer & Intransitivo \\
\hline 55 & xub-sõk rãm & Estar triste & Intransitivo \\
\hline 56 & kub rãm & Estar escuro & Intransitivo \\
\hline 57 & rân rãm & Estar velho & Intransitivo \\
\hline 58 & duy rãm & Estar sujar & Intransitivo \\
\hline 59 & mẽn rãm & Ser curto & Intransitivo \\
\hline 60 & pêg rãm & Ser grande & Intransitivo \\
\hline 61 & ça rãm & Ser preto & Intransitivo \\
\hline 62 & lâk rãm & Ser magro & Intransitivo \\
\hline 63 & çii rãm & Ser azedo & Intransitivo \\
\hline 64 & dep rãm & Ser gordo & Intransitivo \\
\hline 65 & tâaw rãm & Estar bravo & Intransitivo \\
\hline 66 & kas rãm & Ser feio & Intransitivo \\
\hline 67 & muj rãm & Ser úmido & Intransitivo \\
\hline 68 & wê rãm & Estar molhado & Intransitivo \\
\hline 69 & sêj rãm & Estar cheio & Intransitivo \\
\hline 70 & 'wât rãm & Ser comprido & Intransitivo \\
\hline 71 & rõk & Cortar & Transitivo \\
\hline
\end{tabular}




\begin{tabular}{l|l|l|l}
\hline 72 & kâs & Morder & Transitivo \\
\hline 73 & yũt & Matar & Transitivo \\
\hline 74 & wây & Ver & Transitivo \\
\hline 75 & mũm & Abraçar & Transitivo \\
\hline 76 & çũnh & Beijar & Transitivo \\
\hline 77 & ya' & Assar & Transitivo \\
\hline 78 & xa & Cozinhar & Transitivo \\
\hline 79 & âg & Beber & Transitivo \\
\hline 80 & rê' & Cavar & Transitivo \\
\hline 81 & nee & Fazer & Transitivo \\
\hline 82 & rõoy & Focar & Transitivo \\
\hline 83 & 'ũum & Bater (genérico) & Transitivo \\
\hline 84 & weed & Comer & Transitivo \\
\hline 85 & paar & Saber & Transitivo \\
\hline \multicolumn{2}{c}{ Tabela 5.6: Verbos intransitivos e transitivos testados com dôo }
\end{tabular}

\subsubsection{Causativização com verbos intransitivos}

Com relação à causativização analítica dos verbos intransitivos em Dâw, percebemos que todos os verbos testados puderam ser causativizados por dôo 'fazer', que adiciona um argumento sujeito causa ou agente ao predicado verbal intransitivo. $\mathrm{O}$ sujeito da construção intransitiva, após a causativização, é realizado como objeto. Dependendo do seu traço semântico (definido ou animado), o argumento objeto pode

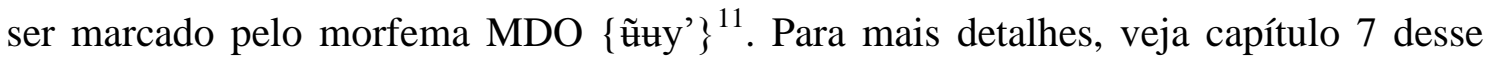
trabalho.

Dessa forma, o uso de dôo não distingue subclasses de verbos intransitivos. Apresentamos os dados obtidos na elicitação dos processos de causativização com os verbos testados. Em (50), dôo co-ocorre com um verbo alternante, ou inacusativo; em (51), dôo co-ocorre com um verbo não-alternante inergativo; em (52), dôo co-ocorre com um verbo inacusativo não-alternante; e, por fim, nos exemplos (53) e (54), dôo coocorre nos contextos de verbos 'deadjetivais'.

$$
\begin{aligned}
& \text { a) Buuy wutd } \\
& \text { homem branco chegar } \\
& \text { 'O homem branco chegou' }
\end{aligned}
$$

\footnotetext{
11 MDO: marca associada aos objetos de sentenças transitivas. É empregada de acordo com traços semânticos do objeto marcado. Esses traços estão relacionados a distinções de referencialidade baseadas em escalas de definitude e animacidade. Analisamos a marca morfológica apresentada nos objetos das sentenças transitivas em Dâw como MDO, devido à restrição semântica dos objetos marcados morfologicamente.
} 
b) Tir dôo wuud buuy-ũuy'

3PS CAUS chegar homem branco-MDO

'Ele fez o homem branco chegar'

$(51)$

a) Woor 'ox

tukano correr

'O tukano correu'

b) Tir dôo 'ox woor-ũuy'

3PL CAUS correr tukano-MDO

'Ele fez o tukano correr'

(52)

a) Yun rõ

roupa queimar

'A roupa queimou'

b) Tir dôo rõ yun

3PS CAUS queimar roupa

'Ele queimou a roupa'

(53)

a) Weed çii rãm

comida azedo ficar

'A comida azedou (Lit.: A comida ficou azeda)'

b) Dâw ãy dôo çii weed

gente fêmea CAUS azedo comida

'A mulher fez a comida azedar (Lit.: A mulher fez azeda a comida)

c) Dâw ãy dôo çii rãm weed

gente fêmea CAUS azedar ficar comida

'A mulher azedou a comida (Lit.: A mulher fez a comida ficar azeda)' 
(54)

a) Dâw xut dep rãm

gente macho gordo ficar

'O homem engordou (Lit.: O homem ficou gordo)'

b) Dâw ãy dôo dep dâw xut-ũuy'

gente fêmea CAUS gordo gente macho-MDO

'A mulher engordou o homem (Lit.: A mulher fez o homem gordo)

c) *Dâw ãy dôo dep rãm dâw xut-ũuy' gente fêmea CAUS gordo ficar gente macho-MDO

Com todas as subclasses de verbos intransitivos testados, o núcleo funcional dôo 'fazer' é concatenado ao verbo na sintaxe. Assim, o causativizador insere um argumento externo ao VP, e não ao núcleo verbal ainda em nível de estrutura argumental, conforme vemos a seguir exemplificado com o verbo intransitivo ' $x x$ 'correr' (sentença apresentada em (51)):

Estrutura causativa de verbos intransitivos

(55)

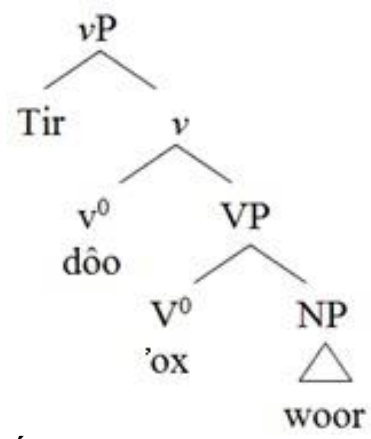

É possível encontrar verbos 'deadjetivais' causativizados, mas nesses casos, a cópula rãm 'ir' está presente. Todavia, essa construção não é aceita por todos os informantes testados, conforme pudemos ver pela agramaticalidade desse tipo de construção apresentada na sentença (54c). No entanto, quando possível, verbos 'deadjetivais' causativizados possuem a seguinte estrutura: 
(56)

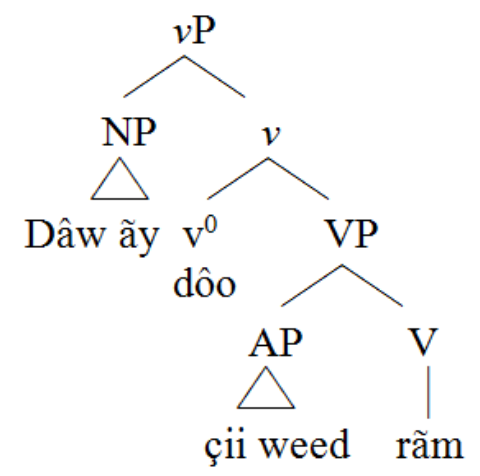

No caso dos verbos 'deadjetivais', é mais usual que a construção causativa apareça sem a cópula rãm 'ir' e o único predicado verbal presente na sentença seja dôo 'fazer', que ocupa o núcleo de $v$ (vezinho), e toma como complemento o sintagma adjetival realizado, nesses casos, como uma mini-oração (small-clause). Apresentamos a estrutura referente à sentença $(53 b)$ :

\section{Estrutura causativa}

(57)

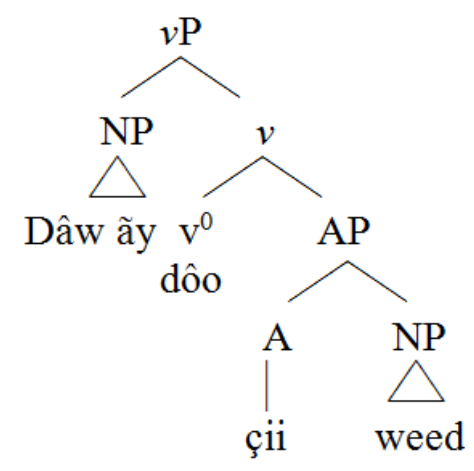

\subsubsection{Causativização com verbos transitivos}

Com relação à causativização com predicados verbais transitivos, todos os verbos testados puderam ser causativizados por dôo. $\mathrm{O}$ causativizador adiciona ao predicado verbal um argumento sujeito, agente ou causa, à sentença. O sujeito da construção transitiva, na sentença causativizada, realiza-se como objeto, que é sufixado por $\{-\tilde{u} u y$ ' $\}$, tendo em vista seus traços semânticos, isto é, [+animado] e [+definido].

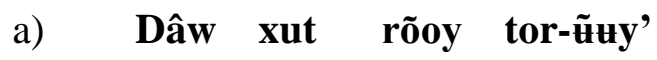
gente macho focar porco-MDO
'O homem focou o porco' 
b) Dâw 'ãy dôo rõoy dâw xut-ũuy' tor-ũuy' gente fêmea CAUS focar gente macho-MDO porco-MDO 'A mulher fez o homem focar o porco'

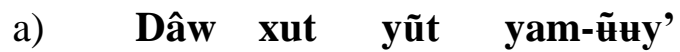

gente macho matou cachorro-MDO

'O homem matou o cachorro'

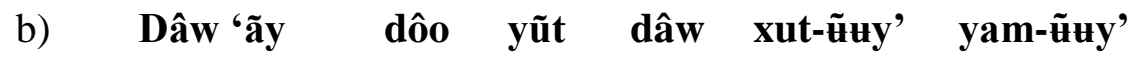
gente fêmea CAUS matar gente macho-MDO cachorro-MDO 'A mulher fez o homem matar o cachorro'

Esse resultado nos mostra que o uso do causativizador dôo em Dâw não possui restrições quanto à valência do verbo. Tanto com predicados verbais intransitivos quanto transitivos, dôo acrescenta ao verbo um argumento sujeito agente ou causa.

\subsection{Síntese do capítulo}

Nesse capítulo, analisamos o processo de transitivização e causativização em Dâw. Com relação ao processo de transitivização, demonstramos que as restrições de alternância de alguns verbos intransitivos se devem à estrutura argumental de cada tipo verbal. No caso dos verbos intransitivos alternantes ou inacusativos, observamos que eles são formados a partir de estrutura diádica composta, que projeta um especificador interno e um complemento, o que lhes permite alternar entre uma forma intransitiva e transitiva. No caso dos verbos denominais e inergativos, percebemos que eles são formados a partir de uma estrutura argumental monádica, que não projeta especificador interno, o que impede a alternância. Verbos inacusativos não-alternantes são formados a partir de uma estrutura monádica que toma como complemento uma estrutura diádica básica, que projeta um argumento interno. Verbos desse tipo não alternam, pois eles não são formados por uma estrutura diádica, mas contêm uma estrutura desse tipo. Com relação aos verbos 'deadjetivais', vimos que eles são formados a partir de uma cópula que toma como complemento um adjetivo. Dessa forma, uma vez que raiz e núcleo 
verbal possuem conteúdo fonológico pleno (não vazio), não é possível fazer conflation entre núcleo e raiz, o que impede que o predicado verbal seja formado. Essa estrutura explica a agramaticalidade desses verbos frente ao processo de transitivização automática.

Com relação à causativização, ou transitivização complexa, vimos que há, em Dâw, um causativizador, isto é, dôo 'fazer', que adiciona ao predicado verbal, tanto intransitivo quanto transitivo, um argumento externo. Desse modo, não há restrições de valência verbal quanto à causativização com esse auxiliar. 


\section{Capítulo 6: Processos de redução de valência}

\subsection{Introdução}

Neste capítulo, discutiremos quatro processos de intransitivização: construção de sentenças incoativas (ou anticausativas), a partir de sentenças transitivas; formação de voz média, reflexiva e passiva em Dâw.

Segundo Martins (2004), construções incoativas e médias são formadas por meio do apagamento do tom lexical do verbo transitivo. Construções passivas, por sua vez, são formadas por meio do acréscimo de tom ascendente no predicado verbal. Por fim, as reflexivas seriam derivadas a partir do morfema reflexivo xup. Os dados de elicitação realizados nessa pesquisa contrariaram as hipóteses de Martins (2004) e revelaram que não há morfologia tonal para a formação de sentenças incoativas, médias e passivas em Dâw. Sentenças incoativas e médias não possuem morfologia específica (ou são formadas a partir de morfema zero). Não há passivas em Dâw, isto é, os falantes não categorizam esse tipo de eventualidade na língua, e as sentenças reflexivas são formadas por meio de pronomes reflexivos e não propriamente por meio da partícula xup, que, em nossos dados, caracterizou-se como um adjetivo cujo significado é 'mesmo'.

Na seção 6.1, apresentamos a descrição e análise de Martins (2004) acerca da formação de construções incoativas, médias, reflexivas e passivas. Na seção 6.2, apresentamos um panorama teórico acerca das construções incoativas médias, reflexivas e passivas. Na seção 6.3, apresentamos os dados coletados nessa pesquisa e a nossa análise acerca desses quatro processos em questão. Na seção 6.4, apresentamos uma síntese do que foi exposto no capítulo.

\subsection{Os processos de redução de valência descritos por Martins (2004)}

\subsubsection{A formação de verbos intransitivos e médios em Dâw}

Martins (2004) afirma que verbos transitivos podem ser intransitivizados por meio do apagamento do seu tom lexical. Nesse processo, o verbo transitivo, analisado como forma básica por Martins (2004), possui tom e projeta dois argumentos - um 
sujeito e um objeto. $\mathrm{O}$ verbo intransitivo derivado, que projeta um único argumento, não possui tom. Assim, verbos tonais transitivos, quando derivam verbos intransitivos, perdem seu tom lexical. Por esse comportamento, Martins (2004) conclui que o processo de intransitivização decorre do apagamento do tom do verbo transitivo. A seguir, transcrevemos os exemplos extraídos de Martins (2004) ${ }^{1}$.

(1)
a) 'ãr lood
dâr mũunh
1SG descascar PONT 1SG.OBL

'Eu me descasquei'

$\begin{array}{lllll}\text { b) ‘ãr } & \text { lod } & \text { rãm } & \text { yu' } & \text { xad } \\ \text { 1SG } & \text { descascar:INTRV } & \text { ir } & \text { estar quente } & \text { por causa de }\end{array}$

'Eu me descasquei por causa do sol'

(MARTINS, 2004:674)

(2)
a) 'ãr ceep
1SG arrebentar Mov cipó
doo' yum
'Eu arrebentei o cipó'
b) Yum cep xâd
cipó arrebentar:INTRV DUR
'O cipó arrebentou'

(MARTINS, 2004:674)

Segundo Martins (2004), um verbo transitivo atonal, quando intransitivizado, permanece sem tom e projeta apenas um argumento. Nesse caso, a supressão do argumento sujeito da construção transitiva é a indicação de que houve redução de valência no verbo. A seguir, exemplificamos esse caso.

(3)

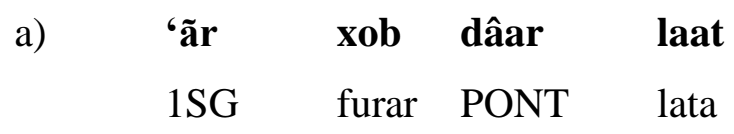

' $\mathrm{Eu}$ furei a lata'

\footnotetext{
${ }^{1}$ Lembramos o leitor que, na ortografia Dâw, o tom é marcado com a duplicação da vogal sobre a qual ele recai. Para mais detalhes, veja seção 1.1.3, do capítulo 1 .
} 


\section{b) laat xob xâd \\ lata furar:INTRV DUR}

'A lata furou'

(MARTINS, 2004:673)

Segundo a autora, o apagamento de tom (ou o tom zero) dos predicados verbais formaria também construções médias. Nesse tipo de construção, o evento verbal ocorreria sem a intervenção de um sujeito agente, pois tal evento se dá de modo natural (espontaneamente), sem uma causa externa. Para a autora, os verbos incoativos (anticausativos) e médios derivados pelo apagamento do tom lexical de verbos transitivos formam uma única classe (classe dos verbos médios, que se opõe à classe dos verbos ativos). Segundo Martins (2004), eles não se distinguem semanticamente, pois ambos expressam um evento espontâneo e tomam um único argumento.

\subsubsection{Voz reflexiva}

Segundo Martins (2004), em Dâw, haveria um morfema reflexivo - a saber, хир - que indica que o objeto possui referência idêntica ao sujeito. Segundo a autora, esse morfema pode ocorrer após o sujeito (exemplo 4), ou após o objeto (exemplo 5):

(4)

$$
\begin{aligned}
& \text { Ãr xup xop dâr } \\
& \text { 1PS REFLX secar PONT }
\end{aligned}
$$

'Eu mesmo me sequei'

(MARTINS: 2004, 379)

\section{Ãr çom ãr xup \\ 1PS banhar 1PS REFLX}

'Eu banho a mim mesmo'

(MARTINS: 2004, 379)

A autora afirma que xup também deriva construções reflexivas enfáticas, nas quais o pronome reflexivo aparece após o sujeito e o objeto aparece na sua forma pronominal oblíqua, como podemos ver nos exemplos abaixo (mũthh, pronome de primeira pessoa do singular, exemplo 6, ou tirũuy', pronome de terceira pessoa do singular, exemplo 7): 
(6) $\tilde{A} \mathbf{r}$ xup ãr tees mũnh

1PS secar 1PS cortar 1PSOBL

'Eu me corto (Lit. Eu mesmo me corto)'

(MARTINS: 2004, 379)

(7)

\begin{tabular}{|c|c|c|c|}
\hline xup-ẽn' & tir-zutuy' & yũt & yed \\
\hline REFLX-REF & 3PS-AFET & matar & INTSI \\
\hline
\end{tabular}

(MARTINS: 2004, 379)

Para Martins (2004), o morfema reflexivo xup indica a noção de algo que é próprio ou característico de alguém, além de também indicar formalmente estruturas enfáticas.

\subsubsection{Voz passiva}

De acordo com Martins (2004), a passiva em Dâw é formada por meio do morfema tonal ascendente e ocorre apenas com verbos transitivos. Para a autora, quando o verbo transitivo com tom ascendente for passivizado, o tom do predicado verbal é preservado e a indicação do processo de passivização ocorre por meio da relação semântica e sintática do verbo com seus agentes. Se o verbo transitivo possuir tom descendente ou for atonal, ele passa a ser realizado com tom ascendente, devido ao processo de passivização.

Segundo a autora, as construções passivas em Dâw não podem ocorrer com o agente da passiva.

Exemplos:

a)

bõrõ ya' yed rãap-ũuy'
fogo assar INTS1 peixe-AFET
'O fogo assou o peixe'
rãap yaa'
peixe assar:APAS
'O peixe foi assado'

(MARTINS, 2004:88) 
Para Martins (2004), a construção passiva possui a mesma leitura que um sintagma nominal. Assim, construções como a apresentada em (8b) também podem ter uma leitura como 'peixe assado'.

Como vimos no capítulo 4, o sistema tonal em Dâw é previsível e não há morfemas tonais que participam de processos gramaticais como a transitivização, por exemplo. Como veremos adiante, os dados coletados acerca desse processo gramatical mostram que não há morfologia específica de passivização nem construções passivas em Dâw.

\subsection{Definindo os processos de intransitivização}

Segundo Kemmer (1994), a voz média é usada para expressar eventos nos quais o sujeito é afetado pela ação verbal. Em uma perspectiva funcional, para a autora, as médias podem ser situadas como categorias intermediárias em uma escala de transitividade ou de elaboração de eventos. Nessa escala, encontram-se, em um polo eventos altamente elaborados, isto é, transitivos, que categorizam a participação de dois (ou mais) participantes de um evento. No outro polo, encontram-se eventos de baixa elaboração, isto é, intransitivos, que categorizam a presença de um único participante do evento.

A voz média e as sentenças reflexivas são categorias intermediárias nessa escala. Nos eventos reflexivos, observa-se a presença de dois participantes correferenciais ou co-indexados, diferentemente de eventos transitivos, nos quais os dois participantes do evento possuem referentes distintos e não estão associados. O sujeito de um verbo reflexivo é o desencadeador [+animado] do evento verbal e também é a entidade afetada por ele. Assim, em eventos como 'John saw himself in the mirror', John é o agente da ação de ver e o objeto afetado por ele, ou seja, o que é visto.

Nos eventos médios, apenas um participante é identificado. As propriedades semânticas desse participante não se distinguem. Não é possível delimitar a ação do sujeito e a afetação do objeto, pois, nesse quadro, o sujeito é afetado pela ação do verbo. É devido a essas propriedades que o verbo de domínio médio possui propriedades formais de intransitividade.

De acordo com Kemmer (1993, 1994), as línguas que marcam morfologicamente a voz média possuem um sistema médio (middle system). O grego - 
trépe-sthai ${ }^{2}$ 'virar-se' - e o alemão - sich verbeugen 'curvar-se' são exemplos de línguas com esse tipo de sistema. Outras línguas, todavia, não apresentam uma morfologia específica para designar a forma média. No inglês, por exemplo, situações de domínio médio são representadas por meio da morfossintaxe intransitiva (wash 'lavar-se' é um verbo intransitivo e de domínio médio) ou por construções compostas (dress/get dressed).

Em línguas como o russo (língua com sistema médio), essa distinção é importante, pois verbos anticausativos e médios apresentam algumas restrições sintáticas que são compartilhadas pelos dois tipos de verbos, o que evidencia que eles pertencem a classes distintas. Segundo Reinhart \& Siloni (2005) apud Lazzarini Cyrino (manuscrito), nas construções de negação do russo, os verbos espontâneos podem apresentar sujeito no caso genitivo, enquanto que verbos de domínio médio não podem.

Exemplo:

a)

$$
\mathrm{Ne}
$$$$
\text { pojavilo-s' }
$$

não

compareceram-se

student-ov

'Os alunos não compareceram'

alunos-GEN

$$
\text { 'Os alunos não compareceram' }
$$

b)

$$
\begin{aligned}
& \text { *Ne } \quad \text { pomylo-s' } \\
& \text { não } \quad \text { lavaram-se } \\
& \text { 'Os alunont-ov }
\end{aligned}
$$

(REINHART \& SILONI 2005 apud LAZZARINI CYRINO (manuscrito):10)

Para Kemmer (1993, 1994), a intransitividade é naturalmente associada às marcas de voz média devido à aproximação semântica entre os tipos situacionais dos eventos médios e intransitivos. Desse modo, ambos os eventos são pouco elaborados, ou seja, possuem baixa transitividade. Todavia, apesar da aproximação entre os dois tipos de evento, a correlação entre as duas construções não é estrita, podendo, inclusive, em algumas línguas, verbos médios serem transitivos ${ }^{3}$.

Para a autora, a voz média é empregada em alguns tipos situacionais específicos, como:

\footnotetext{
${ }^{2}$ Os morfemas de voz média estão em negrito.

${ }^{3}$ Kemmer (1994:186) exemplifica esse fato com as seguintes línguas: islandês: undra-st 'admirar' e ótta$s t$ 'temer'. Latim: vereo-r 'temer'. Húngaro: üt-köz 'chocar-se'.
} 
i) Cuidados com o corpo: vestir-se, lavar-se;

ii) Movimento sem deslocamento: virar-se, esticar-se;

iii) Mudança postural: levantar-se, deitar-se, sentar-se;

iv) Movimento translacional: ir, voar;

v) Eventos naturalmente recíprocos: falar-se, abraçar-se;

vi) Médias Indiretas: adquirir, pedir;

vii) Médias Emocionais: amedrontar-se, enraivecer-se;

viii) Ações de fala emotivas: reclamar, lamentar-se;

ix) Médias cognitivas: acreditar, refletir;

x) Eventos espontâneos: brotar, desaparecer.

(KEMMER, 1993:182-183)

Maldonado (2006), sob a perspectiva da Gramática Cognitiva, também assume que há um contínuo de transitividade, no qual há um polo transitivo (eventos de dois participantes) e um polo intransitivo (eventos de um participante), assim como visto em Kemmer (1994). Para o autor, reflexivas e médias são derivadas de construções transitivas. Todavia, enquanto estas se alinham a construções intransitivas, aquelas se alinham a construções transitivas. Ou seja, nas sentenças reflexivas, agente e paciente podem ser distinguidos, isto é, há uma clara distinção entre os participantes do evento verbal. Já na média não há divisão ou distinção clara entre sujeito e objeto do evento verbal, o que a aproxima de eventos de um único participante.

Dessa forma, para o autor, apesar de ambas as estruturas compartilharem a mesma propriedade - remetem ao sujeito da oração -, há importantes diferenças entre elas, a saber: a reflexiva constrói uma ação na qual agente e paciente são correferenciais e coexistem no evento, como na sentença em russo On utomil sebja 'Ele cansou ele mesmo'. Já as médias remetem ações ou estados que envolvem somente o sujeito: $O n$ utomil-sja 'Ele se cansou'.

Ainda segundo o autor, essa aproximação entre as construções pode ser verificada na forma como algumas línguas categorizam seus verbos médios e intransitivos. Por exemplo, as formas equivalentes do verbo intransitivo em inglês wash 'lavar-se' são verbos de domínio médio em línguas como o Português (lavar-se) e Espanhol (lavar-se).

Para o autor, em línguas que possuem um contraste intransitivo-médio, a construção média designa uma especificação semântica não presente na construção intransitiva. Em espanhol, por exemplo, essa distinção decorre de um contraste 
aspectual com verbos de movimento. Assim, em (10a), a construção intransitiva descreve uma longa cena imperfectiva, já a construção média (10b) descreve uma mudança abrupta de posição.

(10) a. Valeria subió el Popocatepetl in dos días

'Valeria subiu o Popocatepetl em dois dias'

\section{b. Al ver al ratón Valeria se subió a la mesa de un salto}

'Ao ver o rato, Valéria subiu na mesa de repente'

(MALDONADO, 2007: 854)

Para Maldonado (2007), a principal função da média é enfatizar a mudança de estado sofrida pelo sujeito. Eventos espontâneos, que descrevem o momento exato da mudança de estado (exemplo (10b)), são as construções médias esperadas. A seguir, encontramos outro exemplo no qual o evento possui duas leituras: mudança de estado abrupta e evento inesperado.

(11) a) El humo desapareció poco a poco

'A fumaça desapareceu aos poucos'

b) El fantasma se desapareció de pronto

'O fantasma desapareceu de repente'

(MALDONADO, 2007: 857)

Com relação às construções incoativas (ou anticausativas), elas correspondem a construções intransitivas formadas por meio de estratégias de redução de valência, na qual o sujeito do verbo intransitivo derivado corresponde ao objeto da construção transitiva básica. Nesses tipos de sentenças, o sujeito do verbo transitivo não está presente na sentença, o que evidencia um processo claro de redução de valência verbal.

Para Dixon \& Aikhenvald (2000), esse processo de redução de valência é o inverso do encontrado nas construções causativas. Dessa propriedade derivou-se a denominação 'anticausativa'. Verbos anticausativos caracterizam-se por denotarem eventos espontâneos, sem a marca ou presença de agente ou causa.

Verbos incoativos ou anticausativos possuem um sujeito afetado pela ação verbal. Além disso, o evento verbal é entendido como espontâneo, sem um agente ou causa externa. Esses verbos são distintos dos verbos intransitivos ativos, como 'correr' e 'dançar', por exemplo, que possuem um sujeito agente com volição sobre a ação verbal.

Quanto à construção passiva, de modo geral, suas propriedades essenciais são definidas, em termos estruturais, como a demoção de um argumento agente (sujeito) e a 
promoção do argumento objeto paciente para a posição de sujeito de um predicado verbal (cf. CHOMSKY 1981, SHIBATANI 1985, JAEGGLI 1986, entre outros).

Abaixo, apresentamos uma construção passiva considerada padrão pela literatura (cf., KEENAN \& DRYER, 2007):
a) Mary slapped John
b) John was slapped

(KEENAN \& DRYER, 2007:325)

Segundo Keenan \& Dryer (2007), a estrutura apresentada em (12b) é considerada uma construção passiva padrão, pois apresenta as seguintes características:

i. $\quad$ agente da sentença não está presente;

ii. O verbo da construção ativa é transitivo;

iii. O verbo principal expressa uma ação, logo toma como argumentos um sujeito agente e um objeto paciente.

Guardadas as devidas ressalvas quanto à análise e orientação teórica dos autores supracitados, é notório que a passiva apresenta algumas semelhanças estruturais com a construção incoativa, como a redução de valência e a promoção do objeto a sujeito da construção passiva. Desse modo, consideramos a passiva uma construção sintaticamente intransitiva.

Inclusive, muitas línguas possuem a mesma morfologia para marcar construções incoativas e passivas, além de reflexivas, como vemos nos exemplos extraídos do grego (exemplo 13) e do albanês (exemplo 14) apresentados abaixo:

(13) a) I Maria xtenizete

(reflexivo)

'A Maria se penteia"

b) I porta tsakizete

(anticausativo)

'A porta está quebrando'

c) To vivlío dhiavazete apo to koristi

(passivo)

"O livro está sendo lido pela menina"

(LAZZARINI CYRINO, (manuscrito): 02)

(14) a) Femija lahet

(reflexivo)

"A criança se lava"

b) Dera hapet

(anticausativo)

"A porta está se abrindo"

c) Fati parathet nga qeveria

(passivo) 
"O destino é previsto pelo governo"

(LAZZARINI CYRINO, (manuscrito): 02)

Lazzarini Cyrino (manuscrito) chama esse fenômeno de Sincretismo passivoreflexivo (SPR), o qual, segundo o autor, refere-se ao compartilhamento da mesma marca morfológica entre construções reflexivas, verbos anticausativos e passivos. Para o autor, o contexto de ocorrência do fenômeno do SPR pode variar entre as línguas. Algumas línguas, como as citadas acima, utilizam a mesma morfologia para marcar reflexivas, aticausativas e passivas, já outras, como o português e o francês, usam o mesmo morfema para marcar sentenças incoativas e reflexivas (clítico se), mas não passivas.

Exemplos:

(15) Português
a) A criança se lava.
(reflexivo)
b) A porta se abre.
(anticausativo)
c) *A máquina se constrói pelo operário.
(*passiva)

(LAZZARINI CYRINO, (manuscrito): 02)

(16) Francês

a) Judas s'est tué.

(reflexivo)

"Judas suicidou-se"

b) La porte s'est ouverte.

(anticausativo)

"A porta (se) abriu"

c) *Le restaurant s'est lave pour les garçons. (*passivo)

(LAZZARINI CYRINO, (manuscrito): 02)

Mas ainda há línguas cujo morfema de construções incoativas também marca passivas, mas não reflexivas, como vemos nos exemplos, abaixo citados, das línguas Tzutujil (exemplo 17), Evenki (exemplo 18) e Suaili (exemplo 19), extraídos de Haspelmath (1987).

(17)
a) jiq' / ji-j-q'-ik 'afogar-se (tr.) / afogar-se (intr.)'
b) ch'ey / ch'e-j-y-ik 'bater / ser batido'

(DAYLEY 1985 apud HASPELMATH 1987:30)

(18)
a) sokor- / sokor-iv-
'perder / perder-se'
b) tyre- / tyre-v-
'pressionar para baixo/ser
pressionado para baixo) 
(HASPELMATH 1987:30)

(19)
a) vunj- / vunj-ik-
'quebrar (tr.) / quebrar (intr..)
b) it- / it-ik-
'chamar / ser chamado'

(HASPELMATH 1987:30)

Haspelmath (1987) aponta que, apesar da aproximação entre as duas estruturas, há diferenciações importantes entre construções incoativas e passivas: na passiva, o agente é demovido (não está na posição de sujeito), mas pode ser expresso por uma by phase, o que torna a existência do agente implícito, semanticamente, mas não sintaticamente, como podemos ver nas passivas do português, com o emprego da preposição pelo que acompanha o agente da passiva, por exemplo: 'João' em 'O bolo foi cortado (pelo João)'. Na incoativa, o agente é completamente eliminado, não só sintaticamente, mas semanticamente, pois o evento, semanticamente, é tido como espontâneo. Logo, a diferença fundamental entre sentenças incoativas e passivas encontra-se no fato de que, nestas, o argumento agente pode ser omitido, ou seja, sua presença é facultativa, enquanto que, naquelas, o argumento agente é demovido completamente e está ausente sintática e semanticamente. Diante desse fato é que consideramos que as passivas são sintaticamente intransitivas, mas semanticamente transitivas.

Apesar dessa relação estreita entre as construções supracitadas, é necessário apontar, como faz Keenan \& Dryer (2007), que existem línguas que de fato não possuem passivas. Nessas línguas, outras construções que se assemelham às passivas (mas não são consideradas como tal) são produzidas no lugar destas. Segundo os autores, essas construções podem ser:

i. Médias;

ii. Construções com o sujeito subespecificado;

iii. Inversas:

iv. Antipassivas.

Para Keenan \& Dryer (2007), o que diferencia essas construções das passivas é o fato de que, nestas, o sujeito da construção ativa (correspondente à passiva) é expresso por um elemento que não é nem objeto e nem sujeito da construção passiva; e mesmo que ele não esteja expresso, sua existência permanece implícita na construção passiva. Nas construções supracitadas, por sua vez, isso não ocorre. 


\subsection{Reanalisando os processo de intransitivização em Dâw}

Nessa seção, apresentaremos os resultados da coleta de dados acerca dos processos de intransitivação supracitados em Dâw. A discussão sobre a metodologia utilizada em trabalho de campo para a elicitação dos dados discutidos nesse capítulo encontra-se no capítulo 2 do presente trabalho ${ }^{4}$.

A seguir, apresentamos uma tabela com os quinze verbos transitivos testados.

\begin{tabular}{c|l|l}
\hline Número & \multicolumn{1}{|c|}{ Verbo em dâw } & \multicolumn{1}{c}{ Tradução } \\
\hline 1 & Rõk & Cortar \\
\hline 2 & Kâs & Morder \\
\hline 3 & Yũt & Matar \\
\hline 4 & Wây & Ver \\
\hline 5 & Mũm & Abraçar \\
\hline 6 & Çũnh & Beijar \\
\hline 7 & Ya' & Assar \\
\hline 8 & Xa & Cozinhar \\
\hline 9 & Âg & Beber \\
\hline 10 & Rế & Cavar \\
\hline 11 & Nee & Fazer \\
\hline 12 & Rõoy & Focar \\
\hline 13 & 'ũum & Bater (genérico) \\
\hline 14 & Weed & Comer \\
\hline 15 & Paar & Saber \\
\hline & &
\end{tabular}

Todos os dados coletados de construções reflexivas, médias, passivas e incoativas, assim como todo o protocolo de elicitação, encontram-se no Anexo 2 do presente trabalho.

\footnotetext{
${ }^{4}$ Capítulo 2, seção 2.2.2.
} 


\subsubsection{Construções reflexivas}

Em Dâw, a voz reflexiva não possui morfologia verbal específica. Como vimos na seção 6.2, muitas línguas apresentam um afixo verbal que muda a voz ativa de uma sentença para a voz reflexiva. A elicitação dos dados mostrou-nos, por outro lado, que apesar de não possuir reflexivas verbais, Dâw possui reflexivas pronominais, isto é, a leitura reflexiva é dada por meio do uso de um pronome reflexivo na posição de objeto da sentença. Este objeto, para ser um pronome reflexivo, apresenta-se na sua forma oblíqua, como podemos ver no exemplo a seguir.
a) Ãr wâay mũnh
1PS ver 1PS.OBL
'Eu me vi'

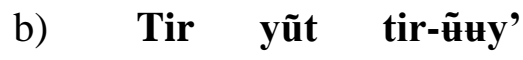
3PS matar 3PS-MDO
'Ele se matou '

Contrariando a hipótese de Martins (2004), não analisamos o morfema xup como um morfema reflexivo nesse trabalho. Os resultados da nossa elicitação de dados mostraram que essa partícula é um adjetivo que significa 'mesmo', 'próprio'. Ela ocorre no domínio do NP (isto é, com o sujeito da sentença) e seu uso indica que o sujeito é único participante do evento verbal. Essa partícula não pode ocorrer com VPs (exemplo 21), mas apenas com sujeitos de sentenças transitivas (exemplo 22) e intransitivas (exemplo 23).

Exemplos:

$\begin{array}{lll}\text { *Buuy } & \text { kâs } & \text { xup } \\ \text { homem branco } & \text { morder } & \text { mesmo }\end{array}$

(22) Ãr xup rôd

1PS mesmosair

'Eu mesmo sai'

$\begin{array}{lll}\tilde{\text { Ar }} \quad \text { xup } & \text { âg } \\ \text { 1PS mesmo } & \text { beber } \\ \text { 'Eu mesmo bebi' } & \end{array}$


Xup 'mesmo' também pode coocorrer na mesma sentença com o pronome reflexivo.

$\begin{array}{llll}\tilde{\mathbf{A r}} & \text { xup } & \text { rõk } & \text { mũnh } \\ 1 \mathrm{PS} & \text { mesmo } & \text { cortar } & \text { 1PS.OBL }\end{array}$

'Eu mesmo me corto'

Acreditamos que as sentenças formadas com xup são sentenças com leitura enfática, em concordância com Martins (2004). O uso dessa partícula denota um evento que é próprio do sujeito, e não de outro indivíduo, enfatizando, dessa forma, uma propriedade do sujeito do predicado.

Os dados elicitados mostram que a voz reflexiva em Dâw exige a presença de dois argumentos correferenciais, isto é, o sujeito e o objeto. Acreditamos que seu uso esteja restrito a predicados transitivos que possuem ambos os argumentos. Nesse sentido, os dados do Dâw vão ao encontro do que foi discutido por Kemmer (1993, 1994) e Maldonado (2006, 2007), os quais afirmam que construções reflexivas codificam eventos transitivos, pois apresentam dois participantes do evento verbal. Todavia, esses dois participantes possuem a mesma referência, isto é, estão coindexados, diferentemente de eventos transitivos prototípicos, que codificam dois participantes distintos.

\subsubsection{Construções médias e incoativas (anticausativas)}

Como foi discutido no capítulo 4, discordamos de Martins (2004) quanto à existência de morfemas tonais na língua em estudo. Pudemos constatar pelos testes realizados que o sistema tonal em Dâw é previsível e a mudança de tom dos predicados verbais obedece a um padrão fonológico organizado em frases fonológicas.

Quanto à existência de outro tipo de morfologia média ou incoativa, a elicitação de predicados verbais nesses tipos de construções nos mostrou que Dâw não apresenta morfologia específica para a formação de voz média e nem de sentenças incoativas.

Quando geradas, construções incoativas (exemplo 25b e 26b) e médias (exemplos 25c e 26c) possuem a seguinte estrutura:
a) Dâw xut rõk tor-ũuy'
gente macho cortar porco-MDO
'O homem cortou o porco 
b) Tor rõk yũtam

Porco cortar ASPC

O porco já cortou’

c) Tor rõk xet

porco cortar rápido

'Porco corta rápido'

(26)

a) Dâw xut ya' tor-ũuy'

gente macho assar porco-MDO

'O homem assou o porco

b) Tor ya' yũtam

Porco assar ASPC

'O porco já assou'

c) Tor dep ya' xet

porco carne assar rápido

'Carne de porco assa rápido'

A construção incoativa sempre é apresentada com a marca aspectual yũtam, que codifica eventos acabados e pontuais. Essa marca aspectual é a junção de dois morfemas de aspecto na língua: yũt 'perfectivo 1' e $\{-\tilde{a} m\}$ 'télico'. A marcação do aspecto nos indica que o evento codificado pelo predicado verbal é, de fato, sem duração e acabado. $\mathrm{O}$ argumento do verbo é afetado por um evento que ocorre espontaneamente.

A construção média veio acompanhada pelo advérbio xet 'rápido' (exemplos 25c e 26c) ou wâsoer 'fácil' (exemplo 27b). A ocorrência desses advérbios nesse tipo de construção decorre do tipo de elicitação utilizada no trabalho ${ }^{5}$.
a) Dâw xut mũm
dâw tee-ũuy'
gente macho abraçar
gente filho-MDO
'O homem abraçou a criança'

\footnotetext{
${ }^{5}$ Para mais detalhes, ver seção 2.2 .2 do capítulo 2 .
} 


\section{b) Dâw tee mũm wâsoer \\ gente filho abraçar fácil \\ 'Criança abraça com facilidade'}

As construções médias em Dâw estão associadas a construções intransitivas, em conformidade com o que foi discutido em Kemmer (1993, 1994) e Maldondo (2006, 2007). Diferentemente da construção reflexiva, que exige a presença de dois argumentos, a voz média possui apenas um argumento, que é afetado pelo evento verbal. Assim, as médias em Dâw remetem a ações que envolvem somente o sujeito que é argumento interno do verbo, por isso sua semântica não é agentiva, mas de paciente.

\subsubsection{Construção passiva}

A construção passiva não ocorre em Dâw. Essa voz não é entendida pelos informantes testados e quando pedimos aos informantes uma sentença com leitura passiva, dois tipos de sentenças foram produzidas: i) uma sentença incoativa (sentença 28 e 29); ii) uma sentença com sujeito subespecificado (sentença 30 e 31$)^{6}$.

Exemplos:

a) Dâw xut rõk tor-ũuy'
gente macho cortar porco-MDO
'O homem cortou o porco

b) Tor rõk yed

porco cortar ASPC

'O porco cortou'

\footnotetext{
${ }^{6}$ Além dos dois tipos de sentenças citados, também foi produzido a seguinte sentença:

i) Tor rõk rãm

porco cortar ir

'O porco foi cortar'
}

Nessa sentença, o informante parafraseou a estrutura da voz passiva existente no português brasileiro, ou seja, 'sujeito + auxiliar + verbo'. Todavia, a leitura apresentada pela sentença não expressa uma eventualidade passiva. Mais precisamente, tal estrutura não é compatível com a leitura de uma ação sofrida pelo argumento interno realizada por um individuo, que, quando representado sintaticamente, é expresso em um tipo de adjunção normalmente aludida como 'agente da passiva'. Dessa forma, não analisamos essa sentença como uma construção com leitura passiva, mas a analisamos como uma paráfrase estrutural da passiva existente em português. 
(29)

a) Yam yũt nu-ũuy

'O cachorro matou o rato'

b) Nu kasãm

Rato morrer

'O rato morreu'

(30)

a) Dâw xut wây pũug

gente macho ver porco

'O homem viu o porco espinho'

b) Dâw wây pũug

gente ver porco

'Alguém viu o porco'

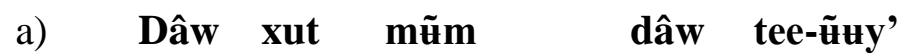

gente macho abraçar gente filho-MDO

'O homem abraçou a criança'

b) Rid mũm dâw tee-ũuy'

3PL abraçargente filho-MDO

'Eles abraçaram a criança'

As construções produzidas pelos informantes claramente não são construções passivas, mas sentenças que se assemelham a esses tipos de sentenças. Como foi visto anteriormente, Keenan \& Dryer (2007) mostram que línguas que não conceitualizam eventualidades como a passiva, realizam esses tipos de eventos com outras construções semelhantes. No caso do Dâw, as construções produzidas não são exemplos de passivas, como a entendemos, pois os eventos codificados nas construções supracitadas são eventos intransitivos em que há a demoção sintática e semântica do sujeito da construção transitiva (exemplos 28 e 29), ou apenas a demoção semântica, uma vez que há uma subespecificação do sujeito para um argumento agente para um argumento genérico, como visto nos exemplos (30) e (31). 
Os dados de Martins (2004), por sua vez, também sugerem essa análise, uma vez que as construções passivas em Dâw não ocorrem com o agente da passiva. Como vimos anteriormente, uma das principais caraterísticas da passiva é a exigência semântica de um agente da passiva. Sua inaceitabilidade nessas construções demonstra que as sentenças presentes em Dâw não podem ser passivas, mas sentenças incoativas.

\subsection{Síntese do capítulo}

As análises acerca dos processos de intransitivização em Dâw mostraram que não há morfologia específica para a construção de sentenças médias, incoativas. Além disso, não existem passivas em Dâw. No lugar dessa voz, os falantes produzem sentenças incoativas ou com o sujeito subespecificado. Por fim, as sentenças reflexivas são geradas por meio de pronomes reflexivos na posição de objeto da sentença. Além disso, constatamos que o apagamento do tom de verbos transitivos não reduz a valência verbal. As mudanças tonais decorrem de padrões tonais previsíveis que seguem regras fonológicas que atuam no nível da frase fonológica, como foi discutido no capítulo 4 . 


\section{Capítulo 7: A marcação de objeto em Dâw}

\subsection{Introdução}

Neste capítulo, abordamos a marca de objeto \{-üty'\} que ocorre com objetos diretos de sentenças transitivas e com objetos indiretos de sentenças bitransitivas. Segundo Martins (2004), \{-ũtty'\} marca caso afetado cuja função é "marcar o constituinte que é afetado pelo evento que o verbo exprime" (MARTINS, 2004:498).

Elicitamos as ocorrências desse morfema em sentenças transitivas e bitransitivas nos trabalhos de campo realizados durante esta pesquisa. Observamos que, com o objeto

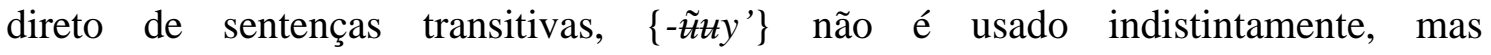
majoritariamente em contextos semânticos de animacidade e definitude.

Devido a essa propriedade semântica, analisamos o morfema supracitado como uma Marcação Diferencial de Objeto (doravante MDO). Segundo Aissen (2003), Bossong (1999), entre outros, essa marca está associada aos objetos diretos de sentenças transitivas e é empregada de acordo com traços semânticos de definitude e animacidade do objeto.

Conforme veremos, a MDO também ocorre em duas outras línguas da família Nadahup - Hup e Yuhup - o que evidencia que esse não é um fenômeno isolado na língua Dâw dentro da sua família linguística.

Com objetos indiretos, $\{$-zuny'\} não é uma MDO, mas um morfema oblíquo de forma homófona. Possivelmente, a origem histórica do morfema MDO seja o morfema oblíquo. Hoje, trata-se de dois morfemas distintos, mas homófonos.

Na seção 7.1, apresentamos a definição e a descrição de Martins (2004) quanto ao sufixo de caso afetado em Dâw. Na seção 7.2, definimos MDO de acordo com a literatura (Bossong 1999, Aissen 2003). Na seção 7.3, apresentamos o funcionamento da MDO em duas línguas da família Nadahup - Yuhup e Hup. Na seção 7.4, apresentamos os protocolos de elicitação e os resultados dos testes formulados para estudar o caso afetado em Dâw; na seção, 7.5, analisamos o sufixo \{-ütry'\} como uma MDO, tendo em vista o padrão de marcação de objetos diretos de sentenças transitivas. 


\subsection{0 morfema de caso afetado $\{-\tilde{u} \nVdash y '\}$}

Segundo Martins (2004), o morfema de caso afetado \{-üty'\} é um sufixo que marca um constituinte afetado pelo evento verbal. Esse constituinte pode ser um objeto direto (em sentenças transitivas, exemplos 1 e 2), um objeto indireto (em sentenças bitransitivas, exemplo 3 ) e um adjunto (exemplo 4$)^{1}$.

Exemplos:

(1)

$\begin{array}{lllll}\text { tir } & \text { wâ'-kâat } & \text { dâar } & \text { nũux } & \text { - } \\ \text { 3SG } & \text { em cima-ficar em pé } & \text { PONT } & \text { curupira } & \text {-AFET }\end{array}$

'Ele pisa na cabeça do curupira'

(MARTINS, 2004: 498)

(2)

$$
\begin{array}{llll}
\mathbf{y}^{\prime} \mathbf{a} \mathbf{m} \mathbf{x u} & \text { rãa' } & \text { dâar } & \text { tir-ũuy' } \\
\text { onça } & \text { deixar } & \text { PONT } & \text { 3SG-AFET }
\end{array}
$$

'Ai, a onça soltou-o de uma vez'

$$
\begin{array}{lllll}
\text { woor } & \text { nõo } & \text { tir- } \mathbf{u} \text { y' } & \text { yuun } & \text { kâs } \\
\text { NP } & \text { dar } & \text { 3SG-AFET } & \text { roupa } & \text { velha } \\
\text { 'O Tukano dá roupa velha para ele' }
\end{array}
$$

(MARTINS, 2004: 268)

(MARTINS, 2004: 221)

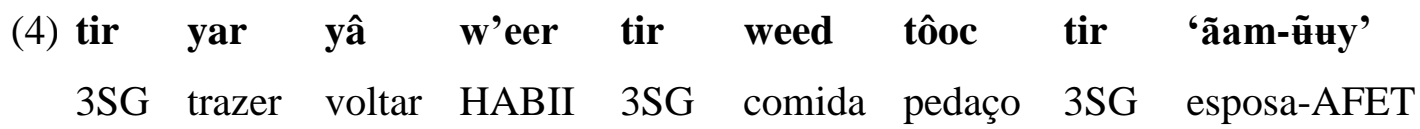

'Ele sempre trazia resto de comida para a mulher dele'

(MARTINS, 2004: 300)

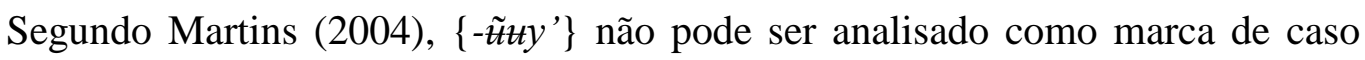
acusativo, pois ele também ocorre com adjuntos (cf. nota 1). Para a autora, o caso afetado marca o constituinte afetado pela ação verbal. Dessa forma, em uma sentença transitiva e/ou bitransitiva, o sujeito não será marcado pelo sufixo, mas o objeto será. De acordo com Martins (2004), o emprego de $\{-\tilde{u} u y\}$ com objetos é opcional. No

\footnotetext{
${ }^{1}$ Segundo Martins (2004), o verbo yar 'trazer' é um verbo transitivo e não requer a codificação do alvo da ação: trazer algo para alguém. Por isso o sintagma tir 'ãam-üty' 'a esposa dele' configura-se como um adjunto.
} 
entanto, a autora não informa se o seu uso é opcional ou obrigatório com objetos diretos (sentenças transitivas), indiretos (sentenças bitransitivas) e adjuntos.

Analisamos as ocorrências do uso de $\{-\tilde{u} u y '\}$ em Martins (2004) e percebemos que objetos indiretos de sentenças bitransitivas sempre são marcados. Diferentemente de objetos diretos (sentenças transitivas), que ora são marcados por $\{-\tilde{t} z y$ '\}, ora não são. Adjuntos recebem a marca de afetado, mas também podem ser marcados por outros tipos de posposições. Assim, em relação aos objetos, a opcionalidade do morfema de caso afetado referida por Martins (2004) relaciona-se aos objetos diretos de sentenças transitivas apenas.

Com relação à opcionalidade da marca de objeto, como veremos adiante, algumas línguas marcam de forma distinta objetos diretos de sentenças transitivas. Todavia, essa distinção morfológica está condicionada à semântica do constituinte marcado. Desse modo, objetos não prototípicos (que possuem traços semânticos de animacidade e definitude) são marcados por uma morfologia específica, pois eles teriam propriedades semânticas semelhantes às dos sujeitos do evento verbal. Objetos prototípicos (inanimados e indefinidos, características incompatíveis com um agente ou uma causa) não precisariam ser marcados. Nesse sentido, a marca de caso estaria condicionada a dois fatores: sintático, relacionado ao papel estrutural desse constituinte na sentença; e semântico, relacionado ao papel temático desempenhado pelo constituinte na sentença.

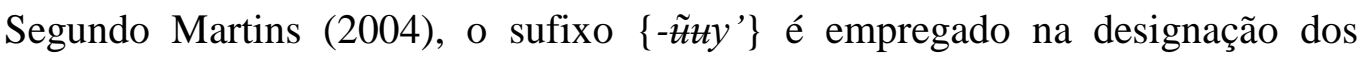
pronomes oblíquos. Para ela, o pronome usado para a primeira pessoa do singular

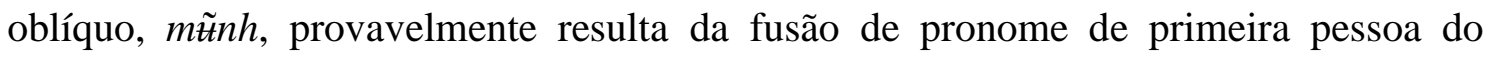

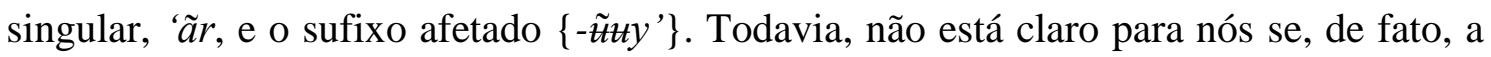
forma oblíqua derivada é formada a partir da composição da primeira pessoa do singular e do sufixo afetado, uma vez que não encontramos evidências fonológicas da forma da primeira pessoa do singular no pronome oblíquo mĩuh

Segundo a autora, a segunda pessoa do singular oblíquo apresenta duas formas,

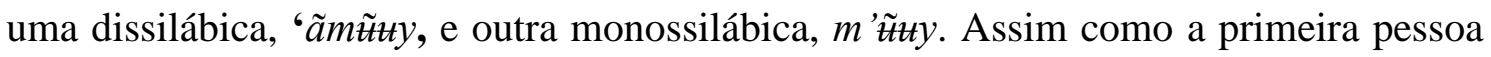
do singular, suas formas resultam da fusão de $\{-\tilde{t} t y$ ' $\}$ e do pronome de segunda pessoa do singular, ‘ $\tilde{a} m$. 
Exemplos:

(5)
'ãr raan wut m'ũuy
1SG avisar FRUST 2SG.OBL

'Eu tentei avisá-lo'

(MARTINS, 2004:499)

$\begin{array}{llrl}\text { (6) 'ãm } & \text { rãa' } & \text { 'êey } & \text { mũunh } \\ \text { 2SG } & \text { deixar } & \text { FUT } & \text { 1SG.OBL } \\ \text { 'Você vai me deixar' }\end{array}$

(MARTINS, 2004:499)

Em Dâw, a ordem básica de orações declarativas é SVO. No entanto, quando o argumento objeto é deslocado para a posição pré-verbal, ele deve ocorrer com o sufixo afetado $\{-\tilde{u} u y '\}$.

Exemplo:

$\begin{array}{llllll}\text { 'ãm } & - \text { '̃uy } & \text { kâs } & \text { yed } & \text { yãm } & \text { xu' } \\ \text { 2SG } & \text {-AFET } & \text { morder } & \text { INTSI } & \text { cachorro verdadeiro } \\ \text { 'A você, foi onça que o mordeu' }\end{array}$

(MARTINS, 2004:500)

De acordo com Martins (2004), nessa posição, o argumento teria seu grau de 'afetação' aumentado, por isso, o constituinte deslocado deve ser marcado por $\{-\tilde{z} z y$ '\}. Todavia, acreditamos que o emprego de $\{-\tilde{t} t y$ ' $\}$ marca objetos em uma posição não prototípica, isto é, em posição pré-verbal.

Tendo em vista os ambientes de ocorrência de $\{-\tilde{u} u y '\}$, acreditamos que o caso afetado em Dâw pode ser analisado como um fenômeno conhecido como MDO, que ocorre em várias línguas do mundo ${ }^{2}$. Nas próximas seções ${ }^{3}$, apresentaremos as propriedades da MDO e iremos correlaciona-las com as propriedades do caso afetado \{üuy'\} em Dâw.

\footnotetext{
${ }^{2}$ Exemplos: Mandarim (cf.IEMMOLO \& ARCODIA, 2014), Aramaico Moderno (cf. COGHILL, 2014); Espanhol (cf. AISSEN, 2003); Hebraico (cf. MINUSSI, 2009) e Armênio (Cf. YEGHIAZARYAN, 2005).

${ }^{3}$ Da seção 7.2 em diante, utilizaremos a glosa MDO para o morfema \{-zutuy'\} quando ele ocorre como objeto direto, e OBL quando ocorre como objeto direto ou adjunto, modificando, portanto, o rótulo de Martins (2004).
} 


\subsection{Definindo MDO}

Segundo Aissen (2003) ${ }^{4}$, a MDO é uma marca de caso associada aos objetos de sentenças transitivas e é empregada de acordo com traços semânticos do objeto marcado. Esses traços estão relacionados às escalas de definitude e animacidade.

a) Escala de Animacidade: Humano>Animado>Inanimado

b) Escala de Definitude: Pronome Pessoal, Nome Próprio, NP definido>NP indefinido e específico>NP não-específico.

(AISSEN, 2003:437)

A princípio, os objetos que apresentam os traços semânticos mais altos nessas escalas são marcados. Todavia, nota-se que as línguas, no que diz respeito ao emprego de MDO, não possuem uniformidade em relação às escalas semânticas apresentadas. Algumas línguas marcam todos os objetos, outras marcam apenas uma parte deles. Há aquelas que obedecem a apenas uma escala semântica, seja de definitude ou animacidade, ou que obedecem a ambas as escalas.

Aissen (2003) afirma que a MDO aparece de muitas formas, incluindo três tipos básicos, que são:

a) Singalês: a marcação de caso é opcional, mas somente objetos animados podem ser marcados;

b) Hebraico: a marcação de caso é obrigatória, mas é limitada aos objetos definidos;

c) Romeno: a marcação de caso é obrigatória para alguns objetos, opcional para outros e excluída para um terceiro grupo. Entre os obrigatórios, estão os pronomes pessoais animados e nomes próprios.

(AISSEN, 2003:436)

Segundo Bossong (1999) ${ }^{5}$, em línguas com MDO, os objetos diretos que possuem uma semântica semelhante à dos sujeitos prototípicos, ou seja, os que são [+animado] e [+definido], são marcados morfologicamente por morfemas que não ocorreriam com objetos prototípicos, [-animados], [-definidos]. Nesse sentido, os objetos não prototípicos são marcados morfologicamente para serem distinguidos dos

\footnotetext{
${ }^{4}$ A autora aborda o funcionamento da MDO nas línguas Indo-europeias como o Persa, Hindi e o Espanhol.

${ }^{5} \mathrm{O}$ autor aborda o funcionamento da MDO nas famílias linguísticas Românicas e Semíticas.
} 
sujeitos. Desse modo, a marcação não permitiria expressar uma possível ambiguidade entre os dois constituintes.

Para Aissen (2003), essa intuição pode ser entendida de outra forma: as propriedades que motivam a marcação de objetos com MDO são exatamente aquelas que não motivam a marcação do sujeito. Desse modo, os objetos que possuem propriedades similares às do sujeito (animacidade e definitude) são marcados. Sujeitos não são marcados, pois eles são prototipicamente animados e definidos. Assim, não haveria a necessidade de marcar, morfologicamente, uma categoria prototípica de um elemento. Aissen (2003) denomina essa característica de marcação inversa.

\section{- Iconicidade e Economia}

Segundo Aissen (2003), a MDO possui dois tipos de restrições: a iconicidade e a economia.

a) Restrição da Iconicidade: objetos marcados morfologicamente com MDO são mais complexos em relação àqueles que não são marcados pelo morfema de objeto. Ou seja, o sistema linguístico favorece a marcação morfológica de estruturas proeminentes.

b) Restrição da Economia: a marcação de caso é evitada, deixando a obrigatoriedade apenas para aqueles objetos que precisam de tal marcação.

Segundo Aissen (2003), a MDO ocorre em línguas que possuem sistema de caso morfológico. Nessas línguas, a morfologia acusativa está condicionada à semântica do objeto direto do verbo.

Segundo Bossong (1991), quando a morfologia de caso desaparece em uma língua, e a distinção formal entre sujeito e objeto não está explícita na morfologia, ocorre um dos processos mostrados abaixo:

a) Substituição por posição: sujeito e objeto são identificados devido à sua posição fixa dentro da sentença.

b) Substituição por morfologia: sujeito e objeto são marcados por morfemas de outro tipo.

Segundo o autor, nas línguas românicas e semíticas com substituição gramatical, uma parte dos objetos diretos é marcada por caso, enquanto a outra parte não é marcada, 
desenhando um quadro no qual haveria um sistema de Caso acusativo diferencial. É esse sistema que o autor denomina de MDO.

Bossong (1999) afirma que nas línguas românicas, o surgimento da MDO remonta ao Latim Clássico ou Vulgar, no qual Caso dativo intercambiava com a forma de Caso acusativo, e o morfema de Caso acusativo intercambiava com uma construção do tipo preposição + acusativo. Dessa forma, podemos perceber que nas línguas românicas, a MDO, de algum modo, está relacionada com a marcação de oblíquo seja pela preposição, seja pelo caso dativo.

No que se refere à semântica desses objetos, mais especificamente à definitude, Lyons (1999 apud Minussi 2009) apresenta o conceito de familiaridade ou identificabilidade que nos ajuda a entender o papel da definitude na marcação morfológica do objeto. Para o autor, a definitude de um NP pode ser expressa por vários elementos de uma língua. No caso do inglês, por exemplo, a noção de (in)definitude é expressa por artigos, como the e $a$, sendo que the indica um NP definido e $a$ um NP indefinido. No entanto, nas sentenças:

(8) I bought a car this morning

(9) I bought the car this morning

O sintagma 'a car' não denota uma entidade qualquer, mas uma entidade específica que foi comprada pelo falante. De algum modo, 'the car' é mais definido ou específico que 'a car', mas ambos os sintagmas denotam entidades específicas para o falante.

Desse modo, para o autor, a noção que tanto falante quanto ouvinte tem sobre uma entidade do discurso influencia no modo como é interpretada a (in)definitude dessa mesma entidade. Essa noção está por trás do que Lyons (1999) analisa como a ideia de familiaridade e identificabilidade.

\section{- Familiaridade e identificabilidade}

Familiaridade é uma noção que indica que tanto o falante quanto o ouvinte tem consciência do objeto sobre o qual se fala, o que gera uma leitura definida. Identificabilidade é uma noção que indica um cenário no qual o falante conhece a entidade sobre a qual se fala, mas o ouvinte não. Dessa forma, a entidade referida pelo 
falante é definida, mas para o ouvinte não, mas pode passar a ser quando o ouvinte encontrar o referente no mundo para essa entidade.

Assim, tomando a noção de familiaridade e identificabilidade de Lyons (1999), podemos fazer a seguinte distinção de cenários quanto à leitura de definitude de um NP:

a) Definido (familiar) - falante e ouvinte conhecem o referente da entidade referida pelo discurso;

b) Definido (identificável) - só o falante conhece o referente da entidade referida pelo discurso, o ouvinte não;

c) Indefinido - nem falante nem ouvinte conhecem o referente da entidade referida pelo discurso.

\subsection{MDO nas línguas Nadahup - Yuhup e Hup}

De acordo com Epps (2005) e Ospina (2002), as línguas Hup e Yuhup possuem MDO. As autoras analisam essas marcas como morfologia de Caso acusativo com restrições semânticas de acordo com o grau de definitude e animacidade do objeto. Em Yuhup, os NPs objetos são marcados pelo morfema $\{-d i h\}$. Já em Hup os objetos são marcados pelo morfema $\{-\check{a} n\}$.

Nas duas línguas Nadahup, os NPs objetos marcados pelos morfemas supracitados são: pronomes, nomes acompanhados de pronome demonstrativo e nomes próprios de indivíduos e de parentesco. Nomes comuns de animais são opcionalmente marcados. Nomes próprios de animais recebem marcação. Nomes de entidades inanimadas ou indefinidos não a recebem.

A seguir, apresentamos os exemplos para as duas línguas citadas ${ }^{6}$ :

\section{- Pronomes ou NP com demonstrativo}

(8) a) Yuhup

〜jìdŏh- dìh tíh ìhkéjí

3PL-ACC 3SG cumprimentar

'Ele os cumprimenta'

(OSPINA, 2002: 144)

\footnotetext{
${ }^{6}$ Os morfemas MDO dos exemplos extraídos de Ospina (2002) e Epps (2005) foram sublinhados.
} 
b. Hup

Pãh hipấh-ấy yúw-

1SG conhecer-DYNM este.ITG-OBJ-DECL

'Eu conheço esta (história)'

(EPPS, 2005: 232)

- Nomes próprios e de parentesco

(9) a. Yuhup

wôj $^{\mathbf{n}}$ ùb $^{\mathbf{m}} \mathbf{i} \quad$ ìhoww- $\underline{\text { dìh }}$

Won acertar Ihow-ACC

'Won acertou Ihow'

(OSPINA, 2002: 144)

b. Hup

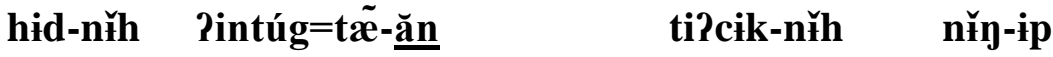

3pl-POSS marido da mãe=filho-OBJ repugnar-NEG 2PL-DEP

'Vocês não repugnam seu padrasto'

(EPPS:2005:232)

- Nomes de animais

(10) a. Yuhup

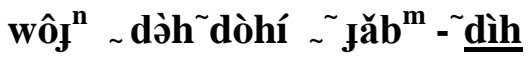

Won derrubou onça-ACC

'Won derrubou a onça'

(OSPINA, 2002: 146)

b. Hup

tin-ǐh cápu-ăn=y̌̃? tih Péy-cud?ữhníy

3SG.POSS sapo(Pt)-OBL=TEL 3SG chamar-INFR2.talvez

'Ele aparentemente chamou pelo seu sapo'

(EPPS, 2005: 236)

- Nomes inanimados

(11) a. Yuhup

Jâp déh bòh _wób ${ }^{\text {mí }}$

3SG água derramar

'Eu derramei água'

(OSPINA, 2002:142) 


\section{b. Hup}

yikán mǒy hid bi?-přd-řh, póg!

lá casa 3PL fazer-DIST-DECL grande

'Lá eles construíram a casa, (ela era) grande!'

(EPPS, 2005: 236)

Nas construções transitivas do Yuhup, a marcação do objeto está condicionada à semântica dos objetos e à semântica do sujeito. Assim, a marcação do objeto ocorre sempre que o objeto for animado e definido, independentemente de o sujeito ser animado e/ou definido, indefinido e/ou inanimado. O objeto não será marcado se ele for indefinido e inanimado, e o sujeito for animado e definido. Abaixo, apresentamos os contextos de marcação do objeto por $\{d i h\}$.

\begin{tabular}{l|l}
\hline \multicolumn{1}{c|}{ Objeto marcado por $\{$ dìh $\}$} & \multicolumn{1}{c}{ Objeto não marcado por \{dìh\} } \\
\hline Sujeito [+animado]; Objeto [+animado] & Sujeito [+animado]; Objeto [-animado] \\
\hline Sujeito [+definido]; Objeto [+definido] & Sujeito [+definido]; Objeto [-definido] \\
\hline Sujeito [+agentivo]; Objeto [+agentivo] & Sujeito [+agentivo]; Objeto [-agentivo] \\
\hline Sujeito [-animado]; Objeto [+animado] & \\
\hline Sujeito [-agentivo]; Objeto [+agentivo] & \\
\hline
\end{tabular}

Tabela 7.0: Contextos de marcação do objeto por \{dih\} em Yuhup segundo Ospina (2002)

Nas sentenças bitransitivas de Hup e Yuhup, o objeto indireto (alvo) é sempre marcado pelo morfema de objeto. No entanto, o objeto direto (tema), em ambas as línguas é marcado apenas quando for definido e/ou animado.

- Sentenças bitransitivas

\section{a. Yuhup}

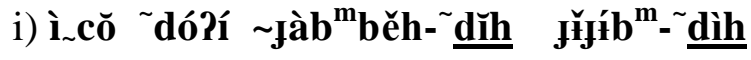

Icho dar cão-ACC Jujubm-ACC

'Icho deu o cão a Jujubm'

(OSPINA, 2002:147)

ii) ì cŏ “wêd ${ }^{\mathrm{n}}$ ¿ó?í dójâp- “ $\underline{\text { dìh }}$

Icho comida dar criança-ACC

'Icho deu a comida à criança'

(OSPINA, 2002:147) 


\section{b. Hup}

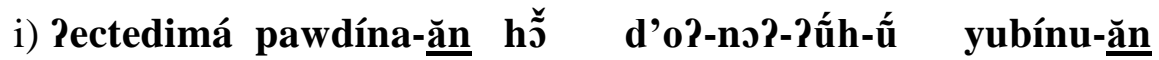

Esterimar Paulina-OBJ peixe dar-APPL-DYNM Jovino-OBJ

'Esterimar deu peixe para Paulina de Jovino'

(EPPS, 2005: 229)

ii) tiyǐ? cadakă?-ăn pihiyúm nó?-óy

homem galinha-OBJ milho dar-DYNM

'O homem dá milho para a galinha'

(EPPS, 2005: 227)

Por fim, em Hup, os adjuntos também podem ser marcados pelo morfema de objeto.

- Adjuntos

\section{a. HUP}

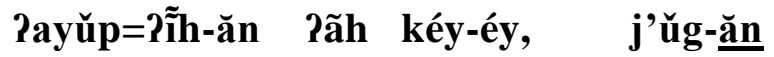
um=MSC-OBJ $1 \mathrm{SH}$ ver-DYNM floresta-OBJ

'Eu vi um homem na floresta'

(EPPS, 2005: 234)

A marca de objeto em Hup possui homofonia segmental com o morfema oblíquo $\{-a n\}$, que, de acordo com a autora, é usado para expressar caso ablativo e locativo em Hup. A semelhança fonológica entre o morfema oblíquo e a MDO em Hup revela a possibilidade de uma origem em comum a ambos os morfemas, como aponta Epps (2005):

A forma $-a n$ é fonologicamente quase idêntica ao caso de objeto -ăn, diferenciando-se apenas do seu sufixo cognato pela falta de tom. As duas formas são provavelmente próximas historicamente, mas sincronicamente elas são distintas, não apenas na forma, mas também nos seus padrões funcionais e semânticos ${ }^{7}$. (EPPS, 2005:242)

Em Yuhup, observamos um cenário semelhante de homofonia. De acordo com Ospina (2002), em Yuhup, o morfema acusativo $\{-d i h\}$ e oblíquo possuem formas homófonas. Para Ospina (2002), objetos indiretos são marcados pelo morfema oblíquo,

\footnotetext{
7 Tradução nossa. "The form -an is phonologically almost identical to the Object case marker -ăn, differing from its sister suffix only in its lack of stress. The two are probably closely related historically, but synchronically they are distinct, not in their form but also in their functions and semantic patterning”.
} 
e não pela MDO, por isso que, nesse tipo de marcação, não haveria restrição semântica em relação ao objeto.

\subsection{Estudo do uso de $\{-\tilde{u} \sharp y '\}$ em Dâw}

Fizemos um levantamento das ocorrências do morfema $\{-\tilde{u} z y$ ’\} em sentenças transitivas e bitransitivas presentes em Martins (2004). A observação dessas ocorrências nos levou à hipótese de que o morfema de caso afetado possui comportamento semelhante ao apresentado pela MDO em Hup e Yuhup. Em uma análise preliminar dos dados apresentados por Martins (2004), observamos que em Dâw, os objetos marcados por $\{-\tilde{t} t y$ '\} são, principalmente: pronomes, nomes acompanhados de pronome demonstrativo e nomes próprios de indivíduos e de parentesco. Nomes comuns de animais são opcionalmente marcados. Nomes de entidades inanimadas ou indefinidos não costumam ser marcados.

A fim de refutar ou corroborar a hipótese levantada pela observação dos dados do morfema de caso afetado em Martins (2004), nos trabalhos de campo realizados em julho de 2013 e em janeiro e fevereiro de 2014, elaboramos três procedimentos de elicitação de dados, dois para elicitar sentenças transitivas, e um para elicitar sentenças bitransitivas.

\subsubsection{Elicitação de dados}

Os procedimentos de elicitação de dados para sentenças transitivas foram:

i) Elicitação com controle situacional das sentenças;

ii) Elicitação com colocação de figuras e explanação de ações ${ }^{8}$.

O procedimento de elicitação de dados para sentenças bitransitivas foi:

i) Teste de (a)gramaticalidade com sentenças elaboradas na língua em estudo.

\footnotetext{
${ }^{8}$ Este teste foi adaptado do teste experimental para elicitação de relativas de sujeito e objeto elaborado por VIVANCO, K. (2014).
} 


\section{Elicitação de sentenças transitivas}

\section{i) Elicitação com controle situacional das sentenças}

O procedimento de elicitação de dados com controle situacional de sentenças foi realizado com três informantes, que serão identificados por $\mathrm{V}, \mathrm{S}$ e $\mathrm{P}$. O protocolo de elicitação foi elaborado da seguinte forma:

i. Elicitamos sete sentenças em três contextos situacionais distintos baseando-nos na noção de definitude discutida em Lyons (1999). Contexto 1: definido (familiar); contexto 2: definido (identificável); contexto 3: indefinido.

ii. As sete sentenças elicitadas diferenciaram-se apenas pela natureza do objeto que foi dividido em três categorias, de acordo com a sua posição na escala de animacidade: humano animado (HA); animal animado (AA); inanimado (I). Subdividimos as categorias humano animado em três subcategorias: nome comum; nome próprio e pronome.

iii. Subdividimos as categorias animal animado e inanimado em duas subcategorias: nome comum e determinante (aquele(a), um(a)) + nome.

Cada sentença elicitada foi inserida em um cenário. Os cenários foram formulados para que o informante tivesse em mente os contextos situacionais preteridos para cada sentença. Depois de fornecido um cenário, fornecíamos ao informante a sentença em português e pedimos a tradução em Dâw dessa sentença. No total, elicitamos sete sentenças no contexto 1 e 2 e cinco sentenças no contexto 3 , totalizando 19 sentenças elicitadas ${ }^{9}$.

A seguir, apresentamos os protocolos de elicitação elaborados.

\footnotetext{
${ }^{9}$ Como o contexto 3 se refere a um cenário de não-definitude e não-especificidade, não achamos necessária a divisão em subcategorias NP e DP para os objetos inseridos na categoria animal animado e inanimado, uma vez que, em português, a leitura indefinida e não-especifica sem o determinante um(a) deixa a sentença duvidosa.
} 
CONTEXTO 1: DEFINIDO (FAMILIAR)

Falante e ouvinte conhecem o objeto

\begin{tabular}{|c|c|c|c|}
\hline $\begin{array}{c}\text { Categoria do } \\
\text { objeto }\end{array}$ & $\begin{array}{c}\text { Subcategoria } \\
\text { do objeto }\end{array}$ & Cenário & $\begin{array}{l}\text { Sentenças } \\
\text { elicitadas }\end{array}$ \\
\hline \multirow[t]{3}{*}{$\begin{array}{l}\text { Humano } \\
\text { Animado }\end{array}$} & NP comиm & $\begin{array}{l}\text { Nós dois vimos uma mulher } \\
\text { loira de olhos azuis na } \\
\text { cidade. Ela nos chamou a } \\
\text { atenção, porque ela era a } \\
\text { única mulher com essa } \\
\text { aparência. À tarde, você a viu } \\
\text { no porto da comunidade. De } \\
\text { noite, quando você veio me } \\
\text { visitar na minha casa, você } \\
\text { me disse: "Eu vi a mulher". }\end{array}$ & $\begin{array}{lll}\text { (1) } \quad \text { Eu } & \text { vi } & \text { a } \\
\text { mulher } & & \end{array}$ \\
\hline & NP próprio & \multirow{2}{*}{$\begin{array}{l}\text { A Auxiliadora }{ }^{10} \text { chegou à } \\
\text { comunidade hoje. Você a viu } \\
\text { hoje de manhã no porto. À } \\
\text { tarde, quando você me } \\
\text { encontrou na minha casa, } \\
\text { você me disse: "Eu vi a } \\
\text { Auxiliadora"; "Eu vi ela". }\end{array}$} & $\begin{array}{l}\text { (2) } \quad \mathrm{Eu} \quad \text { vi } \quad \mathrm{a} \\
\text { Auxiliadora }\end{array}$ \\
\hline & $D P$ & & (3) Eu vi ela \\
\hline \multirow[t]{2}{*}{ Animal Animado } & $N P$ & \multirow[b]{2}{*}{$\begin{array}{l}\text { Nós dois saímos de manhã e } \\
\text { vimos perto da casa da } \\
\text { Auxiliadora uma anta. À } \\
\text { noite, quando você veio me } \\
\text { visitar, você viu a mesma } \\
\text { anta que vimos naquela } \\
\text { manhã. Assim que você me } \\
\text { vê, você fala para mim: "Eu } \\
\text { vi a anta"; "Eu vi aquela } \\
\text { anta". }\end{array}$} & (4) Eu vi a anta \\
\hline & $D P$ & & $\begin{array}{l}\text { (5) Eu vi aquela } \\
\text { anta }\end{array}$ \\
\hline \multirow[t]{2}{*}{ Inanimado } & $N P$ & \multirow[b]{2}{*}{$\begin{array}{l}\text { Ontem à tarde, nós dois } \\
\text { encontramos a Auxiliadora. } \\
\text { Ela nos mostrou um colar, o } \\
\text { único, que ela tinha feito. À } \\
\text { noite, você viu a Tatiane com } \\
\text { o mesmo colar que a } \\
\text { Auxiliadora nos mostrou na } \\
\text { tarde de ontem. Em seguida, } \\
\text { você me vê e diz: "Eu vi o } \\
\text { colar da Auxiliadora"; "Eu vi } \\
\text { aquele colar". }\end{array}$} & $\begin{array}{l}\text { (6) Eu vi o colar } \\
\text { da Auxiliadora }\end{array}$ \\
\hline & $D P$ & & $\begin{array}{l}\text { (7) Eu vi aquele } \\
\text { colar }\end{array}$ \\
\hline
\end{tabular}

Tabela 7.1: Protocolo de elicitação com controle situacional das sentenças contexto definido (familiar)

\footnotetext{
${ }^{10}$ Uma mulher conhecida por mim e pelo meu informante.
} 


\section{CONTEXTO 2: DEFINIDO (IDENTIFICÁVEL)}

Só falante conhece o objeto

\begin{tabular}{|c|c|c|c|}
\hline $\begin{array}{c}\text { Categoria do } \\
\text { objeto }\end{array}$ & $\begin{array}{c}\text { Subcategoria } \\
\text { do objeto }\end{array}$ & Cenário & $\begin{array}{l}\text { Sentença } \\
\text { elicitada }\end{array}$ \\
\hline \multirow[t]{3}{*}{$\begin{array}{l}\text { Humano } \\
\text { Animado }\end{array}$} & NP comum & \multirow{3}{*}{$\begin{array}{l}\text { Uma mulher chamada Ana } \\
\text { chegou na comunidade } \\
\text { ontem. Eu fui vê-la chegar no } \\
\text { porto. Você não foi. À noite, } \\
\text { eu fui a sua casa e te disse: } \\
\text { "Eu vi a Ana"; "Eu vi ela"; } \\
\text { "Eu vi a mulher". }\end{array}$} & $\begin{array}{llll}(8) \quad \text { Eu } & \text { vi } & \text { a } \\
\text { mulher } & & \end{array}$ \\
\hline & NP próprio & & (9) Eu vi a Ana \\
\hline & $D P$ & & (10) Eu vi ela \\
\hline \multirow[t]{2}{*}{ Animal Animado } & $N P$ & \multirow[b]{2}{*}{$\begin{array}{l}\text { Corre o boato que tem uma } \\
\text { anta pela comunidade. De } \\
\text { manhã, antes de eu ir } \\
\text { trabalhar, eu vi a anta perto } \\
\text { da minha casa. À noite, } \\
\text { quando eu fui à sua casa, eu } \\
\text { te falei: "Eu vi a anta"; "Eu vi } \\
\text { aquela anta". }\end{array}$} & (11) Eu vi a anta \\
\hline & $D P$ & & $\begin{array}{l}\text { (12) Eu vi aquela } \\
\text { anta }\end{array}$ \\
\hline \multirow[t]{2}{*}{ Inanimado } & $N P$ & \multirow{2}{*}{$\begin{array}{l}\text { Eu vi a Auxiliadora ontem à } \\
\text { tarde e ela me mostrou o } \\
\text { colar que ela tinha feito. À } \\
\text { noite, eu vi a Tatiane usando } \\
\text { o mesmo colar. Quando eu } \\
\text { fui à sua casa, eu te disse: } \\
\text { "Eu vi o colar da } \\
\text { Auxiliadora"; "Eu vi aquele } \\
\text { colar". }\end{array}$} & $\begin{array}{l}\text { (13) Eu vi o colar } \\
\text { da Auxiliadora }\end{array}$ \\
\hline & $D P$ & & $\begin{array}{l}\text { (14) Eu vi aquele } \\
\text { colar }\end{array}$ \\
\hline
\end{tabular}

Tabela 7.2: Protocolo de elicitação com controle situacional das sentenças contexto definido e nãoespecífico 


\section{CONTEXTO 3: INDEFINIDO}

Nem destinador, nem destinatário conhecem o objeto

\begin{tabular}{|c|c|c|c|}
\hline $\begin{array}{l}\text { Categoria do } \\
\text { objeto }\end{array}$ & $\begin{array}{c}\text { Subcategoria } \\
\text { do objeto }\end{array}$ & Cenário & $\begin{array}{l}\text { Sentença } \\
\text { elicitada }\end{array}$ \\
\hline \multirow[t]{3}{*}{$\begin{array}{l}\text { Humano } \\
\text { Animado }\end{array}$} & NP comum & $\begin{array}{l}\text { O Mateus viu uma mulher } \\
\text { loira no porto da comunidade } \\
\text { que nem eu nem você } \\
\text { conhecemos. À noite, ele nos } \\
\text { encontrou e nos disse: "Eu vi } \\
\text { uma mulher loira"; "Eu vi } \\
\text { uma mulher" }\end{array}$ & $\begin{array}{l}\text { (15) Eu vi uma } \\
\text { mulher }\end{array}$ \\
\hline & NP próprio & \multirow{2}{*}{$\begin{array}{l}\text { Uma mulher chamada Ana } \\
\text { chegou à comunidade. Nem } \\
\text { eu, nem você conhecemos } \\
\text { essa mulher. O Mateus viu } \\
\text { essa mulher à noite no porto. } \\
\text { Pela manhã, ele nos viu e } \\
\text { falou: "Eu vi ela (estávamos } \\
\text { falando dela quando ele } \\
\text { chegou)"; "Eu vi a Ana" }\end{array}$} & (16) Eu vi a Ana \\
\hline & $D P$ & & (17) Eu vi ela \\
\hline Animal Animado & $D P$ & $\begin{array}{l}\text { O Mateus estava na mata e } \\
\text { viu uma anta. Quando ele } \\
\text { voltou, ele nos falou: "Eu vi } \\
\text { uma anta" }\end{array}$ & $\begin{array}{llll}\text { (18) } & \text { Eu vi uma } \\
\text { anta } & & & \end{array}$ \\
\hline Inanimado & $D P$ & $\begin{array}{l}\text { O Mateus foi para a cidade e } \\
\text { viu uma barraquinha cheia de } \\
\text { colares para vender. Quando } \\
\text { ele voltou, ele nos viu e disse: } \\
\text { "Eu vi um colar" }\end{array}$ & $\begin{array}{l}\text { (19) } \mathrm{Eu} \text { vi um } \\
\text { colar }\end{array}$ \\
\hline
\end{tabular}

Tabela 7.3: Protocolo de elicitação com controle situacional das sentenças contexto indefinido

Apresentamos os dados que cada informante forneceu para cada uma das 19 sentenças elicitadas.

Contexto 1: definitude (familiar)

Sentença (1): Eu vi a mulher

$$
\begin{aligned}
& \mathrm{V}-\tilde{A} r \text { wâay dâw ãy-ũuy } \\
& \text { 1PS ver gente mulher-MDO } \\
& \mathrm{S} \text { - ̃̂r wâay buuy ãy } \\
& \text { 1PS ver branco mulher } \\
& \mathrm{P} \text { - Ãr wâay buuy ãy } \\
& \text { 1PS ver branco mulher }
\end{aligned}
$$


Sentença (2): Eu vi a Auxiliadora

V - Ãr wâay koo-ũuy’

1PS ver Auxiliadora-MDO

S - Ãr wâay koo-ũuy'

1PS ver Auxiliadora-MDO

P - Ãr wâay koo-ũuy'

1PS ver Auxiliadora-MDO

Sentença (3): Eu vi ela

V - ̃̂r wâay tir-ũuy'

1PS ver 3PS-MDO

S - Ãr wâay tirũuy’

1PS ver 3PS-MDO

P - Ãr wâay tirũuy'

1PS ver 3PS-MDO

Sentença (4): Eu vi a anta

V - Ãr wâay taax uy-ũuy’

1PS ver anta ?-MDO

S - Ãr wâay taax

1PS ver anta

$\mathrm{P}$ - Ãr wâay taax

1PS ver anta

Sentença (5): Eu vi aquela anta

V - Ãr wâay aa taax uy-ũuy'

1PS ver DET anta ?-MDO

S - Ãr wâay aa taax-ũuy'

1PS ver DET anta-MDO

$\mathrm{P}$ - Ãr wâay aa taax

1PS ver DET anta 
Sentença (6): Eu vi o colar da Auxiliadora

$$
\begin{aligned}
& \mathrm{V}-\tilde{\mathrm{Ar}} \text { wâay koo kedrẽ } \\
& \text { 1PS ver Auxiliadora colar } \\
& \mathrm{S}-\tilde{A} \mathrm{r} \text { wâay koo kedrẽ } \\
& \text { 1PS ver Auxiliadora colar } \\
& \mathrm{P}-\tilde{\mathrm{A}} \mathrm{r} \text { wâay koo kedrẽ } \\
& \text { 1PS ver Auxiliadora colar }
\end{aligned}
$$

Sentença (7): Eu vi aquele colar

$$
\begin{array}{ccc}
\text { V - Ãr wâay aa } & \text { kedrẽ } \\
\text { 1PS ver } & \text { DET } & \text { colar } \\
\text { S- ̃̃r wâay } & \text { aa } & \text { kedrẽ } \\
\text { 1PS ver } & \text { DET } & \text { colar } \\
\text { P- ̃̃r wâay } & \text { aa } & \text { kedrẽ } \\
\text { 1PS ver } & \text { DET } & \text { colar }
\end{array}
$$

Contexto 2: definitude (identificável)

Sentença (8): Eu vi a mulher

$$
\begin{aligned}
& \text { V- Ãr wâay dâw ãy-ũuy } \\
& \text { 1PS ver gente mulher-MDO } \\
& \mathrm{S} \text { - ̃̂r wâay dâw ãy-ũuy } \\
& \text { 1PS ver gente mulher-MDO } \\
& \mathrm{P} \text { - ̃̂r wâay dâw ãy-ũuy } \\
& \text { 1PS ver gente mulher-MDO }
\end{aligned}
$$

Sentença (9): Eu vi a Ana

$$
\begin{aligned}
& \mathrm{V} \text { - ̃̃r wâay Ana-ũuy } \\
& \text { 1PS ver Ana-MDO } \\
& S \text { - Ãr wâay Ana-ũuy } \\
& 1 \text { PS ver Ana-MDO } \\
& \mathrm{P} \text { - ̃̃r wâay Dâw ta'-ũuy } \\
& \text { 1PS ver gente Ana(?)-MDO }
\end{aligned}
$$


Sentença (10): Eu vi ela

$\mathrm{V}$ - Ãr wâay tir-ũuy'

1PS ver 3PS-MDO

$\mathrm{S}-\tilde{\mathrm{Ar}}$ wâay tirũuy'

1PS ver 3PS-MDO

$\mathrm{P}-\tilde{\mathrm{Ar}}$ wâay tirũuy'

1PS ver 3PS-MDO

Sentença (11): Eu vi a anta

$\mathrm{V}$ - ̃̃r wâay aa taax-uy

1PS ver DET anta-?

$\mathrm{S}$ - ̃̂r wâay aa taax-ũuy'

1PS ver DET anta-MDO

$\mathrm{P}$ - ̃̂r wâay aa taax-ũuy'

1PS ver DET anta-MDO

Sentença (12): Eu vi aquela anta

V - Ãr wâay aa taax uy-ũuy'

1PS ver DET anta ?-MDO

$\mathrm{S}-\tilde{A} r$ wâay aa taax-ũuy'

1PS ver DET anta-MDO

$\mathrm{P}$ - ̃̃r wâay aa taax

1PS ver DET anta

Sentença (13): Eu vi o colar da Auxiliadora

$\mathrm{V}-\tilde{A} \mathrm{r}$ wâay koo kedrẽ

1PS ver Auxiliadora colar

$\mathrm{S}-\tilde{A} \mathrm{r}$ wâay koo kedrẽ

1PS ver Auxiliadora colar

$\mathrm{P}-\tilde{A} \mathrm{r}$ wâay koo kedrẽ

1PS ver Auxiliadora colar 
Sentença (14): Eu vi aquele colar

V - Ãr wâay aa ked rẽ

1PS ver DET colar

$\mathrm{S}$ - ̃̂r wâay aa ked rẽ

1PS ver DET colar

$\mathrm{P}$ - Ãr wâay aa ked rẽ

1PS ver DET colar

Contexto 3: indefinitude

Sentença (15): Eu vi uma mulher

V - Ãr wâay mẽe dâw ãy

1PS ver DET gente fêmea

$\mathrm{S}$ - Ãr wâay dâw ãy

1PS ver gente fêmea

$P$ - Ãr wâay mẽe dâw ãy

1PS ver DET gente fêmea

Sentença (16): Eu vi a Ana

$\mathrm{V}$ - Ãr wâay Ana-ũuy

1PS ver Ana-MDO

$S$ - Ãr wâay Ana-ũuy

1PS ver Ana-MDO

$\mathrm{P}$ - Ãr wâay Dâw ta'-ũuy

1PS ver gente Ana(?)-MDO

Sentença (17): Eu vi ela

V - Ãr wâay tir-ũuy’

1PS ver 3PS-MDO

S - Ãr wâay tirũuy'

1PS ver 3PS-MDO

P - Ãr wâay tirũuy'

1PS ver 3PS-MDO 
Sentença (18): Eu vi uma anta

$\mathrm{V}$ - ̃̃r wâay mẽe taax uy

1PS ver DET anta?

$\mathrm{S}-\tilde{A} \mathrm{r}$ wâay mẽe taax

1PS ver DET anta

$\mathrm{P}-\tilde{A} \mathrm{r}$ wâay mẽe taax

1PS ver DET anta

Sentença (19): Eu vi um colar

$\mathrm{V}$ - ̃̂r wâay mẽe ked rẽ

1PS ver DET colar

$S$ - Ãr wâay mẽe ked rẽ

1PS ver DET colar

$\mathrm{P}$ - ̃̂r wâay mẽe ked rẽ

1PS ver DET colar

No contexto 1, os dados dos três informantes testados mostrou-nos que nomes próprios e pronomes, objetos da categoria humano animado, sempre são marcados. No entanto, houve variação na marcação de nomes comuns como 'mulher' (sentença 1). O informante $\mathrm{V}$ marcou o objeto, diferentemente de $\mathrm{S}$ e $\mathrm{P}$ que não marcaram. Esse resultado pode ser caracterizado como um erro do informante $\mathrm{V}$.

Objetos na categoria nome animal animado apresentaram variação quanto ao uso de $\left\{-\tilde{u} u y y^{\prime}\right\}$. Tanto nomes comuns de animais (sentença 4), quanto nomes precedidos por determinante (sentença 5), variaram no uso do morfema de objeto. Objetos inanimados, por sua vez, não foram marcados, mesmo quando antecedidos por um determinante (sentenças 6 e 7).

No contexto 2, tanto nomes comuns, quanto próprios e pronomes foram marcados por $\{-\tilde{u} u y$ '\} pelos três informantes testados (sentenças 8,9 e 10). Objetos na categoria animal animado apresentaram novamente variação quanto ao uso de $\left\{-\tilde{u} u y^{\prime}\right\}$, tanto no seu uso como nome comum, quanto antecedido por determinante (sentenças 11 e 12). Objetos inanimados, por sua vez, novamente não foram marcados em nenhum cenário formulado (sentenças 13 e 14).

No contexto 3, nomes comuns como 'mulher' não foram marcados por nenhum informante (sentença 15). Já nomes próprios e pronomes foram marcados por todos os 
informantes testados (sentenças 16 e 17). Isso parece indicar que há uma hierarquização de marcação dentro da categoria humano animado. Nomes próprios são definidos e nomes comuns nem sempre o são. Ainda há vários pontos para investigar nesse cenário, como, por exemplo, a relação interna entre os fatores semânticos como animacidade, definitude e especificidade. Acreditamos que esses parâmetros semânticos não agem isoladamente, mas há um cruzamento de traços semânticos entre os próprios parâmetros, o que gera diferentes cenários de marcação. Pretendemos resolver essas questões em trabalhos futuros.

Objetos da categoria animal animado e inanimado não foram marcados por nenhum informante nesse contexto (sentença 19).

\section{ii) Elicitação com colocação de figuras e explanação de ações}

O teste linguístico de colocação de figuras e explanação de ações foi aplicado com três informantes, os mesmos do teste anterior: V, S e P. Organizamos o teste em três etapas:

- $\quad 1^{a}$ Etapa - colocação de figuras e explanação das ações: mostramos duas figuras para cada informante.

- $2^{a}$ Etapa - escolha das figuras: pedimos ao informante para escolher uma das figuras.

- $\quad 3^{a}$ Etapa - produção da sentença: pedimos ao informante para dizer qual das duas figuras ele escolheu. Para tanto, ele deveria usar uma sentença de controle: $\tilde{A} r$ tuk $X$ 'Eu quero $\mathrm{X}$ ', sendo $\mathrm{X}$ a figura que ele escolheu. $\mathrm{O}$ uso da sentença de controle foi importante para que o falante produzisse apenas sentenças transitivas nas quais o objeto da figura escolhida correspondesse ao objeto da sentença.

O objetivo do teste foi apresentar um contexto de definitude, uma vez que o falante deveria escolher entre duas figuras definidas e específicas pelo contexto de elicitação. As figuras foram organizadas em três categorias: objeto humano animado, objeto animal animado e objeto inanimado. Apresentamos exemplos das figuras utilizadas no teste. 


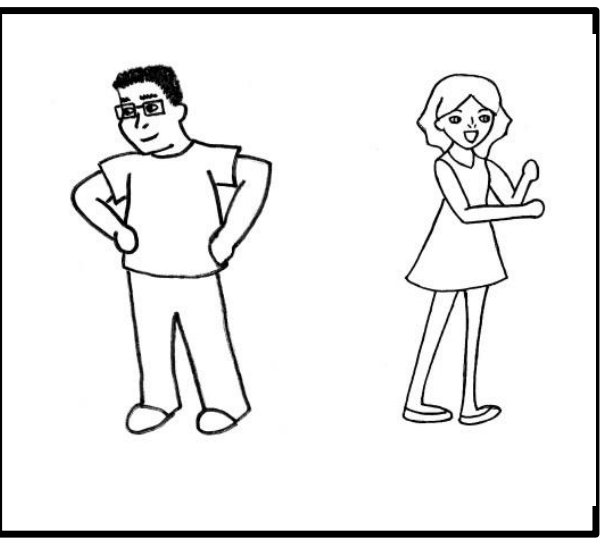

Figura 7.0: exemplo de objeto humano animado

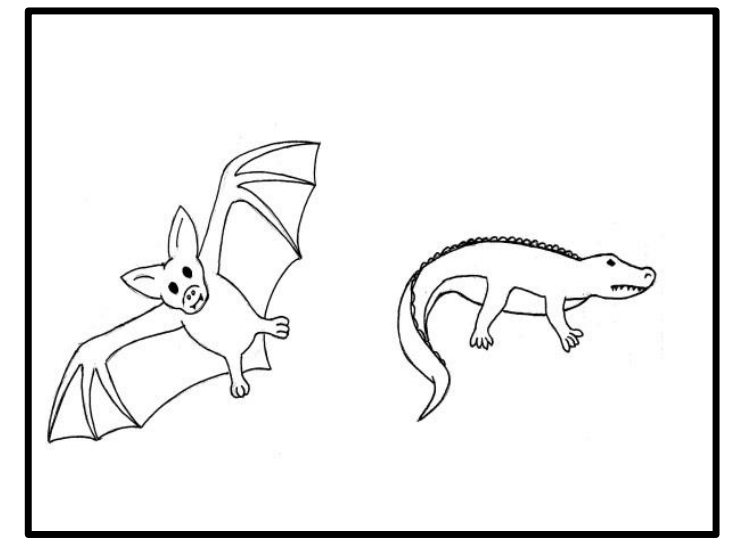

Figura 7.1: exemplo de objeto animal animado

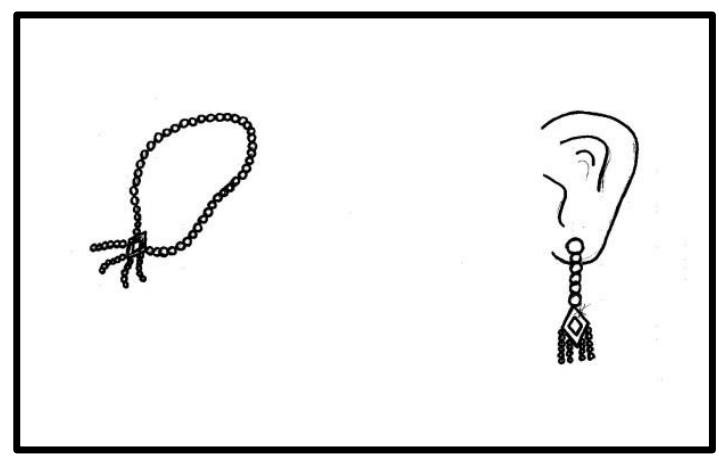

Figura 7.2: exemplo de objeto inanimado

Apresentamos os contextos de escolha das figuras utilizados no teste.

\begin{tabular}{c|l}
\hline Número & \multicolumn{1}{c}{ Contexto } \\
\hline 1 & $\begin{array}{l}\text { Aqui está a Jéssica e aqui está a Luciana. Escolha uma das duas e diga qual } \\
\text { você escolheu. }\end{array}$ \\
\hline 2 & $\begin{array}{l}\text { Aqui tem o Wallace e aqui a Luciana. Escolha um dos dois e diga qual você } \\
\text { escolheu. }\end{array}$ \\
\hline 3 & $\begin{array}{l}\text { Aqui tem um homem e aqui tem a Luciana. Escolha um dos dois e diga qual } \\
\text { você escolheu. }\end{array}$ \\
\hline 4 & $\begin{array}{l}\text { Aqui tem um homem e aqui uma mulher. Escolha um dos dois e diga qual } \\
\text { você escolheu. }\end{array}$ \\
\hline 5 & $\begin{array}{l}\text { Aqui tem a Luciana e aqui tem o Wallace. Escolha um dos dois e diga qual } \\
\text { você escolheu. }\end{array}$ \\
\hline 7 & $\begin{array}{l}\text { Aqui tem o tatu e aqui a anta. Escolha um dos dois e diga qual você } \\
\text { escolheu. }\end{array}$ \\
\hline 9 & $\begin{array}{l}\text { Aqui tem o jacaré e aqui o morcego. Escolha um dos dois e diga qual você } \\
\text { escolheu. }\end{array}$ \\
\hline $\begin{array}{l}\text { Aqui tem o morcego e aqui tem a anta. Escolha um dos dois e diga qual } \\
\text { você escolheu. }\end{array}$ \\
\hline 10 & $\begin{array}{l}\text { Aqui tem a onça e aqui tem a cobra. Escolha uma das duas e diga qual você } \\
\text { escolheu. }\end{array}$ \\
\hline $\begin{array}{l}\text { Aqui tem o macaco e aqui tem o tatu. Escolha um dos dois e diga qual você } \\
\text { escolheu. }\end{array}$ \\
\hline Aqui tem a onça e aqui tem o jacaré. Escolha um dos dois e diga qual você
\end{tabular}




\begin{tabular}{|c|c|}
\hline & olheu. \\
\hline 12 & $\begin{array}{l}\text { Aqui tem o macaco e aqui tem o morcego. Escolha um dos dois e diga qual } \\
\text { você escolheu. }\end{array}$ \\
\hline 13 & $\begin{array}{l}\text { Aqui tem o tatu e aqui tem a onça. Escolha um dos dois e diga qual você } \\
\text { escolheu. }\end{array}$ \\
\hline 14 & $\begin{array}{l}\text { Aqui tem o jacaré e aqui tem o morcego. Escolha um dos dois e diga qual } \\
\text { você escolheu. }\end{array}$ \\
\hline 15 & $\begin{array}{l}\text { Aqui tem o colar e aqui tem o brinco. Escolha um dos dois e diga qual você } \\
\text { escolheu. }\end{array}$ \\
\hline 16 & $\begin{array}{l}\text { Aqui tem o milho e aqui tem a fruta. Escolha um dos dois e diga qual você } \\
\text { escolheu. }\end{array}$ \\
\hline 17 & $\begin{array}{l}\text { Aqui tem o milho e aqui a macaxeira. Escolha um dos dois e diga qual você } \\
\text { escolheu. }\end{array}$ \\
\hline 18 & $\begin{array}{l}\text { Aqui tem a rede e aqui tem o colar. Escolha um dos dois e diga qual você } \\
\text { escolheu }\end{array}$ \\
\hline 19 & $\begin{array}{l}\text { Aqui tem a carne e aqui tem a fruta. Escolha uma das duas e diga qual você } \\
\text { escolheu. }\end{array}$ \\
\hline 20 & $\begin{array}{l}\text { Aqui tem a roupa e aqui tem a rede. Escolha uma das duas e diga qual você } \\
\text { escolheu. }\end{array}$ \\
\hline 21 & $\begin{array}{l}\text { Aqui tem a casa e aqui tem a rede. Escolha uma das duas e diga qual você } \\
\text { escolheu. }\end{array}$ \\
\hline 22 & $\begin{array}{l}\text { Aqui tem uma casa e aqui tem um colar. Escolha uma das duas e diga qual } \\
\text { dos dois você escolheu }\end{array}$ \\
\hline 23 & $\begin{array}{l}\text { Aqui tem o colar e aqui tem a anta. Escolha uma das duas e diga qual você } \\
\text { escolheu. }\end{array}$ \\
\hline 24 & $\begin{array}{l}\text { Aqui tem a Jéssica e aqui tem a onça. Escolha uma das duas e diga qual } \\
\text { você escolheu. }\end{array}$ \\
\hline
\end{tabular}

Tabela 7.4: Protocolo de elicitação com colocação de figuras e explanação de ações

Cinco contextos foram criados para a categoria objeto humano animado (contextos de 1 a 5); oito para a categoria objeto animal animado (contextos de 6 a 14); oito para a categoria inanimado (contextos de 15 a 22) e dois contextos foram mistos (escolha entre um objeto inanimado e animado - contexto 23 - e humano animado e animal animado - contexto 24).

As sentenças produzidas pelos três informantes encontram-se no Anexo 3 do presente trabalho.

A seguir, apresentamos os resultados quantitativos dos testes aplicados: 


\section{CATEGORIA DO OBJETO: HUMANO ANIMADO}

\begin{tabular}{c|c|c|c}
\hline \multirow{2}{*}{$\begin{array}{c}\text { Produção de } \\
\text { sentenças }\end{array}$} & $\mathbf{V}$ & $\mathbf{S}$ & $\mathbf{P}$ \\
\cline { 2 - 4 } & 5 & 6 & 6 \\
\hline $\begin{array}{c}\text { Total de sentenças } \\
\text { produzidas }\end{array}$ & & 6 & 6 \\
\hline $\begin{array}{c}\text { Marcados por } \\
\text { \{-utuy'\} }\end{array}$ & 5 & $100 \%$ & $100 \%$ \\
\hline
\end{tabular}

CATEGORIA DO OBJETO: ANIMAL ANIMADO

\begin{tabular}{c|c|c|c}
\hline \multirow{2}{*}{$\begin{array}{c}\text { Produção de } \\
\text { sentenças }\end{array}$} & $\mathbf{3}$ & $\mathbf{S}$ & $\mathbf{P}$ \\
\cline { 2 - 4 } & 9 & 9 & 11 \\
\hline $\begin{array}{c}\text { Total de sentenças } \\
\text { produzidas }\end{array}$ & & & 11 \\
\hline $\begin{array}{c}\text { Marcados por } \\
\text { \{-utuy'\} }\end{array}$ & 7 & 7 & $100 \%$ \\
\hline
\end{tabular}

CATEGORIA DO OBJETO: ANIMADO INANIMADO

\begin{tabular}{c|c|c|c}
\hline \multirow{2}{*}{$\begin{array}{c}\text { Produção de } \\
\text { sentenças }\end{array}$} & $\mathbf{3}$ & $\mathbf{S}$ & $\mathbf{P}$ \\
\cline { 2 - 4 } & 9 & 9 & 8 \\
\hline $\begin{array}{c}\text { Total de sentenças } \\
\text { produzidas }\end{array}$ & & & 5 \\
\hline $\begin{array}{c}\text { Marcados por } \\
\text { \{-üuy'\} }\end{array}$ & $33 \%$ & $44 \%$ & $62,5 \%$ \\
\hline
\end{tabular}

Tabela 7.5: Resultados dos testes de colocação de figuras e explanação de ações

Todos os informantes marcaram $100 \%$ das sentenças transitivas cujo objeto encaixa-se na categoria humano animado. Isso nos mostra que nomes comuns de pessoas como 'mulher', 'homem'; e nomes próprios como 'Luciana' e 'Wallace' sempre são marcados por $\{-\tilde{u} z y '\}$ na língua Dâw.

Objetos na categoria animal animado apresentaram uma ligeira variação quanto à marcação de $\{-\tilde{u} u y$ '\}. Com dois dos informantes testados, de $100 \%$ das sentenças cujo objeto é um animal como 'anta' e 'morcego', 77\% tiveram seu objeto marcado pelo morfema supracitado. O terceiro informante, por sua vez, marcou o objeto animal animado em $100 \%$ das ocorrências. O que nos mostra que ainda há certa variação quanto à marcação de objetos nessa categoria de animacidade, o que vai ao encontro do que foi observado em línguas como Yuhup e Hup, em que nomes comuns de animais são opcionalmente marcados. Ainda é preciso identificar o motivo de tal opcionalidade na marcação desses tipos de argumentos. Em todo caso, vemos que a animacidade parece ser um fator decisivo para o uso de $\{-\tilde{t} u y '\}$, uma vez que, apesar de todos os 
objetos serem definidos pelo contexto de elicitação, houve variação na marcação do sufixo de acordo com a natureza semântica de animacidade dos objetos apresentados.

Objetos na categoria inanimado apresentaram uma baixa marcação, conforme esperado. $\mathrm{O}$ informante $\mathrm{V}$ teve $33 \%$ dos objetos marcados por $\{-\tilde{t} u y\}$, $\mathrm{S}$ teve $44 \%$ e $\mathrm{P}$ teve $62,5 \%$. Com relação à taxa percentual de marcação de objetos produzidos por $\mathrm{P}$, percebemos que ela está um pouco acima da taxa apresentada pelos demais informantes. Além disso, ela apresenta um índice relativamente alto, uma vez que corresponde a mais da metade das ocorrências. Todavia, a análise do perfil de marcação de objetos feita por $\mathrm{P}$ nos revela que esse informante, em específico, apresenta uma alta taxa de uso de $\{$ $\tilde{u} u y '\}$ - de 100\% nas duas categorias de objetos animados. Diante disso, acreditamos que $\mathrm{P}$ parece revelar uma preferência no uso de $\{-\tilde{u} u y$ ' $\}$ com objetos, em relação aos outros dois informantes. Ainda sim, tendo em vista o uso de $\{-\tilde{u} u y$ ' $\}$ feito por P nas três categorias estudadas, ainda é notável que a categoria menos marcada é objeto inanimado, o que continua evidenciando que objetos inanimados são menos marcados do que objetos animados.

\section{Elicitação de sentenças bitransitivas}

\section{i) Teste de (a)gramaticalidade}

O teste de (a)gramaticalidade de sentenças bitransitivas foi aplicado com dois informantes, V e S. Nesse teste, apresentamos aos informantes sentenças escritas em Dâw e pedimos para os informantes julgarem as sentenças como boas ou bem formadas (gramaticais) ou ruins ou mal formadas (agramaticais). Testamos três tipos de estruturas: i) sentenças defaut, isto é, sentenças bitransitivas declarativas com o objeto indireto sufixado por $\{-\tilde{u} z y$ '\}; ii) sentenças com objetos não marcados; iii) sentenças com objetos diretos sufixados por $\{-\tilde{u} z y\}\}$ A seguir, apresentamos o protocolo de elicitação. 


\begin{tabular}{|c|c|c|}
\hline Número & Estrutura da sentença & Tipo sentencial \\
\hline 1 & SV OD OIи̃uy' & Sentença declarativa \\
\hline 2 & SV OD OI & $\begin{array}{l}\text { Sentença declarativa sem }\left\{-\tilde{\mathbf{u}} \mathbf{u} \mathbf{y}^{\prime}\right\} \text { no } \\
\text { objeto indireto }\end{array}$ \\
\hline 3 & SV ODũuy' OI & $\begin{array}{l}\text { Sentença bitransitiva com }\{\text {-йuy' }\} \text { no } \\
\text { objeto direto }\end{array}$ \\
\hline
\end{tabular}

Tabela 7.6: Protocolo de elicitação do teste de (a)gramaticalidade do uso de \{-zuty'\} com sentenças bitransitivas

O morfema $\{-\tilde{u} u y$ '\} é obrigatório com objetos indiretos, como podemos observar pela agramaticalidade gerada quando o morfema é suprimido do objeto indireto, vide sentença (20) e (21) abaixo. Todavia, de forma distinta ao que observamos nas outras duas línguas Nadahup analisadas, a marca de objeto não pode ocorrer com objetos diretos em sentenças com verbos bitransitivos, como podemos perceber pela agramaticalidade gerada pela marcação do objeto direto por $\{-\tilde{u} z y$ '\} em (22).
Dâw xut nõo weéd dâw tee-ũuy' gente macho dar comida gente filho-OBL
'O homem deu comida para a criança'

$\begin{array}{llllll}\text { * Dâw } & \text { xut } & \text { nõo } & \text { weéd } & \text { dâw } & \text { Tee } \\ \text { gente } & \text { macho } & \text { dar } & \text { comida } & \text { gente } & \text { Filho }\end{array}$

$\begin{array}{llllll}\text { * Dâw } & \text { xut } & \text { nõo } & \text { weéd-ũuy' } & \text { dâw } & \text { tee } \\ \text { gente } & \text { macho } & \text { dar } & \text { comida-OBL } & \text { gente } & \text { filho }\end{array}$

\subsection{Redefinindo caso afetado em Dâw}

Tendo em vista o padrão apresentado nos dados coletados, acreditamos que nomes definidos, específicos e animados são preferencialmente marcados por $\{-\tilde{u} u y\}, o$ que acreditamos ser uma evidência de que Dâw tenha MDO, à semelhança do que foi estudado nas línguas Yuhup e Hup. Ainda é necessário investigar a hierarquia (ou se há uma hierarquia) entre os traços semânticos citados.

Como pôde ser visto nos resultados dos testes, apesar do percentual baixo, nomes inanimados foram marcados em contextos de definitude (como visto no teste de colocação de figuras e explanação de ações). Todavia, nomes comuns na categoria 
humano animado não foram marcados em contexto de indefinitude e nãoespecificidade. Assim, ainda é necessário investigar a correlação entre os traços semânticos na marcação de objetos.

Além disso, acreditamos que a marcação de objeto em Dâw também pode estar associada a fatores extralinguísticos, como idade e classe social. No entanto, pretendemos explorar essa, entre outras questões, em trabalhos futuros.

Com relação à natureza estrutural do morfema $\{-\tilde{\mathbf{u}} \mathbf{u y}\}$, acreditamos que em sentenças bitransitivas o morfema supracitado, que ocorre somente com objetos indiretos, é morfema oblíquo, uma vez que nesses contextos, o atribuidor de caso é o morfema posposicionado ao constituinte marcado, e não o verbo. Objetos diretos não podem ser marcados por $\{-\tilde{u} u y\}$, possivelmente por possuírem Caso acusativo inerente.

\subsection{Síntese do capítulo}

Nesse capítulo, apresentamos a marca de objeto $\{-\tilde{u} z y$ ' $\}$ analisada por Martins (2004) como caso afetado, e analisada, neste trabalho, como MDO. Vimos que essa marca ocorre com objetos diretos de sentenças transitivas e sua aplicação está condicionada a restrições semânticas de definitude e animacidade. Por fim, vimos que Yuhup e Hup também possuem MDO em seu sistema. Nessas línguas, a MDO aparece com objetos diretos de sentenças transitivas e o morfema oblíquo, de forma homófona, ocorre com objetos indiretos de sentenças bitransitivas. 


\section{Considerações Finais}

Neste trabalho, estudamos as classes verbais da língua Dâw do ponto de vista semântico e sintático, identificando classes e subclasses de acordo com o comportamento morfossintático das raízes verbais.

Esta pesquisa tem como arcabouço teórico a teoria de estrutura argumental desenvolvida por Hale \& Keyser (2002), que propõe uma análise da sintaxe e da semântica dos itens lexicais por meio da estrutura argumental - sistema de relações estruturais estabelecidas entre o núcleo e seus argumentos (especificador e complemento) dentro de estruturas sintáticas projetadas pelo próprio núcleo (um predicador).

Além disso, procuramos apresentar e dialogar com algumas propostas teóricas que nos ajudassem a entender os dados coletados da língua Dâw. Entre essas propostas, destacam-se Maldonado (2006, 2007) e Kemmer (1993, 1994). A introdução dessas teorias funcionalistas se justifica na medida em que elas abordam fenômenos semânticos e tipológicos relacionados aos processos de intransitivização que estudamos em Dâw, e que não são abordadas na teoria de Hale \& Keyser (2002).

Ademais, também salientamos a importância de estudos como o de Aissen (2003) e Bossong (1999), literatura essencial para o entendimento do fenômeno de MDO, também abordado nesse trabalho.

Com relação aos resultados da pesquisa, apresentamos nossa proposta de reclassificação das classes verbais da língua Dâw. Martins (2004) classifica os verbos em Dâw em nove classes verbais, a saber: verbos ativos intransitivos, transitivos e bitransitivos; verbos de processo, verbos estativos equativos identificacionais e existenciais; verbos estativos descritivos atributivos, qualificativos e posicionais. Por meio de testes linguísticos variados, incluindo alternância de valência e julgamento de (a)gramaticalidade, mostramos que é possível simplificar essa classificação de Martins (2004) e reagrupar esses verbos em três classes verbais de acordo com a valência do verbo: classe dos verbos intransitivos (verbos intransitivos de processo, estativos equativos (e suas subclasses) e estativos descritivos (e suas subclasses); classe dos verbos transitivos e classe dos verbos bitransitivos.

Cada classe verbal apresentada mostrou padrões sintáticos e morfológicos específicos que nos possibilitaram realizar essa reclassificação. De modo geral, verbos 
intransitivos não podem ser predicados de sentenças reflexivas e não ocorrem com morfema de aspecto pontual dâr, mas ocorrem com o morfema de aspecto durativo xâd. É possível identificar uma subclasse de verbos alternantes - isto é, que alternam livremente entre uma forma incoativa e causativa - e verbos não-alternantes. Além disso, os predicados analisados por Martins (2004) como verbos estativos descritivos são adjetivos na língua. A verbalização do sintagma adjetival ocorre por meio de uma cópula (rãm 'ficar') que toma como complemento o adjetivo. Todos os verbos podem ser causativizados pelo causativizador dôo 'fazer'.

Verbos transitivos podem ocorrer com o dâr, mas não ocorrem com xâd. Formam sentenças reflexivas e não possuem restrições quanto à causativização com o causativizador dôo.

O único verbo bitransitivo em Dâw encontrado nesse trabalho foi o verbo nõo 'dar'. Os outros verbos bitransitivos apresentados em Martins (2004) não foram identificados e nem produzidos pelos falantes testados.

Também apresentamos e discutimos o sistema tonal da língua Dâw e a sua relação com o processo de transitivização e intransitivização. Contrapusemos a análise de Martins (2004) acerca do sistema tonal e do processo de transitivização e intransitivização em Dâw com os dados coletados em trabalho de campo e analisados por Storto, Costa e Andrade (em elaboração) e, contrariamente ao afirmado por Martins (2004), mostramos que o sistema tonal da língua Dâw, no nível da sentença, é previsível e que os tons dos itens lexicais de uma sentença neutralizam-se e passam a ser pronunciados de acordo com padrões tonais previsíveis. Desse modo, independentemente do processo de aumento ou diminuição de valência envolvido, percebemos que a mudança tonal dos verbos ocorre devido ao fraseamento fonológico das sentenças e não à presença de um morfema tonal transitivizador.

A transitivização em Dâw não ocorre por meio de morfemas explícitos. Desse modo, o processo de aumento de valência em questão é do tipo lábil, no qual a mesma raiz verbal é encontrada em sentenças intransitivas e causativas sem adição de morfologia em qualquer uma das formas. Ainda com relação ao processo de transitivização, demonstramos que as restrições de alternância de alguns verbos intransitivos devem-se à estrutura argumental de cada tipo verbal. No caso dos verbos intransitivos alternantes ou inacusativos, observamos que eles são formados a partir de estrutura diádica composta, que projeta um especificador interno e um complemento, o que lhe permite alternar entre uma forma intransitiva e transitiva. No caso dos verbos 
denominais e inergativos, percebemos que eles são formados a partir de uma estrutura argumental monádica, que não projeta especificador interno, o que impede a alternância. Verbos inacusativos não-alternantes são formados a partir de uma estrutura monádica que toma como complemento uma estrutura diádica básica, que projeta um argumento interno. Verbos desse tipo não alternam, pois eles não são formados por uma estrutura diádica, mas contêm uma estrutura desse tipo. Com relação aos verbos 'deadjetivais', vimos que eles são formados a partir de uma cópula que toma como complemento um adjetivo. Dessa forma, uma vez que raiz e núcleo verbal possuem conteúdo fonológico pleno (não vazio), não é possível fazer conflation entre núcleo e raiz, o que impede que o predicado verbal seja formado. Essa estrutura explica a agramaticalidade desses verbos frente ao processo de transitivização automática.

Com relação à causativização, ou transitivização complexa, vimos que há em Dâw um causativizador, isto é, dôo 'fazer', que adiciona ao predicado verbal, tanto intransitivo quanto transitivo, um argumento externo. Não há restrições de valência verbal quanto à causativização com esse auxiliar.

As análises acerca dos processos de intransitivização em Dâw mostraram que não há morfologia específica para a construção de sentenças médias, incoativas ou anticausativas e não existem passivas na língua em estudo. No lugar dessa voz, os falantes produzem sentenças incoativas ou com o sujeito subespecificado. Por fim, as sentenças reflexivas são geradas por meio de pronomes reflexivos na posição de objeto da sentença.

Por fim, com relação à MDO, vimos que essa marca ocorre com objetos diretos de sentenças transitivas e sua aplicação está condicionada a restrições semânticas de definitude e animacidade. Vimos também que em Yuhup e Hup (línguas da família Nadahup) também possuem MDO em seu sistema. Nessas línguas, a MDO aparece com objetos diretos de sentenças transitivas e o morfema oblíquo, de forma homófona, ocorre com objetos indiretos de sentenças bitransitivas.

Desse modo, os dados elicitados e apresentados nesta dissertação e as análises propostas para os fenômenos relacionados às classes verbais da língua Dâw foram basilares para alcançar o objetivo deste trabalho, que, como já mencionamos, foi o de estudar as classes verbais e a estrutura argumental da língua Dâw. Assim, consideramos que as discussões presentes neste trabalho contribuíram para o avanço do conhecimento sobre as línguas indígenas da família Nadahup, mais especificamente da língua Dâw, que até então, não havia sido estudada sob o viés teórico utilizado nessa pesquisa. 


\section{Referências Bibliográficas}

AIKHENVALD, A.Y. The languages of the Amazon. New York: Oxford University Press. 2012

AISSEN, J. "Differential object marking: iconicity vs. economy". In: Natural Language \& Linguistic Theory, vol. 21, n 3, p. 435-483, 2003

ASSIS, E. C. Patrões e Fregueses no Alto Rio Negro: As Relações de Dominação no Discurso do Povo Dâw. Amazonas: UFAM. Monografia, Instituto de Ciências Humanas e Letras. Curso de Ciências Sociais, Universidade Federal do Amazonas, 2001.

BOSSONG, G. "Differential Object Marking in Romance and Beyond". In: D. Wanner and D. Kibbee (eds.), New Analyses in Romance Linguistics: Selected Papers from the XVIII Linguistic Symposium on Romance Languages, Urbana - Champaign, Abril 7-9, 1988, John Benjamins, Amsterdam, p. 143-170, 1991.

BURZIO, L. Italian Syntax. Dordrecht: Reidel.1986.

CAMPBELL, L \& GRONDONA, V. The Indigenous Languages of South America: A Comprehensive Guide. Walter de Gruyter: 2012.

CHOMSKY, N. Lectures on Government and Binding, Foris, Dordrecht, 1981. . The Minimalist Program. Cambridge, Mass.: MIT Press, 1995.

COGHILL, E. "Differential Object Marking in Neo-Aramaic". In: Linguistics, vol. 52, $\mathrm{n}^{\mathrm{o}} 2$, p. 335-364. 2014.

DAYLEY, J.P. "Voice in Tzutujil". In: NICHOLS J. \& WOODBURY A.C (eds.) Grammar inside and outside the clause: p. 192-226. Cambridge: Cambridge University Press: 1985. 
DIXON, R. M. W. \& AIKHENVALD, A. Y. Changing valency. Case studies in transitivity. Cambridge University Press, 2000.

EPPS, Patience. A grammar of Hup. Tese de doutorado. University of Virginia. Charlottesville, Virginia, 2005.

HASPELMATH, M. "Transitivity Alternations of the Anticausative Type". In: Universität zu Köln, Institut für Sprachwissenschaft. Arbeitspapier Nr. 5 (Neue Folge), 1987.

."More on the typology of inchoative/causative verb alternation". In: Bernard Comrie and Maria Polinsky (eds.) Causatives and Transitivity, 87120.Amsterdam: John Benjamins. 1993.

HALE, K.; KEYSER, S. J. Prolegomenon to a Theory of Argument Structure. Cambrigde: MIT Press, 2002.

IEMMOLO, G \& ARCODIA, G. "Differential Object Marking and identifiability of the referent: A study of Mandarin Chinese”. In: Linguistics, vol. 52, n 2, p. 315334, 2014.

JAEGGLI, O. “Passive”. Linguistic Inquiry v. 17. p. 587-633, 1986.

KEENAN, E. L. \& DRYER. M. "Passive in the World's Languages". In: Clause Structure, Language Typology and Syntactic Description. Cambridge University Press. 2007

KEMMER, S. The middle voice. Amsterdam/Philadelphia: John Benjamins, 1993. . "Middle voice, Transitivity and Events". In: FOX, B.; HOPPER, P. (Eds.) Voice form and function. Amsterdam/Philadelphia: John Benjamins. p. 179-230, 1994. 
LAZZARINI CYRINO, J. Notas sobre o sincretismo passivo-reflexivo entre as línguas e suas abordagens teóricas, (manuscrito).

LIMA, S. O. A Estrutura argumental dos verbos na língua Juruna (Yudja): da formação dos verbos para a análise das estruturas sintáticas. Dissertação de mestrado - Departamento de Linguística, Universidade de São Paulo, São Paulo, 2008.

LYONS, C. Definiteness. Cambridge: Cambridge University Press, 1999.

MALDONADO, R. A media voz: problemas conceptuales del clítico se. México: Universidad Nacional Autónoma de México, 2006.

MALDONADO, R. "Grammatical voice in Cognitive Grammar". In: GEERAERTS, D.; CUYCKENS, H. The Oxford handbook of Cognitive Linguistics. p. 829-868. Oxford: Oxford University Press, 2007.

MARTINS, S. Fonologia e gramática Dâw. Tomo I e II. Tese de doutorado. Universidade de Amsterdã. Amsterdã, 2004

MARTINS, V. Reconstrução do Proto-Maku Oriental. Tese de Doutorado. Universidade de Amsterdã. Amsterdã. 2005.

MARTINS, V. Similaridades entre os sistemas tonais Maku e Baniua - Arawak. Comunicação Oral no VII Congresso Internacional da ABRALIN, 2013.

MARTINS, V. \& MARTINS, S. "Maku”. In: DIXON, R. M. W. \& AIKHENVALD, A. Y. The Amazonian Languages. Cambridge: CUP. 1999.

MINUSSI, R. A relação entre Caso e definitude no Hebraico: O Construct State e a Marcação Diferencial de objeto. Dissertação de Mestrado - Faculdade de Filosofia, Letras e Ciências Humanas da Universidade de São Paulo, 2009. 
NESPOR, I. \& VOGEL, M. Prosodic Phonology. Berlin - New York: Mouton de Gruyter, 1986.

NOGUEIRA, A.F.S. Wajoro ẽmẽto: fonologia segmental e morfossintaxe verbal. Dissertação de mestrado - Departamento de Lingüística, Universidade de São Paulo, São Paulo, 2011.

OSPINA, B.A.M. Les structures élémentaires du Yuhup Maké, Langue de l'amazonie colombiebbe: morphologie et syntaxe. Tese de Doutorado. Universidade de Paris, 2002.

PERLMUTTER, D. "Impersonal passives and the unaccusative hypothesis," in J. Jaeger, A. C. Woodbury, and F. Ackerman (eds.), Proceedings of the Fourth Annual Meeting of the Berkeley Linguistics Society, Berkeley, CA: University of California, BLS, 157-89, 1978.

ROCHA, I. A estrutura argumental da língua Karitiana: desafios descritivos e teóricos. Dissertação de Mestrado - Departamento de Lingüística, Universidade de São Paulo, São Paulo, 2011.

SHIBATANI, M. "Passives and related constructions: a prototype analysis". Language. v. 61. P. 821-848, 1985.

STORTO, COSTA \& ANDRADE. Interação entoacional nos sintagmas da língua Dâw (em elaboração).

VIVANCO, K. Orações relativas em Karitiana: um estudo experimental. Dissertação de Mestrado. Departamento de Linguística - Universidade de São Paulo, São Paulo, 2014.

YEGHIAZARYAN, L. Sobre a interação da marcação de caso e a definitude no Armênio. São Paulo. Dissertação de Mestrado - Faculdade de Filosofia, Letras e Ciências Humanas da Universidade de São Paulo, 2005. 


\section{Banco de dados dos verbos em Dâw}

\begin{tabular}{|c|c|c|c|c|c|c|}
\hline & $\begin{array}{c}\text { Verbo } \\
\text { (Forma } \\
\text { fonética) }\end{array}$ & $\begin{array}{c}\text { Verbo } \\
\text { (Ortografia) }\end{array}$ & Tradução & Classe verbal $^{1}$ & Fonte & Padrão tonal \\
\hline 1 & $/ \mathrm{br} /$ & bâ & Derramar & Transitivo & $\begin{array}{l}\text { Martins } \\
(2004)\end{array}$ & Atonal \\
\hline 2 & /brh/ & bâr & Derramar & Intransitivo & $\begin{array}{l}\text { Martins } \\
(2004)\end{array}$ & Atonal \\
\hline 3 & /br̀̀d/ & bâad & Derramar & Transitivo & $\begin{array}{l}\text { Martins } \\
(2004)\end{array}$ & Descendente \\
\hline 4 & /brd/ & bâd & Derramar & $\begin{array}{l}\text { Intransitivo } \\
\text { (verbo de } \\
\text { processo) }\end{array}$ & $\begin{array}{l}\text { Martins } \\
(2004)\end{array}$ & Atonal \\
\hline 5 & $/ \mathrm{kr} / /$ & kâs & Morder & $\begin{array}{c}\text { Transitivo } \\
\text { (bitransitivo) }\end{array}$ & $\begin{array}{l}\text { Martins } \\
(2004)\end{array}$ & Atonal \\
\hline 6 & /wèd/ & weed & Comer & Transitivo & $\begin{array}{l}\text { Martins } \\
(2004)\end{array}$ & Descendente \\
\hline 7 & /jũt/ & yũt & Matar & $\begin{array}{l}\text { Transitivo e } \\
\text { bitransitivo }\end{array}$ & $\begin{array}{l}\text { Martins } \\
(2004)\end{array}$ & Atonal \\
\hline 8 & $/ \int \gamma /$ & sâ & Matar & Transitivo & $\begin{array}{l}\text { Martins } \\
(2004)\end{array}$ & Atonal \\
\hline 9 & /Rub/ & ub & Acordar & Intransitivo & $\begin{array}{l}\text { Martins } \\
(2004)\end{array}$ & Atonal \\
\hline 10 & /Rùb/ & 'utb & Acordar & Transitivo & $\begin{array}{l}\text { Martins } \\
(2004)\end{array}$ & Descendente \\
\hline 11 & /wùd/ & wutud & Chegar & Intransitivo & $\begin{array}{l}\text { Martins } \\
(2004) \\
\end{array}$ & Descendente \\
\hline 12 & $/ \mathrm{j} \gamma /$ & yâ & Chegar & Intransitivo & $\begin{array}{l}\text { Martins } \\
\text { (2004) }\end{array}$ & Atonal \\
\hline 13 & /wujir/ & wuyâ & Chegar & Intransitivo & $\begin{array}{l}\text { Martins } \\
(2004)\end{array}$ & Atonal \\
\hline 14 & /nz̃̃d $/$ & nẽd & Chegar & Intransitivo & $\begin{array}{l}\text { Martins } \\
(2004)\end{array}$ & Atonal \\
\hline 15 & /pét/ & pêet & Quebrar & Transitivo & $\begin{array}{l}\text { Martins } \\
(2004) \\
\end{array}$ & Ascendente \\
\hline 16 & /pet/ & pêt & Quebrar & $\begin{array}{c}\text { Intransitivo } \\
\text { (verbo de } \\
\text { processo) }\end{array}$ & $\begin{array}{l}\text { Martins } \\
(2004)\end{array}$ & Atonal \\
\hline 17 & /Jáx/ & saax & Quebrar & Transitivo & $\begin{array}{l}\text { Martins } \\
(2004)\end{array}$ & Ascendente \\
\hline 18 & /def/ & dês & $\begin{array}{l}\text { Quebrar } \\
\text { coisas } \\
\text { redondas }\end{array}$ & Não definido & $\begin{array}{l}\text { Martins } \\
(2004)\end{array}$ & Atonal \\
\hline 19 & /wox/ & wox & Quebrar & Não & Martins & Atonal \\
\hline
\end{tabular}

\footnotetext{
${ }^{1}$ Classe verbal proposta por Martins (2004).
} 


\begin{tabular}{|c|c|c|c|c|c|c|}
\hline & & & & $\begin{array}{c}\text { classificado por } \\
\text { Martins }\end{array}$ & (2004) & \\
\hline 20 & /Rכx/ & 'ox & Correr & Intransitivo & $\begin{array}{l}\text { Martins } \\
(2004)\end{array}$ & Atonal \\
\hline 21 & /wứt/ & wũt & $\begin{array}{l}\text { Correr } \\
\text { ligeiro }\end{array}$ & $\begin{array}{l}\text { Verbo de } \\
\text { movimento }\end{array}$ & $\begin{array}{l}\text { Martins } \\
(2004)\end{array}$ & Ascendente \\
\hline 22 & /bet/ & bêt & Ser listrado & $\begin{array}{c}\text { Verbo estativo } \\
\text { descritivo } \\
\text { atributivo } \\
\end{array}$ & $\begin{array}{l}\text { Martins } \\
\text { (2004) }\end{array}$ & Atonal \\
\hline 23 & /duj/ & duy & Estar sujo & $\begin{array}{c}\text { Verbo estativo } \\
\text { descritivo } \\
\text { qualificativo } \\
\end{array}$ & $\begin{array}{l}\text { Martins } \\
(2004)\end{array}$ & Atonal \\
\hline 24 & /dùj/ & duty & Estar sujo & $\begin{array}{l}\text { Intransitivo } \\
\text { transitivizado } \\
\text { (verbo de } \\
\text { processo) }\end{array}$ & $\begin{array}{l}\text { Martins } \\
(2004)\end{array}$ & Descendente \\
\hline 25 & /cik/ & çik & Estar sujo & $\begin{array}{l}\text { Intransitivo } \\
\text { (verbo de } \\
\text { processo) }\end{array}$ & $\begin{array}{l}\text { Martins } \\
\text { (2004) }\end{array}$ & Atonal \\
\hline 26 & $/ \mathrm{tr}^{\prime} \mathrm{w}^{2 /}$ & tâaw' & Sujar & Verbo Ativo & $\begin{array}{l}\text { Martins } \\
(2004)\end{array}$ & Descendente \\
\hline 27 & $/ \mathrm{m}^{2} \tilde{\varepsilon} \mathrm{n} /$ & m'ẽn & Ser curto & $\begin{array}{c}\text { Verbo estativo } \\
\text { descritivo } \\
\text { atributivo } \\
\end{array}$ & $\begin{array}{l}\text { Martins } \\
(2004)\end{array}$ & Atonal \\
\hline 28 & /bep/ & bêp & Ser curto & $\begin{array}{l}\text { Verbo estativo } \\
\text { descritivo } \\
\text { atributivo }\end{array}$ & $\begin{array}{l}\text { Martins } \\
(2004)\end{array}$ & Atonal \\
\hline 29 & /pغ̀m/ & peem & $\begin{array}{c}\text { Estar } \\
\text { sentado }\end{array}$ & $\begin{array}{c}\text { Verbo estativo } \\
\text { descritivo } \\
\text { posicional }\end{array}$ & $\begin{array}{l}\text { Martins } \\
(2004)\end{array}$ & Descendente \\
\hline 30 & /pغ̀m/ & peem & $\begin{array}{c}\text { Estar } \\
\text { sentado }\end{array}$ & $\begin{array}{l}\text { Verbo estativo } \\
\text { descritivo } \\
\text { posicional } \\
\text { transitivizado }\end{array}$ & $\begin{array}{c}\text { Martins } \\
\text { (2004) }\end{array}$ & Descendente \\
\hline 31 & /xog/ & xog & $\begin{array}{c}\text { Estar } \\
\text { sentado }\end{array}$ & $\begin{array}{c}\text { Verbo estativo } \\
\text { descritivo } \\
\text { posicional }\end{array}$ & $\begin{array}{c}\text { Martins } \\
(2004)\end{array}$ & Atonal \\
\hline 32 & $/ \sqrt{\mathrm{a}} /$ & sa & $\begin{array}{c}\text { Estar } \\
\text { sentado no } \\
\text { chão } \\
\end{array}$ & $\begin{array}{l}\text { Verbo de } \\
\text { posição }\end{array}$ & $\begin{array}{c}\text { Martins } \\
(2004)\end{array}$ & Atonal \\
\hline 33 & /nĩc xap/ & nĩç xanh & $\begin{array}{c}\text { Sentar com } \\
\text { a perna } \\
\text { encolhida } \\
\end{array}$ & $\begin{array}{l}\text { Verbo de } \\
\text { posição }\end{array}$ & $\begin{array}{l}\text { Martins } \\
(2004)\end{array}$ & Atonal \\
\hline 34 & $/ \int \tilde{\partial} w^{?} x a /$ & sõw' xa & $\begin{array}{l}\text { Sentar de } \\
\text { cócoras }\end{array}$ & $\begin{array}{c}\text { Verbo de } \\
\text { posição }\end{array}$ & $\begin{array}{c}\text { Martins } \\
(2004) \\
\end{array}$ & Atonal \\
\hline 35 & /cãk xa/ & çãk xa & $\begin{array}{l}\text { Sentar-se } \\
\text { com força }\end{array}$ & $\begin{array}{l}\text { Verbo de } \\
\text { posição }\end{array}$ & $\begin{array}{l}\text { Martins } \\
(2004) \\
\end{array}$ & Atonal \\
\hline 36 & /he xa/ & re xa & $\begin{array}{l}\text { Sentar-se } \\
\text { em cima de } \\
\text { alguma } \\
\text { coisa } \\
\end{array}$ & $\begin{array}{l}\text { Verbo de } \\
\text { posição }\end{array}$ & $\begin{array}{l}\text { Martins } \\
(2004)\end{array}$ & Atonal \\
\hline 37 & $/$ / a xa/ & sa xa & $\begin{array}{l}\text { Sentar por } \\
\text { longo }\end{array}$ & $\begin{array}{l}\text { Verbo de } \\
\text { posição }\end{array}$ & $\begin{array}{l}\text { Martins } \\
(2004) \\
\end{array}$ & Atonal \\
\hline
\end{tabular}




\begin{tabular}{|c|c|c|c|c|c|c|}
\hline & & & tempo & & & \\
\hline 38 & /h̃̃/ & rõ & Queimar & $\begin{array}{l}\text { Verbo de } \\
\text { Processo }\end{array}$ & $\begin{array}{l}\text { Martins } \\
(2004)\end{array}$ & Atonal \\
\hline 39 & /do?/ & dô & Queimar & Não informado & $\begin{array}{l}\text { Martins } \\
(2004)\end{array}$ & Atonal \\
\hline 40 & /xòj/ & xôoy & Queimar & Não informado & $\begin{array}{l}\text { Martins } \\
(2004)\end{array}$ & Descendente \\
\hline 41 & /jú?/ & yuu & Queimar & Não informado & $\begin{array}{l}\text { Martins } \\
(2004)\end{array}$ & Ascendente \\
\hline 42 & /bax/ & bax & Aparecer & $\begin{array}{l}\text { Verbo de } \\
\text { Processo }\end{array}$ & $\begin{array}{l}\text { Martins } \\
(2004)\end{array}$ & Atonal \\
\hline 43 & /báx/ & baax & Aparecer & $\begin{array}{c}\text { Verbo de } \\
\text { Processo } \\
\text { transitivizado } \\
\end{array}$ & $\begin{array}{l}\text { Martins } \\
(2004)\end{array}$ & Ascendente \\
\hline 44 & /han/ & ran & Aparecer & Não informado & $\begin{array}{c}\text { Martins } \\
(2004) \\
\end{array}$ & Atonal \\
\hline 45 & /hán/ & raan & $\begin{array}{c}\text { Aparecer } \\
\text { para avisar } \\
\text { sobre } \\
\text { alguma } \\
\text { coisa } \\
\end{array}$ & Não informado & $\begin{array}{l}\text { Martins } \\
(2004)\end{array}$ & Ascendente \\
\hline 46 & /jet/ & yêt & $\begin{array}{l}\text { Estar no } \\
\text { chão }\end{array}$ & $\begin{array}{c}\text { Verbo estativo } \\
\text { descritivo } \\
\text { posicional } \\
\end{array}$ & $\begin{array}{l}\text { Martins } \\
(2004)\end{array}$ & Atonal \\
\hline 47 & /jét/ & yêet & $\begin{array}{l}\text { Estar no } \\
\text { chão }\end{array}$ & $\begin{array}{l}\text { Verbo estativo } \\
\text { descritivo } \\
\text { posicional } \\
\text { transitivizado }\end{array}$ & $\begin{array}{l}\text { Martins } \\
(2004)\end{array}$ & Ascendente \\
\hline 48 & $/ \mathrm{tu} /$ & tu & $\begin{array}{l}\text { Estar no } \\
\text { chão }\end{array}$ & Não informado & $\begin{array}{l}\text { Martins } \\
(2004)\end{array}$ & Atonal \\
\hline 49 & /j?ét/ & y'êet & $\begin{array}{l}\text { Pôr alguma } \\
\text { coisa no } \\
\text { chão } \\
\end{array}$ & Verbo Ativo & $\begin{array}{l}\text { Martins } \\
(2004)\end{array}$ & Ascendente \\
\hline 50 & /mũh/ & mũr & $\begin{array}{c}\text { Estar } \\
\text { deitado } \\
\text { esticado na } \\
\text { rede } \\
\end{array}$ & $\begin{array}{c}\text { Verbos } \\
\text { estativos } \\
\text { descritivos } \\
\text { posicionais } \\
\end{array}$ & $\begin{array}{l}\text { Martins } \\
(2004)\end{array}$ & Atonal \\
\hline 51 & /ka?/ & $\mathrm{ka}$ & $\begin{array}{c}\text { Estar } \\
\text { suspenso; } \\
\text { estar } \\
\text { deitado na } \\
\text { rede } \\
\end{array}$ & $\begin{array}{c}\text { Verbos } \\
\text { estativos } \\
\text { descritivos } \\
\text { posicionais }\end{array}$ & $\begin{array}{l}\text { Martins } \\
(2004)\end{array}$ & Atonal \\
\hline 52 & /beg/ & bêg & Clarear & $\begin{array}{l}\text { Verbo de } \\
\text { processo }\end{array}$ & $\begin{array}{l}\text { Martins } \\
(2004)\end{array}$ & Atonal \\
\hline 53 & /bèg/ & bêeg & Clarear & $\begin{array}{l}\text { Verbo de } \\
\text { processo }\end{array}$ & $\begin{array}{l}\text { Martins } \\
(2004)\end{array}$ & Descendente \\
\hline 54 & /jam/ & yam & Dançar & Intransitivo & $\begin{array}{l}\text { Martins } \\
(2004)\end{array}$ & Atonal \\
\hline 55 & /nốP/ & nõo & Dar & Bitransitivo & $\begin{array}{l}\text { Martins } \\
(2004)\end{array}$ & Ascendente \\
\hline 56 & /jũmhũ/ & yũmrũ & Cantar & Intransitivo & $\begin{array}{l}\text { Trabalho } \\
\text { de } \\
\text { Campo I }\end{array}$ & Atonal \\
\hline
\end{tabular}




\begin{tabular}{|c|c|c|c|c|c|c|}
\hline 57 & /xa/ & $\mathrm{xa}$ & Cozinhar & Verbo Ativo & $\begin{array}{c}\text { Martins } \\
(2004)\end{array}$ & Atonal \\
\hline 58 & /hãm/ & rãm & Andar & $\begin{array}{l}\text { Verbo de } \\
\text { movimento }\end{array}$ & $\begin{array}{c}\text { Trabalho } \\
\text { de } \\
\text { Campo I }\end{array}$ & Atonal \\
\hline 59 & /ko?-xó?/ & ko'-xôo & $\begin{array}{c}\text { Andar } \\
\text { curvado }\end{array}$ & Verbo Ativo & $\begin{array}{c}\text { Martins } \\
(2004)\end{array}$ & Ascendente \\
\hline 60 & /xah/ & xar & $\begin{array}{c}\text { Andar, o } \\
\text { trocar das } \\
\text { pernas } \\
\text { (maneira) }\end{array}$ & $\begin{array}{l}\text { Verbo de } \\
\text { movimento }\end{array}$ & $\begin{array}{c}\text { Martins } \\
(2004)\end{array}$ & Atonal \\
\hline 61 & /אóx/ & sôox & $\begin{array}{c}\text { Andar } \\
\text { apoiado no } \\
\text { pau } \\
\text { (instrumen } \\
\text { to) } \\
\end{array}$ & $\begin{array}{l}\text { Verbo de } \\
\text { movimento }\end{array}$ & $\begin{array}{c}\text { Martins } \\
\text { (2004) }\end{array}$ & Ascendente \\
\hline 62 & /jén/ & y'êenh & $\begin{array}{c}\text { Andar } \\
\text { como pato } \\
\text { (maneira) }\end{array}$ & $\begin{array}{c}\text { Verbo de } \\
\text { movimento }\end{array}$ & $\begin{array}{c}\text { Martins } \\
(2004)\end{array}$ & Ascendente \\
\hline 63 & /Rew/ & 'êw & $\begin{array}{c}\text { Andar com } \\
\text { as pernas } \\
\text { abertas } \\
\text { (maneira) }\end{array}$ & $\begin{array}{c}\text { Verbo de } \\
\text { movimento }\end{array}$ & $\begin{array}{c}\text { Martins } \\
(2004)\end{array}$ & Atonal \\
\hline 64 & $/ \int \tilde{x} \mathrm{t} /$ & sõt & $\begin{array}{c}\text { Andar } \\
\text { debaixo de } \\
\text { chuva } \\
\text { (circunstân } \\
\text { cia) } \\
\end{array}$ & $\begin{array}{l}\text { Verbo de } \\
\text { movimento }\end{array}$ & $\begin{array}{c}\text { Martins } \\
\text { (2004) }\end{array}$ & Atonal \\
\hline 65 & /Sót/ & sôt & $\begin{array}{c}\text { Andar na } \\
\text { ponta dos } \\
\text { pés } \\
\text { (maneira) }\end{array}$ & $\begin{array}{c}\text { Verbo de } \\
\text { movimento }\end{array}$ & $\begin{array}{c}\text { Martins } \\
(2004)\end{array}$ & Ascendente \\
\hline 66 & $/ \mathrm{mem}^{2} /$ & mêm' & $\begin{array}{l}\text { Andar pela } \\
\text { primeira } \\
\text { vez } \\
\text { (circunstân } \\
\text { cia) }\end{array}$ & $\begin{array}{c}\text { Verbo de } \\
\text { movimento }\end{array}$ & $\begin{array}{c}\text { Martins } \\
\text { (2004) }\end{array}$ & Atonal \\
\hline 67 & /dùn/ & duun & $\begin{array}{c}\text { Andar } \\
\text { devagar ao } \\
\text { aprende a } \\
\text { andar } \\
\text { (maneira } \\
\text { /causa) }\end{array}$ & $\begin{array}{l}\text { Verbo de } \\
\text { movimento }\end{array}$ & $\begin{array}{c}\text { Martins } \\
\text { (2004) }\end{array}$ & Descendente \\
\hline 68 & /kũ/ & kũ & $\begin{array}{l}\text { Andar } \\
\text { devagar } \\
\text { para não } \\
\text { espantar } \\
\text { caça } \\
\text { (maneira } \\
\text { /causa) }\end{array}$ & $\begin{array}{l}\text { Verbo de } \\
\text { movimento }\end{array}$ & $\begin{array}{c}\text { Martins } \\
\text { (2004) }\end{array}$ & Atonal \\
\hline 69 & /jần/ & yãanh & $\begin{array}{c}\text { Andar } \\
\text { bêbado, } \\
\text { ziguezague }\end{array}$ & $\begin{array}{c}\text { Verbo de } \\
\text { movimento }\end{array}$ & $\begin{array}{c}\text { Martins } \\
\text { (2004) }\end{array}$ & Atonal \\
\hline
\end{tabular}




\begin{tabular}{|c|c|c|c|c|c|c|}
\hline & & & $\begin{array}{c}\text { ar } \\
\text { (maneira) }\end{array}$ & & & \\
\hline 70 & $/ \int \varepsilon \mathrm{f}-\mathrm{k} \tilde{\varepsilon} \mathrm{T} /$ & sej-kẽ' & $\begin{array}{l}\text { Andar num } \\
\text { só pé } \\
\text { (maneira) }\end{array}$ & $\begin{array}{l}\text { Verbo de } \\
\text { movimento }\end{array}$ & $\begin{array}{c}\text { Martins } \\
(2004)\end{array}$ & Atonal \\
\hline 71 & /Rew/ & ‘ew & $\begin{array}{l}\text { Andar } \\
\text { aleijado }\end{array}$ & & $\begin{array}{l}\text { Martins } \\
(2004)\end{array}$ & Atonal \\
\hline 72 & $/ \mathrm{j} \gamma /$ & yâ & Voltar & Verbo Ativo & $\begin{array}{c}\text { Martins } \\
(2004)\end{array}$ & Atonal \\
\hline 73 & /Ják/ & saak & Subir & Verbo Ativo & $\begin{array}{l}\text { Martins } \\
(2004) \\
\end{array}$ & Ascendente \\
\hline 74 & /wàn/ & waan & Perseguir & Verbo Ativo & $\begin{array}{l}\text { Martins } \\
(2004)\end{array}$ & Descendente \\
\hline 75 & $/ \mathrm{n} \tilde{\varepsilon} \mathrm{d} /$ & nẽd & Vir & Verbo Ativo & $\begin{array}{c}\text { Martins } \\
(2004)\end{array}$ & Atonal \\
\hline 76 & /xũm?/ & xũm' & $\begin{array}{c}\text { Fechar a } \\
\text { mão }\end{array}$ & Verbo Ativo & $\begin{array}{l}\text { Martins } \\
(2004)\end{array}$ & Atonal \\
\hline 77 & /xũ̀m/ & xũum & $\begin{array}{c}\text { Fechar } \\
\text { paneiro } \\
\text { com folhas }\end{array}$ & Verbo Ativo & $\begin{array}{l}\text { Martins } \\
(2004)\end{array}$ & Descendente \\
\hline 78 & /Jun? & stunh' & $\begin{array}{c}\text { Ser ou } \\
\text { estar } \\
\text { enrolado } \\
\text { (para fios) }\end{array}$ & Verbo estativo & $\begin{array}{c}\text { Martins } \\
(2004)\end{array}$ & Atonal \\
\hline 79 & /Runn'/ & 'tunh' & $\begin{array}{c}\text { Ser ou } \\
\text { estar } \\
\text { enrolado } \\
\text { (para fios) }\end{array}$ & Verbo estativo & $\begin{array}{l}\text { Martins } \\
(2004)\end{array}$ & Atonal \\
\hline 80 & $/$ punn $^{2} /$ & punh' & $\begin{array}{c}\text { Enrolar } \\
\text { algo, } \\
\text { rodear }\end{array}$ & Verbo Ativo & $\begin{array}{l}\text { Martins } \\
(2004)\end{array}$ & Atonal \\
\hline 81 & /lon?/ & lon' & $\begin{array}{l}\text { Enrolar; } \\
\text { recolher } \\
\text { linha de } \\
\text { pesca }\end{array}$ & $\begin{array}{c}\text { Verbo } \\
\text { transitivo }\end{array}$ & $\begin{array}{c}\text { Martins } \\
(2004)\end{array}$ & Atonal \\
\hline 82 & /wòb/ & wôob & $\begin{array}{l}\text { Colocar, } \\
\text { embarcar }\end{array}$ & Verbo Ativo & $\begin{array}{l}\text { Martins } \\
(2004)\end{array}$ & Descendente \\
\hline 83 & /w?òb/ & w'ôob & $\begin{array}{c}\text { Pôr ou } \\
\text { deixar } \\
\text { alguma } \\
\text { coisa em } \\
\text { cima }\end{array}$ & Verbo Ativo & $\begin{array}{l}\text { Martins } \\
(2004)\end{array}$ & Descendente \\
\hline 84 & /pan²/ & panh' & $\begin{array}{l}\text { Estar mole } \\
\text { como papa }\end{array}$ & Verbo estativo & $\begin{array}{l}\text { Martins } \\
(2004)\end{array}$ & Atonal \\
\hline 85 & /pãx/ & pãx & Estar caído & Verbo estativo & $\begin{array}{l}\text { Martins } \\
(2004)\end{array}$ & Atonal \\
\hline 86 & /xấc/ & xãaç & $\begin{array}{l}\text { Descascar } \\
\text { com a boca }\end{array}$ & Verbo Ativo & $\begin{array}{l}\text { Martins } \\
(2004)\end{array}$ & Ascendente \\
\hline 87 & $/ / \int \mathrm{it} /$ & siiy & $\begin{array}{l}\text { Descascar } \\
\text { cipó }\end{array}$ & Verbo Ativo & $\begin{array}{l}\text { Martins } \\
(2004)\end{array}$ & Descendente \\
\hline 88 & $/ \int \mathrm{Im}^{2} /$ & sĩm' & $\begin{array}{l}\text { Descascar } \\
\text { cipó }\end{array}$ & & $\begin{array}{l}\text { Martins } \\
(2004)\end{array}$ & Atonal \\
\hline 89 & $/ \int \mathrm{IIm}^{2} /$ & sĩm' & Descascar & Verbo Ativo & Martins & Atonal \\
\hline
\end{tabular}




\begin{tabular}{|c|c|c|c|c|c|c|}
\hline & & & $\begin{array}{c}\text { mandioca } \\
\text { mole }\end{array}$ & & (2004) & \\
\hline 90 & /lod/ & lod & $\begin{array}{c}\text { Descascar } \\
\text { naturalmen } \\
\text { te (ex. a } \\
\text { pele } \\
\text { descasca } \\
\text { por causa } \\
\text { do sol) } \\
\end{array}$ & $\begin{array}{c}\text { Verbo } \\
\text { Intransitivo }\end{array}$ & $\begin{array}{l}\text { Martins } \\
(2004)\end{array}$ & Atonal \\
\hline 91 & /lòd/ & lood & $\begin{array}{c}\text { Descascar } \\
\text { alguma } \\
\text { coisa (ex. } \\
\text { banana, } \\
\text { bola de } \\
\text { goma, etc.) }\end{array}$ & $\begin{array}{c}\text { Verbo } \\
\text { Transitivo }\end{array}$ & $\begin{array}{c}\text { Martins } \\
(2004)\end{array}$ & Descendente \\
\hline 92 & /lòd/ & lood & Assar goma & $\begin{array}{c}\text { Não } \\
\text { classificado por } \\
\text { Martins }\end{array}$ & $\begin{array}{l}\text { Martins } \\
\text { (2004) }\end{array}$ & Descendente \\
\hline 93 & /xep/ & xep & Descascar & Verbo estativo & $\begin{array}{c}\text { Martins } \\
(2004)\end{array}$ & Atonal \\
\hline 94 & /kob/ & kôb & Descascar & & $\begin{array}{l}\text { Martins } \\
(2004)\end{array}$ & Atonal \\
\hline 95 & /Rứn? / & 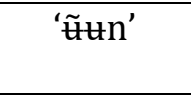 & $\begin{array}{l}\text { Olhar bem } \\
\text { rápido }\end{array}$ & Verbo Ativo & $\begin{array}{c}\text { Martins } \\
(2004) \\
\end{array}$ & Ascendente \\
\hline 96 & /pita/ & pita & Ficar & Verbo Ativo & $\begin{array}{c}\text { Martins } \\
(2004)\end{array}$ & Atonal \\
\hline 97 & /jawi/ & yawi & Errar & Verbo Ativo & $\begin{array}{c}\text { Martins } \\
(2004)\end{array}$ & Atonal \\
\hline 98 & /Rojal' $/$ & 'oyal' & Acreditar & Verbo Ativo & $\begin{array}{l}\text { Martins } \\
\text { (2004) }\end{array}$ & Atonal \\
\hline 99 & /pulah/ & pular & Sofrer & Verbo Ativo & $\begin{array}{l}\text { Martins } \\
(2004)\end{array}$ & Atonal \\
\hline 100 & /jeléw? & yêlêew' & $\begin{array}{c}\text { Transforma } \\
\text { r-se }\end{array}$ & Verbo Ativo & $\begin{array}{c}\text { Martins } \\
(2004)\end{array}$ & Ascendente \\
\hline 101 & /אã?ã/ & sã'ã & $\begin{array}{c}\text { Experiment } \\
\text { ar }\end{array}$ & Verbo Ativo & $\begin{array}{l}\text { Martins } \\
(2004)\end{array}$ & Atonal \\
\hline 102 & /do?oh/ & do'lor & $\begin{array}{l}\text { Pintar de } \\
\text { cor clara }\end{array}$ & Verbo Ativo & $\begin{array}{c}\text { Martins } \\
(2004) \\
\end{array}$ & Atonal \\
\hline 103 & /xũ̃น̃n? / & $x \tilde{u}^{\prime} \tilde{u} n^{\prime}$ & $\begin{array}{c}\text { Conversar, } \\
\text { papear }\end{array}$ & Verbo Ativo & $\begin{array}{l}\text { Martins } \\
(2004)\end{array}$ & Atonal \\
\hline 104 & /xũũ̃u/ & 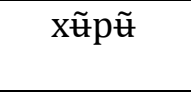 & $\begin{array}{l}\text { Ficar } \\
\text { exibido }\end{array}$ & Verbo Ativo & $\begin{array}{c}\text { Martins } \\
(2004) \\
\end{array}$ & Atonal \\
\hline 105 & /to?buk/ & tô'buk & Fechar & Verbo Ativo & $\begin{array}{l}\text { Martins } \\
(2004) \\
\end{array}$ & Atonal \\
\hline 106 & /jəmdã?/ & jomdã' & $\begin{array}{c}\text { Fazer vinho } \\
\text { de açaí }\end{array}$ & Verbo Ativo & $\begin{array}{c}\text { Martins } \\
(2004) \\
\end{array}$ & Atonal \\
\hline 107 & /kog?כ́́y/ & kô'õong & $\begin{array}{l}\text { Desmaiar- } \\
\text { se }\end{array}$ & Verbo Ativo & $\begin{array}{l}\text { Martins } \\
(2004)\end{array}$ & Ascendente \\
\hline 108 & /kog-?ร́w? & kôg-'õow’ & Desmaiar & Verbo Ativo & $\begin{array}{c}\text { Martins } \\
(2004) \\
\end{array}$ & Ascendente \\
\hline 109 & /jच̃m?eh/ & yẽe'er & Rezar & Verbo Ativo & $\begin{array}{c}\text { Martins } \\
(2004) \\
\end{array}$ & Atonal \\
\hline 110 & /mĩhjug/ & mĩryug & Misturar, & Verbo Ativo & Martins & Atonal \\
\hline
\end{tabular}




\begin{tabular}{|c|c|c|c|c|c|c|}
\hline & & & dissolver & & $(2004)$ & \\
\hline 111 & /do?-cah/ & do'-car & $\begin{array}{l}\text { Pintar de } \\
\text { preto }\end{array}$ & Verbo Ativo & $\begin{array}{c}\text { Martins } \\
(2004)\end{array}$ & Atonal \\
\hline 112 & /win?'-jrw/ & w'ing'-yâw & Cansar & Verbo Ativo & $\begin{array}{l}\text { Martins } \\
(2004)\end{array}$ & Atonal \\
\hline 113 & /nכิ́-jốh/ & nõo-yõor & Medicar & Verbo Ativo & $\begin{array}{l}\text { Martins } \\
(2004)\end{array}$ & Ascendente \\
\hline 114 & /tek-cax/ & têk-cax & $\begin{array}{c}\text { Barrear } \\
\text { (encher de } \\
\text { barro) }\end{array}$ & Verbo Ativo & $\begin{array}{l}\text { Martins } \\
\text { (2004) }\end{array}$ & Atonal \\
\hline 115 & /hãm-tu/ & rãm-tu & Rastejar & Verbo Ativo & $\begin{array}{l}\text { Martins } \\
(2004)\end{array}$ & Atonal \\
\hline 116 & /ñ̃h-ka/ & nõr-ka & Bocejar & Verbo Ativo & $\begin{array}{c}\text { Martins } \\
(2004)\end{array}$ & Atonal \\
\hline 117 & 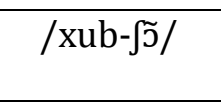 & xub-sõ & $\begin{array}{l}\text { Estar triste, } \\
\text { entristecer }\end{array}$ & Verbo Estativo & $\begin{array}{l}\text { Martins } \\
(2004)\end{array}$ & Atonal \\
\hline 118 & /ked-pif/ & ked-pij & Encher & Verbo Ativo & $\begin{array}{l}\text { Martins } \\
(2004)\end{array}$ & Atonal \\
\hline 119 & $/ \mathrm{k} \varepsilon \mathrm{d}-\mathrm{Ju} /$ & ked-su & $\begin{array}{c}\text { Tirar água } \\
\text { da canoa }\end{array}$ & Verbo Ativo & $\begin{array}{l}\text { Martins } \\
(2004)\end{array}$ & Atonal \\
\hline 120 & 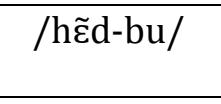 & rẽd-bu & $\begin{array}{c}\text { Envergonh } \\
\text { ar }\end{array}$ & Verbo Ativo & $\begin{array}{l}\text { Martins } \\
(2004)\end{array}$ & Atonal \\
\hline 121 & /we-kàn/ & we-kaan & Umedecer & Verbo Ativo & $\begin{array}{l}\text { Martins } \\
(2004)\end{array}$ & Descendente \\
\hline 122 & /wif-top/ & wis-top & Fazer tapiri & Verbo Ativo & $\begin{array}{l}\text { Martins } \\
(2004)\end{array}$ & Atonal \\
\hline 123 & /wirj-1a/ & w'ây'-'a & Gaguejar & Verbo Ativo & $\begin{array}{l}\text { Martins } \\
\text { (2004) }\end{array}$ & Atonal \\
\hline 124 & /peg-Ják/ & pêg-saak & Crescer & $\begin{array}{l}\text { Serialização } \\
\text { verbal } \\
\text { Verbos ativo }\end{array}$ & $\begin{array}{l}\text { Martins } \\
\text { (2004) }\end{array}$ & Atonal \\
\hline 125 & /buj-dó?/ & buy-doo' & $\begin{array}{l}\text { Ser recém- } \\
\text { casado }\end{array}$ & $\begin{array}{c}\text { Serialização } \\
\text { verbal } \\
\text { Verbo estativo }\end{array}$ & $\begin{array}{l}\text { Martins } \\
\text { (2004) }\end{array}$ & Descendente \\
\hline 126 & /be?-hãm/ & be'-rãm & $\begin{array}{c}\text { Enluarar, } \\
\text { tornar-se } \\
\text { enluarado } \\
\end{array}$ & $\begin{array}{c}\text { Serialização } \\
\text { verbal } \\
\text { Verbo estativo }\end{array}$ & $\begin{array}{c}\text { Martins } \\
(2004)\end{array}$ & Atonal \\
\hline 127 & /to?-peg/ & to'-pêg & $\begin{array}{c}\text { Encher a } \\
\text { barriga }\end{array}$ & Verbo Ativo & $\begin{array}{l}\text { Martins } \\
(2004) \\
\end{array}$ & Atonal \\
\hline 128 & /xub/ & xub & Dialogar & Verbo Ativo & $\begin{array}{l}\text { Martins } \\
(2004) \\
\end{array}$ & Atonal \\
\hline 129 & /mám²/ & maam' & Dialogar & Verbo Ativo & $\begin{array}{l}\text { Martins } \\
\text { (2004) }\end{array}$ & Ascendente \\
\hline 130 & $/ w^{i} \gamma j^{2} /$ & w'ây' & Dialogar & Verbo Ativo & $\begin{array}{l}\text { Martins } \\
(2004)\end{array}$ & Atonal \\
\hline 131 & /xup-wэc/ & xup-woç & Assustar-se & $\begin{array}{l}\text { Verbo de } \\
\text { processo }\end{array}$ & $\begin{array}{l}\text { Martins } \\
\text { (2004) }\end{array}$ & Atonal \\
\hline 132 & /xr?-kŕt/ & xâ'-kâat & Pisar & Verbo Ativo & $\begin{array}{l}\text { Martins } \\
(2004)\end{array}$ & Ascendente \\
\hline 133 & $/ x \gamma+\gamma /$ & xâjâ & Retornar & Verbo Ativo & $\begin{array}{c}\text { Martins } \\
\text { (2004) }\end{array}$ & Atonal \\
\hline 134 & /xũmũ/ & $x \tilde{u} m \tilde{u}$ & $\begin{array}{c}\text { Brigar uns } \\
\text { com os }\end{array}$ & $\begin{array}{l}\text { Verbo de } \\
\text { processo }\end{array}$ & $\begin{array}{l}\text { Martins } \\
(2004)\end{array}$ & Atonal \\
\hline
\end{tabular}




\begin{tabular}{|c|c|c|c|c|c|c|}
\hline & & & outros & & & \\
\hline 135 & /brjr/ & bâyâ & $\begin{array}{c}\text { Voltar de } \\
\text { novo }\end{array}$ & Verbo Ativo & $\begin{array}{l}\text { Martins } \\
(2004)\end{array}$ & Atonal \\
\hline 136 & /tamع̃h/ & tamẽr & $\begin{array}{c}\text { Ser } \\
\text { corajoso }\end{array}$ & Verbo Estativo & $\begin{array}{l}\text { Martins } \\
(2004)\end{array}$ & Atonal \\
\hline 137 & /hấm/ & rãam & Levar & Verbo Ativo & $\begin{array}{l}\text { Martins } \\
\text { (2004); }\end{array}$ & Ascendente \\
\hline 138 & $/ \mathrm{l} \gamma \mathrm{b} /$ & lâb & $\begin{array}{c}\text { Girar } \\
\text { sozinho } \\
\text { (ex. a bola } \\
\text { gira por } \\
\text { causa do } \\
\text { vento) }\end{array}$ & $\begin{array}{l}\text { Verbo Ativo - } \\
\text { Intransitivo }\end{array}$ & $\begin{array}{l}\text { Martins } \\
(2004)\end{array}$ & Atonal \\
\hline 139 & /lìrb/ & lâab & $\begin{array}{c}\text { Girar } \\
\text { alguma } \\
\text { coisa (ex. a } \\
\text { manivela } \\
\text { do motor) }\end{array}$ & $\begin{array}{l}\text { Verbo Ativo - } \\
\text { Transitivo }\end{array}$ & $\begin{array}{l}\text { Martins } \\
(2004)\end{array}$ & Descendente \\
\hline 140 & $/ \mathrm{m}^{2} \tilde{u} \mathrm{t} /$ & $\mathrm{m}^{\prime} \tilde{\mathrm{ut}}$ & $\begin{array}{c}\text { Ser } \\
\text { enrolado, } \\
\text { ser girado } \\
\text { (ex. tabaco } \\
\text { de rolo) } \\
\end{array}$ & Verbo Estativo & $\begin{array}{l}\text { Martins } \\
\text { (2004); }\end{array}$ & Atonal \\
\hline 141 & $/ \mathrm{m}^{2}$ ú́t/ & $\mathrm{m}^{\prime} \tilde{\mathrm{u} u t}$ & $\begin{array}{l}\text { Girar para } \\
\text { brocar; } \\
\text { criar uma } \\
\text { saliência } \\
\text { cônica }\end{array}$ & Verbo Ativo & $\begin{array}{l}\text { Martins } \\
(2004)\end{array}$ & Ascendente \\
\hline 142 & /wr? dó?/ & wâ'-dôo' & Obedecer & $\begin{array}{c}\text { Verbo } \\
\text { serializado }\end{array}$ & $\begin{array}{l}\text { Martins } \\
(2004)\end{array}$ & Ascendente \\
\hline 143 & /xóp bax/ & xôop bax & Boiar & $\begin{array}{c}\text { Verbo } \\
\text { serializado }\end{array}$ & $\begin{array}{l}\text { Martins } \\
(2004)\end{array}$ & Ascendente \\
\hline 144 & 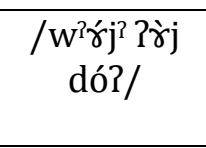 & w'âay' 'âay dôo' & Responder & $\begin{array}{c}\text { Verbo } \\
\text { serializado }\end{array}$ & $\begin{array}{l}\text { Martins } \\
(2004)\end{array}$ & $\begin{array}{c}\text { Construção } \\
\text { com mais de } \\
\text { um tom }\end{array}$ \\
\hline 145 & /wi'́rj j j’áh/ & w'âay' y'aar & Enganar & $\begin{array}{c}\text { Verbo } \\
\text { serializado }\end{array}$ & $\begin{array}{l}\text { Martins } \\
(2004)\end{array}$ & $\begin{array}{c}\text { Construção } \\
\text { com mais de } \\
\text { um tom }\end{array}$ \\
\hline 146 & /j?áh/ & y'aar & Enganar & $\begin{array}{c}\text { Verbo } \\
\text { composto }\end{array}$ & $\begin{array}{l}\text { Martins } \\
(2004)\end{array}$ & Ascendente \\
\hline 147 & /2ấx páh/ & ‘ãa paar & Perguntar & $\begin{array}{c}\text { Verbo } \\
\text { composto }\end{array}$ & $\begin{array}{l}\text { Martins } \\
\text { (2004) }\end{array}$ & $\begin{array}{c}\text { Construção } \\
\text { com mais de } \\
\text { um tom }\end{array}$ \\
\hline 148 & /jah jr/ & yar yâ & Trazer & $\begin{array}{c}\text { Verbo } \\
\text { composto }\end{array}$ & $\begin{array}{l}\text { Martins } \\
(2004) \\
\end{array}$ & Atonal \\
\hline 149 & /dó? píf/ & dôo' piis & Diminuir & $\begin{array}{c}\text { Verbo } \\
\text { composto }\end{array}$ & $\begin{array}{l}\text { Martins } \\
(2004)\end{array}$ & Ascendente \\
\hline 150 & /xrjr/ & xâyâ & Entrar & $\begin{array}{c}\text { Verbo } \\
\text { composto }\end{array}$ & $\begin{array}{l}\text { Martins } \\
(2004)\end{array}$ & Atonal \\
\hline 151 & /brjr/ & bâyâ & Regressar & $\begin{array}{c}\text { Verbo } \\
\text { composto }\end{array}$ & $\begin{array}{l}\text { Martins } \\
(2004) \\
\end{array}$ & Atonal \\
\hline 152 & /brj-xrd/ & bây-xâd & $\begin{array}{c}\text { Atravessar } \\
\text { de volta }\end{array}$ & $\begin{array}{c}\text { Verbo } \\
\text { composto }\end{array}$ & $\begin{array}{l}\text { Martins } \\
(2004)\end{array}$ & Atonal \\
\hline
\end{tabular}




\begin{tabular}{|c|c|c|c|c|c|c|}
\hline 153 & 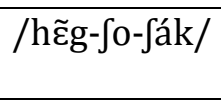 & rẽg-so-saak & Desmaiar & Verbo Ativo & $\begin{array}{c}\text { Martins } \\
(2004)\end{array}$ & Ascendente \\
\hline 154 & /hũ-?ã/ & rũ-'ã & $\begin{array}{c}\text { Fazer } \\
\text { caçada } \\
\text { (dormir na } \\
\text { mata para } \\
\text { caçar à } \\
\text { noite) }\end{array}$ & Verbo Ativo & $\begin{array}{c}\text { Martins } \\
\text { (2004) }\end{array}$ & Atonal \\
\hline 155 & /wr?-kŕt/ & wâ'-kâat & Pisar & Verbo Ativo & $\begin{array}{c}\text { Martins } \\
(2004) \\
\end{array}$ & Descendente \\
\hline 156 & 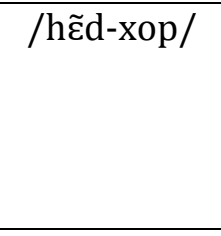 & rẽd-xôp & $\begin{array}{l}\text { Enxugar } \\
\text { (LIT. ser o } \\
\text { recipiente } \\
\text { do ato de } \\
\text { secar) }\end{array}$ & Verbo Ativo & $\begin{array}{c}\text { Martins } \\
\text { (2004) }\end{array}$ & Atonal \\
\hline 157 & 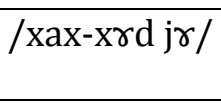 & xax-xâd yâ & Escolher & Verbo Ativo & $\begin{array}{c}\text { Martins } \\
(2004)\end{array}$ & Atonal \\
\hline 158 & /xub-jum/ & xub-yum & $\begin{array}{l}\text { Reestabele } \\
\text { cer a saúde }\end{array}$ & Verbo Ativo & $\begin{array}{c}\text { Martins } \\
(2004) \\
\end{array}$ & Atonal \\
\hline 159 & /mĩh-jug/ & mĩr-yug & $\begin{array}{l}\text { Misturar, } \\
\text { dissolver }\end{array}$ & Verbo Ativo & $\begin{array}{c}\text { Martins } \\
(2004)\end{array}$ & Atonal \\
\hline 160 & 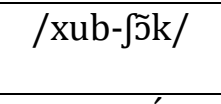 & xub-sõk & Estar triste & Verbo Estativo & $\begin{array}{c}\text { Martins } \\
(2004)\end{array}$ & Atonal \\
\hline 161 & /tuum-cấ?/ & tum-cãa' & Piscar & Verbo Ativo & $\begin{array}{c}\text { Martins } \\
(2004)\end{array}$ & Descendente \\
\hline 162 & /ked-pif/ & ked-pij & Encher & Verbo Ativo & $\begin{array}{c}\text { Martins } \\
(2004)\end{array}$ & Atonal \\
\hline 163 & /cè/ & çêe & $\begin{array}{l}\text { Espantar, } \\
\text { espalhar }\end{array}$ & Verbo Ativo & $\begin{array}{c}\text { Martins } \\
(2004) \\
\end{array}$ & Descendente \\
\hline 164 & /céh/ & çêer & Ir longe & Verbo Ativo & $\begin{array}{c}\text { Martins } \\
(2004) \\
\end{array}$ & Ascendente \\
\hline 165 & /ใù / & 'uu & $\begin{array}{c}\text { Carregar } \\
\text { nos braços }\end{array}$ & Verbo Ativo & $\begin{array}{c}\text { Martins } \\
(2004)\end{array}$ & Descendente \\
\hline 166 & /Rúh/ & 'uur & Ajudar & Verbo Ativo & $\begin{array}{c}\text { Martins } \\
(2004)\end{array}$ & Ascendente \\
\hline 167 & /cŕk/ & câak & Roubar & Verbo Ativo & $\begin{array}{c}\text { Martins } \\
(2004) \\
\end{array}$ & Ascendente \\
\hline 168 & /pah/ & par & Latir & Verbo Ativo & $\begin{array}{c}\text { Martins } \\
(2004) \\
\end{array}$ & Atonal \\
\hline 169 & /páh/ & paar & Saber & Verbo Ativo & $\begin{array}{c}\text { Martins } \\
(2004)\end{array}$ & Ascendente \\
\hline 170 & $/ \mathrm{tr}^{2} /$ & tâw' & Ser pesado & Verbo Ativo & $\begin{array}{c}\text { Martins } \\
(2004) \\
\end{array}$ & Atonal \\
\hline 171 & /tep/ & têp & Arrebentar & Verbo Ativo & $\begin{array}{c}\text { Martins } \\
(2004)\end{array}$ & Atonal \\
\hline 172 & /tép/ & têep & Cercar & Verbo Ativo & $\begin{array}{c}\text { Martins } \\
(2004)\end{array}$ & Ascendente \\
\hline 173 & $/ \mathrm{t} \tilde{\varepsilon} \mathrm{m}^{\mathrm{T} /}$ & tẽm' & $\begin{array}{c}\text { Embolorad } \\
0 \\
\end{array}$ & Verbo Ativo & $\begin{array}{c}\text { Martins } \\
(2004) \\
\end{array}$ & Atonal \\
\hline 174 & $/ \mathrm{t} \tilde{\varepsilon} \mathrm{m}^{2} /$ & tẽem' & $\begin{array}{c}\text { Virar } \\
\text { cabelo para } \\
\text { molhar } \\
\end{array}$ & Verbo Ativo & $\begin{array}{c}\text { Martins } \\
(2004)\end{array}$ & Ascendente \\
\hline 175 & /wuid/ & wud & Gritar bem & Verbo Ativo & Martins & Atonal \\
\hline
\end{tabular}


Anexos 1

\begin{tabular}{|c|c|c|c|c|c|c|}
\hline & & & alto & & $(2004)$ & \\
\hline 176 & /jah/ & yar & Buscar & Verbo Ativo & $\begin{array}{l}\text { Martins } \\
(2004)\end{array}$ & Atonal \\
\hline 177 & /jáh/ & yaar & $\begin{array}{l}\text { Agradar, } \\
\text { paparicar }\end{array}$ & Verbo Ativo & $\begin{array}{l}\text { Martins } \\
(2004)\end{array}$ & Ascendente \\
\hline 178 & /dák/ & daak & Colocar & $\begin{array}{c}\text { Verbo Ativo } \\
\text { Transitivo } \\
\end{array}$ & $\begin{array}{l}\text { Martins } \\
(2004) \\
\end{array}$ & Ascendente \\
\hline 179 & /dak/ & dak & $\begin{array}{l}\text { Colocar, } \\
\text { Pôr }\end{array}$ & Verbo Estativo & $\begin{array}{c}\text { Martins } \\
(2004)\end{array}$ & Atonal \\
\hline 180 & /nã̀/ & nã & Dizer & $\begin{array}{l}\text { Verbo Ativo } \\
\text { Transitivo e } \\
\text { ditransitivo } \\
\end{array}$ & $\begin{array}{c}\text { Martins } \\
(2004)\end{array}$ & Atonal \\
\hline 181 & $/ w^{?} \gamma^{\prime} \mathrm{j} /$ & w'âay & Falar & $\begin{array}{l}\text { Verbo Ativo } \\
\text { Transitivo e } \\
\text { ditransitivo }\end{array}$ & $\begin{array}{l}\text { Martins } \\
(2004)\end{array}$ & Ascendente \\
\hline 182 & / fúk/ & suuk & Caçar & $\begin{array}{l}\text { Verbo Ativo } \\
\text { Intransitivo }\end{array}$ & $\begin{array}{l}\text { Martins } \\
(2004) \\
\end{array}$ & Ascendente \\
\hline 183 & /ç̀ेb/ & çâab & Mudar & $\begin{array}{l}\text { Verbo Ativo } \\
\text { Intransitivo } \\
\end{array}$ & $\begin{array}{l}\text { Martins } \\
(2004) \\
\end{array}$ & Descendente \\
\hline 184 & /báw? & baaw' & $\begin{array}{l}\text { Gritar de } \\
\text { dor }\end{array}$ & $\begin{array}{l}\text { Verbo Ativo } \\
\text { Intransitivo }\end{array}$ & $\begin{array}{l}\text { Martins } \\
(2004)\end{array}$ & Ascendente \\
\hline 185 & /peg/ & peg & $\begin{array}{l}\text { Ser grande } \\
\text { (genérico) }\end{array}$ & $\begin{array}{c}\text { Verbo Estativo } \\
\text { descritivo } \\
\text { atributivo }\end{array}$ & $\begin{array}{l}\text { Martins } \\
(2004)\end{array}$ & Atonal \\
\hline 186 & /nét/ & neet & Ser raso & Verbo Estativo & $\begin{array}{c}\text { Martins } \\
(2004) \\
\end{array}$ & Descendente \\
\hline 187 & /ju?/ & $\mathrm{yu}^{\prime}$ & $\begin{array}{c}\text { Estar } \\
\text { quente }\end{array}$ & Verbo Estativo & $\begin{array}{c}\text { Martins } \\
(2004) \\
\end{array}$ & Atonal \\
\hline 188 & /kŕt/ & kâat & Estar de pé & Verbo Estativo & $\begin{array}{l}\text { Martins } \\
(2004)\end{array}$ & Ascendente \\
\hline 189 & /jèn/ & yêen & $\begin{array}{c}\text { Estar } \\
\text { escondido }\end{array}$ & Verbo Estativo & $\begin{array}{l}\text { Martins } \\
(2004)\end{array}$ & Descendente \\
\hline 190 & /do? pèg/ & do' pêeg & $\begin{array}{l}\text { Fazer } \\
\text { grande }\end{array}$ & $\begin{array}{c}\text { Verbo } \\
\text { transitivado }\end{array}$ & $\begin{array}{l}\text { Martins } \\
(2004) \\
\end{array}$ & Descendente \\
\hline 191 & /jet/ & yêt & Deitar & Verbo estativo & $\begin{array}{l}\text { Martins } \\
(2004)\end{array}$ & Atonal \\
\hline 192 & /cà/ & çaa & Ser amargo & Verbo estativo & $\begin{array}{l}\text { Martins } \\
(2004)\end{array}$ & Descendente \\
\hline 193 & /nè/ & nêe & Fazer & $\begin{array}{c}\text { Verbo } \\
\text { Transitivo }\end{array}$ & $\begin{array}{l}\text { Martins } \\
(2004)\end{array}$ & Descendente \\
\hline 194 & /ne/ & nê & Fazer & $\begin{array}{c}\text { Verbo } \\
\text { Transitivo }\end{array}$ & $\begin{array}{l}\text { Martins } \\
(2004)\end{array}$ & Descendente \\
\hline 195 & /neh/ & nêr & Fazer & $\begin{array}{c}\text { Verbo } \\
\text { Intransitivado }\end{array}$ & $\begin{array}{l}\text { Martins } \\
(2004)\end{array}$ & Atonal \\
\hline 196 & /wum/ & wtm & Ser forte & Verbo Estativo & $\begin{array}{l}\text { Martins } \\
(2004) \\
\end{array}$ & Atonal \\
\hline 197 & $/ \mathrm{pi} / /$ & pis & Ser pouco & Verbo Estativo & $\begin{array}{l}\text { Martins } \\
(2004) \\
\end{array}$ & Atonal \\
\hline 198 & /ja?/ & ya' & Assar & Verbo Ativo & $\begin{array}{l}\text { Martins } \\
(2004)\end{array}$ & Atonal \\
\hline 199 & /xóp/ & xoop & Secar & $\begin{array}{c}\text { Verbo } \\
\text { Transitivo }\end{array}$ & $\begin{array}{l}\text { Martins } \\
(2004)\end{array}$ & Ascendente \\
\hline
\end{tabular}




\begin{tabular}{|c|c|c|c|c|c|c|}
\hline 200 & /хэр/ & xop & Secar & $\begin{array}{c}\text { Verbo } \\
\text { intransitivado }\end{array}$ & $\begin{array}{l}\text { Martins } \\
(2004)\end{array}$ & Atonal \\
\hline 201 & /ka?/ & ka' & $\begin{array}{c}\text { Estar } \\
\text { suspenso }\end{array}$ & Verbo Estativo & $\begin{array}{l}\text { Martins } \\
(2004)\end{array}$ & Atonal \\
\hline 202 & /ká?/ & kaa' & $\begin{array}{l}\text { Amarrar } \\
\text { (anzol) }\end{array}$ & $\begin{array}{c}\text { Verbo } \\
\text { Transitivo }\end{array}$ & $\begin{array}{l}\text { Martins } \\
(2004)\end{array}$ & Ascendente \\
\hline 203 & $/ \mathrm{R} \varepsilon \mathrm{d} /$ & 'ed & $\begin{array}{c}\text { Não ter } \\
\text { equilíbrio }\end{array}$ & Verbo Estativo & $\begin{array}{l}\text { Martins } \\
(2004) \\
\end{array}$ & Atonal \\
\hline 204 & /१ॄ̀d/ & 'eed & Virar & $\begin{array}{c}\text { Verbo } \\
\text { Transitivo }\end{array}$ & $\begin{array}{l}\text { Martins } \\
\text { (2004) }\end{array}$ & Descendente \\
\hline 205 & /kil / & ki' & Rachar & Verbo Estativo & $\begin{array}{l}\text { Martins } \\
(2004)\end{array}$ & Atonal \\
\hline 206 & /kí?/ & kii' & Abrir couro & $\begin{array}{c}\text { Verbo } \\
\text { Transitivo }\end{array}$ & $\begin{array}{l}\text { Martins } \\
(2004)\end{array}$ & Ascendente \\
\hline 207 & /wrg/ & wtg & Balançar & Verbo Estativo & $\begin{array}{l}\text { Martins } \\
(2004)\end{array}$ & Atonal \\
\hline 208 & /wr̀̀g/ & wutg & Sacudir & $\begin{array}{c}\text { Verbo Ativo } \\
\text { transitivo }\end{array}$ & $\begin{array}{l}\text { Martins } \\
(2004)\end{array}$ & Descendente \\
\hline 209 & $/ \mathrm{xrc} /$ & xâç & $\begin{array}{l}\text { Estar com a } \\
\text { cabeça } \\
\text { pelada }\end{array}$ & Verbo Estativo & $\begin{array}{l}\text { Martins } \\
(2004)\end{array}$ & Atonal \\
\hline 210 & /x'́c/ & xâaç & $\begin{array}{l}\text { Tirar a pele } \\
\text { da fruta }\end{array}$ & $\begin{array}{c}\text { Verbo Ativo } \\
\text { transitivo }\end{array}$ & $\begin{array}{l}\text { Martins } \\
(2004)\end{array}$ & Descendente \\
\hline 211 & /hว̃n/ & rõn & $\begin{array}{c}\text { Conferir, } \\
\text { contar }\end{array}$ & Verbo Estativo & $\begin{array}{l}\text { Martins } \\
(2004)\end{array}$ & Atonal \\
\hline 212 & /hכ̃̀n/ & rõn & $\begin{array}{l}\text { Subir em } \\
\text { árvore para } \\
\text { conferir } \\
\text { localização } \\
\end{array}$ & Verbo Ativo & $\begin{array}{l}\text { Martins } \\
(2004)\end{array}$ & Atonal \\
\hline 213 & /xû́n? & Xũunh' & Conferir & $\begin{array}{c}\text { Não } \\
\text { classificado por } \\
\text { Martins }\end{array}$ & $\begin{array}{l}\text { Martins } \\
(2004)\end{array}$ & Descendente \\
\hline 214 & /han/ & ran & Aparecer & Verbo estativo & $\begin{array}{l}\text { Martins } \\
(2004)\end{array}$ & Atonal \\
\hline 215 & /hàn/ & raan & Avisar & Verbo Ativo & $\begin{array}{l}\text { Martins } \\
(2004)\end{array}$ & Descendente \\
\hline 216 & $/ \mathrm{xrd} /$ & xâd & Passar & $\begin{array}{c}\text { Verbo estativo } \\
\text { / movimento }\end{array}$ & $\begin{array}{l}\text { Martins } \\
(2004)\end{array}$ & Atonal \\
\hline 217 & /tak/ & tak & $\begin{array}{c}\text { Passar } \\
\text { sorva }\end{array}$ & & $\begin{array}{l}\text { Martins } \\
(2004)\end{array}$ & Atonal \\
\hline 218 & /x̧̀d/ & xâad & $\begin{array}{l}\text { Passar } \\
\text { olhando } \\
\text { com } \\
\text { atenção; } \\
\text { procurar }\end{array}$ & Verbo Ativo & $\begin{array}{l}\text { Martins } \\
(2004)\end{array}$ & Descendente \\
\hline 219 & /drh/ & dâr & $\begin{array}{c}\text { Movimenta } \\
\mathrm{r} \\
\text { subitament } \\
\mathrm{e} \\
\end{array}$ & $\begin{array}{l}\text { Verbo de } \\
\text { movimento }\end{array}$ & $\begin{array}{l}\text { Martins } \\
(2004)\end{array}$ & Atonal \\
\hline 220 & /j5̆h/ & yõor & $\begin{array}{l}\text { Passar } \\
\text { remédio }\end{array}$ & $\begin{array}{l}\text { Verbo Ativo } \\
\text { bitransitivo }\end{array}$ & $\begin{array}{l}\text { Martins } \\
(2004)\end{array}$ & Descendente \\
\hline 221 & $/ \int \mathrm{i} /$ & sii & $\begin{array}{l}\text { Furar com } \\
\text { a unha }\end{array}$ & Verbo Ativo & $\begin{array}{l}\text { Martins } \\
(2004)\end{array}$ & Descendente \\
\hline
\end{tabular}




\begin{tabular}{|c|c|c|c|c|c|c|}
\hline 222 & $/ / \mathrm{ib} /$ & siib & Beliscar & Verbo Ativo & $\begin{array}{l}\text { Martins } \\
(2004)\end{array}$ & Descendente \\
\hline 223 & /wº̀b/ & w'ôob & $\begin{array}{c}\text { Por alguma } \\
\text { coisa em } \\
\text { cima da } \\
\text { outra }\end{array}$ & Verbo Ativo & $\begin{array}{l}\text { Martins } \\
\text { (2004) }\end{array}$ & Descendente \\
\hline 224 & /wòb/ & wôob & $\begin{array}{l}\text { Estar em } \\
\text { cima }\end{array}$ & Verbo Estativo & $\begin{array}{c}\text { Martins } \\
(2004)\end{array}$ & Descendente \\
\hline 225 & /woj/ & woy & $\begin{array}{l}\text { Sovinar, } \\
\text { guardar }\end{array}$ & Verbo estativo & $\begin{array}{l}\text { Martins } \\
(2004)\end{array}$ & Atonal \\
\hline 226 & /wòj/ & wooy & $\begin{array}{c}\text { Guardar } \\
\text { para o } \\
\text { outro não } \\
\text { ficar sem }\end{array}$ & Verbo Ativo & $\begin{array}{l}\text { Martins } \\
\text { (2004) }\end{array}$ & Descendente \\
\hline 227 & /dak/ & dak & Vestir-se & Verbo estativo & $\begin{array}{l}\text { Martins } \\
(2004)\end{array}$ & Atonal \\
\hline 228 & /dák/ & daak & $\begin{array}{c}\text { Pôr alguma } \\
\text { coisa }\end{array}$ & Verbo Ativo & $\begin{array}{l}\text { Martins } \\
(2004) \\
\end{array}$ & Descendente \\
\hline 229 & $/ \int \mathrm{J} \mathrm{x} /$ & sox & $\begin{array}{c}\text { Furar a } \\
\text { terra para } \\
\text { plantar } \\
\text { maniva } \\
\end{array}$ & Verbo Estativo & $\begin{array}{c}\text { Martins } \\
(2004)\end{array}$ & Atonal \\
\hline 230 & /אכ́x/ & soox & $\begin{array}{c}\text { Furar, dar } \\
\text { injeção, dar } \\
\text { pontada, } \\
\text { riscar } \\
\text { fósforo } \\
\end{array}$ & Verbo Ativo & $\begin{array}{l}\text { Martins } \\
\text { (2004) }\end{array}$ & Descendente \\
\hline 231 & /lók/ & look & $\begin{array}{c}\text { Furar } \\
\text { (fazer } \\
\text { buraco na } \\
\text { panela, } \\
\text { forno, rede, } \\
\text { casa) } \\
\end{array}$ & Verbo Ativo & $\begin{array}{l}\text { Martins } \\
\text { (2004) }\end{array}$ & Ascendente \\
\hline 232 & /hob/ & rob & Furar & $\begin{array}{l}\text { Verbo Ativo } \\
\text { Intransitivo }\end{array}$ & $\begin{array}{c}\text { Martins } \\
(2004)\end{array}$ & Atonal \\
\hline 233 & /xob/ & xob & Furar & $\begin{array}{l}\text { Verbo Ativo } \\
\text { Intransitivo }\end{array}$ & $\begin{array}{l}\text { Martins } \\
(2004)\end{array}$ & Atonal \\
\hline 234 & /xćp/ & xeep & Varrer & Verbo ativo & $\begin{array}{l}\text { Martins } \\
(2004)\end{array}$ & Ascendente \\
\hline 235 & /hẽd-jú?/ & rẽed-yuu' & $\begin{array}{c}\text { Tornar-se } \\
\text { quente }\end{array}$ & $\begin{array}{c}\text { Verbo } \\
\text { transitivizado }\end{array}$ & $\begin{array}{l}\text { Martins } \\
(2004) \\
\end{array}$ & Ascendente \\
\hline 236 & /bów/ & bôow & $\begin{array}{l}\text { Abrir peixe } \\
\text { para assar }\end{array}$ & Verbo ativo & $\begin{array}{c}\text { Martins } \\
(2004) \\
\end{array}$ & Descendente \\
\hline 237 & /j $\tilde{\varepsilon} \mathrm{m} /$ & yẽem & $\begin{array}{l}\text { Estar } \\
\text { pronto }\end{array}$ & Verbo estativo & $\begin{array}{c}\text { Martins } \\
(2004) \\
\end{array}$ & Atonal \\
\hline 238 & /wak/ & wak & Estar duro & Verbo estativo & $\begin{array}{l}\text { Martins } \\
(2004)\end{array}$ & Atonal \\
\hline 239 & /tek/ & têk & $\begin{array}{c}\text { Bater } \\
\text { pressionan } \\
\text { do contra } \\
\text { algo (ex. } \\
\text { bater roupa } \\
\text { na pedra) }\end{array}$ & $\begin{array}{l}\text { Verbo Ativo } \\
\text { Transitivo }\end{array}$ & $\begin{array}{l}\text { Martins } \\
\text { (2004) }\end{array}$ & Atonal \\
\hline
\end{tabular}




\begin{tabular}{|c|c|c|c|c|c|c|}
\hline 240 & $/ \mathrm{tok} /$ & tok & $\begin{array}{c}\text { Bater na } \\
\text { cabeça, } \\
\text { dando } \\
\text { cascudos }\end{array}$ & $\begin{array}{c}\text { Verbo Ativo } \\
\text { Transitivo }\end{array}$ & $\begin{array}{l}\text { Martins } \\
(2004)\end{array}$ & Atonal \\
\hline 241 & / đép/ & sêep & $\begin{array}{l}\text { Bater } \\
\text { puxando a } \\
\text { orelha de } \\
\text { alguém }\end{array}$ & $\begin{array}{c}\text { Verbo Ativo } \\
\text { Transitivo }\end{array}$ & $\begin{array}{l}\text { Martins } \\
(2004)\end{array}$ & Ascendente \\
\hline 242 & /tũun? / & tũn' & $\begin{array}{l}\text { Bater com } \\
\text { a cabeça, } \\
\text { cabecear }\end{array}$ & $\begin{array}{c}\text { Verbo Ativo } \\
\text { Transitivo }\end{array}$ & $\begin{array}{l}\text { Martins } \\
(2004)\end{array}$ & Atonal \\
\hline 243 & /tấw/ & tãaw & $\begin{array}{l}\text { Bater com } \\
\text { alguma } \\
\text { coisa para } \\
\text { tirar o } \\
\text { líquido (ex. } \\
\text { bater cana, } \\
\text { timbó) }\end{array}$ & $\begin{array}{c}\text { Verbo Ativo } \\
\text { Transitivo }\end{array}$ & $\begin{array}{l}\text { Martins } \\
(2004)\end{array}$ & Ascendente \\
\hline 244 & /Rũ̀m/ & 'ũum & $\begin{array}{c}\text { Bater } \\
\text { (genérico) }\end{array}$ & $\begin{array}{c}\text { Verbo Ativo } \\
\text { Transitivo }\end{array}$ & $\begin{array}{l}\text { Martins } \\
(2004)\end{array}$ & Descendente \\
\hline 245 & /jũw? / & yũw' & $\begin{array}{l}\text { Bater } \\
\text { dando soco } \\
\text { quando } \\
\text { está } \\
\text { brigando }\end{array}$ & $\begin{array}{c}\text { Verbo Ativo } \\
\text { Transitivo }\end{array}$ & $\begin{array}{l}\text { Martins } \\
(2004)\end{array}$ & Atonal \\
\hline 246 & /m?ćp/ & m'eep & $\begin{array}{c}\text { Bater } \\
\text { dando } \\
\text { pescoção }\end{array}$ & $\begin{array}{c}\text { Verbo Ativo } \\
\text { Transitivo }\end{array}$ & $\begin{array}{l}\text { Martins } \\
(2004)\end{array}$ & Descendente \\
\hline 247 & /nэg/ & nog & $\begin{array}{c}\text { Bater } \\
\text { dando soco } \\
\text { em alguém }\end{array}$ & $\begin{array}{c}\text { Verbo Ativo } \\
\text { Transitivo }\end{array}$ & $\begin{array}{l}\text { Martins } \\
(2004)\end{array}$ & Atonal \\
\hline 248 & /nux/ & ntx & $\begin{array}{c}\text { Bater a } \\
\text { cabeça no } \\
\text { pau }\end{array}$ & $\begin{array}{l}\text { Verbo Ativo } \\
\text { Intransitivo }\end{array}$ & $\begin{array}{l}\text { Martins } \\
(2004)\end{array}$ & Atonal \\
\hline 249 & $/ \int \widetilde{x} \mathrm{n} /$ & sõon & $\begin{array}{l}\text { Bater o pé } \\
\text { no toco }\end{array}$ & $\begin{array}{l}\text { Verbo Ativo } \\
\text { Intransitivo }\end{array}$ & $\begin{array}{l}\text { Martins } \\
(2004)\end{array}$ & Atonal \\
\hline 250 & $/ \mathrm{l} \gamma \mathrm{j} /$ & lây & $\begin{array}{c}\text { Bater o } \\
\text { sino }\end{array}$ & $\begin{array}{l}\text { Verbo Ativo } \\
\text { Intransitivo } \\
\end{array}$ & $\begin{array}{l}\text { Martins } \\
(2004)\end{array}$ & Atonal \\
\hline 251 & /jok/ & yok & Nadar & $\begin{array}{l}\text { Verbo Ativo } \\
\text { intransitivo }\end{array}$ & $\begin{array}{l}\text { Martins } \\
(2004)\end{array}$ & Atonal \\
\hline 252 & /hod/ & rod & Sair & $\begin{array}{l}\text { Verbo Ativo } \\
\text { intransitivo }\end{array}$ & $\begin{array}{l}\text { Martins } \\
(2004)\end{array}$ & Atonal \\
\hline 253 & /Rว̆t/ & 'õot & Chorar & $\begin{array}{l}\text { Verbo Ativo } \\
\text { intransitivo }\end{array}$ & $\begin{array}{l}\text { Martins } \\
\text { (2004) }\end{array}$ & Descendente \\
\hline 254 & /Rã/ & ‘̃̃ & Dormir & $\begin{array}{l}\text { Verbo Ativo } \\
\text { intransitivo }\end{array}$ & $\begin{array}{l}\text { Martins } \\
(2004)\end{array}$ & Atonal \\
\hline 255 & /xúup/ & xнup & Sonhar & $\begin{array}{l}\text { Verbo Ativo } \\
\text { intransitivo }\end{array}$ & $\begin{array}{l}\text { Martins } \\
(2004)\end{array}$ & Ascendente \\
\hline 256 & /xub/ & xub & $\begin{array}{l}\text { Estar com } \\
\text { fome }\end{array}$ & $\begin{array}{c}\text { Verbo Ativo } \\
\text { Transitivo }\end{array}$ & $\begin{array}{l}\text { Martins } \\
(2004)\end{array}$ & Atonal \\
\hline 257 & //ip/ & sip & $\begin{array}{l}\text { Querer } \\
\text { rápido }\end{array}$ & $\begin{array}{c}\text { Verbo Ativo } \\
\text { Transitivo } \\
\end{array}$ & $\begin{array}{l}\text { Martins } \\
(2004)\end{array}$ & Atonal \\
\hline 258 & $/ \mathrm{h}$ j̀j/ & rõoy & Focar & Verbo Ativo & Martins & Descendente \\
\hline
\end{tabular}




\begin{tabular}{|c|c|c|c|c|c|c|}
\hline & & & & Transitivo & $(2004)$ & \\
\hline 259 & /dák/ & daak & Colocar & $\begin{array}{c}\text { Verbo Ativo } \\
\text { Transitivo }\end{array}$ & $\begin{array}{l}\text { Martins } \\
\text { (2004) }\end{array}$ & Atonal \\
\hline 260 & /jug/ & yug & Fazer vinho & $\begin{array}{l}\text { Verbo Ativo } \\
\text { bitransitivo }\end{array}$ & $\begin{array}{l}\text { Martins } \\
(2004)\end{array}$ & Atonal \\
\hline 261 & /buj/ & buy & Jogar & $\begin{array}{l}\text { Verbo Ativo } \\
\text { bitransitivo }\end{array}$ & $\begin{array}{l}\text { Martins } \\
\text { (2004) }\end{array}$ & Atonal \\
\hline 262 & /xaw/ & xaw & Ferver & $\begin{array}{l}\text { Verbo de } \\
\text { processo }\end{array}$ & $\begin{array}{l}\text { Martins } \\
(2004)\end{array}$ & Atonal \\
\hline 263 & /nrx-dot/ & nâx-doj & Chover & $\begin{array}{l}\text { Verbo de } \\
\text { processo }\end{array}$ & $\begin{array}{l}\text { Martins } \\
(2004)\end{array}$ & Atonal \\
\hline 264 & /dok/ & dok & Apagar & $\begin{array}{l}\text { Verbo de } \\
\text { processo }\end{array}$ & $\begin{array}{l}\text { Martins } \\
(2004) \\
\end{array}$ & Atonal \\
\hline 265 & /nrx-dof-ce/ & nâz-doj-çê & Chuviscar & $\begin{array}{l}\text { Verbo de } \\
\text { processo }\end{array}$ & $\begin{array}{l}\text { Martins } \\
\text { (2004) }\end{array}$ & Atonal \\
\hline 266 & /wrt-úb/ & wât-utb & Amanhecer & $\begin{array}{l}\text { Verbo de } \\
\text { processo }\end{array}$ & $\begin{array}{l}\text { Martins } \\
(2004)\end{array}$ & Descendente \\
\hline 267 & /du?-xu/ & $d u^{\prime}-x u$ & Entardecer & $\begin{array}{l}\text { Verbo de } \\
\text { processo }\end{array}$ & $\begin{array}{l}\text { Martins } \\
(2004)\end{array}$ & Atonal \\
\hline 268 & /cem-xul/ & çêm-xu & Anoitecer & $\begin{array}{l}\text { Verbo de } \\
\text { processo }\end{array}$ & $\begin{array}{l}\text { Martins } \\
\text { (2004) }\end{array}$ & Atonal \\
\hline 269 & 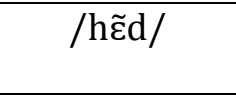 & rẽd & $\begin{array}{l}\text { Possuir, } \\
\text { adquirir }\end{array}$ & $\begin{array}{c}\text { Verbo } \\
\text { Transitivo }\end{array}$ & $\begin{array}{l}\text { Martins } \\
(2004)\end{array}$ & Atonal \\
\hline 270 & /wŕt-wa/ & wâat-wa & $\begin{array}{l}\text { Entardecer } \\
\text { / dia-estar } \\
\text { maduro } \\
\text { (céu } \\
\text { avermelha } \\
\text { do, pôr do } \\
\text { sol) } \\
\end{array}$ & $\begin{array}{l}\text { Verbo de } \\
\text { processo }\end{array}$ & $\begin{array}{l}\text { Martins } \\
\text { (2004) }\end{array}$ & Descendente \\
\hline 271 & /cef jét/ & çêj yêet & $\begin{array}{c}\text { Entardecer } \\
\text { / brilhar do } \\
\text { céu está } \\
\text { deitando } \\
\end{array}$ & $\begin{array}{l}\text { Verbo de } \\
\text { processo }\end{array}$ & $\begin{array}{c}\text { Martins } \\
(2004)\end{array}$ & Descendente \\
\hline 272 & /cem-xu/ & çêm-xt & $\begin{array}{c}\text { Anoitecer/ } \\
\text { cair da } \\
\text { noite }\end{array}$ & $\begin{array}{l}\text { Verbo de } \\
\text { processo }\end{array}$ & $\begin{array}{l}\text { Martins } \\
(2004)\end{array}$ & Atonal \\
\hline 273 & 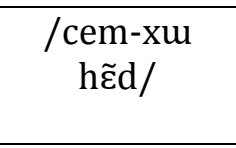 & çêm-xu rẽd & $\begin{array}{l}\text { Anoitecer } \\
\text { /começar a } \\
\text { anoitecer }\end{array}$ & $\begin{array}{l}\text { Verbo de } \\
\text { processo }\end{array}$ & $\begin{array}{c}\text { Martins } \\
(2004)\end{array}$ & Atonal \\
\hline 274 & /cem-ãm/ & çêm-ãm & $\begin{array}{c}\text { Anoitecer/ } \\
\text { bem de } \\
\text { noitinha } \\
\end{array}$ & $\begin{array}{l}\text { Verbo de } \\
\text { processo }\end{array}$ & $\begin{array}{l}\text { Martins } \\
\text { (2004) }\end{array}$ & Atonal \\
\hline 275 & $\begin{array}{l}\text { /cem-?uj- } \\
\text { ãm/ }\end{array}$ & cêm-'uy-ãm & $\begin{array}{c}\text { Fazer-se } \\
\text { noite }\end{array}$ & $\begin{array}{l}\text { Verbo de } \\
\text { processo }\end{array}$ & $\begin{array}{l}\text { Martins } \\
(2004) \\
\end{array}$ & Atonal \\
\hline 276 & /kub-xu/ & kub-xu & $\begin{array}{c}\text { Anoitecer/ } \\
\text { escurecer, } \\
\text { descer da } \\
\text { noite' }\end{array}$ & $\begin{array}{l}\text { Verbo de } \\
\text { processo }\end{array}$ & $\begin{array}{l}\text { Martins } \\
(2004)\end{array}$ & Atonal \\
\hline 277 & /wr-?ùub/ & wâ-'uub & $\begin{array}{c}\text { Amanhecer } \\
\text { / acordar o } \\
\text { dia }\end{array}$ & $\begin{array}{l}\text { Verbo de } \\
\text { processo }\end{array}$ & $\begin{array}{l}\text { Martins } \\
\text { (2004) }\end{array}$ & Descendente \\
\hline 278 & /wrt-xu/ & wât-xt & Amanhecer & Verbo de & Martins & Atonal \\
\hline
\end{tabular}




\begin{tabular}{|c|c|c|c|c|c|c|}
\hline & & & /cair o dia & processo & $(2004)$ & \\
\hline 279 & /wrt-púd/ & wât-xt & $\begin{array}{l}\text { Estar para } \\
\text { amanhecer }\end{array}$ & $\begin{array}{l}\text { Verbo de } \\
\text { processo }\end{array}$ & $\begin{array}{c}\text { Martins } \\
(2004)\end{array}$ & Atonal \\
\hline 280 & /wrt-xa/ & wât-xa & $\begin{array}{l}\text { Agachar o } \\
\text { dia }\end{array}$ & $\begin{array}{l}\text { Verbo de } \\
\text { processo }\end{array}$ & $\begin{array}{c}\text { Martins } \\
\text { (2004) }\end{array}$ & Atonal \\
\hline 281 & $\begin{array}{l}\text { /wrt-hũ? } \\
\text { Pujãm/ }\end{array}$ & wât-rũ'-'uyãm & $\begin{array}{l}\text { Quando o } \\
\text { dia acabar }\end{array}$ & $\begin{array}{l}\text { Verbo de } \\
\text { processo }\end{array}$ & $\begin{array}{l}\text { Martins } \\
(2004)\end{array}$ & Atonal \\
\hline 282 & /be? hãm/ & be' rãm & Clarear & $\begin{array}{l}\text { Verbo de } \\
\text { processo }\end{array}$ & $\begin{array}{l}\text { Martins } \\
(2004)\end{array}$ & Atonal \\
\hline 283 & /nĩ/ & nĩ & $\begin{array}{l}\text { Estar, } \\
\text { existir, } \\
\text { haver }\end{array}$ & $\begin{array}{c}\text { Verbo estativo } \\
\text { equativo } \\
\text { existencial }\end{array}$ & $\begin{array}{l}\text { Martins } \\
\text { (2004) }\end{array}$ & Atonal \\
\hline 284 & $/ \mathrm{m} \tilde{\mathrm{g}} \mathrm{h} /$ & mẽr & $\begin{array}{l}\text { Não estar, } \\
\text { não existir, } \\
\text { não haver }\end{array}$ & $\begin{array}{l}\text { Verbo estativo } \\
\text { equativo } \\
\text { existencial }\end{array}$ & $\begin{array}{l}\text { Martins } \\
\text { (2004) }\end{array}$ & Atonal \\
\hline 285 & /hew/ & rew & $\begin{array}{l}\text { Ter ou } \\
\text { haver } \\
\text { muitos }\end{array}$ & $\begin{array}{c}\text { Verbo estativo } \\
\text { equativo } \\
\text { existencial } \\
\end{array}$ & $\begin{array}{l}\text { Martins } \\
\text { (2004) }\end{array}$ & Atonal \\
\hline 286 & /héw/ & reew & Ser muito & $\begin{array}{l}\text { Verbo estativo } \\
\text { equativo } \\
\text { identificacional }\end{array}$ & $\begin{array}{l}\text { Martins } \\
(2004)\end{array}$ & Descendente \\
\hline 287 & /mấj/ & mãay & $\begin{array}{c}\text { Ser } \\
\text { intensificad } \\
o \\
\text { (referente } \\
\text { à } \\
\text { quantidade } \\
\text { e } \\
\text { qualidade) }\end{array}$ & $\begin{array}{l}\text { Verbo estativo } \\
\text { equativo } \\
\text { identificacional }\end{array}$ & $\begin{array}{l}\text { Martins } \\
(2004)\end{array}$ & Descendente \\
\hline 288 & /púd/ & putd & $\begin{array}{c}\text { Ser } \\
\text { intensificad } \\
o \\
\text { (referente } \\
\text { à } \\
\text { quantidade } \\
\text { e } \\
\text { qualidade) }\end{array}$ & $\begin{array}{l}\text { Verbo estativo } \\
\text { equativo } \\
\text { identificacional }\end{array}$ & $\begin{array}{l}\text { Martins } \\
(2004)\end{array}$ & Descendente \\
\hline 289 & /mãj/ & mãy & Não ser & $\begin{array}{c}\text { Verbo estativo } \\
\text { equativo } \\
\text { identificacional }\end{array}$ & $\begin{array}{l}\text { Martins } \\
\text { (2004) }\end{array}$ & Atonal \\
\hline 290 & /Ramaj/ & 'amay & $\begin{array}{c}\text { Ser um } \\
\text { pouco }\end{array}$ & $\begin{array}{l}\text { Verbo estativo } \\
\text { equativo } \\
\text { identificacional }\end{array}$ & $\begin{array}{l}\text { Martins } \\
\text { (2004) }\end{array}$ & Atonal \\
\hline 291 & /wùd/ & wutd & $\begin{array}{c}\text { Ser } \\
\text { (passado) } \\
\text { ou } \\
\text { possibilida } \\
\text { de de ser }\end{array}$ & $\begin{array}{l}\text { Verbo estativo } \\
\text { equativo } \\
\text { identificacional }\end{array}$ & $\begin{array}{l}\text { Martins } \\
(2004)\end{array}$ & Descendente \\
\hline 292 & $/ \mathrm{m} \tilde{\varepsilon} \mathrm{h} \tilde{\varepsilon} \mathrm{d} /$ & mẽrẽd & $\begin{array}{l}\text { Estar, } \\
\text { existir um } \\
\text { pouco }\end{array}$ & $\begin{array}{l}\text { Verbo estativo } \\
\text { equativo }\end{array}$ & $\begin{array}{l}\text { Martins } \\
\text { (2004) }\end{array}$ & Atonal \\
\hline 293 & /púud Ramãj/ & putd 'amãy & Ser quase & $\begin{array}{c}\text { Verbo estativo } \\
\text { equativo }\end{array}$ & $\begin{array}{l}\text { Martins } \\
(2004)\end{array}$ & Descendente \\
\hline
\end{tabular}




\begin{tabular}{|c|c|c|c|c|c|c|}
\hline 294 & /xup-mẽh/ & xup-mẽr & $\begin{array}{l}\text { Não existir } \\
\text { gente }\end{array}$ & $\begin{array}{c}\text { Verbo estativo } \\
\text { equativo com } \\
\text { incorporação } \\
\text { de nominais }\end{array}$ & $\begin{array}{l}\text { Martins } \\
(2004)\end{array}$ & Atonal \\
\hline 295 & /Rãmãj/ & ‘ãmãy & $\begin{array}{l}\text { Meio } \\
\text { rápido }\end{array}$ & $\begin{array}{l}\text { Verbo estativo } \\
\text { equativo com } \\
\text { incorporação } \\
\text { de advérbios }\end{array}$ & $\begin{array}{l}\text { Martins } \\
(2004)\end{array}$ & Atonal \\
\hline 296 & /ta?-mãj/ & ta'-mãy & $\begin{array}{l}\text { Não ser } \\
\text { distante }\end{array}$ & $\begin{array}{c}\text { Verbo estativo } \\
\text { equativo com } \\
\text { incorporação } \\
\text { de } \\
\text { pronominais }\end{array}$ & $\begin{array}{l}\text { Martins } \\
(2004)\end{array}$ & Atonal \\
\hline 297 & /hõt-amãj/ & rõt-amãy & Meio longe & $\begin{array}{c}\text { Verbo estativo } \\
\text { equativo com } \\
\text { incorporação } \\
\text { de } \\
\text { pronominais }\end{array}$ & $\begin{array}{l}\text { Martins } \\
(2004)\end{array}$ & Atonal \\
\hline 298 & /nũ?-mãj/ & nũ'-mãy & Outro & $\begin{array}{c}\text { Verbo estativo } \\
\text { equativo com } \\
\text { incorporação } \\
\text { de } \\
\text { pronominais }\end{array}$ & $\begin{array}{l}\text { Martins } \\
(2004)\end{array}$ & Atonal \\
\hline 299 & /j’òj/ & y'ôoy & $\begin{array}{c}\text { Ser } \\
\text { comprido e } \\
\text { mais alto } \\
\text { de todos } \\
\text { (ex. árvore } \\
\text { mais alta } \\
\text { que as } \\
\text { outras) }\end{array}$ & $\begin{array}{c}\text { Verbo estativo } \\
\text { descritivo } \\
\text { atributivo }\end{array}$ & $\begin{array}{l}\text { Martins } \\
(2004)\end{array}$ & Descendente \\
\hline 300 & /jग/ & yos & $\begin{array}{c}\text { Ter um } \\
\text { lado mais } \\
\text { baixo que o } \\
\text { outro } \\
\text { (ex. lábios } \\
\text { grossos e } \\
\text { grandes; } \\
\text { rede com } \\
\text { um dos } \\
\text { lados mais } \\
\text { baixo) }\end{array}$ & $\begin{array}{c}\text { Verbo estativo } \\
\text { descritivo } \\
\text { atributivo }\end{array}$ & $\begin{array}{l}\text { Martins } \\
(2004)\end{array}$ & Atonal \\
\hline 301 & /lĩ / & lĩ & $\begin{array}{l}\text { Ser pintado } \\
\text { estampado } \\
\text { (ex. rede } \\
\text { estampada) }\end{array}$ & $\begin{array}{l}\text { Verbo estativo } \\
\text { descritivo } \\
\text { atributivo }\end{array}$ & $\begin{array}{l}\text { Martins } \\
(2004)\end{array}$ & Atonal \\
\hline 302 & /xว̀d/ & xood & $\begin{array}{c}\text { Ser } \\
\text { pintado, } \\
\text { malhado } \\
\text { (ex. } \\
\text { cachorro) } \\
\end{array}$ & $\begin{array}{c}\text { Verbo estativo } \\
\text { descritivo } \\
\text { atributivo }\end{array}$ & $\begin{array}{l}\text { Martins } \\
(2004)\end{array}$ & Descendente \\
\hline 303 & /lı̃ / & lõ & $\begin{array}{l}\text { Ser pintado } \\
\text { de bolinha, }\end{array}$ & $\begin{array}{c}\text { Verbo estativo } \\
\text { descritivo }\end{array}$ & $\begin{array}{l}\text { Martins } \\
(2004)\end{array}$ & Atonal \\
\hline
\end{tabular}




\begin{tabular}{|c|c|c|c|c|c|c|}
\hline & & & salpicado & atributivo & & \\
\hline 304 & /ca/ & ça & $\begin{array}{l}\text { Ser preto; } \\
\text { ser amargo }\end{array}$ & $\begin{array}{c}\text { Verbo estativo } \\
\text { descritivo } \\
\text { atributivo }\end{array}$ & $\begin{array}{c}\text { Martins } \\
(2004)\end{array}$ & Atonal \\
\hline 305 & /wáh/ & waar & $\begin{array}{l}\text { Ser verde } \\
\text { porque não } \\
\text { está } \\
\text { maduro } \\
\text { (ex. banana } \\
\text { verde) }\end{array}$ & $\begin{array}{c}\text { Verbo estativo } \\
\text { descritivo } \\
\text { atributivo }\end{array}$ & $\begin{array}{c}\text { Martins } \\
(2004)\end{array}$ & Descendente \\
\hline 306 & $/$ / ej/ & sêy & $\begin{array}{l}\text { Ser peludo } \\
\text { (ex. rabo de } \\
\text { veado, } \\
\text { cavalo, etc) }\end{array}$ & $\begin{array}{c}\text { Verbo estativo } \\
\text { descritivo } \\
\text { atributivo }\end{array}$ & $\begin{array}{c}\text { Martins } \\
(2004)\end{array}$ & Atonal \\
\hline 307 & /lãk/ & lõk & $\begin{array}{l}\text { Ser esférico } \\
\text { e pequeno } \\
\text { (ex. buraco, } \\
\text { fezes, etc) }\end{array}$ & $\begin{array}{c}\text { Verbo estativo } \\
\text { descritivo } \\
\text { atributivo }\end{array}$ & $\begin{array}{c}\text { Martins } \\
\text { (2004) }\end{array}$ & Atonal \\
\hline 308 & /kũk/ & kũk & $\begin{array}{c}\text { Ser } \\
\text { torneado }\end{array}$ & $\begin{array}{c}\text { Verbo estativo } \\
\text { descritivo } \\
\text { atributivo }\end{array}$ & $\begin{array}{c}\text { Martins } \\
(2004)\end{array}$ & Atonal \\
\hline 309 & $\begin{array}{c}\text { /drw } \\
\text { xubJכ̃k/ }\end{array}$ & dâw xubsõk & Estar triste & $\begin{array}{c}\text { Verbos } \\
\text { estativos } \\
\text { descritivos } \\
\text { qualificativos }\end{array}$ & $\begin{array}{c}\text { Martins } \\
(2004)\end{array}$ & Atonal \\
\hline 310 & /drw tr̀w/ & dâw tâaw & Estar bravo & $\begin{array}{c}\text { Verbos } \\
\text { estativos } \\
\text { descritivos } \\
\text { qualificativos }\end{array}$ & $\begin{array}{l}\text { Martins } \\
(2004)\end{array}$ & Atonal \\
\hline 311 & /drw Rằm/ & dâw 'ãam & $\begin{array}{l}\text { Estar com } \\
\text { medo }\end{array}$ & $\begin{array}{c}\text { Verbos } \\
\text { estativos } \\
\text { descritivos } \\
\text { qualificativos }\end{array}$ & $\begin{array}{c}\text { Martins } \\
(2004)\end{array}$ & Descendente \\
\hline 312 & /drw kŕh/ & dâw kâar & $\begin{array}{c}\text { Estar } \\
\text { sofrendo, } \\
\text { ser pobre }\end{array}$ & $\begin{array}{c}\text { Verbos } \\
\text { estativos } \\
\text { descritivos } \\
\text { qualificativos }\end{array}$ & $\begin{array}{c}\text { Martins } \\
(2004)\end{array}$ & Descendente \\
\hline 313 & /drw wej/ & dâw wey & $\begin{array}{l}\text { Estar mole, } \\
\text { estar com } \\
\text { preguiça }\end{array}$ & $\begin{array}{c}\text { Verbos } \\
\text { estativos } \\
\text { descritivos } \\
\text { qualificativos }\end{array}$ & $\begin{array}{c}\text { Martins } \\
\text { (2004) }\end{array}$ & Atonal \\
\hline 314 & /lrk/ & lâk & $\begin{array}{c}\text { Ser magro } \\
\text { por } \\
\text { natureza } \\
\text { (torna o } \\
\text { osso } \\
\text { visível) }\end{array}$ & $\begin{array}{c}\text { Verbos } \\
\text { estativos } \\
\text { descritivos } \\
\text { qualificativos }\end{array}$ & $\begin{array}{c}\text { Martins } \\
(2004)\end{array}$ & Atonal \\
\hline 315 & /lãk/ & lãk & $\begin{array}{c}\text { Ser } \\
\text { despelado, } \\
\text { estar } \\
\text { descampad }\end{array}$ & $\begin{array}{c}\text { Verbos } \\
\text { estativos } \\
\text { descritivos } \\
\text { qualificativos }\end{array}$ & $\begin{array}{c}\text { Martins } \\
(2004)\end{array}$ & Atonal \\
\hline
\end{tabular}




\begin{tabular}{|c|c|c|c|c|c|c|}
\hline & & & $\begin{array}{c}\text { o (ex. } \\
\text { cabeça } \\
\text { pelada; } \\
\text { terreno } \\
\text { descampad } \\
\text { o) } \\
\end{array}$ & & & \\
\hline 316 & /le?/ & lê' & $\begin{array}{l}\text { Ser magro } \\
\text { e ter a } \\
\text { cabeça } \\
\text { grande }\end{array}$ & $\begin{array}{c}\text { Verbos } \\
\text { estativos } \\
\text { descritivos } \\
\text { qualificativos }\end{array}$ & $\begin{array}{c}\text { Martins } \\
\text { (2004) }\end{array}$ & Atonal \\
\hline 317 & $/ \mathrm{n}^{?} \mathrm{u}$ ńn & n'ũun & $\begin{array}{l}\text { Ser mole ou } \\
\text { bem cozido }\end{array}$ & $\begin{array}{c}\text { Verbos } \\
\text { estativos } \\
\text { descritivos } \\
\text { qualificativos }\end{array}$ & $\begin{array}{c}\text { Martins } \\
\text { (2004) }\end{array}$ & Descendente \\
\hline 318 & $/ \mathrm{ta} /$ & ta & $\begin{array}{c}\text { Ser meio } \\
\text { cozido; ser } \\
\text { ardido (ex. } \\
\text { pimenta) }\end{array}$ & $\begin{array}{c}\text { Verbos } \\
\text { estativos } \\
\text { descritivos } \\
\text { qualificativos }\end{array}$ & $\begin{array}{c}\text { Martins } \\
\text { (2004) }\end{array}$ & Atonal \\
\hline 319 & /pa?/ & pa & $\begin{array}{l}\text { Ser careca } \\
\text { só no meio } \\
\text { da cabeça }\end{array}$ & $\begin{array}{c}\text { Verbos } \\
\text { estativos } \\
\text { descritivos } \\
\text { qualificativos } \\
\end{array}$ & $\begin{array}{c}\text { Martins } \\
(2004)\end{array}$ & Atonal \\
\hline 320 & /nét/ & neet & $\begin{array}{l}\text { Ser raso } \\
\text { (ex. } \\
\text { igarapé) }\end{array}$ & $\begin{array}{c}\text { Verbos } \\
\text { estativos } \\
\text { descritivos } \\
\text { qualificativos }\end{array}$ & $\begin{array}{l}\text { Martins } \\
\text { (2004) }\end{array}$ & Ascendente \\
\hline 321 & /dup/ & dup & $\begin{array}{l}\text { Ser azedo } \\
\text { (ex. } \\
\text { banana- } \\
\text { maçã; } \\
\text { limão) } \\
\end{array}$ & $\begin{array}{c}\text { Verbos } \\
\text { estativos } \\
\text { descritivos } \\
\text { qualificativos }\end{array}$ & $\begin{array}{c}\text { Martins } \\
(2004)\end{array}$ & Atonal \\
\hline 322 & /ci/ & çi & Ser azedo & Verbo estativo & $\begin{array}{c}\text { Martins } \\
(2004)\end{array}$ & Atonal \\
\hline 323 & $/$ /Ry/ & ‘eng & Ser feio & $\begin{array}{c}\text { Verbos } \\
\text { estativos } \\
\text { descritivos } \\
\text { qualificativos }\end{array}$ & $\begin{array}{l}\text { Martins } \\
(2004)\end{array}$ & Atonal \\
\hline 324 & /dep/ & dep & $\begin{array}{l}\text { Ser gordo } \\
\text { (genérico) }\end{array}$ & $\begin{array}{c}\text { Verbos } \\
\text { estativos } \\
\text { descritivos } \\
\text { qualificativos }\end{array}$ & $\begin{array}{c}\text { Martins } \\
(2004)\end{array}$ & Atonal \\
\hline 325 & 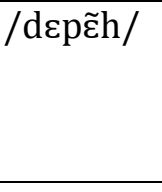 & depẽr & $\begin{array}{l}\text { Ser magro } \\
\text { e saudável' }\end{array}$ & $\begin{array}{c}\text { Verbos } \\
\text { estativos } \\
\text { descritivos } \\
\text { qualificativos } \\
\end{array}$ & $\begin{array}{c}\text { Martins } \\
\text { (2004) }\end{array}$ & Atonal \\
\hline 326 & /kàn/ & kaan & $\begin{array}{l}\text { Estar } \\
\text { úmido }\end{array}$ & $\begin{array}{c}\text { Verbos } \\
\text { estativos } \\
\text { descritivos } \\
\text { qualificativos }\end{array}$ & $\begin{array}{l}\text { Martins } \\
\text { (2004) }\end{array}$ & Descendente \\
\hline 327 & /we/ & wê & $\begin{array}{c}\text { Estar } \\
\text { molhado }\end{array}$ & $\begin{array}{c}\text { Verbos } \\
\text { estativos } \\
\text { descritivos } \\
\text { qualificativos }\end{array}$ & $\begin{array}{c}\text { Martins } \\
(2004)\end{array}$ & Atonal \\
\hline
\end{tabular}




\begin{tabular}{|c|c|c|c|c|c|c|}
\hline 328 & /cĩ/ & çĩ & $\begin{array}{c}\text { Estar } \\
\text { azedo, } \\
\text { estragado } \\
\text { (ex. comida } \\
\text { estragada) }\end{array}$ & $\begin{array}{c}\text { Verbos } \\
\text { estativos } \\
\text { descritivos } \\
\text { qualificativos }\end{array}$ & $\begin{array}{l}\text { Martins } \\
(2004)\end{array}$ & Atonal \\
\hline 329 & /lòł/ & ‘ôoj & $\begin{array}{l}\text { Estar cheio } \\
\text { para } \\
\text { objetos } \\
\text { rasos e } \\
\text { circulares } \\
\text { (ex. prato) } \\
\end{array}$ & $\begin{array}{c}\text { Verbos } \\
\text { estativos } \\
\text { descritivos } \\
\text { qualificativos }\end{array}$ & $\begin{array}{c}\text { Martins } \\
(2004)\end{array}$ & Descendente \\
\hline 330 & /Row/ & 'ôw & $\begin{array}{c}\text { Estar cheio } \\
\text { para } \\
\text { objetos } \\
\text { fundos } \\
\end{array}$ & $\begin{array}{c}\text { Verbos } \\
\text { estativos } \\
\text { descritivos } \\
\text { qualificativos } \\
\end{array}$ & $\begin{array}{c}\text { Martins } \\
(2004)\end{array}$ & Atonal \\
\hline 331 & /meh/ & mêr & $\begin{array}{c}\text { Estar } \\
\text { cheiroso }\end{array}$ & $\begin{array}{c}\text { Verbos } \\
\text { estativos } \\
\text { descritivos } \\
\text { qualificativos }\end{array}$ & $\begin{array}{c}\text { Martins } \\
(2004)\end{array}$ & Atonal \\
\hline 332 & $/ / \tilde{\varepsilon} \mathrm{n}^{2} /$ & “ẽn & $\begin{array}{l}\text { Estar } \\
\text { frouxo }\end{array}$ & $\begin{array}{c}\text { Verbos } \\
\text { estativos } \\
\text { descritivos } \\
\text { qualificativos }\end{array}$ & $\begin{array}{l}\text { Martins } \\
(2004)\end{array}$ & Atonal \\
\hline 333 & /R̂́k/ & Tik & $\begin{array}{c}\text { Estar } \\
\text { inchado }\end{array}$ & $\begin{array}{c}\text { Verbos } \\
\text { estativos } \\
\text { descritivos } \\
\text { qualificativos }\end{array}$ & $\begin{array}{c}\text { Martins } \\
(2004)\end{array}$ & Descendente \\
\hline 334 & $/ w^{2} \gamma w /$ & w'âw & $\begin{array}{c}\text { Estar } \\
\text { magro de } \\
\text { doente }\end{array}$ & $\begin{array}{c}\text { Verbos } \\
\text { estativos } \\
\text { descritivos } \\
\text { qualificativos }\end{array}$ & $\begin{array}{c}\text { Martins } \\
(2004)\end{array}$ & Atonal \\
\hline 335 & /lo?/ & lô' & $\begin{array}{l}\text { Galho que } \\
\text { está torto, } \\
\text { inclinado } \\
\text { desde o pé }\end{array}$ & $\begin{array}{c}\text { Verbos } \\
\text { estativos } \\
\text { descritivos } \\
\text { posicionais }\end{array}$ & $\begin{array}{l}\text { Martins } \\
(2004)\end{array}$ & Atonal \\
\hline 336 & /jãn/ & yãn & $\begin{array}{c}\text { Estar } \\
\text { envergado } \\
\text { por causa } \\
\text { do peso } \\
\text { (ex. cacho } \\
\text { de banana } \\
\text { muito } \\
\text { pesado na } \\
\text { bananeira) } \\
\end{array}$ & $\begin{array}{c}\text { Verbos } \\
\text { estativos } \\
\text { descritivos } \\
\text { posicionais }\end{array}$ & $\begin{array}{l}\text { Martins } \\
(2004)\end{array}$ & Atonal \\
\hline 337 & /lep/ & lêp & $\begin{array}{c}\text { Estar } \\
\text { encolhido } \\
\text { como uma } \\
\text { bola por } \\
\text { causa do } \\
\text { frio } \\
\end{array}$ & $\begin{array}{c}\text { Verbos } \\
\text { estativos } \\
\text { descritivos } \\
\text { posicionais }\end{array}$ & $\begin{array}{l}\text { Martins } \\
(2004)\end{array}$ & Atonal \\
\hline 338 & /ja?/ & ya' & Assar & $\begin{array}{c}\text { Verbo } \\
\text { transitivo }\end{array}$ & $\begin{array}{c}\text { Martins } \\
(2004) \\
\end{array}$ & Atonal \\
\hline 339 & 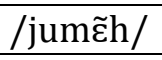 & yumẽr & Estar & Verbo estativo & Martins & Atonal \\
\hline
\end{tabular}




\begin{tabular}{|c|c|c|c|c|c|c|}
\hline & & & doente & $\begin{array}{c}\text { descritivo } \\
\text { qualificativos }\end{array}$ & $(2004)$ & \\
\hline 340 & /kaj/ & kas & Ser velho & $\begin{array}{c}\text { Verbo estativo } \\
\text { descritivo }\end{array}$ & $\begin{array}{l}\text { Martins } \\
(2004)\end{array}$ & Atonal \\
\hline 341 & /kŕh/ & kâar & $\begin{array}{c}\text { Ser } \\
\text { sofredor }\end{array}$ & $\begin{array}{l}\text { Verbo estativo } \\
\text { descritivo }\end{array}$ & $\begin{array}{l}\text { Martins } \\
(2004)\end{array}$ & Atonal \\
\hline 342 & /loj/ & lôy & $\begin{array}{c}\text { Ser } \\
\text { curvado }\end{array}$ & $\begin{array}{c}\text { Verbo estativo } \\
\text { descritivo } \\
\text { atributivo } \\
\end{array}$ & $\begin{array}{l}\text { Martins } \\
(2004)\end{array}$ & Atonal \\
\hline 343 & /lo?/ & lô' & $\begin{array}{c}\text { Ser } \\
\text { curvado }\end{array}$ & $\begin{array}{c}\text { Verbo estativo } \\
\text { descritivo } \\
\text { atributivo }\end{array}$ & $\begin{array}{c}\text { Martins } \\
(2004)\end{array}$ & Atonal \\
\hline 344 & $\mathrm{bcb}$ & beb & $\begin{array}{c}\text { Ser } \\
\text { achatado } \\
\text { para coisas } \\
\text { redondas } \\
\text { (ex. prato, } \\
\text { bacia, forno } \\
\text { de torrar } \\
\text { farinha) }\end{array}$ & $\begin{array}{c}\text { Verbo estativo } \\
\text { descritivo } \\
\text { atributivo }\end{array}$ & $\begin{array}{l}\text { Martins } \\
(2004)\end{array}$ & Atonal \\
\hline 345 & /bem/ & bên & $\begin{array}{l}\text { Ser grosso } \\
\text { e espesso } \\
\text { (ex. lábios } \\
\text { inchados) }\end{array}$ & $\begin{array}{c}\text { Verbo estativo } \\
\text { descritivo } \\
\text { atributivo }\end{array}$ & $\begin{array}{l}\text { Martins } \\
(2004)\end{array}$ & Atonal \\
\hline 346 & 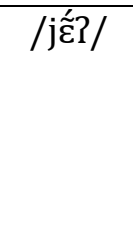 & yẽe' & $\begin{array}{c}\text { Ser } \\
\text { pequeno e } \\
\text { apertado } \\
\text { (ex. tipo de } \\
\text { nariz) }\end{array}$ & $\begin{array}{c}\text { Verbo estativo } \\
\text { descritivo } \\
\text { atributivo }\end{array}$ & $\begin{array}{l}\text { Martins } \\
(2004)\end{array}$ & Descendente \\
\hline 347 & /dic/ & dic & $\begin{array}{l}\text { Ser } \\
\text { pequeno, } \\
\text { ser } \\
\text { mirrado } \\
\end{array}$ & Verbo estativo & $\begin{array}{l}\text { Martins } \\
(2004)\end{array}$ & Atonal \\
\hline 348 & /RE?/ & 'e & $\begin{array}{c}\text { Ser } \\
\text { apertado } \\
\text { (ex. roupa } \\
\text { apertada } \\
\text { no corpo) }\end{array}$ & $\begin{array}{c}\text { Verbo estativo } \\
\text { descritivo } \\
\text { atributivo }\end{array}$ & $\begin{array}{c}\text { Martins } \\
(2004)\end{array}$ & Atonal \\
\hline 349 & $/ \mathrm{Rej}_{\mathrm{f}} /$ & 'ej & $\begin{array}{l}\text { Ser baixo e } \\
\text { pequeno }\end{array}$ & $\begin{array}{c}\text { Verbo estativo } \\
\text { descritivo } \\
\text { atributivo }\end{array}$ & $\begin{array}{l}\text { Martins } \\
(2004)\end{array}$ & Atonal \\
\hline 350 & /win/ & win & $\begin{array}{l}\text { Ser fino e } \\
\text { cumprido }\end{array}$ & $\begin{array}{c}\text { Verbo estativo } \\
\text { descritivo } \\
\text { atributivo }\end{array}$ & $\begin{array}{l}\text { Martins } \\
\text { (2004) }\end{array}$ & Atonal \\
\hline 351 & /Rab/ & 'ab & $\begin{array}{c}\text { Ser grande } \\
\text { para coisas } \\
\text { redondas } \\
\text { (ex. } \\
\text { nádegas) }\end{array}$ & $\begin{array}{c}\text { Verbo estativo } \\
\text { descritivo } \\
\text { atributivo }\end{array}$ & $\begin{array}{l}\text { Martins } \\
(2004)\end{array}$ & Atonal \\
\hline 352 & /2rb/ & 'âb & $\begin{array}{l}\text { Ser grande } \\
\text { (só para } \\
\text { cachos de } \\
\text { frutas) }\end{array}$ & $\begin{array}{c}\text { Verbo estativo } \\
\text { descritivo } \\
\text { atributivo }\end{array}$ & $\begin{array}{l}\text { Martins } \\
(2004)\end{array}$ & Atonal \\
\hline
\end{tabular}




\begin{tabular}{|c|c|c|c|c|c|c|}
\hline 353 & $/ \mathrm{R \gamma d} /$ & 'âd & $\begin{array}{l}\text { Ser grande } \\
\text { e largo (ex. } \\
\text { gente, } \\
\text { aturá) }\end{array}$ & $\begin{array}{c}\text { Verbo estativo } \\
\text { descritivo } \\
\text { atributivo }\end{array}$ & $\begin{array}{l}\text { Martins } \\
\text { (2004) }\end{array}$ & Atonal \\
\hline 354 & /RE?/ & ‘e & $\begin{array}{l}\text { Ser grande } \\
\text { e redondo } \\
\text { (ex. boca, } \\
\text { panela) }\end{array}$ & $\begin{array}{c}\text { Verbo estativo } \\
\text { descritivo } \\
\text { atributivo }\end{array}$ & $\begin{array}{l}\text { Martins } \\
\text { (2004) }\end{array}$ & Atonal \\
\hline 355 & $/ R \varepsilon ? /$ & 'e & $\begin{array}{l}\text { Ser grande } \\
\text { e oco }\end{array}$ & & $\begin{array}{c}\text { Martins } \\
(2004)\end{array}$ & Atonal \\
\hline 356 & $/ w^{3}{ }^{2}$ / & w'o' $^{\prime}$ & $\begin{array}{l}\text { Ser grande } \\
\text { largo no } \\
\text { corpo (ex. } \\
\text { roupa) }\end{array}$ & $\begin{array}{c}\text { Verbo estativo } \\
\text { descritivo } \\
\text { atributivo }\end{array}$ & $\begin{array}{l}\text { Martins } \\
(2004)\end{array}$ & Atonal \\
\hline 357 & /héh/ & rêer & $\begin{array}{l}\text { Ser grande } \\
\text { e largo (ex. } \\
\text { tórax) }\end{array}$ & $\begin{array}{c}\text { Verbo estativo } \\
\text { descritivo } \\
\text { atributivo }\end{array}$ & $\begin{array}{l}\text { Martins } \\
(2004)\end{array}$ & Descendente \\
\hline 358 & /lo?/ & lo' & $\begin{array}{l}\text { Ser grande } \\
\text { para pés e } \\
\text { mãos no } \\
\text { dialeto } \\
\text { feminino }\end{array}$ & $\begin{array}{c}\text { Verbo estativo } \\
\text { descritivo } \\
\text { atributivo }\end{array}$ & $\begin{array}{l}\text { Martins } \\
\text { (2004) }\end{array}$ & Atonal \\
\hline 359 & /lof/ & loj & $\begin{array}{l}\text { Ser grande } \\
\text { para coisas } \\
\text { cilíndricas } \\
\text { (ex. tronco) }\end{array}$ & $\begin{array}{c}\text { Verbo estativo } \\
\text { descritivo } \\
\text { atributivo }\end{array}$ & $\begin{array}{l}\text { Martins } \\
(2004)\end{array}$ & Atonal \\
\hline 360 & /Rod/ & 'od & Ser gordo & $\begin{array}{c}\text { Verbo estativo } \\
\text { descritivo } \\
\text { atributivo }\end{array}$ & $\begin{array}{l}\text { Martins } \\
(2004)\end{array}$ & Atonal \\
\hline 361 & /n? umm$^{2} /$ & $\mathrm{n}^{\prime} \tilde{\mathrm{um}}{ }^{\prime}$ & $\begin{array}{c}\text { Ser gordo e } \\
\text { largo, } \\
\text { achatado } \\
\text { (ex. dedo } \\
\text { polegar) }\end{array}$ & $\begin{array}{c}\text { Verbo estativo } \\
\text { descritivo } \\
\text { atributivo }\end{array}$ & $\begin{array}{l}\text { Martins } \\
\text { (2004) }\end{array}$ & Atonal \\
\hline 362 & /bef/ & bes & $\begin{array}{l}\text { Ser gordo e } \\
\quad \text { largo }\end{array}$ & $\begin{array}{c}\text { Verbo estativo } \\
\text { descritivo } \\
\text { atributivo }\end{array}$ & $\begin{array}{c}\text { Martins } \\
(2004)\end{array}$ & Atonal \\
\hline 363 & /dut/ & dut & $\begin{array}{l}\text { Ser gordo e } \\
\text { baixo }\end{array}$ & $\begin{array}{c}\text { Verbo estativo } \\
\text { descritivo } \\
\text { atributivo } \\
\end{array}$ & $\begin{array}{l}\text { Martins } \\
(2004)\end{array}$ & Atonal \\
\hline 364 & /béw/ & bêew & $\begin{array}{c}\text { Gordo e } \\
\text { arredondad } \\
\text { o (só para } \\
\text { bebê) }\end{array}$ & $\begin{array}{c}\text { Verbo estativo } \\
\text { descritivo } \\
\text { atributivo }\end{array}$ & $\begin{array}{l}\text { Martins } \\
(2004)\end{array}$ & Descendente \\
\hline 365 & /m触? & mẽew' & $\begin{array}{c}\text { Ser gordo e } \\
\text { bem } \\
\text { baixinho; } \\
\text { ser bem } \\
\text { achatado }\end{array}$ & $\begin{array}{c}\text { Verbo estativo } \\
\text { descritivo } \\
\text { atributivo }\end{array}$ & $\begin{array}{l}\text { Martins } \\
\text { (2004) }\end{array}$ & Descendente \\
\hline 366 & $/ \mathrm{pe} \int /$ & pês & $\begin{array}{c}\text { Grosso e } \\
\text { largo }\end{array}$ & $\begin{array}{c}\text { Verbo estativo } \\
\text { descritivo }\end{array}$ & $\begin{array}{l}\text { Martins } \\
\text { (2004) }\end{array}$ & Atonal \\
\hline
\end{tabular}




\begin{tabular}{|c|c|c|c|c|c|c|}
\hline & & & & atributivo & & \\
\hline 367 & /lub/ & lub & $\begin{array}{c}\text { Grosso } \\
\text { para coisas } \\
\text { cilíndricas } \\
\text { (ex. cipó, } \\
\text { cabelo, } \\
\text { pau) }\end{array}$ & $\begin{array}{c}\text { Verbo estativo } \\
\text { descritivo } \\
\text { atributivo }\end{array}$ & $\begin{array}{l}\text { Martins } \\
(2004)\end{array}$ & Atonal \\
\hline 368 & 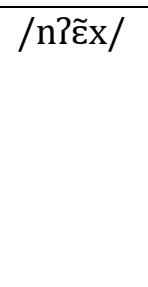 & n'ẽx & $\begin{array}{c}\text { Grosso } \\
\text { para coisas } \\
\text { líquidas } \\
\text { (ex. } \\
\text { mingau, } \\
\text { lama) }\end{array}$ & $\begin{array}{c}\text { Verbo estativo } \\
\text { descritivo } \\
\text { atributivo }\end{array}$ & $\begin{array}{c}\text { Martins } \\
\text { (2004) }\end{array}$ & Atonal \\
\hline 369 & /pũn/ & 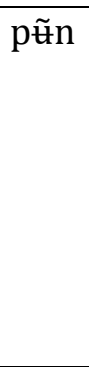 & $\begin{array}{c}\text { Mais } \\
\text { grosso para } \\
\text { coisas } \\
\text { líquidas } \\
\text { (ex. vinho } \\
\text { de } \\
\text { pupunha, } \\
\text { açaí, lama) }\end{array}$ & $\begin{array}{c}\text { Verbo estativo } \\
\text { descritivo } \\
\text { atributivo }\end{array}$ & $\begin{array}{l}\text { Martins } \\
(2004)\end{array}$ & Atonal \\
\hline 370 & /bunn? & bun' & $\begin{array}{l}\text { Ser } \\
\text { comprido e } \\
\text { grosso }\end{array}$ & $\begin{array}{c}\text { Verbo estativo } \\
\text { descritivo } \\
\text { atributivo }\end{array}$ & $\begin{array}{l}\text { Martins } \\
(2004)\end{array}$ & Atonal \\
\hline 371 & /brp/ & bâp & $\begin{array}{c}\text { Grosso só } \\
\text { para lábios }\end{array}$ & $\begin{array}{c}\text { Verbo estativo } \\
\text { descritivo } \\
\text { atributivo }\end{array}$ & $\begin{array}{c}\text { Martins } \\
(2004)\end{array}$ & Atonal \\
\hline 372 & /lãk/ & lãk & $\begin{array}{c}\text { Ser } \\
\text { redondo e } \\
\text { descampad } \\
\text { o (ex. } \\
\text { buraco de } \\
\text { cobra } \\
\text { caranguejo } \\
\text { ) }\end{array}$ & $\begin{array}{l}\text { Verbo estativo } \\
\text { descritivo } \\
\text { atributivo }\end{array}$ & $\begin{array}{l}\text { Martins } \\
(2004)\end{array}$ & Atonal \\
\hline 373 & /luk/ & luk & $\begin{array}{c}\text { Ser bem } \\
\text { redondo } \\
\text { (ex. cabelo } \\
\text { enrolado; } \\
\text { ter caroço } \\
\text { grande) }\end{array}$ & $\begin{array}{c}\text { Verbo estativo } \\
\text { descritivo } \\
\text { atributivo }\end{array}$ & $\begin{array}{l}\text { Martins } \\
(2004)\end{array}$ & Atonal \\
\hline 374 & /lok/ & lok & $\begin{array}{c}\text { Ser } \\
\text { redondo } \\
\text { com } \\
\text { perfuração } \\
\text { grande (ex. } \\
\text { buraco de } \\
\text { onça ou } \\
\text { cutia) }\end{array}$ & $\begin{array}{c}\text { Verbo estativo } \\
\text { descritivo } \\
\text { atributivo }\end{array}$ & $\begin{array}{l}\text { Martins } \\
(2004)\end{array}$ & Atonal \\
\hline 375 & /lãk/ & lõk & Ser & Verbo estativo & Martins & Atonal \\
\hline
\end{tabular}




\begin{tabular}{|c|c|c|c|c|c|c|}
\hline & & & $\begin{array}{l}\text { redondo } \\
\text { com } \\
\text { perfuração } \\
\text { pequena } \\
\text { (ex. buraco } \\
\text { de cutiara) }\end{array}$ & $\begin{array}{l}\text { descritivo } \\
\text { atributivo }\end{array}$ & (2004) & \\
\hline 376 & /low/ & lôw & $\begin{array}{c}\text { Ser } \\
\text { redondo de } \\
\text { grande } \\
\text { diâmetro } \\
\text { (ex. } \\
\text { cisterna, } \\
\text { barriga) }\end{array}$ & $\begin{array}{c}\text { Verbo estativo } \\
\text { descritivo } \\
\text { atributivo }\end{array}$ & $\begin{array}{c}\text { Martins } \\
\text { (2004) }\end{array}$ & Atonal \\
\hline 377 & $/$ lew $^{2} /$ & lêw' & $\begin{array}{c}\text { Ser } \\
\text { redondo e } \\
\text { grosso (ex. } \\
\text { nó de } \\
\text { corda, de } \\
\text { cipó) }\end{array}$ & $\begin{array}{c}\text { Verbo estativo } \\
\text { descritivo } \\
\text { atributivo }\end{array}$ & $\begin{array}{c}\text { Martins } \\
\text { (2004) }\end{array}$ & Atonal \\
\hline 378 & /lĩm? & lĩm' & $\begin{array}{c}\text { Ser } \\
\text { redondo e } \\
\text { bem } \\
\text { pequeno } \\
\text { (ex. } \\
\text { minhoca } \\
\text { enrolada } \\
\text { em folha) }\end{array}$ & $\begin{array}{c}\text { Verbo estativo } \\
\text { descritivo } \\
\text { atributivo }\end{array}$ & $\begin{array}{c}\text { Martins } \\
\text { (2004) }\end{array}$ & Atonal \\
\hline 379 & /lem/ & lêm & $\begin{array}{c}\text { Ser } \\
\text { redondo de } \\
\text { pequeno } \\
\text { diâmetro } \\
\text { (ex. jabuti, } \\
\text { cabeça do } \\
\text { microfone) } \\
\end{array}$ & $\begin{array}{c}\text { Verbo estativo } \\
\text { descritivo } \\
\text { atributivo }\end{array}$ & $\begin{array}{c}\text { Martins } \\
\text { (2004) }\end{array}$ & Atonal \\
\hline 380 & /muim/ & $\mathrm{mtm}$ & $\begin{array}{c}\text { Ser } \\
\text { redondo e } \\
\text { bem } \\
\text { pequeno } \\
\text { (ex. } \\
\text { verruga) } \\
\end{array}$ & $\begin{array}{c}\text { Verbo estativo } \\
\text { descritivo } \\
\text { atributivo }\end{array}$ & $\begin{array}{c}\text { Martins } \\
\text { (2004) }\end{array}$ & Atonal \\
\hline 381 & /RE?/ & 'e & $\begin{array}{c}\text { Ser } \\
\text { arredondad } \\
\text { o e ir se } \\
\text { estreitando } \\
\text { (ex. } \\
\text { pandeiro) } \\
\end{array}$ & $\begin{array}{c}\text { Verbo estativo } \\
\text { descritivo } \\
\text { atributivo }\end{array}$ & $\begin{array}{c}\text { Martins } \\
\text { (2004) }\end{array}$ & Atonal \\
\hline 382 & /Ro?/ & 'o & $\begin{array}{c}\text { Ser } \\
\text { redondo e } \\
\text { grande (ex. } \\
\text { boca } \\
\text { aberta; }\end{array}$ & $\begin{array}{c}\text { Verbo estativo } \\
\text { descritivo } \\
\text { atributivo }\end{array}$ & $\begin{array}{c}\text { Martins } \\
(2004)\end{array}$ & Atonal \\
\hline
\end{tabular}




\begin{tabular}{|c|c|c|c|c|c|c|}
\hline & & & $\begin{array}{c}\text { panela } \\
\text { grande por } \\
\text { inteiro) }\end{array}$ & & & \\
\hline 383 & /Ro?/ & 'o & $\begin{array}{c}\text { Arrancar a } \\
\text { unha }\end{array}$ & $\begin{array}{c}\text { Não } \\
\text { classificado por } \\
\text { Martins }\end{array}$ & $\begin{array}{l}\text { Martins } \\
\text { (2004) }\end{array}$ & Atonal \\
\hline 384 & /nem/ & nêm & $\begin{array}{l}\text { Ser esférico } \\
\text { (ex. concha, } \\
\text { panela, } \\
\text { cabeça, } \\
\text { caroço de } \\
\text { açaí) }\end{array}$ & $\begin{array}{c}\text { Verbo estativo } \\
\text { descritivo } \\
\text { atributivo }\end{array}$ & $\begin{array}{l}\text { Martins } \\
\text { (2004) }\end{array}$ & Atonal \\
\hline 385 & /nũh lãk/ & nũr lãk & $\begin{array}{l}\text { Cabeça que } \\
\text { está pelada } \\
\text { só no meio }\end{array}$ & $\begin{array}{c}\text { Verbo estativo } \\
\text { descritivo } \\
\text { atributivo }\end{array}$ & $\begin{array}{c}\text { Martins } \\
\text { (2004) }\end{array}$ & Atonal \\
\hline 386 & /nũh le?/ & nũr le' & $\begin{array}{l}\text { Cabeça que } \\
\text { está quase } \\
\text { careca }\end{array}$ & $\begin{array}{c}\text { Verbo estativo } \\
\text { descritivo } \\
\text { atributivo }\end{array}$ & $\begin{array}{c}\text { Martins } \\
\text { (2004) }\end{array}$ & Atonal \\
\hline 387 & /nũh lãk/ & nũr lãk & $\begin{array}{l}\text { Cabeça que } \\
\text { está pelada } \\
\text { só no meio } \\
\end{array}$ & $\begin{array}{c}\text { Verbo estativo } \\
\text { descritivo } \\
\text { atributivo } \\
\end{array}$ & $\begin{array}{l}\text { Martins } \\
\text { (2004) }\end{array}$ & Atonal \\
\hline 388 & /nũh wãk/ & nũr wãk & $\begin{array}{l}\text { Cabeça que } \\
\text { está toda } \\
\text { pelada }\end{array}$ & $\begin{array}{c}\text { Verbo estativo } \\
\text { descritivo } \\
\text { atributivo } \\
\end{array}$ & $\begin{array}{c}\text { Martins } \\
\text { (2004) }\end{array}$ & Atonal \\
\hline 389 & /wirt/ & w'ât & $\begin{array}{c}\text { Ser } \\
\text { comprido } \\
\text { (genérico) }\end{array}$ & $\begin{array}{c}\text { Verbo estativo } \\
\text { descritivo } \\
\text { atributivo }\end{array}$ & $\begin{array}{c}\text { Martins } \\
(2004)\end{array}$ & Atonal \\
\hline 390 & /win/ & win & $\begin{array}{c}\text { Ser } \\
\text { comprido e } \\
\text { fino (ex. } \\
\text { pau, gente, } \\
\text { roupa bem } \\
\text { apertada } \\
\text { no corpo) }\end{array}$ & $\begin{array}{c}\text { Verbo estativo } \\
\text { descritivo } \\
\text { atributivo }\end{array}$ & $\begin{array}{l}\text { Martins } \\
\text { (2004) }\end{array}$ & Atonal \\
\hline 391 & /wag/ & wag & $\begin{array}{c}\text { Ser } \\
\text { comprido e } \\
\text { um pouco } \\
\text { largo (ex. } \\
\text { gente alta e } \\
\text { um pouco } \\
\text { gorda) }\end{array}$ & $\begin{array}{c}\text { Verbo estativo } \\
\text { descritivo } \\
\text { atributivo }\end{array}$ & $\begin{array}{l}\text { Martins } \\
\text { (2004) }\end{array}$ & Atonal \\
\hline 392 & /waj ${ }^{3} /$ & way' & $\begin{array}{l}\text { Ser bem } \\
\text { comprido } \\
\text { (ex. pessoa } \\
\text { muito alta) }\end{array}$ & $\begin{array}{l}\text { Verbo estativo } \\
\text { descritivo } \\
\text { atributivo }\end{array}$ & $\begin{array}{l}\text { Martins } \\
(2004)\end{array}$ & Atonal \\
\hline 393 & /w $\tilde{\varepsilon} \int /$ & wẽs & $\begin{array}{c}\text { Ser } \\
\text { comprido e } \\
\text { muito (ex. } \\
\text { cabelo) } \\
\end{array}$ & $\begin{array}{l}\text { Verbo estativo } \\
\text { descritivo } \\
\text { atributivo }\end{array}$ & $\begin{array}{c}\text { Martins } \\
(2004)\end{array}$ & Atonal \\
\hline 394 & $/ \mathrm{w} \tilde{\varepsilon} \mathrm{w}^{?} /$ & wẽw' & $\begin{array}{c}\text { Ser } \\
\text { comprido e } \\
\text { pouco (ex. }\end{array}$ & $\begin{array}{c}\text { Verbo estativo } \\
\text { descritivo } \\
\text { atributivo }\end{array}$ & $\begin{array}{c}\text { Martins } \\
(2004)\end{array}$ & Atonal \\
\hline
\end{tabular}




\begin{tabular}{|c|c|c|c|c|c|c|}
\hline & & & $\begin{array}{l}\text { púbis e } \\
\text { barba) }\end{array}$ & & & \\
\hline 395 & /wog/ & wog & $\begin{array}{c}\text { Ser } \\
\text { exagerada } \\
\text { mente } \\
\text { comprido } \\
\text { (ex. roupa } \\
\text { grande no } \\
\text { corpo) } \\
\end{array}$ & $\begin{array}{c}\text { Verbo estativo } \\
\text { descritivo } \\
\text { atributivo }\end{array}$ & $\begin{array}{c}\text { Martins } \\
\text { (2004) }\end{array}$ & Atonal \\
\hline 396 & /wog/ & wog & Ser grande & Verbo estativo & $\begin{array}{c}\text { Martins } \\
\text { (2004) }\end{array}$ & Atonal \\
\hline 397 & /wút/ & wuut & $\begin{array}{c}\text { Ser } \\
\text { comprido e } \\
\text { muito fino } \\
\text { (ex. cabelo, } \\
\text { púbis e } \\
\text { barba) } \\
\end{array}$ & $\begin{array}{c}\text { Verbo estativo } \\
\text { descritivo } \\
\text { atributivo }\end{array}$ & $\begin{array}{l}\text { Martins } \\
\text { (2004) }\end{array}$ & Descendente \\
\hline 398 & /W? $\mathrm{P}$ ? $/$ & $\mathrm{w}^{\prime} \mathrm{o}^{\prime}$ & $\begin{array}{c}\text { Ser } \\
\text { comprido e } \\
\text { exagerada } \\
\text { mente } \\
\text { largo (ex. } \\
\text { tira larga; } \\
\text { roupa } \\
\text { comprida e } \\
\text { larga no } \\
\text { corpo) } \\
\end{array}$ & $\begin{array}{c}\text { Verbo estativo } \\
\text { descritivo } \\
\text { atributivo }\end{array}$ & $\begin{array}{c}\text { Martins } \\
\text { (2004) }\end{array}$ & Atonal \\
\hline 399 & /wi?/ & wi' & $\begin{array}{c}\text { Ser } \\
\text { comprido e } \\
\text { bem } \\
\text { estreito } \\
\text { (ex. pessoa } \\
\text { muito } \\
\text { magricela e } \\
\text { alta) } \\
\end{array}$ & $\begin{array}{c}\text { Verbo estativo } \\
\text { descritivo } \\
\text { atributivo }\end{array}$ & $\begin{array}{c}\text { Martins } \\
\text { (2004) }\end{array}$ & Atonal \\
\hline 400 & /win/ & win & $\begin{array}{c}\text { Ser } \\
\text { comprido e } \\
\text { fino (ex. } \\
\text { pau, gente, } \\
\text { roupa } \\
\text { pequena e } \\
\text { bem } \\
\text { apertada) }\end{array}$ & $\begin{array}{c}\text { Verbo estativo } \\
\text { descritivo } \\
\text { atributivo }\end{array}$ & $\begin{array}{l}\text { Martins } \\
\text { (2004) }\end{array}$ & Atonal \\
\hline 401 & /xin/ & xin & $\begin{array}{c}\text { Ser } \\
\text { comprido } \\
\text { como } \\
\text { rastro de } \\
\text { jacaré (ex. } \\
\text { sinal de } \\
\text { arranhado) }\end{array}$ & $\begin{array}{c}\text { Verbo estativo } \\
\text { descritivo } \\
\text { atributivo }\end{array}$ & $\begin{array}{c}\text { Martins } \\
\text { (2004) }\end{array}$ & Atonal \\
\hline 402 & /xig/ & xig & $\begin{array}{c}\text { Ser } \\
\text { comprido e } \\
\text { estreito } \\
\end{array}$ & $\begin{array}{c}\text { Verbo estativo } \\
\text { descritivo } \\
\text { atributivo } \\
\end{array}$ & $\begin{array}{c}\text { Martins } \\
\text { (2004) }\end{array}$ & Atonal \\
\hline
\end{tabular}




\begin{tabular}{|c|c|c|c|c|c|c|}
\hline & & & $\begin{array}{l}\text { (ex. gente } \\
\text { magra e } \\
\text { alta } \\
\end{array}$ & & & \\
\hline 403 & /mow/ & môw & $\begin{array}{c}\text { Ser } \\
\text { comprido } \\
\text { só para fios }\end{array}$ & $\begin{array}{c}\text { Verbo estativo } \\
\text { descritivo } \\
\text { atributivo }\end{array}$ & $\begin{array}{c}\text { Martins } \\
\text { (2004) }\end{array}$ & Atonal \\
\hline 404 & $/ \mathrm{m} \jmath \mathrm{j} /$ & moy & $\begin{array}{c}\text { Ser } \\
\text { comprido } \\
\text { (só para } \\
\text { criança) }\end{array}$ & $\begin{array}{c}\text { Verbo estativo } \\
\text { descritivo } \\
\text { atributivo }\end{array}$ & $\begin{array}{c}\text { Martins } \\
\text { (2004) }\end{array}$ & Atonal \\
\hline 405 & $/ \mathrm{mok} /$ & mok & $\begin{array}{c}\text { Ser } \\
\text { comprido e } \\
\text { largo (ex. } \\
\text { roupa, } \\
\text { cobertor) }\end{array}$ & $\begin{array}{c}\text { Verbo estativo } \\
\text { descritivo } \\
\text { atributivo }\end{array}$ & $\begin{array}{c}\text { Martins } \\
\text { (2004) }\end{array}$ & Atonal \\
\hline 406 & /lep/ & lêp & $\begin{array}{c}\text { Estar } \\
\text { encolhido } \\
\text { como bola } \\
\text { por causa } \\
\text { do frio }\end{array}$ & $\begin{array}{c}\text { Verbo estativo } \\
\text { descritivo } \\
\text { atributivo }\end{array}$ & $\begin{array}{c}\text { Martins } \\
\text { (2004) }\end{array}$ & Atonal \\
\hline 407 & /low/ & lôw & $\begin{array}{c}\text { Ser } \\
\text { redondo de } \\
\text { diâmetro } \\
\text { grande (ex. } \\
\text { cisterna, } \\
\text { barriga } \\
\text { grande) }\end{array}$ & $\begin{array}{c}\text { Verbo estativo } \\
\text { descritivo } \\
\text { atributivo }\end{array}$ & $\begin{array}{c}\text { Martins } \\
\text { (2004) }\end{array}$ & Atonal \\
\hline 408 & /Rĩw? & '̃̃w' & $\begin{array}{c}\text { Ser } \\
\text { apertado } \\
\text { no corpo }\end{array}$ & $\begin{array}{c}\text { Verbo estativo } \\
\text { descritivo } \\
\text { atributivo }\end{array}$ & $\begin{array}{c}\text { Martins } \\
\text { (2004) }\end{array}$ & Atonal \\
\hline 409 & /ك̌̀ł-n?û́k/ & 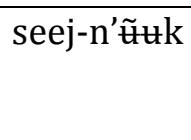 & $\begin{array}{l}\text { Ser maneta } \\
\text { ou perneta }\end{array}$ & $\begin{array}{c}\text { Verbo estativo } \\
\text { descritivo } \\
\text { atributivo }\end{array}$ & $\begin{array}{c}\text { Martins } \\
\text { (2004) }\end{array}$ & $\begin{array}{l}\text { Construção } \\
\text { com mais de } \\
\text { um tom }\end{array}$ \\
\hline 410 & /nem/ & nêm & $\begin{array}{c}\text { Ser } \\
\text { redondo } \\
\text { (ex. prato, } \\
\text { concha, } \\
\text { cabeça, } \\
\text { panela) }\end{array}$ & $\begin{array}{c}\text { Verbo estativo } \\
\text { descritivo } \\
\text { atributivo }\end{array}$ & $\begin{array}{l}\text { Martins } \\
\text { (2004) }\end{array}$ & Atonal \\
\hline 411 & /nèm/ & nêem & $\begin{array}{l}\text { Arredondar } \\
\text {, dobrar } \\
\text { afunilando } \\
\text { (ex. dobrar } \\
\text { peixe ou } \\
\text { minhoca na } \\
\text { folha) }\end{array}$ & Verbo ativo & $\begin{array}{c}\text { Martins } \\
\text { (2004) }\end{array}$ & Descendente \\
\hline 412 & /Sok/ & sôk & $\begin{array}{c}\text { Estar } \\
\text { amontoado } \\
\text { (monte de } \\
\text { folhas) }\end{array}$ & $\begin{array}{c}\text { Verbo estativo } \\
\text { descritivo } \\
\text { atributivo }\end{array}$ & $\begin{array}{c}\text { Martins } \\
\text { (2004) }\end{array}$ & Atonal \\
\hline 413 & /Sók/ & sôok & $\begin{array}{l}\text { Amontoar } \\
\text { (frutas, }\end{array}$ & Verbo ativo & $\begin{array}{l}\text { Martins } \\
(2004)\end{array}$ & Descendente \\
\hline
\end{tabular}




\begin{tabular}{|c|c|c|c|c|c|c|}
\hline & & & folhas etc) & & & \\
\hline 414 & /lok/ & lôk & $\begin{array}{l}\text { Ter buraco } \\
\text { redondo e } \\
\text { grande que } \\
\text { vara do } \\
\text { outro lado }\end{array}$ & $\begin{array}{c}\text { Verbo estativo } \\
\text { descritivo } \\
\text { atributivo }\end{array}$ & $\begin{array}{l}\text { Martins } \\
\text { (2004) }\end{array}$ & Atonal \\
\hline 415 & $/$ /Rd/ & ‘ed & $\begin{array}{c}\text { Ser sem } \\
\text { equilíbrio }\end{array}$ & $\begin{array}{c}\text { Verbo estativo } \\
\text { descritivo } \\
\text { atributivo } \\
\end{array}$ & $\begin{array}{l}\text { Martins } \\
\text { (2004) }\end{array}$ & Atonal \\
\hline 416 & /१غ̀d/ & ‘eed & $\begin{array}{l}\text { Virar (pau, } \\
\text { gente) }\end{array}$ & Verbo Ativo & $\begin{array}{l}\text { Martins } \\
\text { (2004) }\end{array}$ & Descendente \\
\hline 417 & 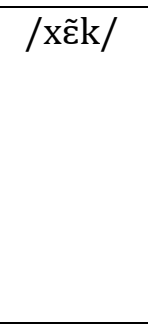 & xẽk & $\begin{array}{c}\text { Estar } \\
\text { quebrado } \\
\text { de um lado } \\
\text { (casa que } \\
\text { só está } \\
\text { coberta de } \\
\text { um lado) }\end{array}$ & $\begin{array}{l}\text { Verbo estativo } \\
\text { descritivo } \\
\text { atributivo }\end{array}$ & $\begin{array}{c}\text { Martins } \\
(2004)\end{array}$ & Atonal \\
\hline 418 & 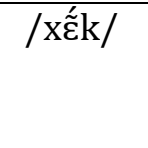 & xẽek & $\begin{array}{l}\text { Cortar no } \\
\text { meio (ex. } \\
\text { beiju) }\end{array}$ & Verbo Ativo & $\begin{array}{l}\text { Martins } \\
\text { (2004) }\end{array}$ & Descendente \\
\hline 419 & /Sap/ & sap & $\begin{array}{l}\text { Estar } \\
\text { rachado }\end{array}$ & $\begin{array}{c}\text { Verbo estativo } \\
\text { descritivo } \\
\text { atributivo } \\
\end{array}$ & $\begin{array}{l}\text { Martins } \\
\text { (2004) }\end{array}$ & Atonal \\
\hline 420 & /Jáp/ & saap & $\begin{array}{l}\text { Rachar e } \\
\text { canal entre } \\
\text { rios }\end{array}$ & Verbo Ativo & $\begin{array}{l}\text { Martins } \\
(2004)\end{array}$ & Descendente \\
\hline 421 & $/ \mathrm{mrm} /$ & mâm & $\begin{array}{l}\text { Ser } \\
\text { redondo e } \\
\text { pequeno }\end{array}$ & $\begin{array}{l}\text { Verbo estativo } \\
\text { descritivo } \\
\text { atributivo }\end{array}$ & $\begin{array}{c}\text { Martins } \\
(2004)\end{array}$ & Atonal \\
\hline 422 & /mr̀m/ & mâam & $\begin{array}{l}\text { Fazer } \\
\text { bolhas }\end{array}$ & Verbo Ativo & $\begin{array}{c}\text { Martins } \\
(2004)\end{array}$ & Descendente \\
\hline 423 & /lãc/ & lõç & $\begin{array}{c}\text { Estar } \\
\text { enrolado, } \\
\text { girar } \\
\end{array}$ & $\begin{array}{c}\text { Verbo estativo } \\
\text { descritivo } \\
\text { atributivo } \\
\end{array}$ & $\begin{array}{l}\text { Martins } \\
\text { (2004) }\end{array}$ & Atonal \\
\hline 424 & /lốc/ & lõoç & $\begin{array}{l}\text { Entortar } \\
\text { dando } \\
\text { voltas, } \\
\text { girar }\end{array}$ & Verbo Ativo & $\begin{array}{l}\text { Martins } \\
\text { (2004) }\end{array}$ & Descendente \\
\hline 425 & /tũm? $/$ & tũm' & $\begin{array}{l}\text { Ser reto e } \\
\text { cilíndrico }\end{array}$ & Verbo estativo & $\begin{array}{l}\text { Martins } \\
(2004)\end{array}$ & Atonal \\
\hline 426 & /tứm? $/$ & tน̃um' & $\begin{array}{c}\text { Tornar reto } \\
\text { e cilíndrico, } \\
\text { costurar } \\
\text { (estativo } \\
\text { transitivad } \\
\text { o) }\end{array}$ & $\begin{array}{c}\text { Verbo } \\
\text { transitivizado }\end{array}$ & $\begin{array}{l}\text { Martins } \\
\text { (2004) }\end{array}$ & Descendente \\
\hline 427 & /com/ & com & Banhar & $\begin{array}{l}\text { Verbo Ativo } \\
\text { Intransitivo }\end{array}$ & $\begin{array}{l}\text { Martins } \\
(2004)\end{array}$ & Atonal \\
\hline
\end{tabular}




\begin{tabular}{|c|c|c|c|c|c|c|}
\hline 428 & /cép/ & cêep & Arrebentar & $\begin{array}{l}\text { Verbo Ativo } \\
\text { Transitivo }\end{array}$ & $\begin{array}{l}\text { Martins } \\
(2004)\end{array}$ & Descendente \\
\hline 429 & /j?ét/ & j'êet & $\begin{array}{l}\text { Deixar no } \\
\text { chão }\end{array}$ & $\begin{array}{c}\text { Verbo Ativo } \\
\text { Transitivo }\end{array}$ & $\begin{array}{l}\text { Martins } \\
(2004)\end{array}$ & Descendente \\
\hline 430 & $/ / \varepsilon n^{2} /$ & 'em’ & $\begin{array}{c}\text { Ser sem } \\
\text { equilíbrio }\end{array}$ & Verbo Estativo & $\begin{array}{l}\text { Martins } \\
(2004)\end{array}$ & Atonal \\
\hline 431 & /m?ũt/ & $\mathrm{m}^{\prime} \tilde{\mathrm{t} t}$ & $\begin{array}{c}\text { Ser ou } \\
\text { estar } \\
\text { redondo }\end{array}$ & Verbo Estativo & $\begin{array}{l}\text { Martins } \\
(2004)\end{array}$ & Atonal \\
\hline 432 & /woj/ & woy & Sovinar & $\begin{array}{l}\text { Verbo Ativo } \\
\text { Intransitivo }\end{array}$ & $\begin{array}{l}\text { Martins } \\
(2004)\end{array}$ & Atonal \\
\hline 433 & /wrg/ & wâg & $\begin{array}{l}\text { Balançar } \\
\text { do galho }\end{array}$ & $\begin{array}{l}\text { Verbo Ativo } \\
\text { Intransitivo }\end{array}$ & $\begin{array}{l}\text { Martins } \\
(2004)\end{array}$ & Atonal \\
\hline 434 & /kil/ & ki' & $\begin{array}{c}\text { Estar } \\
\text { rachado } \\
\text { (para pés e } \\
\text { mãos) }\end{array}$ & Verbo Estativo & $\begin{array}{l}\text { Martins } \\
(2004)\end{array}$ & Atonal \\
\hline 435 & /do?/ & do' & $\begin{array}{c}\text { Estar } \\
\text { queimado }\end{array}$ & Verbo Estativo & $\begin{array}{l}\text { Martins } \\
(2004) \\
\end{array}$ & Atonal \\
\hline 436 & $/$ /द̀n? & 'een' & Virar & $\begin{array}{c}\text { Verbo Ativo } \\
\text { Transitivo } \\
\end{array}$ & $\begin{array}{l}\text { Martins } \\
(2004)\end{array}$ & Descendente \\
\hline 437 & $/ \mathrm{m}^{?} \mathrm{u} u t /$ & $\mathrm{m}^{\prime} \tilde{\mathrm{u} t}$ & Arredondar & $\begin{array}{c}\text { Verbo Ativo } \\
\text { Transitivo }\end{array}$ & $\begin{array}{l}\text { Martins } \\
(2004)\end{array}$ & Atonal \\
\hline 438 & /wój/ & wooy & $\begin{array}{c}\text { Guardar } \\
\text { para o } \\
\text { outro } \\
\end{array}$ & $\begin{array}{l}\text { Verbo Ativo } \\
\text { Transitivo }\end{array}$ & $\begin{array}{l}\text { Martins } \\
(2004)\end{array}$ & Ascendente \\
\hline 439 & /wŕg/ & wâag & $\begin{array}{c}\text { Sacudir a } \\
\text { rede para } \\
\text { acordar o } \\
\text { outro } \\
\end{array}$ & $\begin{array}{c}\text { Verbo Ativo } \\
\text { Transitivo }\end{array}$ & $\begin{array}{l}\text { Martins } \\
(2004)\end{array}$ & Ascendente \\
\hline 440 & /kíl / & $\mathrm{ki}^{\prime}$ & $\begin{array}{c}\text { Abrir couro } \\
\text { de caça }\end{array}$ & $\begin{array}{c}\text { Verbo Ativo } \\
\text { Transitivo } \\
\end{array}$ & $\begin{array}{l}\text { Martins } \\
(2004)\end{array}$ & Ascendente \\
\hline 441 & /dó?/ & doo' & $\begin{array}{l}\text { Acender } \\
\text { fogo }\end{array}$ & $\begin{array}{c}\text { Verbo Ativo } \\
\text { Transitivo } \\
\end{array}$ & $\begin{array}{l}\text { Martins } \\
(2004)\end{array}$ & Ascendente \\
\hline 442 & /lì̀b/ & lâab & Fazer girar & $\begin{array}{c}\text { Verbo Ativo } \\
\text { Transitivo } \\
\end{array}$ & $\begin{array}{l}\text { Martins } \\
(2004) \\
\end{array}$ & Descendente \\
\hline 443 & /tr̀̀w/ & tâaw & Estar Bravo & Verbo Estativo & $\begin{array}{c}\text { Martins } \\
(2004) \\
\end{array}$ & Ascendente \\
\hline 444 & /tuk/ & tuk & Querer & Verbo Ativo & $\begin{array}{l}\text { Martins } \\
(2004)\end{array}$ & Atonal \\
\hline 445 & /wiil/ & $w^{\prime} i^{\prime}$ & $\begin{array}{l}\text { Ser alto e } \\
\text { fino }\end{array}$ & Verbo Estativo & $\begin{array}{l}\text { Martins } \\
(2004)\end{array}$ & Atonal \\
\hline 446 & $/ \mathrm{n} \tilde{\check{\varepsilon}} \mathrm{d} /$ & nẽed & Vir & Verbo Ativo & $\begin{array}{l}\text { Martins } \\
(2004)\end{array}$ & Descendente \\
\hline 447 & /nª̃m/ & n'ãm & $\begin{array}{c}\text { Ser } \\
\text { perigoso }\end{array}$ & Verbo Estativo & $\begin{array}{l}\text { Martins } \\
(2004)\end{array}$ & Atonal \\
\hline 448 & /kub/ & $\mathrm{kub}$ & $\begin{array}{c}\text { Estar } \\
\text { escuro }\end{array}$ & Verbo Estativo & $\begin{array}{c}\text { Martins } \\
(2004)\end{array}$ & Atonal \\
\hline 449 & $/ j^{\mathrm{i}} \varepsilon \mathrm{w}^{\mathrm{T}} /$ & j'ew' & Espatifar & Verbo Ativo & $\begin{array}{l}\text { Martins } \\
(2004) \\
\end{array}$ & Atonal \\
\hline 450 & / Júk/ & suuk & Jogar & Verbo Ativo & $\begin{array}{l}\text { Martins } \\
(2004)\end{array}$ & Descendente \\
\hline 451 & $/ w \gamma j^{3} /$ & wâj' & Ver & Verbo Ativo & Martins & Atonal \\
\hline
\end{tabular}




\begin{tabular}{|c|c|c|c|c|c|c|}
\hline & & & & & $(2004)$ & \\
\hline 452 & /hr̀̀g/ & hâag & Espiar & Verbo Ativo & $\begin{array}{l}\text { Martins } \\
(2004)\end{array}$ & Descendente \\
\hline 453 & /wช́?/ & wâa' & Escutar & Verbo Ativo & $\begin{array}{l}\text { Martins } \\
(2004)\end{array}$ & Ascendente \\
\hline 454 & $/ \mathrm{no} /$ & no & $\begin{array}{c}\text { Ser } \\
\text { vermelho }\end{array}$ & Verbo estativo & $\begin{array}{l}\text { Martins } \\
(2004) \\
\end{array}$ & Atonal \\
\hline 455 & /jah/ & yar & Levar & $\begin{array}{l}\text { Verbo Ativo } \\
\text { Intransitivo }\end{array}$ & $\begin{array}{l}\text { Martins } \\
(2004)\end{array}$ & Atonal \\
\hline 456 & /hõk/ & rõk & Cortar & $\begin{array}{c}\text { Verbo Ativo } \\
\text { Transitivo }\end{array}$ & $\begin{array}{l}\text { Martins } \\
(2004)\end{array}$ & Atonal \\
\hline 457 & /w?òb/ & w'ôob & $\begin{array}{c}\text { Por em } \\
\text { cima }\end{array}$ & $\begin{array}{l}\text { Verbo Ativo } \\
\text { bitransitivo }\end{array}$ & $\begin{array}{l}\text { Martins } \\
(2004)\end{array}$ & Descendente \\
\hline 458 & /he?/ & rề' & Cavar & $\begin{array}{c}\text { Verbo Ativo } \\
\text { Transitivo } \\
\end{array}$ & $\begin{array}{l}\text { Martins } \\
(2004) \\
\end{array}$ & Atonal \\
\hline 459 & /ló?/ & loo' & $\begin{array}{c}\text { Comprar/V } \\
\text { ender }\end{array}$ & Verbo Ativo & $\begin{array}{c}\text { Martins } \\
(2004) \\
\end{array}$ & Descendente \\
\hline 460 & /xa/ & xa & $\begin{array}{c}\text { Estar } \\
\text { agachado }\end{array}$ & Verbo Estativo & $\begin{array}{c}\text { Martins } \\
(2004)\end{array}$ & Atonal \\
\hline 461 & $/ \mathrm{d} \varepsilon ? /$ & $\mathrm{de}^{\prime}$ & Esperar & Verbo Ativo & $\begin{array}{l}\text { Martins } \\
(2004)\end{array}$ & Atonal \\
\hline 462 & /jum/ & jum & Estar vivo & Verbo Estativo & $\begin{array}{l}\text { Martins } \\
(2004) \\
\end{array}$ & Atonal \\
\hline 463 & /woc/ & woç & Arrancar & Verbo Estativo & $\begin{array}{l}\text { Martins } \\
(2004)\end{array}$ & Atonal \\
\hline 464 & /wàj/ & waay & Mandar & Verbo Estativo & $\begin{array}{c}\text { Martins } \\
(2004) \\
\end{array}$ & Descendente \\
\hline 465 & /wan/ & wan & $\begin{array}{l}\text { Mandar } \\
\text { embora }\end{array}$ & & $\begin{array}{l}\text { Martins } \\
(2004)\end{array}$ & Atonal \\
\hline 466 & /j’̀t/ & jooj & $\begin{array}{l}\text { Tirar o } \\
\text { couro }\end{array}$ & Verbo Ativo & $\begin{array}{l}\text { Martins } \\
(2004) \\
\end{array}$ & Descendente \\
\hline 467 & /Jã?ã/ & sã'ã & $\begin{array}{c}\text { Pôr à } \\
\text { prova, } \\
\text { experiment } \\
\text { ar } \\
\end{array}$ & Verbo Ativo & $\begin{array}{l}\text { Martins } \\
(2004)\end{array}$ & Atonal \\
\hline 468 & $/ \mathrm{xJ} /$ & xo & $\begin{array}{c}\text { Estar } \\
\text { Inchado }\end{array}$ & Verbo Estativo & $\begin{array}{l}\text { Martins } \\
(2004) \\
\end{array}$ & Atonal \\
\hline 469 & /cúk/ & cutk & $\begin{array}{c}\text { Coçar, } \\
\text { comichar }\end{array}$ & Verbo Ativo & $\begin{array}{l}\text { Martins } \\
(2004)\end{array}$ & Descendente \\
\hline 470 & /hẼd-cuk/ & rẽd-çuk & $\begin{array}{l}\text { Ficar com } \\
\text { coceira }\end{array}$ & $\begin{array}{l}\text { Verbo de } \\
\text { processo }\end{array}$ & $\begin{array}{l}\text { Martins } \\
(2004) \\
\end{array}$ & Atonal \\
\hline 471 & hẽd- jù? & rẽd-yuu' & $\begin{array}{l}\text { Ficar com } \\
\text { febre }\end{array}$ & $\begin{array}{l}\text { Verbo de } \\
\text { processo }\end{array}$ & $\begin{array}{l}\text { Martins } \\
(2004) \\
\end{array}$ & Descendente \\
\hline 472 & /hed- jumẽh/ & rẽd-yumẽr & Adoecer & $\begin{array}{l}\text { Verbo de } \\
\text { processo }\end{array}$ & $\begin{array}{l}\text { Martins } \\
(2004)\end{array}$ & Atonal \\
\hline 473 & /bá?/ & baa' & Estar fria & Verbo estativo & $\begin{array}{l}\text { Martins } \\
(2004)\end{array}$ & Descendente \\
\hline 474 & /hẼd- bá?/ & rẽd-baa' & $\begin{array}{l}\text { Ficar com } \\
\text { frio }\end{array}$ & $\begin{array}{l}\text { Verbo de } \\
\text { processo }\end{array}$ & $\begin{array}{l}\text { Martins } \\
(2004)\end{array}$ & Descendente \\
\hline 475 & 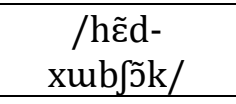 & rẽd-xubsõk & $\begin{array}{c}\text { Tornar-se } \\
\text { triste }\end{array}$ & $\begin{array}{l}\text { Verbo de } \\
\text { processo }\end{array}$ & $\begin{array}{l}\text { Martins } \\
(2004) \\
\end{array}$ & Atonal \\
\hline 476 & /woh/ & wor & Enfeitar & Verbo Ativo & $\begin{array}{l}\text { Martins } \\
(2004) \\
\end{array}$ & Atonal \\
\hline
\end{tabular}




\begin{tabular}{|c|c|c|c|c|c|c|}
\hline 477 & /wĩ̃ñ & w'ĩnh' & Mexer & Verbo ativo & $\begin{array}{l}\text { Martins } \\
(2004)\end{array}$ & Atonal \\
\hline 478 & /ka?/ & ka' & $\begin{array}{c}\text { Estar } \\
\text { pendurado }\end{array}$ & Verbo Estativo & $\begin{array}{l}\text { Martins } \\
(2004)\end{array}$ & Atonal \\
\hline 479 & /xub- jùm/ & xub-yшum & $\begin{array}{l}\text { Restabelec } \\
\text { er a saúde }\end{array}$ & $\begin{array}{l}\text { Verbo de } \\
\text { processo }\end{array}$ & $\begin{array}{l}\text { Martins } \\
(2004)\end{array}$ & Descendente \\
\hline 480 & /xub- tr̀ww/ & xub-tâaw & Ficar brava & $\begin{array}{l}\text { Verbo de } \\
\text { processo }\end{array}$ & $\begin{array}{l}\text { Martins } \\
(2004)\end{array}$ & Descendente \\
\hline 481 & /hedbu/ & redbu & $\begin{array}{l}\text { Ficar com } \\
\text { vergonha }\end{array}$ & $\begin{array}{l}\text { Verbo de } \\
\text { processo }\end{array}$ & $\begin{array}{l}\text { Martins } \\
(2004)\end{array}$ & Atonal \\
\hline 482 & /hedfi/ & redsi & $\begin{array}{l}\text { Ficar com } \\
\text { frio }\end{array}$ & $\begin{array}{l}\text { Verbo de } \\
\text { processo }\end{array}$ & $\begin{array}{l}\text { Martins } \\
(2004)\end{array}$ & Atonal \\
\hline 483 & /hedbax/ & redbax & Ficar suado & $\begin{array}{l}\text { Verbo de } \\
\text { processo }\end{array}$ & $\begin{array}{l}\text { Martins } \\
(2004)\end{array}$ & Atonal \\
\hline 484 & /xubõk/ & xubõk & Ficar triste & $\begin{array}{l}\text { Verbo de } \\
\text { processo }\end{array}$ & $\begin{array}{l}\text { Martins } \\
(2004)\end{array}$ & Atonal \\
\hline 485 & /jẽ̀w/ & yẽew & Estar bom & Verbo Estativo & $\begin{array}{l}\text { Martins } \\
(2004)\end{array}$ & Descendente \\
\hline 486 & /pòg/ & pôog & $\begin{array}{l}\text { Ser muito } \\
\text { grande }\end{array}$ & Verbo estativo & $\begin{array}{l}\text { Martins } \\
(2004)\end{array}$ & Descendente \\
\hline 487 & /ك’́p/ & soop & $\begin{array}{l}\text { Ir ficar } \\
\text { mais alto }\end{array}$ & $\begin{array}{l}\text { Verbo de } \\
\text { processo }\end{array}$ & $\begin{array}{l}\text { Martins } \\
(2004)\end{array}$ & Descendente \\
\hline 488 & /Rrg/ & ‘̂̀g & Beber & Verbo Ativo & $\begin{array}{l}\text { Martins } \\
(2004)\end{array}$ & Atonal \\
\hline 489 & /kŕk/ & kâak & Amarrar & Verbo Ativo & $\begin{array}{l}\text { Martins } \\
(2004)\end{array}$ & Descendente \\
\hline 490 & /drw xŕk/ & dâw xâak & $\begin{array}{c}\text { Puxar } \\
\text { (genérico) }\end{array}$ & $\begin{array}{l}\text { Verbo de } \\
\text { movimento }\end{array}$ & $\begin{array}{l}\text { Martins } \\
(2004)\end{array}$ & Descendente \\
\hline 491 & /drw kig/ & dâw kig & $\begin{array}{c}\text { Puxar para } \\
\text { separar } \\
\text { briga } \\
\text { (causa) }\end{array}$ & $\begin{array}{c}\text { Verbo de } \\
\text { movimento }\end{array}$ & $\begin{array}{l}\text { Martins } \\
(2004)\end{array}$ & Atonal \\
\hline 492 & /kig/ & kig & $\begin{array}{c}\text { Puxar para } \\
\text { separar } \\
\text { briga } \\
\text { (causa) }\end{array}$ & $\begin{array}{l}\text { Verbo de } \\
\text { movimento }\end{array}$ & $\begin{array}{l}\text { Martins } \\
(2004)\end{array}$ & Atonal \\
\hline 493 & /drw mũw? $/$ & dâw mũw' & $\begin{array}{l}\text { Puxar o } \\
\text { peixe } \\
\text { fisgado } \\
\text { (tema) }\end{array}$ & $\begin{array}{l}\text { Verbo de } \\
\text { movimento }\end{array}$ & $\begin{array}{l}\text { Martins } \\
(2004)\end{array}$ & Atonal \\
\hline 494 & /drw wid/ & dâw wid & $\begin{array}{c}\text { Puxar pelo } \\
\text { braço } \\
\text { (maneira) }\end{array}$ & $\begin{array}{l}\text { Verbo de } \\
\text { movimento }\end{array}$ & $\begin{array}{l}\text { Martins } \\
(2004)\end{array}$ & Atonal \\
\hline 495 & /drw jóc/ & dâw yooç & $\begin{array}{l}\text { Puxar da } \\
\text { mão } \\
\text { (fonte) }\end{array}$ & $\begin{array}{c}\text { Verbo de } \\
\text { movimento }\end{array}$ & $\begin{array}{c}\text { Martins } \\
(2004)\end{array}$ & Descendente \\
\hline 496 & /drw crk/ & dâw câk & $\begin{array}{c}\text { Pular } \\
\text { (genérico) }\end{array}$ & $\begin{array}{c}\text { Verbo de } \\
\text { movimento }\end{array}$ & $\begin{array}{l}\text { Martins } \\
(2004)\end{array}$ & Atonal \\
\hline 497 & /crk/ & çâk & Pular & Verbo Ativo & Martins & Atonal \\
\hline
\end{tabular}




\begin{tabular}{|c|c|c|c|c|c|c|}
\hline & & & & intransitivo & (2004) & \\
\hline 498 & /wŕp/ & wâap & $\begin{array}{l}\text { Pular na } \\
\text { água }\end{array}$ & $\begin{array}{l}\text { Verbo Ativo } \\
\text { Intransitivo }\end{array}$ & $\begin{array}{l}\text { Martins } \\
\text { (2004) }\end{array}$ & Descendente \\
\hline 499 & /hấp ?'́w? / & rãap 'âaw' & $\begin{array}{c}\text { Pular só } \\
\text { para peixe } \\
\text { (agente) }\end{array}$ & $\begin{array}{c}\text { Verbo de } \\
\text { movimento }\end{array}$ & $\begin{array}{c}\text { Martins } \\
(2004)\end{array}$ & Descendente \\
\hline 500 & /drw wrp/ & dâw wâp & $\begin{array}{c}\text { Pular na } \\
\text { água (alvo) }\end{array}$ & $\begin{array}{c}\text { Verbo de } \\
\text { movimento }\end{array}$ & $\begin{array}{l}\text { Martins } \\
\text { (2004) }\end{array}$ & Atonal \\
\hline 501 & /drw wŕp/ & dâw wâap & $\begin{array}{l}\text { Pular no rio } \\
\text { (alvo) }\end{array}$ & $\begin{array}{c}\text { Verbo de } \\
\text { movimento }\end{array}$ & $\begin{array}{c}\text { Martins } \\
(2004)\end{array}$ & Descendente \\
\hline 502 & /drw nrx/ & dâw nâx & $\begin{array}{l}\text { Pular em } \\
\text { cima de } \\
\text { (alvo) }\end{array}$ & $\begin{array}{c}\text { Verbo de } \\
\text { movimento }\end{array}$ & $\begin{array}{c}\text { Martins } \\
(2004)\end{array}$ & Atonal \\
\hline 503 & /be won/ & be wôn & $\begin{array}{c}\text { Pau prestes } \\
\text { a cair }\end{array}$ & $\begin{array}{c}\text { Verbo de } \\
\text { movimento }\end{array}$ & $\begin{array}{c}\text { Martins } \\
(2004)\end{array}$ & Atonal \\
\hline 504 & /nช́x dof/ & nâax doj & $\begin{array}{l}\text { Cair água } \\
\text { (alvo) }\end{array}$ & $\begin{array}{l}\text { Verbo de } \\
\text { movimento }\end{array}$ & $\begin{array}{c}\text { Martins } \\
\text { (2004) }\end{array}$ & Descendente \\
\hline 505 & /dof jee?/ & doj y'ề' & $\begin{array}{c}\text { Cair água } \\
\text { sem parar } \\
\text { (aspectuali } \\
\text { dade) }\end{array}$ & $\begin{array}{l}\text { Verbo de } \\
\text { movimento }\end{array}$ & $\begin{array}{l}\text { Martins } \\
\text { (2004) }\end{array}$ & Atonal \\
\hline 506 & /xutu/ & xutu & Descer, cair & Verbo Ativo & $\begin{array}{l}\text { Martins } \\
(2004)\end{array}$ & Atonal \\
\hline 507 & /kutu krtu/ & kutu kâtu & $\begin{array}{l}\text { Descer da } \\
\text { rede }\end{array}$ & Verbo Ativo & $\begin{array}{l}\text { Martins } \\
(2004)\end{array}$ & Atonal \\
\hline 508 & $/ \mathrm{nrx} /$ & nâx & Cair & Verbo Ativo & $\begin{array}{l}\text { Martins } \\
(2004)\end{array}$ & Atonal \\
\hline 509 & /wrp/ & wâp & $\begin{array}{c}\text { Cair na } \\
\text { água }\end{array}$ & Verbo Ativo & $\begin{array}{l}\text { Martins } \\
(2004)\end{array}$ & Atonal \\
\hline 510 & /ñ̃k/ & nõk & Cair & Verbo Ativo & $\begin{array}{l}\text { Martins } \\
(2004) \\
\end{array}$ & Atonal \\
\hline 511 & /xu/ & $\mathrm{xH}$ & Cair & $\begin{array}{l}\text { Verbos de } \\
\text { processo }\end{array}$ & $\begin{array}{l}\text { Martins } \\
(2004)\end{array}$ & Atonal \\
\hline 512 & /drw ñ̃x/ & dâw nõx & $\begin{array}{l}\text { Cair longe } \\
\text { (alvo) }\end{array}$ & $\begin{array}{l}\text { Verbo de } \\
\text { movimento }\end{array}$ & $\begin{array}{l}\text { Martins } \\
(2004)\end{array}$ & Atonal \\
\hline 513 & /liax/ & l'ax & Cair & $\begin{array}{c}\text { Verbo } \\
\text { intransitivo }\end{array}$ & $\begin{array}{l}\text { Martins } \\
(2004) \\
\end{array}$ & Atonal \\
\hline 514 & $/ \int \varepsilon n /$ & senh & $\begin{array}{c}\text { Tropeçar e } \\
\text { cair }\end{array}$ & $\begin{array}{c}\text { Verbo } \\
\text { intransitivo }\end{array}$ & $\begin{array}{l}\text { Martins } \\
(2004)\end{array}$ & Atonal \\
\hline 515 & /hod/ & rod & $\begin{array}{l}\text { Sair, nascer } \\
\text { (genérico) }\end{array}$ & $\begin{array}{c}\text { Verbo de } \\
\text { movimento }\end{array}$ & $\begin{array}{c}\text { Martins } \\
\text { (2004) }\end{array}$ & Atonal \\
\hline 516 & /j? xכ?/ & j'o xo' & $\begin{array}{c}\text { Sair só para } \\
\text { caba } \\
\text { (agente) }\end{array}$ & $\begin{array}{c}\text { Verbo de } \\
\text { movimento }\end{array}$ & $\begin{array}{c}\text { Martins } \\
(2004)\end{array}$ & Atonal \\
\hline 517 & /bog/ & bog & Sair a pele & Verbo de & Martins & Atonal \\
\hline
\end{tabular}




\begin{tabular}{|c|c|c|c|c|c|c|}
\hline & & & (tema) & movimento & $(2004)$ & \\
\hline 518 & /כ̃̀̀c/ & õoç & $\begin{array}{l}\text { Sair para } \\
\text { uma } \\
\text { clareira } \\
\text { (trajetória, } \\
\text { direção) }\end{array}$ & $\begin{array}{l}\text { Verbo de } \\
\text { movimento }\end{array}$ & $\begin{array}{l}\text { Martins } \\
\text { (2004) }\end{array}$ & Descendente \\
\hline 519 & /xet drh/ & xer dâr & $\begin{array}{l}\text { Movimenta } \\
\text { r-se rápido } \\
\text { (maneira) }\end{array}$ & $\begin{array}{l}\text { Verbo de } \\
\text { movimento }\end{array}$ & $\begin{array}{c}\text { Martins } \\
\text { (2004) }\end{array}$ & Atonal \\
\hline 520 & /nũwux/ & nũwtx & $\begin{array}{l}\text { Movimenta } \\
r \\
\text { velozmente } \\
\text { (maneira) }\end{array}$ & $\begin{array}{l}\text { Verbo de } \\
\text { movimento }\end{array}$ & $\begin{array}{c}\text { Martins } \\
(2004)\end{array}$ & Atonal \\
\hline 521 & /lib/ & lib & $\begin{array}{l}\text { Fazer } \\
\text { movimento } \\
\text { rápido e } \\
\text { circular } \\
\text { (maneira) }\end{array}$ & $\begin{array}{l}\text { Verbo de } \\
\text { movimento }\end{array}$ & $\begin{array}{c}\text { Martins } \\
\text { (2004) }\end{array}$ & Atonal \\
\hline 522 & /lrb/ & lâb & $\begin{array}{c}\text { Rodar, } \\
\text { girar (ex. } \\
\text { bola) } \\
\text { (genérico) }\end{array}$ & $\begin{array}{l}\text { Verbo de } \\
\text { movimento }\end{array}$ & $\begin{array}{c}\text { Martins } \\
\text { (2004) }\end{array}$ & Atonal \\
\hline 523 & /hep/ & rep & $\begin{array}{c}\text { Rodar com } \\
\text { o vento } \\
\text { (agente) }\end{array}$ & $\begin{array}{c}\text { Verbo de } \\
\text { movimento }\end{array}$ & $\begin{array}{c}\text { Martins } \\
\text { (2004) }\end{array}$ & Atonal \\
\hline 524 & /prd/ & pâd & $\begin{array}{c}\text { Rodar, } \\
\text { dando } \\
\text { cambalhota } \\
\text { s } \\
\text { (maneira) }\end{array}$ & $\begin{array}{l}\text { Verbo de } \\
\text { movimento }\end{array}$ & $\begin{array}{c}\text { Martins } \\
\text { (2004) }\end{array}$ & Atonal \\
\hline 525 & /lốc/ & lõoç & $\begin{array}{c}\text { Rodar, } \\
\text { circulando } \\
\text { um ponto } \\
\text { (trajetória) }\end{array}$ & $\begin{array}{l}\text { Verbo de } \\
\text { movimento }\end{array}$ & $\begin{array}{c}\text { Martins } \\
(2004)\end{array}$ & Descendente \\
\hline 526 & /lóc/ & lôoc & $\begin{array}{l}\text { Brincar de } \\
\text { roda } \\
\text { (circunstân } \\
\text { cia) }\end{array}$ & $\begin{array}{c}\text { Verbo de } \\
\text { movimento }\end{array}$ & $\begin{array}{c}\text { Martins } \\
\text { (2004) }\end{array}$ & Descendente \\
\hline 527 & /wr̀̀g/ & wâag & $\begin{array}{c}\text { Sacudir a } \\
\text { rede para } \\
\text { acordar o } \\
\text { outro } \\
\text { (origem/ca } \\
\text { usa) }\end{array}$ & $\begin{array}{l}\text { Verbo de } \\
\text { movimento }\end{array}$ & $\begin{array}{c}\text { Martins } \\
\text { (2004) }\end{array}$ & Ascendente \\
\hline 528 & /Rû̀w/ & ‘̃uw & $\begin{array}{c}\text { Sacudir a } \\
\text { cabeça } \\
\text { quando }\end{array}$ & $\begin{array}{l}\text { Verbo de } \\
\text { movimento }\end{array}$ & $\begin{array}{c}\text { Martins } \\
(2004)\end{array}$ & Descendente \\
\hline
\end{tabular}




\begin{tabular}{|c|c|c|c|c|c|c|}
\hline & & & $\begin{array}{c}\text { está bravo } \\
\text { (origem/ca } \\
\text { usa) }\end{array}$ & & & \\
\hline 529 & /jũw/ & 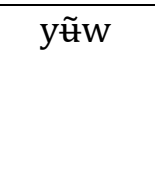 & $\begin{array}{l}\text { Sacudir } \\
\text { para pôr } \\
\text { para fora } \\
\text { (causa) }\end{array}$ & $\begin{array}{l}\text { Verbo de } \\
\text { movimento }\end{array}$ & $\begin{array}{l}\text { Martins } \\
(2004)\end{array}$ & Atonal \\
\hline 530 & /buj/ & buy & $\begin{array}{c}\text { Acudir } \\
\text { galho para } \\
\text { derrubar } \\
\text { fruta } \\
\text { (origem/ca } \\
\text { usa) }\end{array}$ & $\begin{array}{l}\text { Verbo de } \\
\text { movimento }\end{array}$ & $\begin{array}{l}\text { Martins } \\
(2004)\end{array}$ & Atonal \\
\hline 531 & /pãs/ & pãs & $\begin{array}{c}\text { Sacudir a } \\
\text { cabeça } \\
\text { (tirar algo } \\
\text { do ouvido) } \\
\text { (origem/ca } \\
\text { usa) }\end{array}$ & $\begin{array}{c}\text { Verbo de } \\
\text { movimento }\end{array}$ & $\begin{array}{c}\text { Martins } \\
(2004)\end{array}$ & Atonal \\
\hline 532 & /Ják/ & saak & $\begin{array}{c}\text { Subir; } \\
\text { crescer } \\
\text { (genérico) }\end{array}$ & $\begin{array}{l}\text { Verbo de } \\
\text { movimento }\end{array}$ & $\begin{array}{l}\text { Martins } \\
(2004)\end{array}$ & Atonal \\
\hline 533 & $/ \mathrm{p} \varepsilon /$ & pe & $\begin{array}{l}\text { Subir rio } \\
\text { acima } \\
\text { (trajetória, } \\
\text { direção) }\end{array}$ & $\begin{array}{c}\text { Verbo de } \\
\text { movimento }\end{array}$ & $\begin{array}{c}\text { Martins } \\
(2004)\end{array}$ & Atonal \\
\hline 534 & /hõ̀n/ & rõon & $\begin{array}{l}\text { Subir em } \\
\text { árvore para } \\
\text { se } \\
\text { direcionar } \\
\text { (instrumen } \\
\text { to) }\end{array}$ & $\begin{array}{l}\text { Verbo de } \\
\text { movimento }\end{array}$ & $\begin{array}{l}\text { Martins } \\
\text { (2004) }\end{array}$ & Descendente \\
\hline 535 & / /śp/ & soop & $\begin{array}{c}\text { Subir; } \\
\text { aumentar } \\
\text { de volume } \\
\text { (meta) }\end{array}$ & $\begin{array}{l}\text { Verbo de } \\
\text { movimento }\end{array}$ & $\begin{array}{l}\text { Martins } \\
(2004)\end{array}$ & Ascendente \\
\hline 536 & /jo?/ & yô' & $\begin{array}{c}\text { Carregar na } \\
\text { mão, } \\
\text { suspenden } \\
\text { do } \\
\text { (maneira) }\end{array}$ & $\begin{array}{l}\text { Verbo de } \\
\text { movimento }\end{array}$ & $\begin{array}{l}\text { Martins } \\
(2004)\end{array}$ & Atonal \\
\hline 537 & /كé dó?/ & sêe dôo' & $\begin{array}{c}\text { Carregar } \\
\text { paneiro } \\
\text { (tema) }\end{array}$ & $\begin{array}{l}\text { Verbo de } \\
\text { movimento }\end{array}$ & $\begin{array}{l}\text { Martins } \\
(2004)\end{array}$ & Ascendente \\
\hline 538 & $/$ Set/ & sêt & $\begin{array}{l}\text { Carregar } \\
\text { apoiado na } \\
\text { cabeça } \\
\text { (maneira) }\end{array}$ & $\begin{array}{l}\text { Verbo de } \\
\text { movimento }\end{array}$ & $\begin{array}{l}\text { Martins } \\
(2004)\end{array}$ & Atonal \\
\hline 539 & /tòw/ & toow & $\begin{array}{l}\text { Carregar } \\
\text { nos braços } \\
\text { (maneira) }\end{array}$ & $\begin{array}{l}\text { Verbo de } \\
\text { movimento }\end{array}$ & $\begin{array}{l}\text { Martins } \\
(2004)\end{array}$ & Descendente \\
\hline
\end{tabular}




\begin{tabular}{|c|c|c|c|c|c|c|}
\hline 540 & /ton/ & tôn & $\begin{array}{c}\text { Carregar na } \\
\text { mão } \\
\text { (maneira) }\end{array}$ & $\begin{array}{l}\text { Verbo de } \\
\text { movimento }\end{array}$ & $\begin{array}{l}\text { Martins } \\
(2004)\end{array}$ & Atonal \\
\hline 541 & /tòj/ & tôoy & $\begin{array}{l}\text { Carregar } \\
\text { no ombro } \\
\text { (ex. pau) } \\
\text { (maneira) }\end{array}$ & $\begin{array}{l}\text { Verbo de } \\
\text { movimento }\end{array}$ & $\begin{array}{c}\text { Martins } \\
(2004)\end{array}$ & Descendente \\
\hline 542 & /tóji'/ & tôoy' & $\begin{array}{c}\text { Carregar } \\
\text { no pescoço } \\
\text { (ex. } \\
\text { criança) } \\
\text { (maneira) }\end{array}$ & $\begin{array}{l}\text { Verbo de } \\
\text { movimento }\end{array}$ & $\begin{array}{l}\text { Martins } \\
(2004)\end{array}$ & Ascendente \\
\hline 543 & $/ \mathrm{lu} /$ & 'u & $\begin{array}{l}\text { Carregar } \\
\text { nos braços } \\
\text { (maneira) }\end{array}$ & $\begin{array}{l}\text { Verbo de } \\
\text { movimento }\end{array}$ & $\begin{array}{l}\text { Martins } \\
(2004)\end{array}$ & Atonal \\
\hline 544 & $/ \mathrm{Se} /$ & sê & $\begin{array}{l}\text { Carregar } \\
\text { nos quadris } \\
\text { (maneira) }\end{array}$ & $\begin{array}{l}\text { Verbo de } \\
\text { movimento }\end{array}$ & $\begin{array}{l}\text { Martins } \\
(2004)\end{array}$ & Atonal \\
\hline 545 & $/ \int \tilde{\varepsilon} /$ & sẽ & $\begin{array}{l}\text { Carregar } \\
\text { palha nas } \\
\text { costas } \\
\text { (tema } / \text { man } \\
\text { eira) } \\
\end{array}$ & $\begin{array}{l}\text { Verbo de } \\
\text { movimento }\end{array}$ & $\begin{array}{c}\text { Martins } \\
(2004)\end{array}$ & Atonal \\
\hline 546 & / Ju?/ & $\mathrm{su}^{\prime}$ & $\begin{array}{l}\text { Carregar } \\
\text { criança nas } \\
\text { costas } \\
\text { (tema } \\
\text { /maneira) }\end{array}$ & $\begin{array}{l}\text { Verbo de } \\
\text { movimento }\end{array}$ & $\begin{array}{c}\text { Martins } \\
(2004)\end{array}$ & Atonal \\
\hline 547 & /hãm/ & rãm & $\begin{array}{c}\text { Ir } \\
\text { (genérico) }\end{array}$ & $\begin{array}{c}\text { Verbo de } \\
\text { movimento }\end{array}$ & $\begin{array}{c}\text { Martins } \\
(2004)\end{array}$ & Atonal \\
\hline 548 & /hầm/ & rãam & $\begin{array}{l}\text { Ir levar } \\
\text { alguma } \\
\text { coisa (tema } \\
\text { /causa) } \\
\end{array}$ & $\begin{array}{c}\text { Verbo de } \\
\text { movimento }\end{array}$ & $\begin{array}{c}\text { Martins } \\
(2004)\end{array}$ & Descendente \\
\hline 549 & /hấ?/ & rãa' & $\begin{array}{l}\text { Ir levar } \\
\text { alguém } \\
\text { (tema } \\
\text { /causa) }\end{array}$ & $\begin{array}{l}\text { Verbo de } \\
\text { movimento }\end{array}$ & $\begin{array}{l}\text { Martins } \\
(2004)\end{array}$ & Ascendente \\
\hline 550 & $/ \mathrm{m} \tilde{́} \mathrm{~m} /$ & mẽem & $\begin{array}{l}\text { Levar } \\
\text { debaixo do } \\
\text { braço }\end{array}$ & $\begin{array}{c}\text { Não } \\
\text { classificado por } \\
\text { Martins } \\
\end{array}$ & $\begin{array}{l}\text { Martins } \\
(2004)\end{array}$ & Ascendente \\
\hline 551 & /wah/ & war & $\begin{array}{c}\text { Ir ou } \\
\text { chegar } \\
\text { antes do } \\
\text { outro } \\
\text { (trajetória } \\
\text { /meta) }\end{array}$ & $\begin{array}{l}\text { Verbo de } \\
\text { movimento }\end{array}$ & $\begin{array}{l}\text { Martins } \\
(2004)\end{array}$ & Atonal \\
\hline 552 & /dòb/ & dôob & $\begin{array}{l}\text { Ir para o } \\
\text { porto } \\
\text { (meta) }\end{array}$ & $\begin{array}{l}\text { Verbo de } \\
\text { movimento }\end{array}$ & $\begin{array}{c}\text { Martins } \\
(2004)\end{array}$ & Descendente \\
\hline 553 & $/ \int \gamma \mathrm{k} /$ & sâk & Ir perto do & Verbo de & Martins & Atonal \\
\hline
\end{tabular}




\begin{tabular}{|c|c|c|c|c|c|c|}
\hline & & & $\begin{array}{c}\text { ponto de } \\
\text { origem } \\
\text { (trajetória) }\end{array}$ & movimento & $(2004)$ & \\
\hline 554 & /wàn/ & waan & $\begin{array}{l}\text { Ir seguindo } \\
\text { o rastro de } \\
\text { animal } \\
\text { (agente } \\
\text { /trajetória) }\end{array}$ & $\begin{array}{l}\text { Verbo de } \\
\text { movimento }\end{array}$ & $\begin{array}{l}\text { Martins } \\
(2004)\end{array}$ & Descendente \\
\hline 555 & /jót/ & yoot & $\begin{array}{l}\text { Ir seguindo } \\
\text { o rastro de } \\
\text { gente } \\
\text { (agente } \\
\text { /trajetória) }\end{array}$ & $\begin{array}{l}\text { Verbo de } \\
\text { movimento }\end{array}$ & $\begin{array}{l}\text { Martins } \\
(2004)\end{array}$ & Ascendente \\
\hline 556 & /dó?/ & dôo' & $\begin{array}{l}\text { Movimenta } \\
\text { r, tirar }\end{array}$ & $\begin{array}{l}\text { Verbo de } \\
\text { movimento }\end{array}$ & $\begin{array}{l}\text { Martins } \\
(2004)\end{array}$ & Ascendente \\
\hline 557 & /w'́? dó?/ & wâa' dôo' & Obedecer & $\begin{array}{c}\text { Verbo de } \\
\text { movimento em } \\
\text { serialização } \\
\text { verbal }\end{array}$ & $\begin{array}{l}\text { Martins } \\
(2004)\end{array}$ & Ascendente \\
\hline 558 & /wช́?/ & wâa' & Ouvir & Verbo Ativo & $\begin{array}{l}\text { Martins } \\
(2004)\end{array}$ & Ascendente \\
\hline 559 & /xu dó?/ & xu dôo' & Descer e ir & $\begin{array}{c}\text { Verbo de } \\
\text { movimento em } \\
\text { serialização } \\
\text { verbal }\end{array}$ & $\begin{array}{l}\text { Martins } \\
(2004)\end{array}$ & Ascendente \\
\hline 560 & /haj? dó?/ & ray' dôo' & $\begin{array}{l}\text { Segurar e } \\
\text { levar }\end{array}$ & $\begin{array}{c}\text { Verbo de } \\
\text { movimento em } \\
\text { serialização } \\
\text { verbal }\end{array}$ & $\begin{array}{l}\text { Martins } \\
(2004)\end{array}$ & Atonal \\
\hline 561 & /haj?/ & ray' & Segurar & Verbo Ativo & $\begin{array}{l}\text { Martins } \\
(2004)\end{array}$ & Atonal \\
\hline 562 & /dó? xrjr/ & dôo’ wâyâ & $\begin{array}{c}\text { Levar } \\
\text { voltando de }\end{array}$ & $\begin{array}{c}\text { Verbo de } \\
\text { movimento }\end{array}$ & $\begin{array}{l}\text { Martins } \\
(2004)\end{array}$ & Atonal \\
\hline 563 & /dó? xrd/ & dôo' xâd & $\begin{array}{l}\text { Levar indo } \\
\text { para um } \\
\text { ponto } \\
\text { específico } \\
\end{array}$ & $\begin{array}{l}\text { Verbo de } \\
\text { movimento }\end{array}$ & $\begin{array}{l}\text { Martins } \\
(2004)\end{array}$ & Atonal \\
\hline 564 & /dó? Jóp/ & dôo' soop & $\begin{array}{l}\text { Levar indo } \\
\text { para um } \\
\text { lugar mais } \\
\text { alto }\end{array}$ & $\begin{array}{l}\text { Verbo de } \\
\text { movimento }\end{array}$ & $\begin{array}{l}\text { Martins } \\
(2004)\end{array}$ & Ascendente \\
\hline 565 & /Ј’́p/ & soop & Subir & Verbo Ativo & $\begin{array}{c}\text { Martins } \\
(2004)\end{array}$ & Ascendente \\
\hline 566 & /dó? dòb/ & dôo' dôob & $\begin{array}{l}\text { Levar indo } \\
\text { para o } \\
\text { porto } \\
\text { (lugar mais } \\
\text { baixo) } \\
\end{array}$ & $\begin{array}{l}\text { Verbo de } \\
\text { movimento }\end{array}$ & $\begin{array}{l}\text { Martins } \\
(2004)\end{array}$ & Descendente \\
\hline 567 & /dòb/ & dôob & $\begin{array}{l}\text { Descer } \\
\text { para o } \\
\text { porto }\end{array}$ & Verbo Ativo & $\begin{array}{c}\text { Martins } \\
(2004)\end{array}$ & Descendente \\
\hline 568 & /mũn/ & mũun & Abraçar & Verbo Ativo & Martins & Descendente \\
\hline
\end{tabular}




\begin{tabular}{|c|c|c|c|c|c|c|}
\hline & & & & & $(2004)$ & \\
\hline 569 & /wŕp/ & wâap & Jogar & Verbo Ativo & $\begin{array}{c}\text { Martins } \\
(2004)\end{array}$ & Ascendente \\
\hline 570 & /hấ?/ & rãa' & Deixar & Verbo Ativo & $\begin{array}{c}\text { Martins } \\
(2004)\end{array}$ & Ascendente \\
\hline 571 & /pow/ & pôw & Rachar & Verbo Ativo & $\begin{array}{l}\text { Martins } \\
(2004)\end{array}$ & Atonal \\
\hline 572 & /wàb/ & waab & $\begin{array}{c}\text { Partir ao } \\
\text { meio }\end{array}$ & Verbo Ativo & $\begin{array}{l}\text { Martins } \\
(2004)\end{array}$ & Descendnete \\
\hline 573 & /haj?/ & ray' & Pegar & Verbo Ativo & $\begin{array}{l}\text { Martins } \\
(2004)\end{array}$ & Atonal \\
\hline 574 & /kũ / & kũ & Espreitar & Verbo Ativo & $\begin{array}{c}\text { Martins } \\
(2004) \\
\end{array}$ & Atonal \\
\hline 575 & $/ \mathrm{j}^{\mathrm{i}} \varepsilon \mathrm{w}^{\mathrm{T}} /$ & j'ew' & Amassar & Verbo Ativo & $\begin{array}{c}\text { Martins } \\
(2004)\end{array}$ & Atonal \\
\hline 576 & $/ \mathrm{bcw}^{2} /$ & bew' & Amassar & Verbo Ativo & $\begin{array}{l}\text { Martins } \\
(2004)\end{array}$ & Atonal \\
\hline 577 & $/ \mathrm{dit}_{\mathrm{f}} /$ & dij & Amassar & $\begin{array}{c}\text { Não } \\
\text { classificado por } \\
\text { Martins } \\
\end{array}$ & $\begin{array}{l}\text { Martins } \\
\text { (2004) }\end{array}$ & Atonal \\
\hline 578 & /kũm/ & kũm & Alargar & Verbo Ativo & $\begin{array}{c}\text { Martins } \\
(2004)\end{array}$ & Atonal \\
\hline 579 & /tés/ & têes & $\begin{array}{l}\text { Cortar com } \\
\text { terçado }\end{array}$ & Verbo estativo & $\begin{array}{l}\text { Martins } \\
(2004)\end{array}$ & Ascendente \\
\hline 580 & /hốk/ & rõok & $\begin{array}{l}\text { Cortar com } \\
\text { terçado }\end{array}$ & Verbo estativo & $\begin{array}{l}\text { Martins } \\
\text { (2004) }\end{array}$ & Ascendente \\
\hline 581 & $/ / \grave{\gamma} \mathrm{j} /$ & ‘̂ay & Chamar & Verbo Ativo & $\begin{array}{l}\text { Martins } \\
(2004)\end{array}$ & Descendente \\
\hline 582 & $\begin{array}{c}\text { /drw wióji } \\
\text { Ṗ̀j dó?/ }\end{array}$ & $\begin{array}{c}\text { dâw w'âay' 'âay } \\
\text { dôo' }\end{array}$ & Responder & Verbos seriais & $\begin{array}{l}\text { Martins } \\
(2004)\end{array}$ & $\begin{array}{l}\text { Construção } \\
\text { com mais de } \\
\text { um tom }\end{array}$ \\
\hline 583 & $\begin{array}{c}\text { /drw w } w^{i} \gamma j^{3} \\
\text { dák/ }\end{array}$ & $\begin{array}{c}\text { dâw w'âay' } \\
\text { daak }\end{array}$ & Denunciar & Verbos seriais & $\begin{array}{c}\text { Martins } \\
(2004)\end{array}$ & $\begin{array}{l}\text { Construção } \\
\text { com mais de } \\
\text { um tom }\end{array}$ \\
\hline 584 & $\begin{array}{l}\text { /drw wŕ? } \\
\text { dó?/ }\end{array}$ & dâw wâa' dôo' & Obedecer & Verbos seriais & $\begin{array}{c}\text { Martins } \\
\text { (2004) }\end{array}$ & $\begin{array}{l}\text { Construção } \\
\text { com mais de } \\
\text { um tom }\end{array}$ \\
\hline 585 & /cob/ & côb & $\begin{array}{c}\text { Estar } \\
\text { amontoadi } \\
\text { nho (coisas } \\
\text { redondas e } \\
\text { pequenas, } \\
\text { chumbo, } \\
\text { açaí) }\end{array}$ & $\begin{array}{l}\text { Verbo de } \\
\text { posição }\end{array}$ & $\begin{array}{l}\text { Martins } \\
\text { (2004) }\end{array}$ & Atonal \\
\hline 586 & /mãm?/ & mãm' & $\begin{array}{c}\text { Estar } \\
\text { grudado } \\
\text { um no } \\
\text { outro ( ex. } \\
\text { fruta filipe) }\end{array}$ & $\begin{array}{l}\text { Verbo de } \\
\text { posição }\end{array}$ & $\begin{array}{l}\text { Martins } \\
(2004)\end{array}$ & Atonal \\
\hline 587 & /bej/ & bêy & $\begin{array}{c}\text { Estar } \\
\text { amontoado } \\
\text { um ao lado } \\
\text { do outro }\end{array}$ & $\begin{array}{l}\text { Verbo de } \\
\text { posição }\end{array}$ & $\begin{array}{l}\text { Martins } \\
\text { (2004) }\end{array}$ & Atonal \\
\hline
\end{tabular}




\begin{tabular}{|c|c|c|c|c|c|c|}
\hline & & & $\begin{array}{l}\text { (ex. cria de } \\
\text { cachorros) }\end{array}$ & & & \\
\hline 588 & / /oj/ & sôy & $\begin{array}{c}\text { Estar } \\
\text { amontoado } \\
\text { um em } \\
\text { cima do } \\
\text { outro }\end{array}$ & $\begin{array}{l}\text { Verbo de } \\
\text { posição }\end{array}$ & $\begin{array}{c}\text { Martins } \\
\text { (2004) }\end{array}$ & Atonal \\
\hline 589 & /prt/ & pât & $\begin{array}{c}\text { Estar caído } \\
\text { na rede }\end{array}$ & $\begin{array}{c}\text { Verbo de } \\
\text { posição }\end{array}$ & $\begin{array}{l}\text { Martins } \\
(2004)\end{array}$ & Atonal \\
\hline 590 & $/ \mathrm{Ja}$ / & sa' & $\begin{array}{c}\text { Estar caído } \\
\text { (específico } \\
\text { para pau) }\end{array}$ & $\begin{array}{l}\text { Verbo de } \\
\text { posição }\end{array}$ & $\begin{array}{c}\text { Martins } \\
\text { (2004) }\end{array}$ & Atonal \\
\hline 591 & /kó?/ & kôo' & $\begin{array}{c}\text { Estar meio } \\
\text { curvado }\end{array}$ & $\begin{array}{l}\text { Verbo de } \\
\text { posição }\end{array}$ & $\begin{array}{c}\text { Martins } \\
\text { (2004) }\end{array}$ & Ascendente \\
\hline 592 & /lo?/ & lo' & $\begin{array}{c}\text { Estar } \\
\text { inclinado } \\
\text { para frente }\end{array}$ & $\begin{array}{l}\text { Verbo de } \\
\text { posição }\end{array}$ & $\begin{array}{c}\text { Martins } \\
\text { (2004) }\end{array}$ & Atonal \\
\hline 593 & /tut/ & tut & $\begin{array}{c}\text { Estar bem } \\
\text { inclinado } \\
\text { para frente } \\
\text { quase } \\
\text { caindo }\end{array}$ & $\begin{array}{l}\text { Verbo de } \\
\text { posição }\end{array}$ & $\begin{array}{c}\text { Martins } \\
\text { (2004) }\end{array}$ & Atonal \\
\hline 594 & /wãw/ & wãw & $\begin{array}{c}\text { Estar } \\
\text { envergado } \\
\text { (específico } \\
\text { para pau) }\end{array}$ & $\begin{array}{c}\text { Verbo de } \\
\text { posição }\end{array}$ & $\begin{array}{c}\text { Martins } \\
(2004)\end{array}$ & Atonal \\
\hline 595 & /len/ & lên & $\begin{array}{c}\text { Estar } \\
\text { envergado } \\
\text { para os } \\
\text { lados }\end{array}$ & $\begin{array}{l}\text { Verbo de } \\
\text { posição }\end{array}$ & $\begin{array}{c}\text { Martins } \\
\text { (2004) }\end{array}$ & Atonal \\
\hline 596 & /pém/ & peem & $\begin{array}{c}\text { Estar } \\
\text { sentado } \\
\text { (genérico) }\end{array}$ & $\begin{array}{l}\text { Verbo de } \\
\text { posição }\end{array}$ & $\begin{array}{c}\text { Martins } \\
(2004)\end{array}$ & Descendente \\
\hline 597 & /xכg/ & xog & $\begin{array}{c}\text { Estar } \\
\text { sentado } \\
\text { para cutia e } \\
\text { paca } \\
\text { (agente) }\end{array}$ & $\begin{array}{c}\text { Verbo de } \\
\text { posição }\end{array}$ & $\begin{array}{c}\text { Martins } \\
(2004)\end{array}$ & Atonal \\
\hline 598 & /nĩc xaj/ & nĩç xanh & $\begin{array}{c}\text { Sentar com } \\
\text { a perna } \\
\text { encolhida } \\
\text { (maneira) }\end{array}$ & $\begin{array}{l}\text { Verbo de } \\
\text { posição }\end{array}$ & $\begin{array}{c}\text { Martins } \\
\text { (2004) }\end{array}$ & Atonal \\
\hline 599 & $/ \int \tilde{w^{2}} \mathrm{xa} /$ & sõw' xa & $\begin{array}{l}\text { Sentar de } \\
\text { cócoras } \\
\text { (maneira) }\end{array}$ & $\begin{array}{l}\text { Verbo de } \\
\text { posição }\end{array}$ & $\begin{array}{c}\text { Martins } \\
(2004)\end{array}$ & Atonal \\
\hline 600 & /cãk xa/ & çãk xa & $\begin{array}{l}\text { Sentar-se } \\
\text { com força } \\
\text { (maneira) }\end{array}$ & $\begin{array}{l}\text { Verbo de } \\
\text { posição }\end{array}$ & $\begin{array}{c}\text { Martins } \\
\text { (2004) }\end{array}$ & Atonal \\
\hline 601 & /he xa/ & re xa & $\begin{array}{l}\text { Sentar em } \\
\text { cima de }\end{array}$ & $\begin{array}{l}\text { Verbo de } \\
\text { posição }\end{array}$ & $\begin{array}{c}\text { Martins } \\
\text { (2004) }\end{array}$ & Atonal \\
\hline
\end{tabular}




\begin{tabular}{|c|c|c|c|c|c|c|}
\hline & & & $\begin{array}{c}\text { alguma } \\
\text { coisa } \\
\text { (local) } \\
\end{array}$ & & & \\
\hline 602 & / $\mathrm{fa} \mathrm{xa} /$ & sa xa & $\begin{array}{c}\text { Sentar por } \\
\text { longo } \\
\text { tempo } \\
\text { (duração) }\end{array}$ & $\begin{array}{l}\text { Verbo de } \\
\text { posição }\end{array}$ & $\begin{array}{c}\text { Martins } \\
(2004)\end{array}$ & Atonal \\
\hline 603 & /pэx/ & pox & Estar alto & $\begin{array}{l}\text { Verbo de } \\
\text { posição }\end{array}$ & $\begin{array}{c}\text { Martins } \\
(2004) \\
\end{array}$ & Atonal \\
\hline 604 & /hû́t/ & rũut & Soprar & $\begin{array}{l}\text { Verbo de } \\
\text { posição }\end{array}$ & $\begin{array}{l}\text { Martins } \\
(2004)\end{array}$ & Descendente \\
\hline 605 & /nĩ xrd/ & nĩ xâd & $\begin{array}{c}\text { Ficar por aí } \\
\text { andando de } \\
\text { um lado } \\
\text { para outro }\end{array}$ & Verbo serial & $\begin{array}{c}\text { Martins } \\
\text { (2004) }\end{array}$ & Atonal \\
\hline 606 & /xó?/ & xôo' & Circular & Verbo Estativo & $\begin{array}{c}\text { Martins } \\
(2004)\end{array}$ & Ascendente \\
\hline 607 & /nĩ xó?/ & nĩ xôo' & $\begin{array}{c}\text { Estar } \\
\text { circulando }\end{array}$ & Verbo serial & $\begin{array}{l}\text { Martins } \\
(2004)\end{array}$ & Ascendente \\
\hline 608 & $/ \mathrm{h} \varepsilon /$ & $\mathrm{re}$ & $\begin{array}{c}\text { Ser } \\
\text { curvado } \\
\text { para trás }\end{array}$ & Verbo Estativo & $\begin{array}{c}\text { Martins } \\
\text { (2004) }\end{array}$ & Atonal \\
\hline 609 & /dej?/ & dêy' & Ser torto & Verbo Estativo & $\begin{array}{c}\text { Martins } \\
(2004)\end{array}$ & Atonal \\
\hline 610 & / $/$ ã?ã/ & sã'ã & Provar & Verbo Ativo & $\begin{array}{c}\text { Martins } \\
(2004)\end{array}$ & Atonal \\
\hline 611 & /kafãm/ & kasãm & Morrer & Verbo Ativo & $\begin{array}{l}\text { Martins } \\
(2004)\end{array}$ & Atonal \\
\hline 612 & /bcj/ & bey & Repetir & Verbo Ativo & $\begin{array}{c}\text { Martins } \\
(2004)\end{array}$ & Atonal \\
\hline 613 & /n?ũp/ & $n^{\prime} \tilde{u} p$ & Sumir & Verbo Ativo & $\begin{array}{c}\text { Martins } \\
(2004) \\
\end{array}$ & Atonal \\
\hline 614 & /bih/ & bir & $\begin{array}{c}\text { Experiment } \\
\text { ar }\end{array}$ & Verbo Ativo & $\begin{array}{c}\text { Martins } \\
(2004) \\
\end{array}$ & Atonal \\
\hline 615 & /nĩ/ & nĩ & Morar & Verbo Ativo & $\begin{array}{l}\text { Martins } \\
(2004)\end{array}$ & Atonal \\
\hline 616 & /pغ̀m/ & peem & Sentar & Verbo Ativo & $\begin{array}{c}\text { Martins } \\
(2004)\end{array}$ & Descendente \\
\hline 617 & /wàn/ & waan & Ir no rastro & Verbo estativo & $\begin{array}{l}\text { Martins } \\
(2004)\end{array}$ & Descendente \\
\hline 618 & /láj²/ & laay' & Pescar & Verbo Ativo & $\begin{array}{c}\text { Martins } \\
(2004)\end{array}$ & Ascendente \\
\hline 619 & /de/ & dê & $\begin{array}{l}\text { Pescar no } \\
\text { igarapé }\end{array}$ & $\begin{array}{c}\text { Não } \\
\text { classificado por } \\
\text { Martins }\end{array}$ & $\begin{array}{l}\text { Martins } \\
(2004)\end{array}$ & Ascendente \\
\hline 620 & /Rũ̃m/ & 'ũum & Cacetar & Verbo Ativo & $\begin{array}{c}\text { Martins } \\
(2004)\end{array}$ & Descendente \\
\hline 621 & /kip/ & king & Flechar & Verbo Ativo & $\begin{array}{c}\text { Martins } \\
\text { (2004) }\end{array}$ & Atonal \\
\hline 622 & /ta?/ & ta' & Distanciar & Verbo Ativo & $\begin{array}{l}\text { Martins } \\
(2004)\end{array}$ & Atonal \\
\hline 623 & /hũ?/ & rũ' & Acabar & Verbo Ativo & $\begin{array}{l}\text { Martins } \\
(2004)\end{array}$ & Atonal \\
\hline
\end{tabular}




\begin{tabular}{|c|c|c|c|c|c|c|}
\hline 624 & $/ \mathrm{trg} /$ & tâg & Conhecer & Verbo Ativo & $\begin{array}{l}\text { Martins } \\
(2004)\end{array}$ & Atonal \\
\hline 625 & /jow/ & yow & $\begin{array}{c}\text { Ser } \\
\text { reto/atalha } \\
\text { r }\end{array}$ & Verbo Ativo & $\begin{array}{l}\text { Martins } \\
(2004)\end{array}$ & Atonal \\
\hline 626 & /xòj/ & xôoy & Pelar & Verbo Ativo & $\begin{array}{l}\text { Martins } \\
(2004)\end{array}$ & Descendente \\
\hline 627 & $/ \mathrm{t} \tilde{\varepsilon} \mathrm{t} /$ & tẽet & Tremer & Verbo Ativo & $\begin{array}{l}\text { Martins } \\
(2004)\end{array}$ & Ascendente \\
\hline 628 & /jùd/ & yuud & Amolecer & Verbo Ativo & $\begin{array}{c}\text { Martins } \\
(2004)\end{array}$ & Descendente \\
\hline 629 & /nã/ & nã & Voar & Verbo Ativo & $\begin{array}{c}\text { Martins } \\
(2004)\end{array}$ & Atonal \\
\hline 630 & /wá?/ & waa' & Moquear & Verbo Ativo & $\begin{array}{l}\text { Martins } \\
(2004) \\
\end{array}$ & Ascendente \\
\hline 631 & /dél/ & dêel & Conseguir & Verbo Ativo & $\begin{array}{c}\text { Martins } \\
(2004)\end{array}$ & Ascendente \\
\hline 632 & /kaf/ & kas & Ser ruim & Verbo Ativo & $\begin{array}{c}\text { Martins } \\
(2004)\end{array}$ & Atonal \\
\hline 633 & /kũm/ & kũm & Afogar & Verbo Ativo & $\begin{array}{c}\text { Martins } \\
(2004)\end{array}$ & Atonal \\
\hline 634 & /hŕk/ & râk & Afogar & $\begin{array}{c}\text { Não } \\
\text { classificado por } \\
\text { Martins }\end{array}$ & $\begin{array}{l}\text { Martins } \\
(2004)\end{array}$ & Ascendente \\
\hline 635 & /jáh/ & y'aar & Mentir & Verbo Ativo & $\begin{array}{l}\text { Martins } \\
(2004) \\
\end{array}$ & Ascendente \\
\hline 636 & /be?/ & bê' & Ser duro & Verbo estativo & $\begin{array}{c}\text { Martins } \\
(2004)\end{array}$ & Atonal \\
\hline 637 & /né:p/ & nêep & $\begin{array}{c}\text { Esfregar } \\
\text { para tirar a } \\
\text { sujeira }\end{array}$ & Verbo Ativo & $\begin{array}{c}\text { Martins } \\
(2004)\end{array}$ & Ascendente \\
\hline 638 & /lán/ & laan & $\begin{array}{c}\text { Fazer } \\
\text { coivara }\end{array}$ & Verbo Ativo & $\begin{array}{c}\text { Martins } \\
(2004)\end{array}$ & Ascendente \\
\hline 639 & /dit/ & dit & Esfolar-se & Verbo Ativo & $\begin{array}{l}\text { Martins } \\
(2004) \\
\end{array}$ & Atonal \\
\hline 640 & $/ / \mathrm{j} /$ & si & Feder & Verbo Ativo & $\begin{array}{c}\text { Martins } \\
(2004)\end{array}$ & Atonal \\
\hline 641 & fid & siid & $\begin{array}{c}\text { Fazer } \\
\text { cócegas }\end{array}$ & Verbo Ativo & $\begin{array}{c}\text { Martins } \\
(2004)\end{array}$ & Descendente \\
\hline 642 & /wam/ & wam & Amolar & Verbo Ativo & $\begin{array}{c}\text { Martins } \\
(2004)\end{array}$ & Atonal \\
\hline 643 & /xכ̃́k/ & xõok & Roncar & Verbo Ativo & $\begin{array}{l}\text { Martins } \\
(2004)\end{array}$ & Ascendente \\
\hline 644 & $/$ law $^{2} /$ & law' & Mastigar & Verbo Ativo & $\begin{array}{l}\text { Martins } \\
(2004)\end{array}$ & Atonal \\
\hline 645 & /pam/ & pam & Socar chão & Verbo Ativo & $\begin{array}{l}\text { Martins } \\
(2004)\end{array}$ & Atonal \\
\hline 646 & $/$ pow $^{?} /$ & pow' & Babuiar & Verbo Ativo & $\begin{array}{l}\text { Martins } \\
(2004) \\
\end{array}$ & Atonal \\
\hline 647 & /prp/ & pâp & Chutar & Verbo Ativo & $\begin{array}{c}\text { Martins } \\
(2004)\end{array}$ & Atonal \\
\hline 648 & $/ \mathrm{kr} /$ & kâj & $\begin{array}{l}\text { Arranhar } \\
\text { com a unha }\end{array}$ & Verbo Ativo & $\begin{array}{c}\text { Martins } \\
(2004) \\
\end{array}$ & Atonal \\
\hline
\end{tabular}




\begin{tabular}{|c|c|c|c|c|c|c|}
\hline 649 & /muif/ & $\mathrm{muj}$ & Molhar & Verbo Ativo & $\begin{array}{l}\text { Martins } \\
(2004)\end{array}$ & Atonal \\
\hline 650 & /cugg/ & ç\#g & Doer & Verbo Ativo & $\begin{array}{l}\text { Martins } \\
(2004)\end{array}$ & Atonal \\
\hline 651 & /lèg/ & leeg & $\begin{array}{c}\text { Derrubar } \\
\text { casa }\end{array}$ & Verbo Ativo & $\begin{array}{l}\text { Martins } \\
(2004)\end{array}$ & Descendente \\
\hline 652 & /Rắx/ & 'ãax & Pedir & Verbo Ativo & $\begin{array}{l}\text { Martins } \\
(2004)\end{array}$ & Ascendente \\
\hline 653 & /co?/ & $\mathrm{co}^{\prime}$ & $\begin{array}{c}\text { Desamarra } \\
\mathrm{r}\end{array}$ & Verbo Ativo & $\begin{array}{l}\text { Martins } \\
(2004)\end{array}$ & Atonal \\
\hline 654 & /pú?/ & puu' & Enterrar & Verbo Ativo & $\begin{array}{l}\text { Martins } \\
(2004)\end{array}$ & Ascendente \\
\hline 655 & /kér/ & kee' $^{\prime}$ & $\begin{array}{l}\text { Ser cheio } \\
\text { de curvas }\end{array}$ & Verbo Estativo & $\begin{array}{l}\text { Martins } \\
(2004)\end{array}$ & Ascendente \\
\hline 656 & & bâay & Arrotar & Intransitivo & $\begin{array}{c}\text { Trabalho } \\
\text { de } \\
\text { Campo II }\end{array}$ & Ascendente \\
\hline 657 & & win & Trabalhar & Intransitivo & $\begin{array}{c}\text { Trabalho } \\
\text { de } \\
\text { Campo II }\end{array}$ & Atonal \\
\hline 658 & & kũm & Afundar & Intransitivo & $\begin{array}{c}\text { Trabalho } \\
\text { de } \\
\text { Campo II }\end{array}$ & Atonal \\
\hline
\end{tabular}




\section{Anexo 2}

\section{Dados coletados nos testes de processos de intransitivização}

\begin{tabular}{|c|c|c|c|c|}
\hline № & Verbo em Dâw & Verbo em PB & Tom & Testes \\
\hline 1 & rõk & Cortar & Atonal & $\begin{array}{l}\text { Tempo } \\
\text { Passiva } \\
\text { Incoativa } \\
\text { Reflexiva } \\
\text { Média } \\
\text { dô }\end{array}$ \\
\hline 2 & Kâs & Morder & Atonal & $\begin{array}{l}\text { Tempo } \\
\text { Passiva } \\
\text { Incoativa } \\
\text { Reflexiva } \\
\text { Média } \\
\text { dô }\end{array}$ \\
\hline 3 & Yũt & Matar & Atonal & $\begin{array}{l}\text { Tempo } \\
\text { Passiva } \\
\text { Incoativa } \\
\text { Reflexiva } \\
\text { Média } \\
\text { dô }\end{array}$ \\
\hline 4 & Wây & Ver & Atonal & $\begin{array}{l}\text { Tempo } \\
\text { Passiva } \\
\text { Incoativa } \\
\text { Reflexiva } \\
\text { Média } \\
\text { dô } \\
\end{array}$ \\
\hline 5 & Mũm & Abraçar & Atonal & $\begin{array}{l}\text { Tempo } \\
\text { Passiva } \\
\text { Incoativa } \\
\text { Reflexiva } \\
\text { Média } \\
\text { dô } \\
\end{array}$ \\
\hline 6 & Çũnh & Beijar & Atonal & $\begin{array}{l}\text { Tempo } \\
\text { Passiva } \\
\text { Incoativa } \\
\text { Reflexiva } \\
\text { Média } \\
\text { dô }\end{array}$ \\
\hline 7 & $\mathrm{Ya}^{\prime}$ & Assar & Atonal & $\begin{array}{l}\text { Tempo } \\
\text { Passiva } \\
\text { Incoativa } \\
\text { Reflexiva } \\
\text { Média } \\
\text { dô }\end{array}$ \\
\hline
\end{tabular}




\begin{tabular}{|c|c|c|c|c|}
\hline 8 & $\mathrm{Xa}$ & Cozinhar & Atonal & $\begin{array}{l}\text { Tempo } \\
\text { Passiva } \\
\text { Incoativa } \\
\text { Reflexiva } \\
\text { Média } \\
\text { dô }\end{array}$ \\
\hline 9 & $\hat{\mathrm{A} g}$ & Beber & Atonal & $\begin{array}{l}\text { Tempo } \\
\text { Passiva } \\
\text { Incoativa } \\
\text { Reflexiva } \\
\text { Média } \\
\text { dô }\end{array}$ \\
\hline 10 & Rê' & Cavar & Atonal & $\begin{array}{l}\text { Tempo } \\
\text { Passiva } \\
\text { Incoativa } \\
\text { Reflexiva } \\
\text { Média } \\
\text { dô }\end{array}$ \\
\hline 11 & Nee & Fazer & Descendente & $\begin{array}{l}\text { Tempo } \\
\text { Passiva } \\
\text { Incoativa } \\
\text { Reflexiva } \\
\text { Média } \\
\text { dô }\end{array}$ \\
\hline 12 & Rõoy & Focar & Descendente & $\begin{array}{l}\text { Tempo } \\
\text { Passiva } \\
\text { Incoativa } \\
\text { Reflexiva } \\
\text { Média } \\
\text { dô }\end{array}$ \\
\hline 13 & '̃uum & Bater (genérico) & Descendente & $\begin{array}{l}\text { Tempo } \\
\text { Passiva } \\
\text { Incoativa } \\
\text { Reflexiva } \\
\text { Média } \\
\text { dô }\end{array}$ \\
\hline 14 & Weed & Comer & Descendente & $\begin{array}{l}\text { Tempo } \\
\text { Passiva } \\
\text { Incoativa } \\
\text { Reflexiva } \\
\text { Média } \\
\text { dô }\end{array}$ \\
\hline 15 & Paar & Saber & Ascendente & $\begin{array}{l}\text { Tempo } \\
\text { Passiva } \\
\text { Incoativa } \\
\text { Reflexiva } \\
\text { Média } \\
\text { dô }\end{array}$ \\
\hline
\end{tabular}


(1) rõk 'cortar'

a) O tukano cortou o porco

Woor rõk torũuy'

Woor tes torũuy'

b) O tukano cortou o papel

(sujeito animado; objeto inanimado)

Woor rõk xapel
*Woor tes xapel

c) O tukano corta o porco

(sujeito animado; objeto animado)

\section{Woor rõk torũuy}

Woor tes torũuy'

d) O tukano corta o papel

(sujeito animado; objeto inanimado)

Woor rõk xapel

*Woor tes xapel

e) O tukano cortará o porco

(sujeito animado; objeto animado)

Woor rõk nã torũuy'

Woor tes nã torũuy'

f) O tukano cortará o papel

(sujeito animado; objeto inanimado)

\section{Woor rõk nã xapel \\ *Woor tes nã xapel}

Eu e o tukano fomos para a mata e matamos um porco. Deixei o porco na casa do tukano e da esposa dele. No dia seguinte, fui à casa do tukano e vi que o porco foi cortado. Quem será que cortou o porco, o tukano ou a esposa dele?

g) O porco foi cortado. 


\section{Tor rõk yed \\ Tor tes yed \\ 'O porco cortou'}

Eu e o tukano fomos para a mata e matamos um porco. Deixei o porco na casa do tukano e da esposa dele e pedi para eles cortarem o porco para dividirmos a carne entre nossos amigos. No dia seguinte, fui à casa do tukano e perguntei ao tukano: 'o porco (já cortou)?

h) O porco (já) cortou

\section{Rõk yutam tor \\ *Tes yutam tor}

Eu e o tukano fomos para a mata. Havia um galho afiado no chão, quando eu e ele passávamos por aquele galho percebi que o tukano se cortou.

i) O tukano se cortou

\section{Woor rõk tirũuy' \\ Woor rõk tirũuy' xup}

Eu e o tukano fomos para a mata e matamos um porco. Deixei o porco na casa do tukano e da esposa dele e pedi para eles cortarem o porco para dividirmos a carne entre nossos amigos. No dia seguinte, fui à casa do tukano e perguntei ao tukano: você conseguiu cortar o porco? O tukano respondeu: 'Eu consegui cortar o porco, Porco corta fácil (rápido), difícil é cortar carne de anta.

j) Porco corta fácil (rápido)

\section{Tor rõk xet}

k) A mulher fez o tukano cortar o porco (com dô e com waay)

Dâw ãy dô rõk woorũuy' tor

(2) Kâs 'morder'

a) O cachorro mordeu o homem branco (passado)

\section{Yam kâs yed buuyũuy' Yam kâs buuyũuy'}


b) O cachorro mordeu o galho (passado)

Yam kâs bee mĩi

Yam kâs yed bee mĩi

c) O cachorro morde o homem branco (presente)

\section{Yam kâs buuyũuy'}

Yam kas yed buuyũuy'

d) O cachorro morde o galho (presente)

Yam kas bee mĩi

Yam kas yed bee mĩi

e) O cachorro morderá (vai morder) o homem branco (futuro)

\section{Yam kâs yed nã buuyũuy' Yam kâs nã buuyũuy'}

f) O cachorro morderá (vai morder) o galho (futuro)

\section{Yam kâs yed nã bee mĩi Yam kâs nã bee mĩi}

Eu levei o homem branco (Wallace) para minha casa. Meu cachorro estava lá e mordeu o homem branco. Quando meu filho chegou em casa viu que o homem branco estava sangrando e me perguntou: 'o que aconteceu com o homem branco?'. Eu respondi: 'o homem branco foi mordido'.

g) O homem branco foi mordido (pelo cachorro)

\section{Buuy kâs yed \\ 'O homem branco mordeu'}

Eu levei o homem branco (Wallace) para minha casa. Meu cachorro estava lá e mordeu o homem branco. Quando meu filho chegou em casa junto com um amigo viu que o homem branco estava sangrando. Ele viu que o nosso cachorro tinha mordido o homem branco e falou para o amigo dele: "o homem branco mordeu". 
h) O homem branco mordeu.

\section{Estrutura não realizada em Dâw}

Eu levei o homem branco (Wallace) para minha casa. Meu cachorro estava lá e mordeu o homem branco. Quando meu filho chegou em casa junto com um amigo viu que o homem branco estava sangrando. Ele viu que o nosso cachorro tinha mordido o homem branco e falou para o amigo dele: "o homem branco se mordeu".

i) O homem branco se mordeu

\section{Buuy kâs tirũuy' \\ Buuy kâs tirũuy' xup \\ *Buuy kâs xup}

Eu estava com os dentes da boca doendo e pedi para minha esposa fazer galeto cozido para mim. Quando fui comer, disse para minha esposa: "Carne de galeto morde fácil, a carne da anta que é difícil de morder.

j) Carne de galeto morde fácil.

\section{Galeto dep kâs xet}

k) A mulher fez o cachorro morder o homem branco (com dô e waay)

Dâw ãy dô kâs buuy-ũuy'

Dâw ãy dô kâs yamũuy' buuyũuy'

(3) Yũt - 'matar'

a) O cachorro matou o rato (passado)

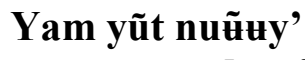

Yam yũt yed nữuy'

b) O cachorro mata o rato

O cachorro está matando o porco espinho (presente)

Yam yũt nu

Yam yũt yed nu

c) O cachorro matará o rato

Yam yũt yed nuñuy'

Yam yũt yed nã nữuy' 
Quando eu cheguei à comunidade, eu vi que o meu cachorro e o cachorro do meu irmão estavam caçando um rato no quintal da minha casa. Entrei em casa para pegar uma vassoura para matar o rato, quando sai de novo, vi que o rato foi morto. Quem será que matou o rato, o meu cachorro ou o cachorro do meu irmão?

d) $\mathrm{O}$ rato foi morto

\section{Nu kasãm \\ 'O rato morreu'}

Quando eu cheguei à comunidade, vi que tinha um rato no meu quintal. Entrei em casa e peguei uma vassoura para matar o rato. Quando voltei, vi que o rato estava parado, encostei nele e ele não se mexeu, então eu pensei: o rato já morreu.

e) O rato já morreu.

\section{Nu kasãm yutam}

Quando eu cheguei na comunidade, me disseram que o filho do meu vizinho estava muito triste e não queria viver mais. No dia seguinte me disseram que o menino se matou, o menino se morreu.

f) O menino se matou.

Dâw tee yũt tirũuy' xup

Dâw tee yũt tirũuy'

Quando eu cheguei à comunidade, vi que tinha um rato no meu quintal. Entrei em casa e peguei uma vassoura para matar o rato. Quando voltei dei uma única vassorada no rato e ele morreu. Em seguida, falei para minha esposa: 'Rato mata fácil, dificil é matar porco.

h) Rato mata fácil

\section{Nũ yũt xet}

i) O homem fez o cachorro matar o rato

Dâw xut dô yũt yamũuy’ nũuty'

(4) Wây 'ver'

a) O homem viu o porco espinho (passado) 


\section{Dâw xut wây pũug}

b) O homem vê o porco espinho (presente)

\section{Dâw xut wây 'wap pũug}

c) O homem verá o porco espinho (futuro)

\section{Dâw xut wây nã pũug}

Eu e três amigos estávamos caçando um porco espinho na mata. Nos dividimos para poder encontrar o porco entre as árvores. Depois de alguns minutos escutei uma voz: 'Achei o porco espinho!'. Logo em seguida falei para o amigo que estava perto de mim: 'o porco espinho foi visto'. Quem será que o viu?

d) O porco espinho foi visto.

\section{Dâw wây pũug}

Eu e três amigos estávamos caçando um porco espinho na mata. Nos dividimos para poder encontrar o porco entre as árvores. Depois de alguns minutos escutei uma voz: 'Achei o porco espinho!'. Logo em seguida falei para o amigo que estava perto de mim: 'o porco espinho já viu'.

e) O porco espinho já viu

\section{Pũug wây yut}

Comprei um espelho para deixar na sala da minha casa. Minha esposa chegou com uma criança em casa e me disse: 'a criança se viu no espelho e não gostou do que viu.

f) A criança se viu (no espelho)

\section{Dâw tee wây tirũuy' (rũy wâk rêd)}

Meus dois filhos fizeram desenhos na escola e levaram para eu ver. Os dois desenharam uma casa. Disse para eles: uma casa vê fácil nesse desenho, nesse outro não.

g) Uma casa vê fácil

\section{Top wâsoer dâw wây}


h) A mulher fez o homem ver o porco espinho (com dô e waay)

Dâw ãy dô wây dâw xutũuy'pũug

(5) Mũm 'abraçar'

a) O homem abraçou a criança (passado)

\section{Dâw xut mũm dâw teeũuy'}

b) O homem abraça a criança (presente)

\section{Dâw xut mũm dâw teeũuy'}

c) O homem abraçará a criança (futuro)

\section{Dâw xut mũm nã dâw teeũuy'}

Dois homens esperavam no porto a chegada de uma criança da cidade. Vi a criança muito feliz com os dois homens e perguntei para minha esposa: 'por que ela está tão feliz?' Minha esposa me respondeu: 'a criança foi abraçada'. Perguntei novamente: 'quem abraçou a criança?

d) A criança foi abraçada

\section{Rid mũm dâw teeũuy'}

Minha esposa viu um homem abraçando uma criança no porto. Quando eu cheguei em casa ela me disse: 'a criança abraçou'.

e) A criança abraçou

\section{Estrutura não realizada em Dâw}

Duas crianças estavam brincando na comunidade. Elas estavam enrolando os braços no pescoço, estava muito engraçado. Uma mulher viu a cena e falou para mim: 'olha, a criança se abraçou'.

f) A criança se abraçou 


\section{Dâw tee mũm tirũuy' \\ Dâw tee mũm tirũuy' xup \\ *Dâw tee mũm xup}

Quando cheguei em casa havia uma criança e um adulto em casa. Quando fui cumprimentar a criança, ela me deu um abraço, o adulto apenas me estendeu a mão. Falei para minha esposa: 'criança abraça fácil, adulta não'.

g) Criança abraça fácil

Dâw tee mũm wâsoer

h) A mulher fez o homem abraçar a criança (com dô e waay)

Dâw ãy dô mũm dâw xutũuy' dâw teeũuy'

(6) Çũnh 'beijar'

a) A mulher beijou a criança (passado)

\section{Dâw ãy çũnh dâw teeũuy'}

b) A mulher beija a criança (Presente)

\section{Dâw ãy çũnh dâw teeũuy'}

c) A mulher beijará a criança (futuro)

\section{Dâw ãy çũnh nã dâw teeũuy'}

Duas mulheres esperavam no porto a chegada de uma criança da cidade. Vi a criança muito feliz com as duas mulheres e perguntei para minha esposa: 'por que a criança está tão feliz?' Minha esposa me respondeu: 'a criança foi beijada'. Perguntei novamente: 'quem beijou a criança?

d) A criança foi beijada

Dâw tee çũnh yed

'A criança beijou' 
Minha esposa viu uma mulher beijando uma criança no porto. Quando eu cheguei em casa ela me disse: 'a criança beijou'.

e) A criança beijou

Dâw tee çũnh yed

'A criança beijou'

Duas crianças estavam brincando na comunidade. Elas estavam beijando suas próprias mãos e braços, estava muito engraçado. Uma mulher viu a cena e falou para mim: 'olha, a criança se beijou'.

f) A criança se beijou

Dâw tee çũnh tirũuy'

Dâw tee çũnh tirũuy' xup

*Dâw tee çũnh xup

Quando cheguei em casa havia uma criança e um adulto em casa. Quando fui

cumprimentar a criança, ela me deu um beijo, o adulto apenas me estendeu a mão. Falei para minha esposa: 'criança beija fácil, adulta não'.

g) Criança beija fácil

Dâw tee çũnh wâsoer

h) O homem fez a mulher beijar a criança (com dô e waay)

Dâw xut dô çũnh dâw ãyũuy' dâw teeũuy'

(7) Ya' 'assar'

a) O homem assou o porco

Dâw xut ya' tor

b) O homem assa o porco

Dâw xut ya' tor

c) O homem assará o porco

Dâw xut ya' nã tor

Eu deixei uma carne de porco na mesa e fui para a cidade. Quando eu voltei vi que o porco foi assado. Quem assou o porco? 
d) O porco foi assado Estrutura não realizada em Dâw

Eu coloquei o porco para assar. Uma hora depois eu liguei para perguntar: o porco já assou?

e) O porco já assou

Tor ya' yutam

Eu coloquei o porco para assar. Uma hora depois eu liguei para perguntar: o porco se assou? Nesse mesmo contexto, é possível dizer o porco se assou?

f) O porco se assou.

\section{Estrutura não realizada em Dâw}

Carne de porco assa rápido, mas carne de macaco demora mais.

g) Carne de porco assa rápido

Tor dep ya' xet

h) A mulher fez o homem assar o porco (com dô e waay)

Dâw ãy dô ya' dâw xutũuy' toe

i) Xa 'cozinhar'

a) O homem cozinhou o feijão (passado)

\section{Dâw xut xa mãam}

b) O homem cozinha o feijão (presente)

Dâw xut xa wê mãam

' $O$ homem sempre cozinha o feijão'

c) O homem cozinhará (vai cozinhar) o feijão (futuro) 


\section{Dâw xut xa nã mãam}

Eu deixei um saco de feijão em cima da mesa e fui para a cidade. Quando eu voltei vi que o feijão foi cozido. Quem cozinhou o feijão?

d) O feijão foi cozido

\section{Mãam xa yutam}

Eu coloquei o feijão para cozinhar. Uma hora depois eu liguei para perguntar: o feijão já cozinhou?

e) O feijão já cozinhou

\section{Mãam xa yutam}

Eu coloquei o feijão para cozinhar. Uma hora depois eu liguei para perguntar: o feijão se cozinhou? Nesse mesmo contexto, é possível dizer o porco se assou?

f) O feijão se cozinhou

\section{Estrutura não realizada em Dâw}

Feijão cozinha rápido, mas carne demora mais.

g) Feijão cozinha rápido

\section{Mãam xa xet}

h) A mulher fez o homem cozinhar o feijão

Dâw ãy dô xa dâw xutũuy' mãam

(9) Âg 'beber'

a) O homem bebeu o caxiri (passado)

Dâw xut âg âg 
b) O homem bebe o caxiri (presente)

\section{Dâw xut âg âg}

c) O homem beberá (vai beber) o caxiri (futuro)

\section{Dâw xut âg na âg}

Eu deixei caxiri em cima da mesa e sai. Quando voltei, eu vi que o caxiri foi bebido. Quem bebeu o caxiri?

d) O caxiri foi bebido

\section{Âg âg yed}

Eu deixei caxiri em cima da mesa e sai. Quando voltei, eu vi que o caxiri já bebeu. Quem bebeu o caxiri?

e) O caxiri já bebeu

\section{Estrutura não realizada em Dâw}

Eu deixei caxiri em cima da mesa da cozinha e fui no quintal. Quando voltei, não tinha mais caxiri. Só eu e o meu filho estávamos em casa. Eu perguntei para o meu filho: você bebeu o caxiri? - Não. - O caxiri se bebeu?'

f) O caxiri se bebeu

\section{Estrutura não realizada em Dâw}

Caxiri bebe fácil, difícil é beber vinho de açaí.

g) Caxiri bebe fácil

\section{Âg âg xet}

h) A mulher fez o homem beber o caxiri (com dô e waay)

Dâw ãy dô âg dâw xutũuy' âg 
(10)

$$
\text { Rê' 'cavar' }
$$

a) O homem cavou um buraco (passado)

\section{Dâw xut kon mãy}

b) O homem cava um buraco (presente)

\section{Dâw xut kon mãy}

c) O homem cavará um buraco (futuro)

\section{Dâw xut kon nã mãy}

Eu sai para trabalhar e pedi para meu filho cavar um buraco para fazer um poço. Assim que cheguei no porto, meu filho me falou que não teve tempo de cavar o buraco. Quando cheguei em casa vi que o buraco foi cavado. Quem cavou o buraco?

d) O buraco foi cavado

\section{Estrutura não realizada em Dâw}

Eu sai para trabalhar e pedi para meu filho cavar um buraco para fazer um poço. Quando cheguei em casa vi que o buraco já cavou.

e) O buraco já cavou

\section{Estrutura não realizada em Dâw}

Eu sai para trabalhar e pedi para meu filho cavar um buraco para fazer um poço. Assim que cheguei no porto, meu filho me falou que não teve tempo de cavar o buraco. Quando cheguei em casa vi que havia um buraco no meu quintal. Perguntei para todos: 'Quem cavou o buraco?' Todos responderam: 'ninguém'. Perguntei novamente: 'o buraco se cavou, então?

f) O buraco se cavou

\section{Estrutura não realizada em Dâw}

Eu sai para trabalhar e pedi para meu filho cavar um buraco para fazer um poço. Assim que cheguei perguntei ao meu filho se ele havia cavado o buraco. Ele me respondeu: 'cavar buraco é fácil, difícil é fazer o poço'. 
g) Cavar buraco é fácil.

Mãy kon xet

h) A mulher fez o homem cavar um buraco.

Dâw ãy dô kon dâw xutũuy'

(11) Nee 'fazer'

a) O homem fez um colar (passado)

Dâw xut nee ked rẽ

b) O homem faz colar (presente)

\section{Dâw xut nee ked rẽ}

c) O homem fará colar (futuro)

\section{Dâw xut nee nã ked rẽ}

Eu sai para trabalhar e pedi para meu filho fazer um belo colar para mim. Assim que cheguei ao porto, meu filho me falou que não teve tempo de fazer o colar. Quando cheguei em casa vi que o colar foi feito. Quem fez o colar?

d) O colar foi feito

\section{Estrutura não realizada em Dâw}

Eu sai para trabalhar e pedi para meu filho fazer um belo colar para mim. Quando cheguei em casa vi que o colar já fez.

e) O colar já fez

\section{Ked rẽ nee yutam}

Eu sai para trabalhar e pedi para meu filho fazer um colar. Assim que cheguei ao porto, meu filho me falou que não teve tempo de fazer o colar. Quando cheguei em casa vi que havia um colar pronto. Perguntei para todos: 'Quem fez o colar?' Todos responderam: 'ninguém'. Perguntei novamente: 'o colar se fez, então? 
f) O colar se fez

\section{Estrutura não realizada em Dâw}

Eu sai para trabalhar e pedi para meu filho fazer um colar. Assim que cheguei perguntei ao meu filho se ele havia feito o colar. Ele me respondeu: 'colar faz fácil, difícil é fazer uma casa'.

g) Colar faz fácil

Ked rẽ nee xet

h) A mulher fez o homem fazer um artesanato (com dô e waay)

Dâw ãy dô nee dâw xutũuy' ked re

$$
\text { Rõoy 'focar' }
$$

a) O homem focou o porco espinho (passado)

\section{Dâw xut rõoy pũug}

b) O homem foca o porco espinho (presente)

\section{Dâw xut rõoy pũugũuy'}

c) O homem focará o porco espinho (futuro)

\section{Dâw xut rõoy nã pũugũuy'}

Eu estava na mata caçando um porco espinho, mas estava muito escuro. Vi que dois homens com uma lanterna estavam se aproximando. Pedi para eles: 'foquem o porco para mim!". Vi que o porco espinho foi focado, mas não sei qual dos dois homens focou o porco espinho.

d) O porco espinho foi focado

\section{Estrutura não realizada em Dâw}

Eu estava na mata caçando um porco espinho, mas estava muito escuro. De repente o porco focou, mas não sei como. 
e) O porco espinho focou

\section{Estrutura não realizada em Dâw}

Eu estava na mata caçando um porco espinho, mas estava muito escuro. De repente o porco se focou sozinho.

f) O porco espinho se focou

Estrutura não realizada em Dâw

Eu estava na mata caçando um porco espinho, mas estava muito escuro. Vi que dois homens com uma lanterna estavam se aproximando. Pedi para eles: 'foquem o porco para mim!' Um deles me respondeu: 'porco espinho foca fácil, difícil é focar uma onça'.

g) Porco espinho foca fácil

Pũug rõoy xet

h) A criança fez o homem focar o porco espinho (com dô e waay)

Dâw tee dô rõoy dâw xutũuy' pũugũuy'

(13) 'ũum 'bater'

a) O homem bateu na criança (passado)

Dâw xut 'ũum dâw teeũuy'

b) O homem bate na criança (presente)

Dâw xut 'ũum dâw teeũuy'

c) O homem baterá (vai bater) na criança (futuro)

Dâw xut 'ũum nã dâw teeũuy' 
Vi dois homens levando uma criança para o porto. A criança voltou chorando. Perguntei para minha esposa: o que aconteceu com a criança?' Minha esposa respondeu: 'a criança foi batida'. Quem bateu na criança?

d) A criança foi batida

\section{Estrutura não realizada em Dâw}

Vi uma criança brincando com um pau. Em seguida ela começou a chorar muito. Perguntei para minha esposa: 'o que aconteceu com a criança?' Ela respondeu: 'a criança bateu com o pau'.

e) A criança bateu

\section{Estrutura não realizada em Dâw}

Vi uma criança brincando com um pau. Em seguida ela começou a chorar muito. Perguntei para minha esposa: 'o que aconteceu com a criança?' Ela respondeu: 'a criança se bateu com o pau'.

f) A criança se bateu

\section{Dâw tee 'ũum tirũuy'}

Meu filho foi malcriado comigo e bati nele. Falei para minha mulher: 'criança bate fácil, difícil é bater em adulto'.

g) Criança bate fácil

\section{Dâw tee 'ũum xet}

h) A mulher fez o homem bater na criança (com dô e waay)

\section{Dâw ãy dô 'ũum dâw xutũuy' dâw teeũuy’}

(14) Weed 'comer'

a) O homem comeu beiju (passado)

\section{Dâw xut weed baa'}

b) O homem come beiju (presente) 


\section{Dâw xut weed baa'}

c) O homem comerá (vai comer) beiju (futuro)

\section{Dâw xut weed nã baa'}

Eu deixei beiju em cima da mesa e sai. Quando voltei, eu vi que o beiju foi comido. Quem comeu o beiju?

d) O beiju foi comido

\section{Estrutura não realizada em Dâw}

Eu deixei beiju em cima da mesa e sai. Quando voltei, eu vi que o beiju já comeu.

e) O beiju já comeu

\section{Estrutura não realizada em Dâw}

Eu deixei beiju em cima da mesa da cozinha e fui no quintal. Quando voltei, não tinha mais beiju. Só eu e o meu filho estávamos em casa. Eu perguntei para o meu filho: você comeu o beiju?- Não. - O beiju se comeu?'

f) O beiju se comeu

\section{Estrutura não realizada em Dâw}

Carne de frango come fácil, mas carne de anta é difícil

g) Carne de frango come fácil

Galeto dep weed xet

h) A mulher fez o homem comer o beiju (com dô e waay)

Dâw ãy dô weed dâw xutũuy' baa'

$$
\text { Paar 'saber' }
$$

a) O homem soube a lenda (passado)

\section{Dâw xut paar história}


b) O homem sabe a lenda (presente)

\section{Dâw xut paar historia}

c) O homem saberá a lenda (futuro)

\section{Dâw xut paar nã história}

Perguntei para as crianças da comunidade se eles sabiam a lenda da origem dos Dâw. Eles me disseram que não e prometi a eles que contaria depois. No dia seguinte alguém me falou que uma criança sabia a lenda muito bem, pensei: 'a lenda foi sabida'. Quem soube da lenda?

d) A lenda foi sabida

\section{Tir paar história}

Perguntei para as crianças da comunidade se eles sabiam a lenda da origem dos Dâw. Eles me disseram que não e prometi a eles que contaria depois. No dia seguinte alguém me falou que só se falada sobre a lenda. Pensei: 'a lenda já soube'.

e) A lenda já soube

\section{Rid paar yutam história}

Perguntei para as crianças da comunidade se eles sabiam a lenda da origem dos Dâw. Eles me disseram que não e prometi a eles que contaria depois. No dia seguinte alguém me falou que só se falada sobre a lenda. Pensei: 'a lenda se soube'.

f) A lenda se soube

\section{Rid paar mĩi história}

Perguntei para as crianças da comunidade se eles sabiam a lenda da origem dos Dâw. Eles me disseram que não. Falei para eles: 'a lenda da origem dos Dâw sabe fácil, difícil é sobre a origem dos yuhup.

g) A história sabe fácil

\section{Estrutura não realizada em Dâw}

h) O homem fez a criança saber a lenda (com dô e waay)

Dâw xut paar waay dâw teeũuy' história

Dâw xut dô paar dâw teeũuy' história 
Sentenças produzidas pelos informantes $V, S$ e $P$ na elicitação com colocação de figuras e explanação de ações.

- Informante V

1. Ãr tuk Jéssica-ũuy'

1PS querer Jéssica-MDO

'Eu quero a Jéssica'

2. Ãr tuk Wallace-ũuy,

1PS querer Wallace-MDO

'Eu quero o Wallace'

3. ̃̃r tuk dâw xut-ũuy'

1PS querer gente macho-MDO

'Eu quero o homem'

4. Ãr tuk dâw ãy-ũuy'

1PS querer gente fêmea-MDO

'Eu quero a mulher'

5. Ãr tuk Wallace-ũuy'

1PS querer Wallace-MDO

'Eu quero o Wallace'

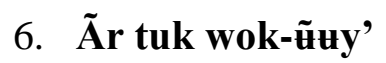

1PS querer tatu-MDO

'Eu quero o tatu"

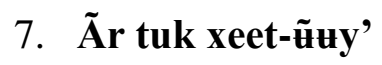

1PS querer jacaré-MDO

'Eu quero o jacaré'

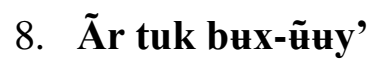

1PS querer morcego-MDO

'Eu quero o morcego'

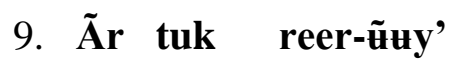

1PS querer cobra-MDO 
'Eu quero a cobra'

10. Ãr tuk wok-ũuy'

1PS querer tatu-MDO

'Eu quero o tatu"

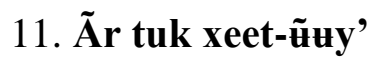

1PS querer jacaré-MDO

'Eu quero o jacaré'

12. Ãr tuk waas-ũuy'

1PS querer macaco-MDO

'Eu quero o macaco'

13. Ãr tuk wok-ũuy'

1PS querer tatu-MDO

'Eu quero o tatu"

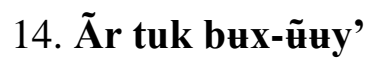

1PS querer morcego-MDO

'Eu quero o morcego'

15. Ãr tuk colar-ũuy,

1PS querer colar-MDO

'Eu quero o colar'

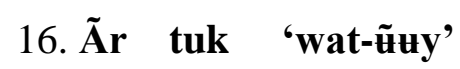

1PS querer milho-MDO

'Eu quero o milho'

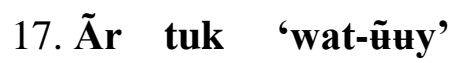

1PS querer milho-MDO

'Eu quero o milho'

18. Ãr tuk yeg-ũuy'

1PS querer rede-MDO

'Eu quero a rede'

19. Ãr tuk yooy

1PS querer fruta

'Eu quero fruta'

20. Ãr tuk yun

1PS querer roupa 
'Eu quero a roupa'

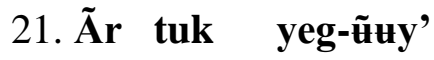

1PS querer rede-MDO

'Eu quero a rede'

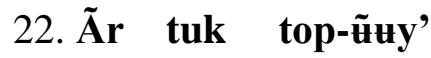

1PS querer casa-MDO

'Eu quero a casa'

23. Âr tuk taax uy-ũuy'

1PS querer anta ?-MDO

'Eu quero a anta'

24. Âr tuk yam-ũuy'

1PS querer onça-MDO

'Eu quero a onça'

- Informante S

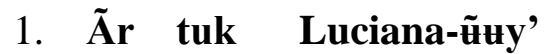

1PS querer Luciana-MDO

'Eu quero a Luciana'

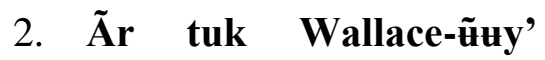

1PS querer Wallace-MDO

'Eu quero o Wallace'

3. Ãr tuk dâw xut-ũuy'

1PS querer gente macho-MDO

'Eu quero o homem'

4. Ãr tuk dâw ãy-ũuy'

1PS querer gente fêmea-MDO

'Eu quero a mulher'

5. Ãr tuk Luciana-ũuy,

1PS querer Luciana-MDO

'Eu quero a Luciana'

6. Ãr tuk yâw-ĩuy'

1PS querer tatu-MDO 
'Eu quero o tatu'

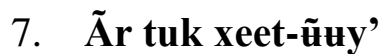

1PS querer jacaré-MDO

'Eu quero o jacaré'

8. Ãr tuk taax-ũuy'

1PS querer anta-MDO

'Eu quero a anta'

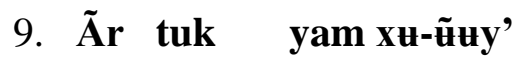

1PS querer onça-MDO

'Eu quero a onça'

10. Ãr tuk yâw

1PS querer tatu

'Eu quero o tatu"

11. Ãr tuk xeet

1PS querer jacaré

'Eu quero o jacaré'

12. Ãr tuk waas-ũuy'

1PS querer macaco-MDO

'Eu quero o macaco'

13. Âr tuk yâw-ũuy

1PS querer tatu-MDO

'Eu quero o tatu"

14. Ãr tuk xeet-ũuy'

1PS querer jacaré-MDO

'Eu quero o jacaré'

15. Ãr tuk ked rẽ

1PS querer colar

'Eu quero o colar'

16. Âr tuk yooy-ũuy'

1PS querer fruta-MDO

'Eu quero fruta'

17. Ãr tuk yak a'

1PS querer macaxeira 
'Eu quero macaxeira'

18. Âr tuk yeg

1PS querer rede

'Eu quero a rede'

19. Ãr tuk yooy

1PS querer fruta

'Eu quero fruta'

20. Ãr tuk yun

1PS querer roupa

'Eu quero a roupa'

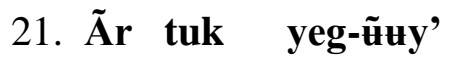

1PS querer rede-MDO

'Eu quero a rede'

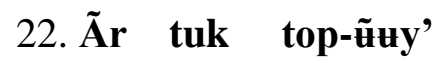

1PS querer casa-MDO

'Eu quero a casa'

23. Ãr tuk ked rẽ-ũuy'

1PS querer colar-MDO

'Eu quero o colar'

24. Ãr tuk Jéssica-ũuy'

1PS querer Jéssica-MDO

'Eu quero a Jéssica'

- Informante P

1. ̃̃r tuk Luciana-ũuy'

1PS querer Luciana-MDO

'Eu quero a Luciana'

2. Ãr tuk Wallace-ũuy'

1PS querer Wallace-MDO

'Eu quero o Wallace'

3. Ãr tuk Luciana-ũuy'

1PS querer Luciana-MDO 
'Eu quero a Luciana'

4. Ãr tuk dâw ãy-ũuy' 1PS querer gente fêmea-MDO

'Eu quero a mulher'

5. Ãr tuk Wallace-ũuy' 1PS querer Wallace-MDO 'Eu quero o Wallace'

6. Ãr tuk sãas 1PS querer tatu 'Eu quero o tatu'

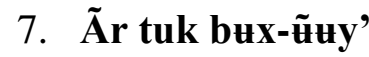
1PS querer morcego-MDO 'Eu quero o morcego'

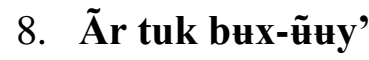
1PS querer morcego-MDO 'Eu quero o morcego'

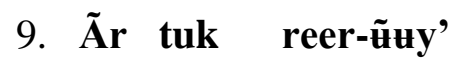
1PS querer cobra-MDO 'Eu quero a cobra'

10. Ãr tuk waas-ũuy' 1PS querer macaco-MDO 'Eu quero o macaco'

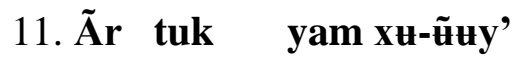
1PS querer onça-MDO 'Eu quero a onça'

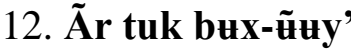

1PS querer morcego-MDO

'Eu quero o morcego'

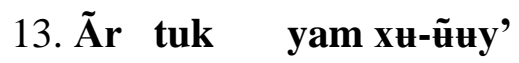
1PS querer onça-MDO

'Eu quero a onça'

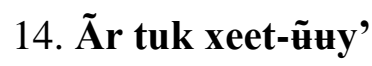

1PS querer jacaré-MDO 
'Eu quero o jacaré'

15. Âr tuk xuy lôor

1PS querer brinco

'Eu quero o brinco'

16. Ãr tuk yooy

1PS querer fruta

'Eu quero fruta'

17. Âr tuk yak a' 1PS querer macaxeira

'Eu quero macaxeira'

18. Âr tuk yeg-ũuy'

1PS querer rede-MDO

'Eu quero a rede'

19. Ãr tuk yooy-ũuy'

1PS querer fruta-MDO

'Eu quero fruta'

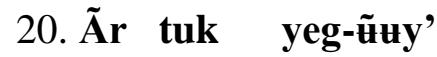

1PS querer rede-MDO

'Eu quero a rede'

21. Ãr tuk yeg

1PS querer rede

'Eu quero a rede'

22. Ãr tuk top

1PS querer casa

'Eu quero a casa'

23. Ãr tuk ked rẽ

1PS querer colar

'Eu quero o colar'

24. Âr tuk Jéssica-ũuy'

1PS querer Jéssica-MDO

'Eu quero a Jéssica' 